WHC-EP-0466-1

Revision 1

UC- 9002

\title{
Facility Effluent Monitoring Plan for 242-A Evaporator Facility
}

\author{
G. M. Crummel \\ R. D. Gustavson
}

Date Published

March 1993

Prepared for the U.S. Department of Energy

Funding Source

\section{(2.) Westinghouse \\ P.O. Box 1970 \\ Hanford Company Richland, Washington 99352}

Hanford Operations and Engineering Contractor for the

U.S. Department of Energy under Contract DE-AC06-87RL10930

Approved for Public Release 


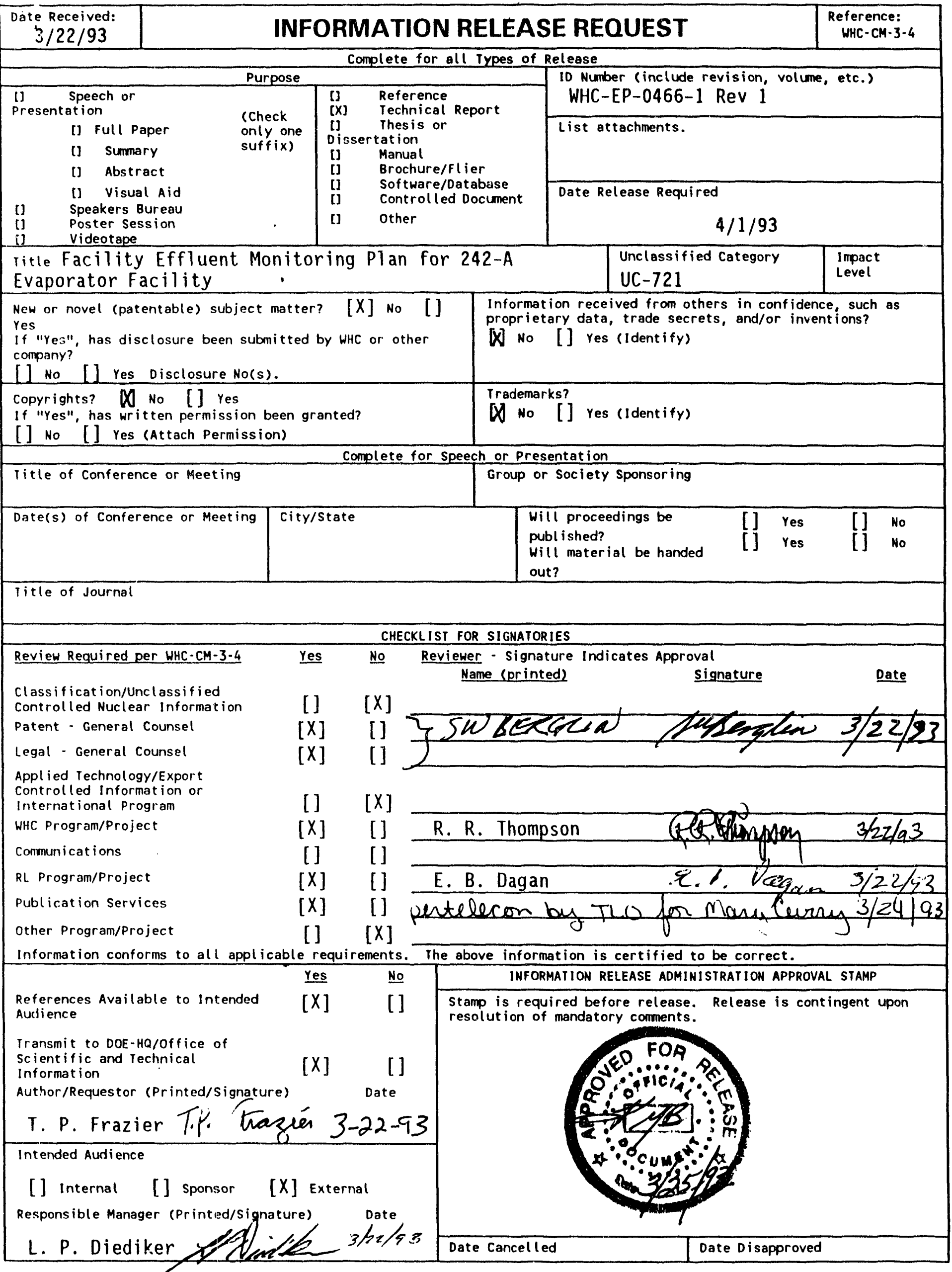




$$
\text { WHC-EP-0466-1 }
$$

Document Title: Facility Effluent Monitoring Plan for the 242-A Evaporator Facility

Prepared by:

Prepared by:

Approved by:

Approved by:

Approved by:

Approved by:

Approved by:

Approved by:

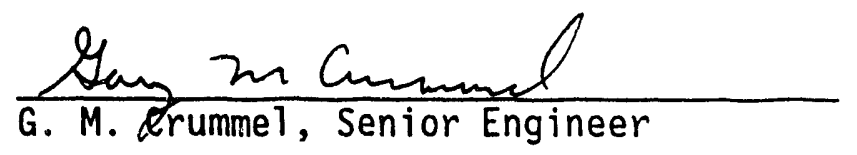

R.D. Gustarsm

R. D. Gustavson, Advanced Engineer

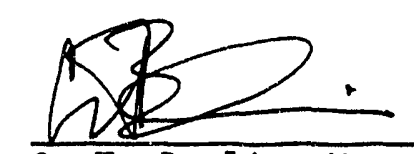

G. T. Berlin, Manager Tank Farms Environmental Engineering

O. -G. Hamrick, Manager

Facility Operations
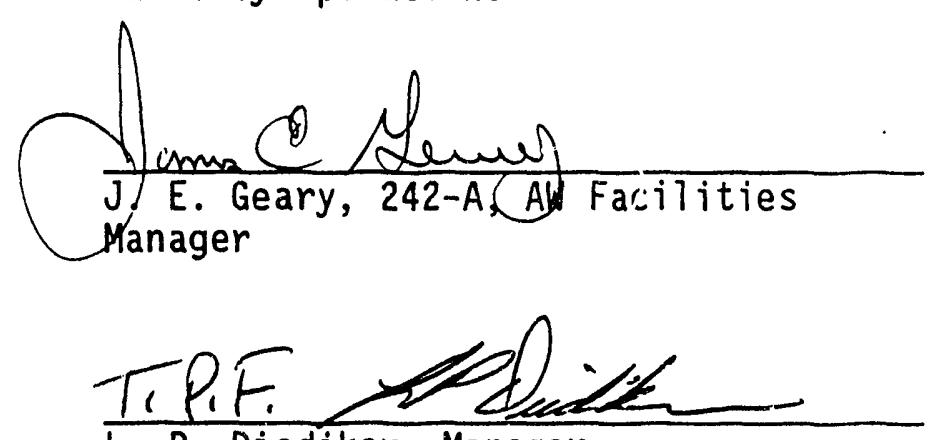

L.P. Diediker, Manager

Effluent and Emission Monitoring

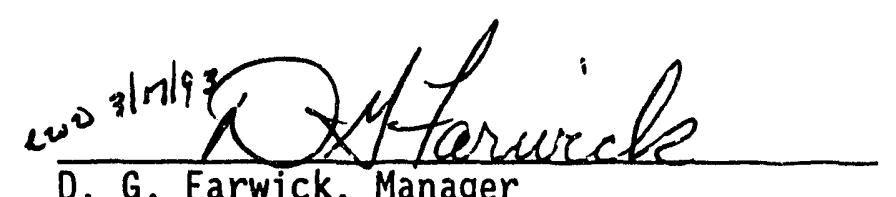

D. G. Farwick, Manager

Environmental Services Quality Assurance

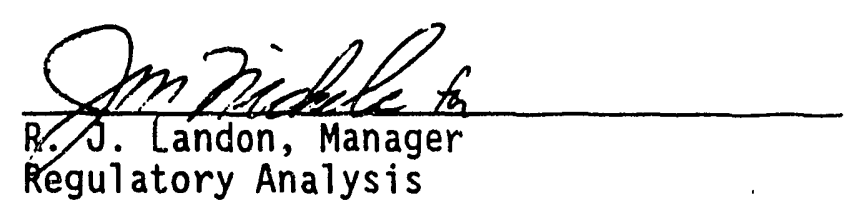

$\frac{2 / 22 / 93}{\text { Date }}$

$\frac{2 / 22 / 93}{\text { Date }}$

$\frac{2 / 22 / 93}{\text { Date }}$

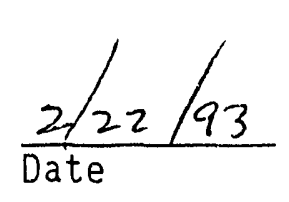

$\frac{2 / 22 / 93}{\text { Date }}$

$\frac{3-16-93}{\text { Date }}$

$\frac{3 / 17 / 93}{\text { Date }}$

$\frac{2 / 26 / 93}{\text { Date }}$

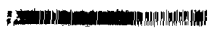


WHC-EP-0466-1

\title{
FACILITY EFFLUENT MONITORING PLAN FOR THE 242-A EVAPORATOR FACILITY
}

\section{J. M. Nickeis}

\begin{abstract}
A facility effluent monitoring plan is required by the U.S. Department of Energy in DOE Order 5400.1* for any operations that involve hazardous materials and radioactive substances that could affect employee or public safety or the environment. A facility effluent monitoring plan determination was performed during Calendar Year 1991 and the evaluation showed the need for a facility effluent monitoring plan. This document is prepared using the specific guidelines identified in A Guide for Preparing Hanford Site Facility Effluent Monitoring Plans, WHC-EP-0438-1**. This facility effluent monitoring plan assesses effluent monitoring systems and evaluates whether they are adequate to ensure the public health and safety as specified in applicable federal, state, and local requirements.
\end{abstract}

This facility effluent monitoring plan shall ensure long-range integrity of the effluent monitoring systems by requiring an update whenever a new process or operation introduces new hazardous materials or significant radioactive materials. This document must be reviewed annually even if there are no operational changes, and it must be updated, as a minimum, every three years.

*General Environmental Protection Program, DOE Order 5400.1, U.S. Department of Energy, Washington, D.C., 1988.

**A Guide for Preparing Hanford Site Facility Effluent Monitoring Plans, WHC-EP-0438-1, Westinghouse Hanford Company, Richland, Washington, 1992. 
This facility effluent monitoring plan has been revised to include U.S. Department of Energy/Westinghouse Hanford Company Regulatory Analysis comments, procedure changes (revisions), and improved U.S. Environmental Protection Agency "National Emission Standards for Hazardous Air Pollutants"* point-by-point evaluation.

* "National Emission Standards for Hazardous Air Pollutants" (NESHAP), Title 40, Code of Federal Regulations, Part 61, as amended, U.S. Environmental Protection Agency, Washington, D.C., 1987. 


\section{CONTENTS}

1.0 FACILITY EFFLUENT MONITORING PLAN . . . . . . . . . . . 1-1

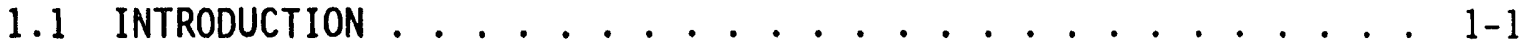

1.1 .1 Policy . . . . . . . . . . . . . . . . . 1-1

1.1 .2 Purpose ................. . . 1-1

1.1 .3 Scope ................... . . 1-1

1.1 .4 Discussion ............... 1-2

2.0 FACILITY DESCRIPTION ..................... 2-1

2.1 FACILITY PHYSICAL DESCRIPTION ........... . 2-1

2.2 PROCESS DESCRIPTION $\ldots . . . . .2-8$

2.3 IDENTIFICATION AND CHARACTERIZATION OF POTENTIAL

SOURCE TERMS ...................... . . . . . . .

2.3.1 Background Information ............ 2-11

2.3.2 Evaporator Feed Types . . . . . . . . . . 2-12

2.3.3 Evaporator Radiological Potential Source Terms . . . . 2-14

2.3.4 Evaporator Nonradiological Potential Source Terms . . . 2-16

2.3.5 Process Condensate Nonradiological Potential

Source Terms . . . . . . . . 2-28

2.3.6 Process Condensate Radiological Potential

Source Terms ......... . . . 2-39

3.0 APPLICABLE REGULATIONS .................. . . . . . . .

3.1 REGULATIONS ......................

3.1.1 Protection of the Public and the Environment . . . . 3-1

3.2 REGULATIONS PERTAINING TO MONITORING REQUIREMENTS AT

3.2.1 U.S. Department of Energy Facility Effiuent $2 . . . .3-5$

3.2.2 Airborne Effluents. . . . . . . . . . . . . . 3-7

3.2.3 Liquid Effluents ............... . . 3-9

3.2.4 Hazardous Mixed Wastes . . . . . . . . . . . . . 3-11

3.3 STANDARDS/REFERENCES ............... . . . . . . . .

3.4 WESTINGHOUSE HANFORD COMPANY EFFLUENT MONITORING

REQUIREMENTS . . . . . . . . 3-11

3.5 FACILITY REQUIREMENTS FOR ORGANIC EMISSION STANDARDS . . . . . 3-12

4.0 IDENTIFICATION AND CHARACTERIZATION OF EFFLUENT STREAMS . . . . . . 4-1

4.1 FACILITY EFFLUENT STREAMS . . . . . . . . . . . . . 4-1

4.1.1 Gaseous Streams ................. . 4-1

4.1 .2 Liquid Effluent Streams . . . . . . . . . . . 4-5

4.1.3 242-A Building Sol id Waste . . . . . . . . 4-16

4.2 IDENTIFICATION AND CHARACTERIZATION OF SOURCE TERMS

CONTRIBUTING TO EACH EFFLUENT STREAM . . . . . . . . . 4-16

4.2.1 Rout ine Operating Conditions .......... . . 4-17

4.2.2 Upset Operating Conditions . . . . . . . . . . . . . . 4-29

5.0 EFFLUENT POINT OF DISCHARGE DESCRIPTION . . . . . . . . . . 5-1

5.1 GASEOUS EFFLUENT STREAMS ............... 5-

5.1 .1 Vessel Ventilation System ............. 5-1

5.1.2 Building Ventilation System ........... 5-7 


\section{CONTENTS (continued)}

5.2 LIQUID EFFLUENT STREAMS . . . . . . . . . . . 5-12

5.2.1 Used Cooling Water Stream . . . . . . . . . . . . . 5-12

5.2.2 Steam Condensáte Stream . . . . . . . . . . . 5-16

6.0 EFFLUENT MONITORING/SAMPLING SYSTEM DESIGN CRITERIA . . . . . . . 6-1

6.1 NEW FACILITIES .................. . . 6-1

6.2 EXISTING FACILITIES . . . . . . . . . . . . . . . . . 6-1

6.2 .1 Gaseous Effluent Streams . . . . . . . . . . . 6-1

6.2 .2 Liquid Effluent Streams ........... . . 6-3

7.0 CHARACTERIZATION OF CURRENT EFFLUENT MONITORING SYSTEMS . . . . . 7-1

7.1 INSTRUMENTATION DESCRIPTION . . . . . . . . . . . . . 7-1

7.1.1 Gaseous Effluent Streams . . . . . . . . . . . 7-1

7.1 .2 Liquid Effluent Streams . . . . . . . . . . 7-20

8.0 HISTORICAL MONITORING/SAMPLING DATA FOR EFFLUENT STREAMS . . . . . 8-1

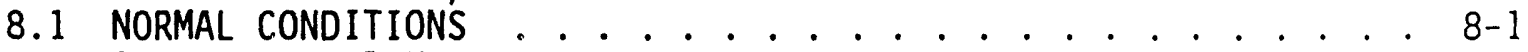

8.1.1 Vessel Vent . . . . . . . . . . . . . . 8-1

8.1.2 Building Ventilation ............ 8-1

8.1.3 Steam Condensate . . . . . . . . . . . . . . 8-3

8.1 .4 Cooling Water.............. 8-5

8.2 UPSET CONDITIONS . . . . . . . . . . . . . . . . . . .

9.0 SAMPLING ANALYSIS . . . . . . . . . . . . . . 9-1

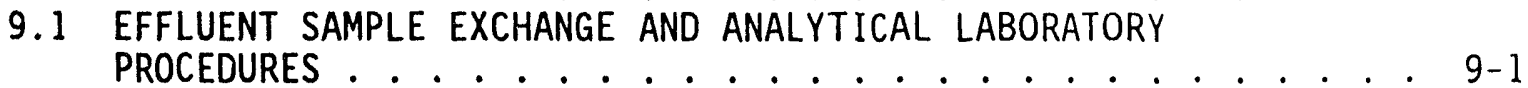

9.1.1 Vessel Vent and Building Ventilation Sample

Exchange Process .......... . . 9-1

9.1.2 Steam Condensate Sampling Process . . . . . . . . . . 9-9

9.1.3 Cooling Water Sampling Process . . . . . . . . . . 9-10

9.1.4 Sample Analysis for 242-A Liquid Effluents . . . . . . 9-11

9.2 SAMPLING AND DATA CHAIN OF CUSTODY ........... . . . .11

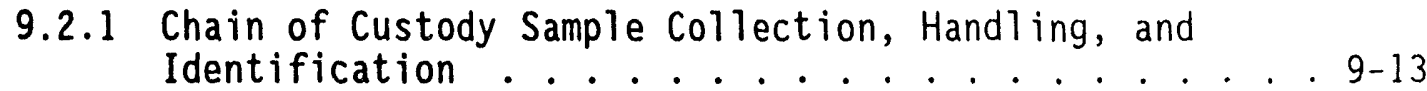

9.2.2 Transfer of Custody and Shipment ...... . . 9-14

9.2.3 U.S. Department of Energy Analytical and Laboratory

Guidelines ............... 9-14

10.0 NOTIFICATIONS AND REPORTING . . . . . . . . . . . . 10-1

10.1 REQUIREMENTS ............. . . . . . . . . . . . .

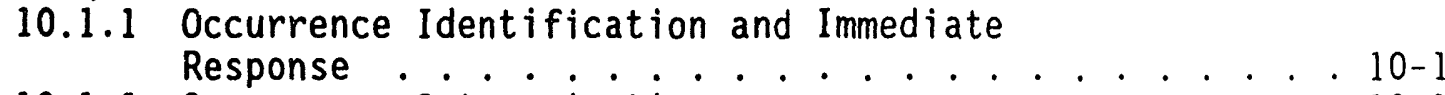

10.1.2 Occurrence categorization .......... . . . . . .

10.2 OCCURRENCE CATEGORIZATION . . . . . . . . . . . . 10-2

10.2.1 Radioactive Releases . . . . . . . . . . . . . . 10-2

10.2.2 Hazardous Substances Releases . . . . . . . . . 10-3

10.2.3 Discovery of Radioactive or Hazardous Material

Contamination Due to U.S. Department of Energy

Operations .......... 10-3

10.2.4 Agreement/Compliance Activities . . . . . . . 10-4 


\section{CONTENTS (continued)}

11.0 INTERFACE WITH THE OPERATIONAL ENVIRONMENTAL SURVEILLANCE

PROGRAM . . . . . . . . . . . . . . . 11-1

11.1 DESCRIPTION . . . . . . . . . . . . . . . . . . . 11-1

11.2 PURPOSE . . . . . . . . . . . . . . . . 11-1

11.3 BASIS . . . . . . . . . . . . . . . . . . . . .

11.4 MEDIA SAMPLED AND ANALYSES PERFORMED ...........11-1

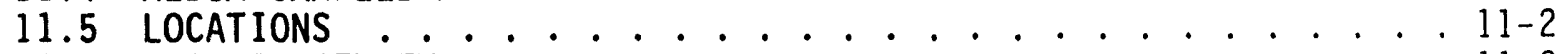

11.6 PROGRAM REVIEW . . . . . . . . . . . . . . . . . . . . . 11-2

11.7 SAMPLER DESIGN . . . . . . . . . . . . . . . . . 11-2

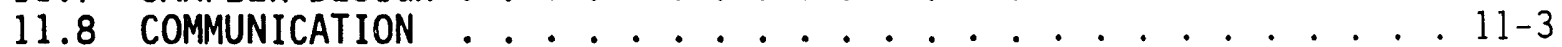

11.9 REPORTS ........................ . . . . . . . .

12.0 QUALITY ASSURANCE ...................... 12-1

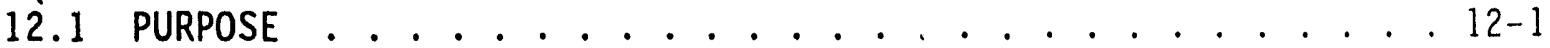

12.2 OBJECTIVE . . . . . . . . . . . . . . . 12-1

12.3 REQUIREMENTS . . . . . . . . . . . . 12-1

12.4 FACILITY-SPECIFIC REQUIREMENTS . . . . . . . . . . . . . . . . 12-1

13.0 INTERNAL AND EXTERNAL PLAN REVIEW ............... . . . . .

14.0 EFFLUENT MONITORING/SAMPLING ASSESSMENT . . . . . . . . . . . 14-1

14.1 COMPL IANCE ASSESSMENT ............... . . . . . . . . . .

14.1.1 Regulations Governing Airborne Emissions . . . . . . . 14-1

14.1.2 Gaseous Streams Point-By-Point Compliance Assessment .... 14-3

14.1.3 Summary of Gaseous Effluent Sampling/Monitoring Deficiencies ........... . . 14-56

14.1.4 Regulations Governing Liquid Effluent Streams . . . 14-57

14.1.5 Liquid Streams Sampling/Monitoring Compliance
Assessment . . . . . 14-57

14.1.6 Miscellaneous Assessment/Comments . . . . . . . . 14-58

14.2 EXEMPTIONS . . . . . . . . . . . . 14-58

14.3 SYSTEM UPGRADES REQUIRED FOR COMPLIANCE . . . . . . . . 14-59

15.0 SUMMARY AND CONCLUSIONS ................... . . . . . .

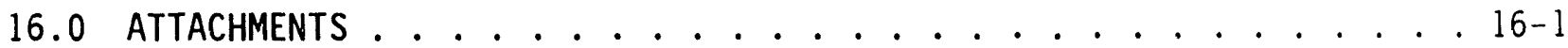

16.1 REFERENCES ................... 16-1 
WHC-EP-0466-1

\section{LIST OF FIGURES}

2-1 The Hanford Site Map ...... . . . . . . . . . 2-2

2-2 The 242-A Evaporator Site Plan ............. 2-3

2-3 The 242-A Evaporator Firs: Tloor Plan . . . . . . . . . 2-4

2-4 The 242-A Evaporator Second Floor Plan .......... . 2-5

2-5 Elevations of Buildings 242-A and 242-AB ......... . . 2-6

2-6 The 242-A Evaporator Simplified Process Schematic. . . . . . . 2-9

2-7 The 242-A Evaporator Simplified Process Flow Diagram . . . . . 2-10

2-8 Evaporator Feed Types . . . . . . . . . . . . 2-13

4-1 The 242-A Evaporator Block Diagram . . . . . . . . . . . 4-2

4-2 The 242-A Evaporator Vessel Vent System . . . . . . . . . . 4-3

4-3 Process Configuration for the 242-A Cooling Water Stream . . . . . 4-8

4-4 242-A Evaporator Steam Condensate Waste Stream . . . . . . . . . 4-11

4-5 242-A Evaporator Drain System . . . . . . . . . . . . . 4-14

5-1 The 242-A Evaporator Used Raw Water System . . . . . . . . . . . 5-14

5-2 The 242-A Evaporator Steam Condensate System . . . . . . . . 5-18

7-1 Generic Airborne Effluent Sampling and Monitoring System . . . . 7-2

7-2 P\&ID Used Raw Water System . . . . . . . . . . . . . . . 7-34

7-3 P\&ID Steam Condensate System . . . . . . . . . . . 7-38 
WHC-EP-0466-1

\section{LIST OF TABLES}

2-1 Maximum Evaporator Separator Vessel Radionuclide Source Term. . . . . . . . . . . . . . . . 2-15

2-2 Evaporator Separator Nonradionuclide Inventory at Risk . . . . 2-17

2-3 Evaporator Separator Nonradionuclide Source Term . . . . . . 2-18

2-4 Evaporator Separator Nonradionuclide Data . . . . . . . . . 2-22

2-5 Evaporator Separator Nonradionuclide Data . . . . . . . . . 2-23

2-6 Process Condensate Nonradionuclide Inventory at Risk . . . . . 2-28

2-7 Process Condensate Nonradionuclide Source Term . . . . . . . . 2-29

2-8 Process Condensate Nonradionuclide Source Term Data . . . . . . . 2-35

2-9 Process Condensate Radionuclide Data . . . . . . . . . . . 2-39

2-10 Process Condensate Radionuclide Data . . . . . . . . . . . . 2-40

2-11 Process Condensate Radionuclide Data . . . . . . . . . . . 2-42

2-12 Process Condensate Radionuclide Data . . . . . . . . . . 2-43

2-13 Process Condensate Radionuclide Source Term . . . . . . . . . . 2-44

3-1 Applicable Regulations and Standards . . . . . . . . . . . 3-2

4-1 Portable Radiation Detection and Measurement Instruments . . . . 4-6

4-2 Stack 296-A-22 Gaseous Radioactive Effluent Emissions . . . . . 4-18

4-3 Stack 296-A-22 Offsite Dose Cross-Check............ . 4-18

4-4 Stack 296-A-22 Gaseous Nonradioactive Emissions. . . . . . . . . 4-22

4-5 Stack 296-A-21 Gaseous Radioactive Effluent Emissions..... . . 4-23

4-6 Stack 296-A-21 Offsite Dose Cross-Check . . . . . . . . . . . 4-23

4-7 Steam Condensate Radionuclide Source Term . . . . . . . . . . . 4-24

4-8 Steam Condensate Nonradionuclide Source Terms . . . . . . . . . 4-25

4-9 Cooling Water Radionuclide Source Term . . . . . . . . . . 4-27

4-10 Cooling Water Nonradionuclide Source Term . . . . . . . . . . 4-28

4-11 Raw Water Nonradionuclide Source Term . . . . . . . . . . . 4-30 
WHC-EP-0466-1

\section{LIST OF TABLES (continued)}

4-12 Raw Water/Cooling Water CERCLA RQ Comparison .......... . 4-31

5-1 242-A Evaporator/Crystallizer Gaseous Effluent Streams . . . . . . 5-1

5-2 242-A Evaporator Vessel Ventilation Hazardous Analytes . . . . . . 5-8

5-3 296-A-21 Stack Flow ..................... 5-9

7-1 Monitoring Instrumentation for 242-A Vessel Ventilation System Exhaust Stack 296-A-22 . . . . . . . . . . . . . 7-16

7-2 Monitoring Instrumentation for 242-A Building Ventilation System Exhaust Stack 296-A-21 .............. . 7-21

7-3 Monitoring Instrumentation for 242-A Evaporator Used Raw Water System Waste Stream . . . . . . . . . . . . . 7-27

7-4 Monitoring Instrumentation for 242-A Steam Condensate System Waste Stream . . . . . . . . . . . . . . 7-30

8-1 Stack 296-A-22 Gaseous Radioactive Effluent Emissions Data . . . 8-2

8-2 Stack 296-A-21 Gaseous Radioactive Effluent Emissions Data . . . 8-3

8-3 Steam Condensate Radionuclide Effluent Release Data. . . . . . . 8-4

8-4 Cooling Water Radioactive Effluent Release Data . . . . . . . . . 8-6

9-1 Sample Electronic Data Processing Codes . . . . . . . . . . . 9-7

9-2 Radionuclide Detection Limit . . . . . . . . . . . . . 9-9

9-3 Sample Analyte List for 242-A Liquid Effluents . . . . . . . . . . 9-12

9-4 Laboratory Procedures . . . . . . . . . . . . . . . . 9-16

9-5 Data Analyses and Statistical Treatment . . . . . . . . . . 9-17

14-1 Vessel Vent Sampler Probe Design ............... 14-31

14-2 Building Ventilation Sampler Probe Design ........... . 14-31 


\section{LIST OF TERMS}

ALARA

AMU

ANSI

ASF

ASP

ASTM

BAT

CAM

CASS

CBRS

CERCLA

CFR

CRW

DAC

$D C G$

DDSSF

DOE

$D P$

DSI

DSSF

DST

DW

$E / C$

EDE

EDP

EHW

EMP

EMS

EP

EPA

ETF

FEMP

HEHF

HEPA

HP

HPT

HVAC

LCCS

LERF

M\&TE

MCS

MEI

MOV

NBS

NCRW

NESHAPS

NO/NC

NPDES as low as reasonably achievable aqueous makeup

American National Standards Institute ammonia scrubber feed

alarm set point

American Society for Testing and Materials best available technology

continuous air monitor

Computer Automated Surveillance System

Component-Based Recall System

Comprehensive Environmental Response

Compensation, and Liability Act of 1989

Code of Federal Regulations

cladding removal waste

derived air concentrations

derived concentration guide

dilute double-shell slurry feed

U.S. Department of Energy

differential pressure

Don't Say It - - Write It

double-shell slurry feed

double-shell tank

dangerous waste

Evaporator/Crystallizer

effective dose equivalent

electronic data processing

extremely hazardous waste

Environmental Monitoring Plan

effluent monitoring system

Environmental Protection group

U.S. Environmental Protection Agency

effluent treatment facility

Facility Effluent Monitoring Plan

Hanford Environmental Health Foundation

high-efficiency particulate air (filter)

Health Physics

Health Physics Technician

heating, ventilating, and air conditioning

laboratory customer computer system

Liquid Effluent Retention Facility

measuring and test equipment

monitor and control system

maximally exposed individual

motor-operated valve

National Bureau of Standards

neutralized cladding removal waste

National Emissions Standards for Hazardous

Air Pollutants

normally opened/normally closed

National Pollutant Discharge Elimination

System 


\section{LIST OF TERMS (continued)}
NWPA
OHP
OSR
$P C$
PF
PFP
PISCES
PNL
POP
POTW
PUREX
QA
QAPP
QAP jP
RCRA
REDOX
$\mathrm{RL}$
RQ
SC
SWP
TLD
TRU
TSD
UBC
URW
WAC
WHC

Nuclear Waste Policy Act of 1982

operational health physics

operational safety requirements

process condensate

protectioli factor

Plutonium Finishing Plant

Plant Instrumentation Surveillance

Calibration and Evaluation System

Pacific Northwest Laboratory

plant operating procedure

Publicly Owned Treatment works

Plutonium/Uranium Extraction (Plant)

Quality Assurance

Quality Assurance Program Plan

Quality Assurance Project Plan

Resource Conservation and Recovery Act

of 1976

Reduction 0xidation (Plant)

U.S. Department of Energy Field Office, Richland

reportable quantities

steam condensate

Special Work Permit

thermoluminescent dosimeter

transuranic (waste)

treatment, storage, and disposal

Uniform Building Code

used raw water

Washington Administrative Code

Westinghouse Hanford Company 
WHC-EP-0466-1

METRIC CONVERSION CHART

\begin{tabular}{|c|c|c|}
\hline \multicolumn{3}{|c|}{ INTO METRIC } \\
\hline If you know & Multiply by & To get \\
\hline \multicolumn{3}{|c|}{ Length } \\
\hline inches & 2.54 & centimeters \\
\hline feet & 30.48 & centimeîers \\
\hline \multicolumn{3}{|c|}{ Volume } \\
\hline gallons & 3.786 & liters \\
\hline cubic feet & 0.02832 & cubic meters \\
\hline \multicolumn{3}{|c|}{ Temperature } \\
\hline Fahrenheit & $\begin{array}{l}\text { Subtract } 32 \text { then } \\
\text { multiply by } 5 / 9 \text { ths }\end{array}$ & Celsius \\
\hline \multicolumn{3}{|c|}{ Pressure } \\
\hline inches water & 1.87 & $\mathrm{~mm} \mathrm{Hg}$ \\
\hline inches water & 249 & Pascal (Pa) \\
\hline \multicolumn{3}{|c|}{ OUT OF METRIC } \\
\hline \multicolumn{3}{|c|}{ Length } \\
\hline centimeters & 0.3937 & inches \\
\hline meters & 3.28 & feet \\
\hline \multicolumn{3}{|c|}{ Volume } \\
\hline milliliters & $1.247 \times 10^{-3}$ & cubic feet \\
\hline liters & 0.264 & gallons \\
\hline cubic meters & 35.31 & cubic feet \\
\hline \multicolumn{3}{|c|}{ Temperature } \\
\hline Celsius & $\begin{array}{l}\text { Multiply by } 9 / 5 \text { ths, then } \\
\text { add } 32\end{array}$ & Fahrenheit \\
\hline \multicolumn{3}{|c|}{ Pressure } \\
\hline $\mathrm{mm} \mathrm{Hg}$ & 0.5353 & inches water \\
\hline Pascal (Pa) & $4.02 \times 10^{-3}$ & inches water \\
\hline
\end{tabular}


WHC-EP-0466-1

This page intentionally left blank. 
WHC-EP-0466-1

\subsection{FACILITY EFFLUENT MONITORING PLAN}

\subsection{INTRODUCTION}

The purpose of this section is to provide information on the policy, purpose, and scope of a facility effluent monitoring plan (FEMP).

\subsubsection{Policy}

It is the policy of the U. S. D.partment of Energy (DOE) and its contractor, Westinghouse Hanford Company (Westinghouse Hanford), to conduct facility effluent monitoring (sampling and monitoring) that is adequate in determining whether the public and the environment are s'ificiently protected during DOE operations; and to determine whether operatiu:s are in compliance with DOE and other applicable federal, state, and local emission standards and requirements. It is also DOE and Westinghouse Hanford policy that efflueni monitoring programs meet high standards of quality and credibility and that their operations are in compliance with federal, state, and local emission standards and requirements.

\subsubsection{Purpose}

The purpose of this plan is to fulfill the DOE requirement (DOE 5400.1) (DOE 1990a) for a FEMP to exist for each site, facility, or process that uses, generates, releases, or manages significant pollutants of radioactive or hazardous materials that could affect public and employee safety and the environment. This document is specifically intended to meet this requirement for the 242-A Evaporator/Crystallizer (E/C) facility on the Hanford Site.

The purpose of the FEMP is to assess and document this information to determine if the monitoring, sampling, and controls are sufficient to protect the public and the environment and to assess whether these systems are in compliance with all federal, state, and local requirements and regulations.

\subsubsection{Scope}

The scope of this document includes program plans for monitoring and characterizing radioactive and nonradioactive hazardous materials discharged in 242-A E/C facility effluents. This plan includes complete documentation for both gaseous and liquid effluent monitoring systems (EMS) for both radioactive and nonradioactive hazardous pollutants that could be discharged under routine and/or upset conditions.

The FEMPs are written to provide sufficient information on the effluent characteristics and the EMS of facilities so that a compliance assessment against the applicable requirements may be easily accomplished. Adequate details are supplied so that radioactive and hazardous material source terms related to specific effluent streams and, in turn, to specific discharge points can be finally compared to the EMS capability. 


\subsubsection{Discussion}

The FEMPs are required for facilities if the total projected effective dose equivalent* (EDE) to any member of the public from radionuclide airborne emissions at the facility exceeds $0.1 \mathrm{mrem} / \mathrm{yr}$ from any one discharge point or if any one regulated material dischargrd over a 24-h period from a facility exceeds $100 \%$ of the Comprehensive Environmental Response, Compensation, and Liability Act of 1980 (CERCLA) Reportable Quantity (RQ) as listed in Tit1e 40 Code of Federal Regulations (CFR) Part 302.4, "Designation of Hazardous Substances" (EPA 1991c). A FEMP is required for a facility if the liquid effluent stream contains measurable radionuclide concentrations and the concentrations exceed the drinking water standards. The FEMPs are selfsupporting in-depth documents that detail the effluents, the effluent discharge points, the monitoring systems, the sampling protocol, and the controls at the facility.

This document was prepared under the guidance given in WHC-EP-0438-1, A Guide For Preparing Hanford Facility Effluent Monitoring Plans (WHC 1991a).

*An EDE is defined to be the summation of the products of the dose equivalent received by specific tissues of the body and a tissue-specific weighing factor. The sum is a risk-equivalent value that can be used to estimate the health-effects risk of exposed individuals. The tissue-specific weighing factor represents the fraction of the total health risk resulting from uniform whole-body radiation that would be contributed by that particular tissue. The EDE includes the committed EDE from internal deposition of radionuclides, and the EDE caused by penetrating radiation from sources external to the body. The EDE is expressed in units of rem (or sievert). 
WHC-EP-0466-1

\subsection{FACILITY DESCRIPTION}

This chapter is provided to briefly describe, and thus introduce, the 242-A Evaporator facility.

\subsection{FACILITY PHYSICAL DESCRIPTION}

The 242-A Evaporator complex is located in the 200 East Area of the Hanford Site, which is located in the south-central region of Washington State. The 242-A Building is located south of the 241-A and 241-AX Tank Farms and north of the 242-AW Tank Farm. The facility location and layout are shown in Figures 2-1 and 2-2. The 242-A Evaporator complex covers approximately $1,394 \mathrm{~m}^{2}\left(15,000 \mathrm{ft}^{2}\right)$.

The 242-A Building contains the evaporator vessel and supporting process equipment. The building ventilation exhaust fans and high-efficiency particulate air (HEPA) filter housings are located on the north side of the building. An emergency diesel generator is located on the southeast side of the building. Raw water, steam, and electrical power are provided to the 242-A Building from existing service facilities in the 200 East Area.

In genera1, the 242-A Evaporator facility can be divided into three areas: process, service, and operating. The process area includes the evaporator room, pump room, condenser room, and ion exchange enclosure. The service area includes the aqueous makeup unit (AMU) room, loadout and hot equipment storage room, loading room, and heating, ventilating, and air conditioning (HVAC) room. The operating areas include the control room, men's and women's change rooms, lunchroom, office, and storage rooms.

The principal process components of the $E / C$ system are located in the process building (242-A), which includes supporting service and operating areas. The 242-A Evaporator is a multistory, structural steel, reinforcedconcrete building and comprises two adjoining, but structurally independent buildings, herein designated $A$ and $B$. The control room building $(242-A B)$ is adjoined to, but structurally independent of, Building 242-A. An additional building, 242-A-81, is located directly south of Building 242-A, adjacent to the employee parking lot.

Building 242-A has plan dimensions of approximately $23.8 \mathrm{~m}$ $(75 \mathrm{ft})$ by $32.9 \mathrm{~m}(108 \mathrm{ft})$ and is $18.9 \mathrm{~m}(62 \mathrm{ft})$ above finished grade at its highest point. A portion of the building extends $3.05 \mathrm{~m}(10 \mathrm{ft})$ below grade. Floor plans and building elevations are shown in Figures 2-3, 2-4, and 2-5.

Structure A, which houses processing and service areas (e.g., evaporator room, HVAC room), is a reinforced concrete shear wall and slab structure with concrete mat footing in below-grade regions and spread footing elsewhere. It has plan dimensions of $15.2 \mathrm{~m}(50 \mathrm{ft})$ by $22.9 \mathrm{~m}(75 \mathrm{ft})$. The evaporator room section of structure $A$ is set $3.05 \mathrm{~m}(10 \mathrm{ft})$ below grade and is sized to contain the entire liquid volume of the evaporator vessel should it somehow be accidentally released to the room. For shielding and contamination containment, the walls are constructed of $0.56-\mathrm{m}-(1.83-\mathrm{ft}-)$ thick reinforced concrete. 
Figure 2-1. The Hanford Site Map.

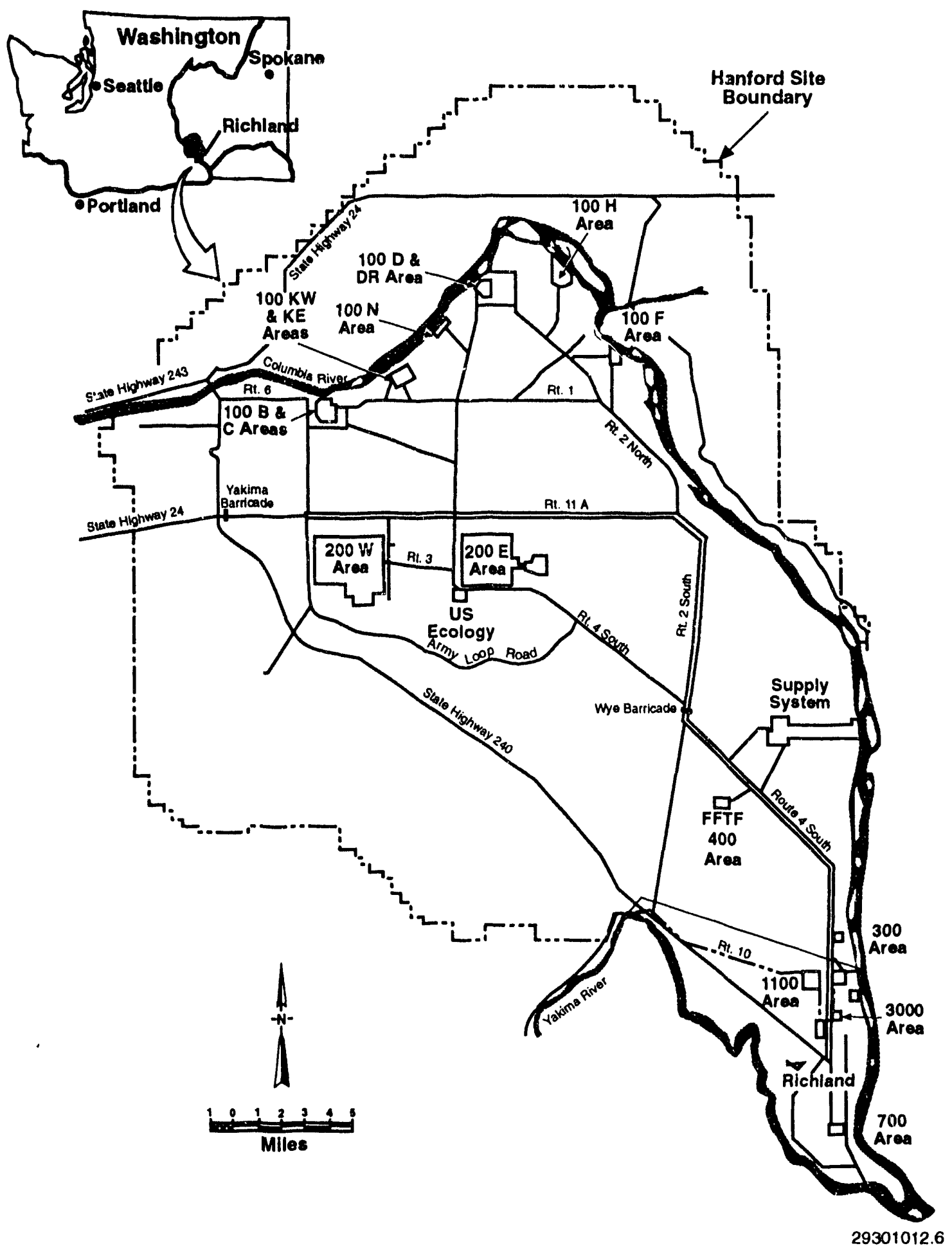


Figure 2-2. The 242-A Evaporator Site Plan.

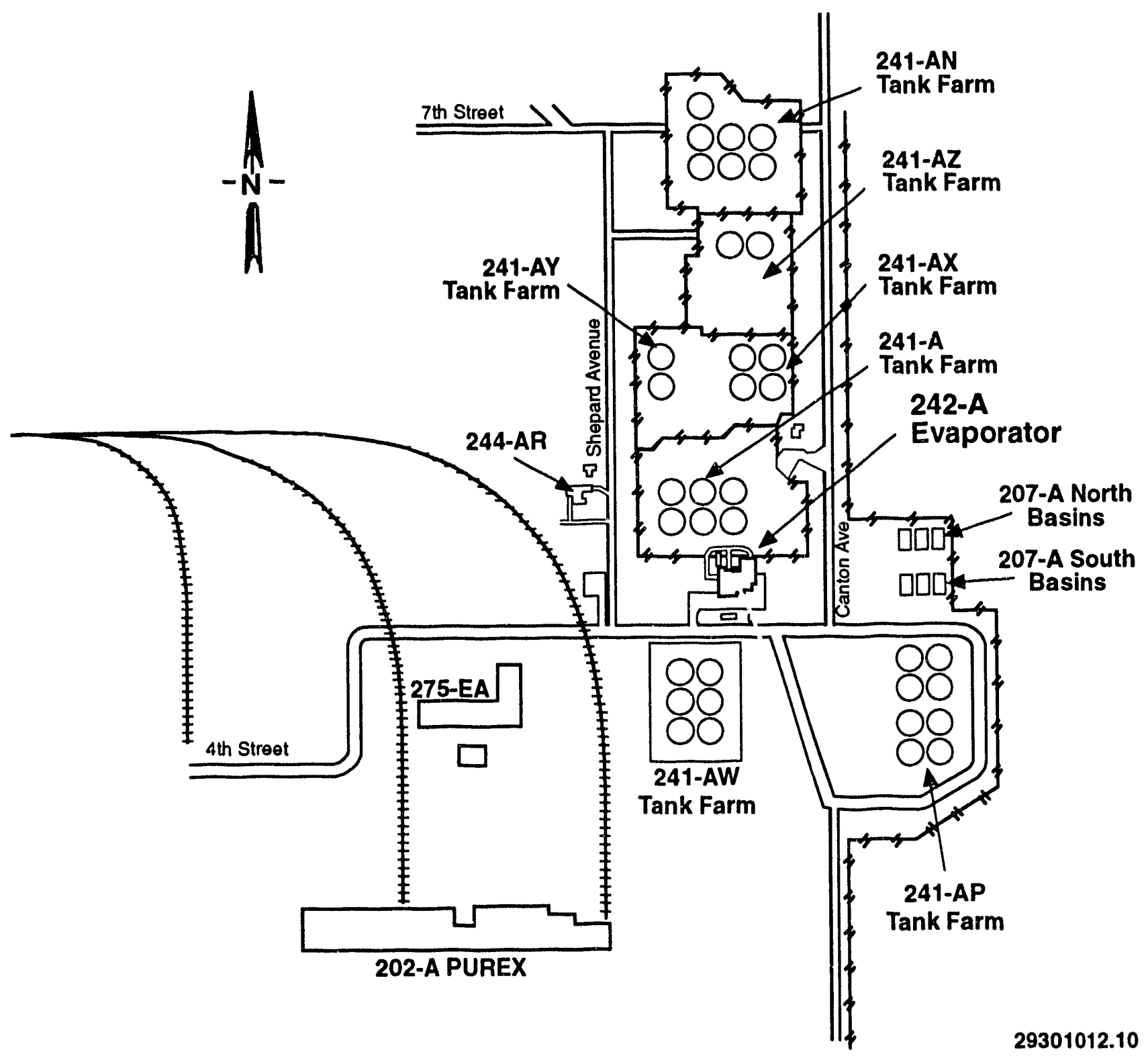


Figure 2-3. The 242-A Evaporator First Floor Plan.

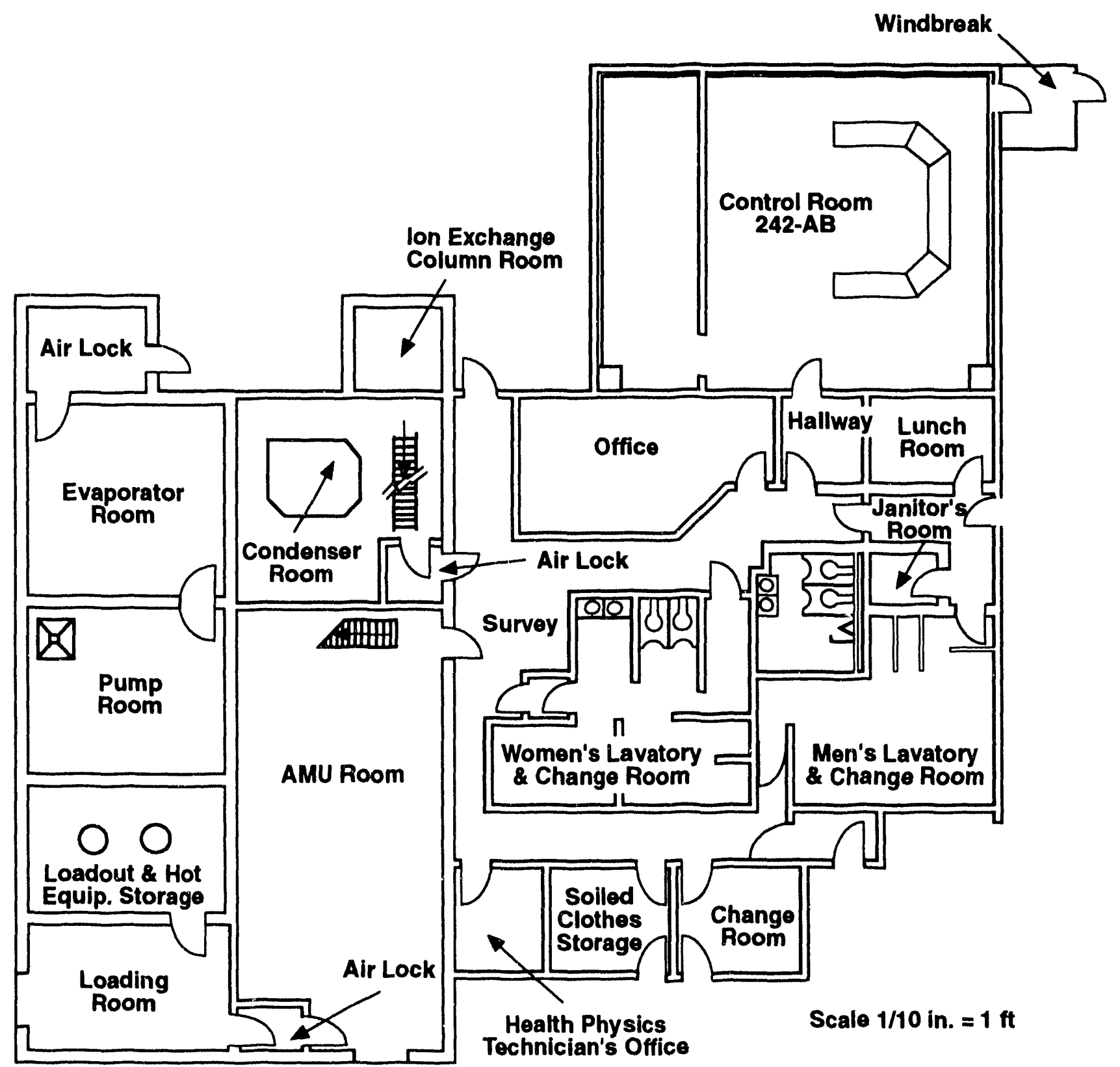

Note:

AMU = Aqueous Makeup

The new control room is identified as 242-AB Building.

Other rooms are part of the 242-A Building. 
Figure 2-4. The 242-A Evaporator Second Floor Plan.

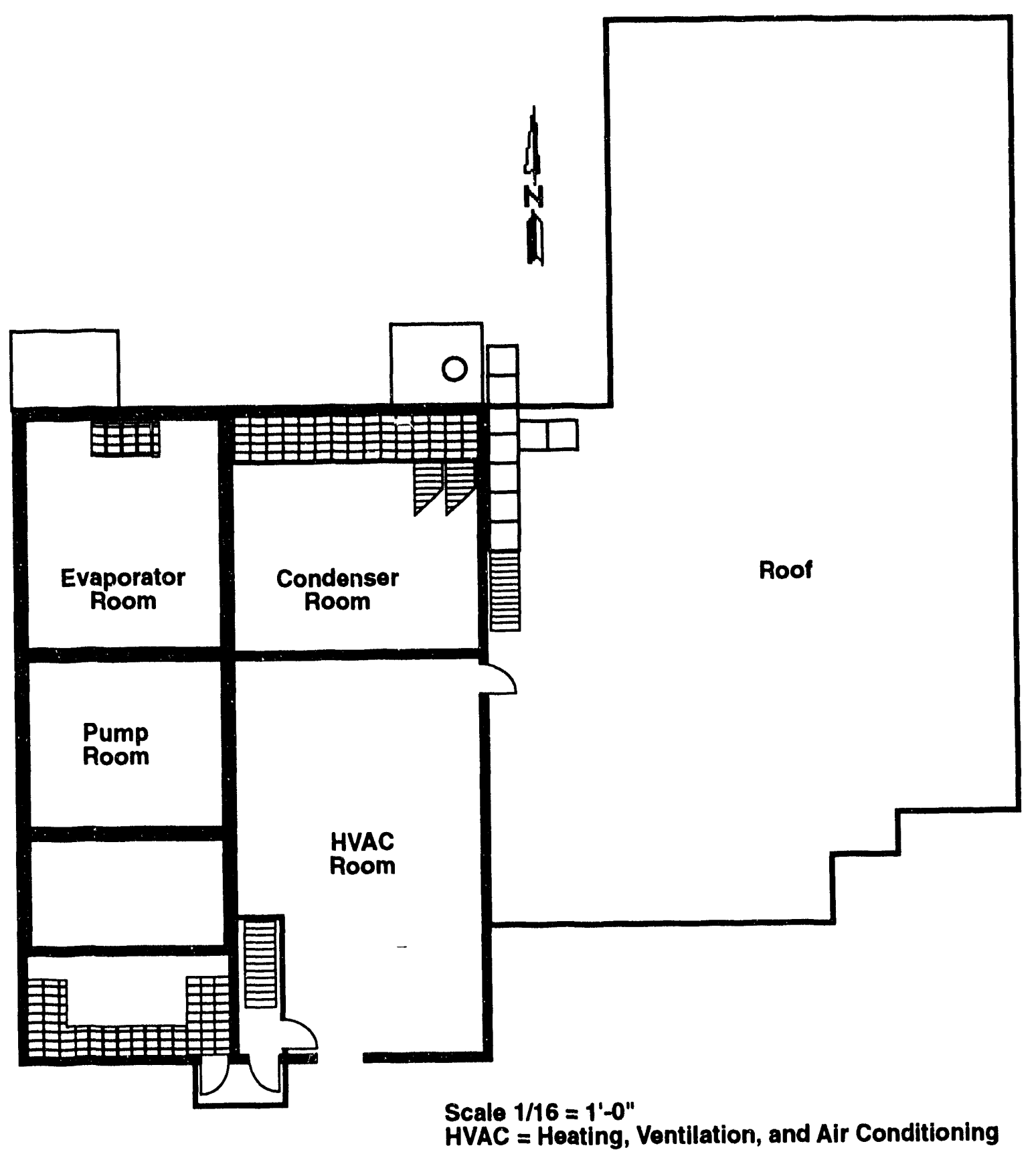

29301012.13 
Figure 2-5. Elevations of Buildings 242-A a $\cdot d$ 242-AB.

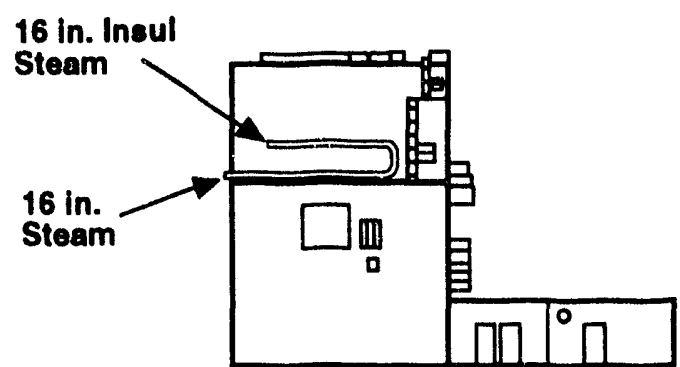

North Elevation

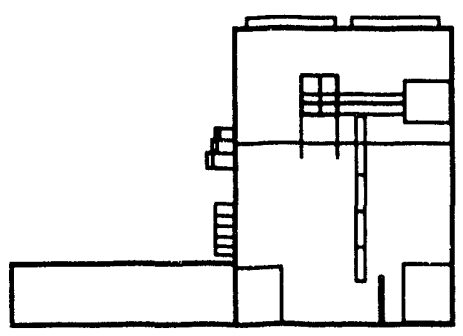

South Elevation

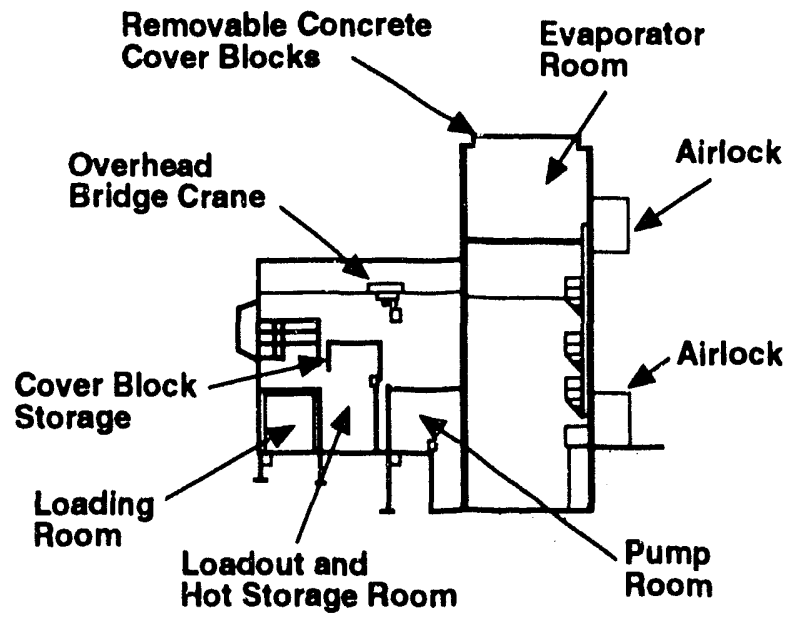

HVAC = Heating, Ventilation, and Air Conditioning
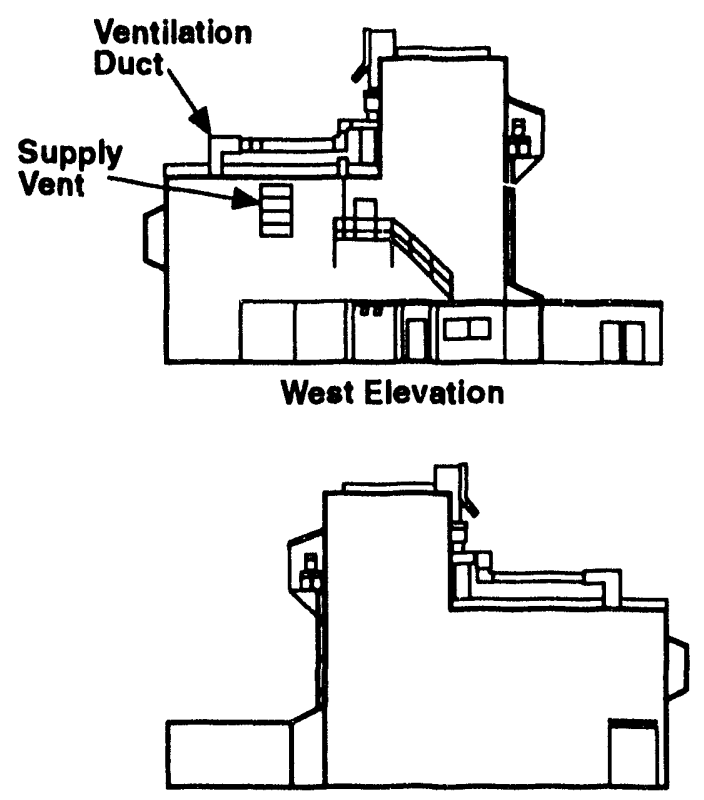

East Elevation
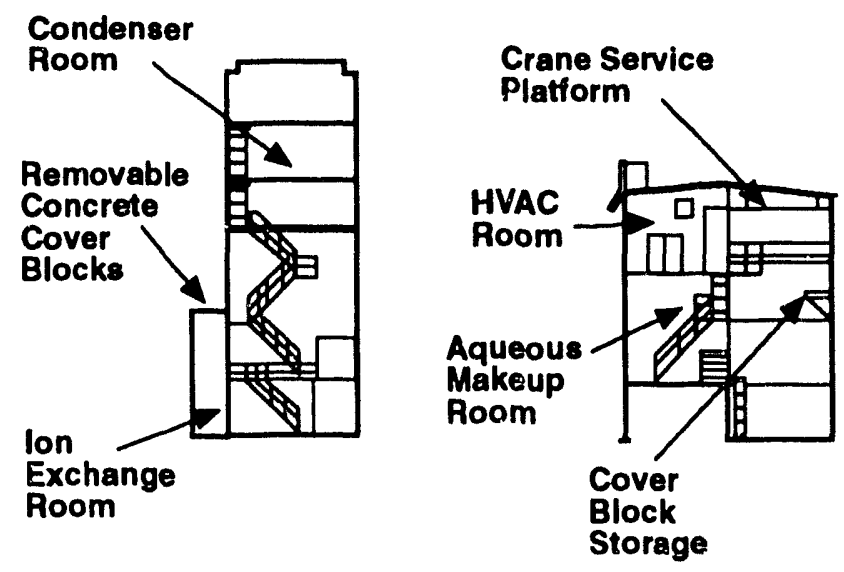

29301012.11 
Structure B of Building 242-A is separated from Structure A by a seismic joint. It houses operating and personnel support areas. The roof consists of metal decking supported by structural steel members spanning to reinforced concrete block walls. The foundations for structure $B$ are continuous strip footings. This structure measures $3.35 \mathrm{~m}(11 \mathrm{ft})$ high with approximate plan dimensions of $12.8 \mathrm{~m}(42 \mathrm{ft})$ by $14.3 \mathrm{~m}(47 \mathrm{ft})$. It was constructed in accordance with Uniform Building Code (UBC 1991) requirements.

Building 242-AB houses the control room for the evaporator. The roof consists of metal decking supported by structural steel members spanning to reinforced concrete block walls. This structure is $12.2 \mathrm{~m}(40 \mathrm{ft})$ by $13.1 \mathrm{~m}$ $(43 \mathrm{ft})$, with a height close to that of structure $B$. Building $242-A B$ was constructed in accordance with UBC requirements.

Building 242-A-81 is the water services building for the 242-A E/C facility. This building houses the valves and filters for supplying raw process water to the 242-A Evaporator. Building 242-A-81 is an insulated pre-engineered metal building placed on a concrete slab. The building is approximately $6.1 \mathrm{~m}(20 \mathrm{ft})$ by $8.5 \mathrm{~m}(28 \mathrm{ft})$ and has a nominal height of $3.05 \mathrm{~m}(10 \mathrm{ft})$. Building $242-A-81$ was constructed in accordance with UBC requirements.

There are six 265,000-L- (70,000-ga1-) capacity cement retention basins located east of the evaporator building. These are designated as the 207-A Retention Basins. Each basin is approximately $12.2 \mathrm{~m}$ (40 ft) wide by $27.4 \mathrm{~m}(90 \mathrm{ft})$ long and $1.5 \mathrm{~m}(5 \mathrm{ft})$ deep. The north three basins are used for holding steam condensate from the 242-A Evaporator before discharge to the $B$ Pond system. Each of these three basins, as part of the recent 242-A facility upgrade, has been fitted with a high-density polyethylene protective liner and cover that will serve as an additional containment barrier. The design of these barriers was based on the composition of the steam condensate waste stream and the rate at which the basin could be emptied. The purpose of the steam condensate retention basins is to retain the condensate while sample analyses are being performed. The condensate is sampled in the condenser room before discharge to the basins. A laboratory analysis of the sample is performed to verify compliance with environmental regulations. The other three basins were, in the past, used to hold process condensate from the 242-A Evaporator. These three basins will not be used in the future and are scheduled for closure.

The 207-A Building is an enclosed pump pit containing the pumps, piping, and diversion control valving required for handling the steam condensate stream. The steam condensate (SC) gravity flows from 242-A to the 207-A Building. The SC can be routed to any one of the three SC retention basins by opening the appropriate motor-operated valve (MOV). The pumps can move SC in the basins to either tne B Pond system or back to the 242-A Evaporator feed tank (241-AW-102) via the A-350 catch tank. The building is constructed of reinforced concrete.

For a more detailed facility description, reference may be made to SD-WM-SAR-023, 242-A Evaporator/Crystallizer Safety Analysis Report (WHC 1988a). 
WHC-EP-0466-1

\subsection{PROCESS DESCRIPTION}

The 242-A Evaporator is the primary waste concentrator for Hanford Site waste that is stored in underground double-shell tanks (DST). Low-heatgenerating 1 iquid waste $(<0.1 \mathrm{Btu} / \mathrm{h} / \mathrm{gal})$ that contains relatively small amounts of fission products is stored in the DSTs. The 242-A Evaporator uses evaporative concentration followed by crystallization and precipitation of salts to reduce the volume of waste, thus reducing the amount of tank space required for storage. The facility receives a mixed waste stream containing radionuclides in excess of release limits as well as organic and inorganic constituents. It separates the waste into two streams as follows:

- One waste stream (concentrated slurry stream) containing essentially all of the radionuclides and inorganic constituents (an extremely hazardous waste)

- One waste stream (process condensate) containing volatile organic materials and greatly reduced concentrations of radionuclides.

The 242-A Evaporator receives a mixed blend feed from DST 241-AW-102. The feed consists of unprocessed and processed waste as well as recycled liquid that is removed from storage tanks after solids have settled. The feed is pumped into the recirculation line on the upstream side of the reboiler at a rate controlled to maintain a constant liquid level in the vapor-liquid separator. As the feed enters the recirculation line, it blends with the main process slurry stream that flows to the reboiler. A simplified schematic of the 242-A Evaporator process is shown in Figure 2-6 and a simplified flow diagram is shown in Figure 2-7.

In the reboiler, the mixture is heated slightly to a specific operating temperature, normally 38 to $77^{\circ} \mathrm{C}\left(160\right.$ to $\left.170^{\circ} \mathrm{F}\right)$, by using $0.20-0.68 \mathrm{~atm}$. gauge [ 3 to $10 \mathrm{lbf} / \mathrm{in}^{2}$ (gauge)] steam. The low-pressure steam provides adequate heat input, and the resulting low temperature differential across the reboiler helps minimize scale formation on the heat transfer surfaces.

The heated slurry stream is discharged from the reboiler to the vaporliquid separator, which is maintained at a pressure of 35 to 85 torr $[0.68$ to $1.64 \mathrm{lbf} / \mathrm{in}^{2}$ (absolute)]. Under this reduced pressure, a fraction of the water in the heated slurry flashes to steam and is drawn through two wire-mesh deentrainer pads into a $1.06-\mathrm{m}-(42-\mathrm{in.}-)$ diameter vapor line that leads to the primary condenser. As evaporation takes place in the separator vessel, the slurry becomes supersaturated. This supersaturation promotes the growth of existing crystals and forms some new salt crystals in the slurry liquor. After the process slurry has remained in the vapor-liquid separator approximately $2 \mathrm{~min}$, the slurry flows to the recirculation pump (P-B-1) suction via the bottom of the separator vessel and the lower recirculation line. The recirculation pump discharges the slurry back to the reboiler through the upper recirculation line, thus completing the process circuit. The process is continuous with typical stream flow rates of 341 to $530 \mathrm{~L} / \mathrm{min}$ (90 to $140 \mathrm{gal} / \mathrm{min}$ ) from the feed tank, 76 to $227 \mathrm{~L} / \mathrm{min}(20$ to $60 \mathrm{gal} / \mathrm{min}$ ) for the condensate, and 163 to $341 \mathrm{~L} / \mathrm{min}$ (43 to $90 \mathrm{gal} / \mathrm{min}$ ) for the slurry discharge. 
WHC-EP-0466-1

Figure 2-6. The 242-A Evaporator Simplified Process Schematic.

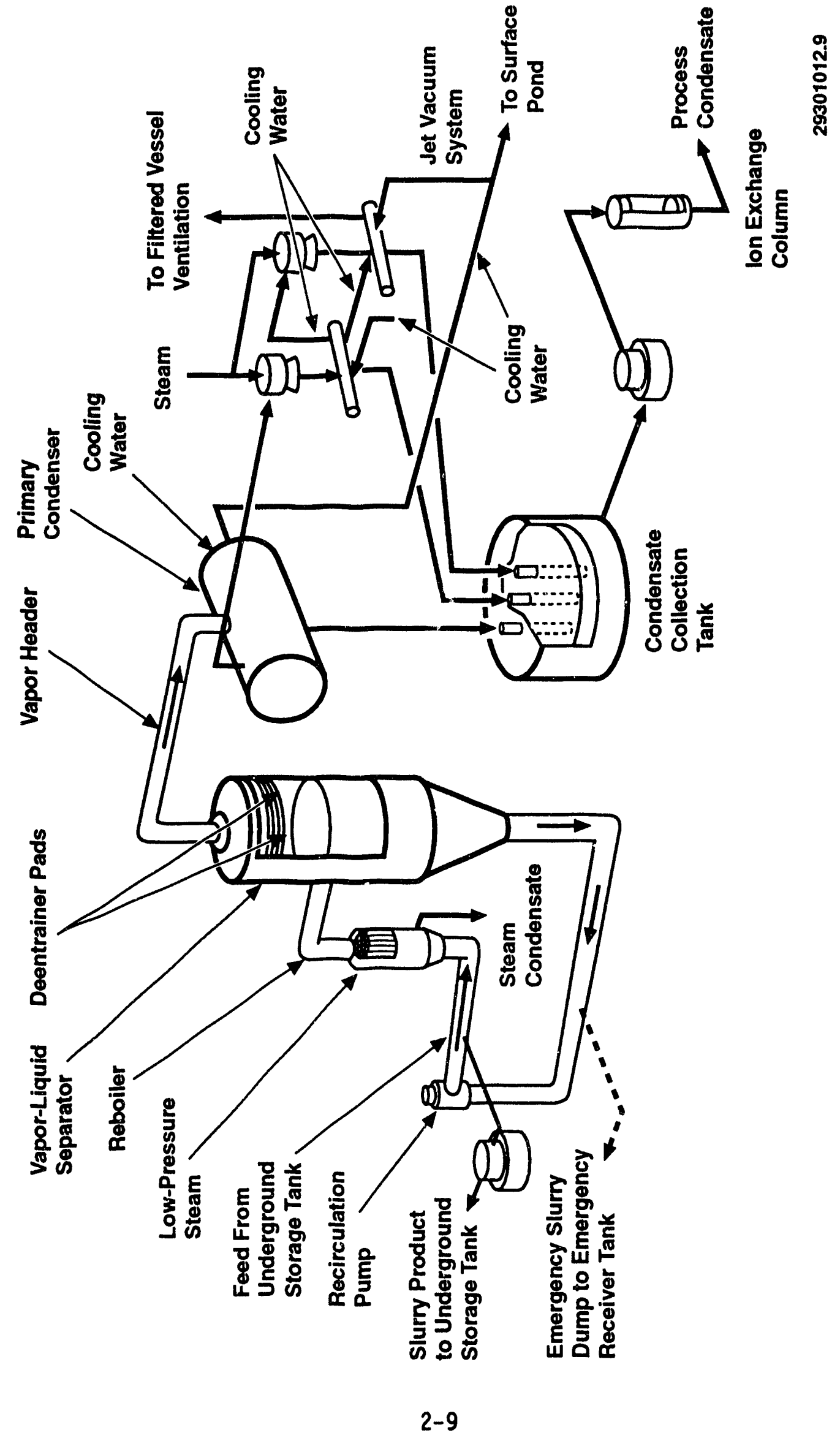


Figure 2-7. The 242-A Evaporator Simplified Process Flow Diagram.

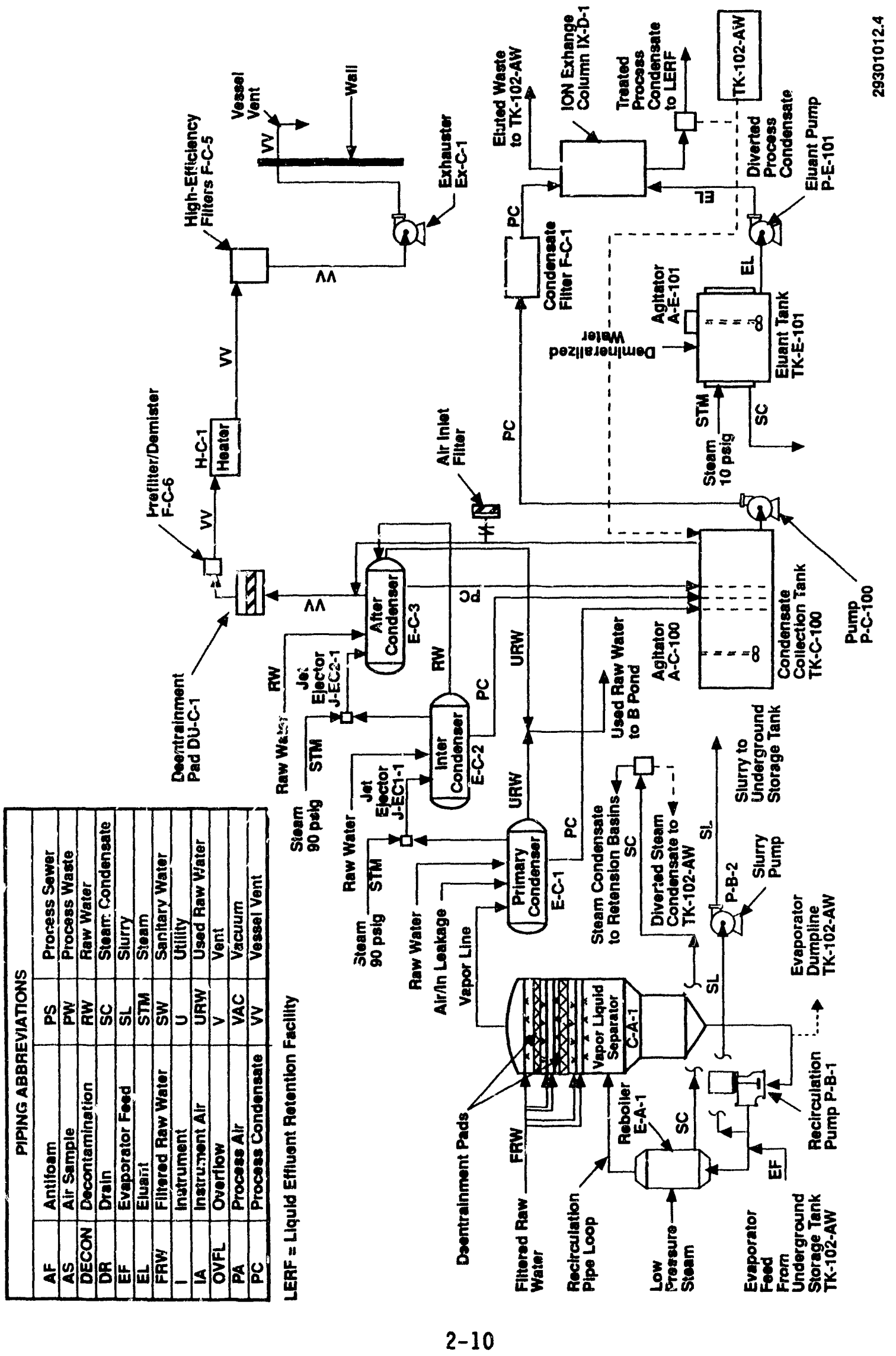


The recirculation pump moves waste at high velocities through the reboiler to accomplish the following:

- Improve the heat transfer coefficient

- Reduce fouling of heat transfer surfaces

- Keep solids in suspension

- Permit transfer of large quantities of heat with only a small change to the temperature of the solution being heated.

The static pressure of the solution above the reboiler is sufficient to suppress the boiling point so the solution will not boil in the reboiler tubes. Boiling occurs only near or at the liquid surface in the vapor-liquid separator.

When the process solution has been concentrated to the desired specifications, a small fraction is withdrawn from the upper recirculation 7 ine upstream of the feed addition point and is pumped by the slurry pump $(P-B-2)$ to underground storage tanks. In the storage tanks the slurry is allowed to separate into solid and liquid layers by settling. The liquid layer is removed and may be set aside, or returned to the feed tank and mixed with other evaporator waste feed stocks.

Because of the high concentration of solids in the slurry, the transfer lines from the evaporator to the tank farm settling tanks have the potential to plug because of settling solids. The slurry pump is designed for high pressures so the slurry can be transferred at high velocities to minimize the potential for this to occur.

Pressure in the vapor-1iquid separator is maintained at approximately 35 to 85 torr [0.68 to $1.64 \mathrm{lbf} / \mathrm{in}^{2}$ (absolute)] via the primary condenser and process vapor line by a two-stage steam-jet eductor system. Steam from the primary jet and the secondary jet, respectively, discharges to the intercondenser and after condenser. Both condensers drain to the process condensate collection tank (TK-C-100), while noncondensables are filtered and discharged to the atmosphere via the vessel vent system.

\subsection{IDENTIFICATION AND CHARACTERIZATION OF POTENTIAL SOURCE TERMS}

This section provides information that identifies and characterizes all potential process source terms present in the facility. The source terms are the types and quantities of mixed waste brought into the facility and the process chemicals that are stored in the facility.

\subsubsection{Background Information}

Waste to be treated at the facility is received from DSTs via the evaporator feed tank (DST 102-AW). The waste stored in the DSTs is classified as a mixed waste because it contains both radioactive and dangerous chemical 
components. The waste is a dangerous waste (DW) because of its corrosivity and toxicity characteristics and nonspecific source listed waste and is an extremely hazardous waste (EHW) caused by toxicity (state criteria only), carcinogenicity, and persistence under the state mixture rule.

The 242-A Evaporator facility receives this mixed waste stream and separates the waste into two streams as follows:

- One waste stream containing essentially all of the radionuclides and inorganic constituents (an extremely hazardous mixed waste)

- One waste stream containing water and greatly reduced concentrations of radionuclides and the volatile organic materials (a DW containing minimal quantities of radionuclides).

These two streams exit the 242-A Evaporator treatment process. One stream (the slurry) contains most of the radionuclides and inorganics. It is recycled back to the DST system for storage and/or further treatment. The other stream (the process condensate) contains the volatile organics and water. It is pumped to the Liquid Effluent Retention Facility (LERF) where it is stored to await further treatment by the Effluent Treatment Facility (ETF). Under normal operating circumstances, neither of these streams is discharged to the environment so the streams are not considered effluents.

\subsubsection{Evaporator Feed Types}

Waste is processed through the 242-A Evaporator in different batches according to its classification by total organic content, transuranic (TRU) content, and/or effects on the evaporation process. Dilute complex waste was received from the processing operations of $B$ Plant, while a mixture of noncomplexed waste is received from a number of operations, including the Plutonium-ilranium Extraction (PUREX) Plant, single-shell tank saltwell pumping, ard $N$ Reactor. A feed-type flowchart is shown in Figure 2-8.

Waste stored in the DST facilities and treated by the 242-A Evaporator includes the following:

1. Complexed Waste: The complexed waste that is processed was generated during B Plant processing. This waste contains high amounts of total organics such as the complexants ethylenediamine tetraacetic acid (EDTA) and hydroxy ethylenediaminetetraacetic acid (HEDTA). This waste must be processed separately in the 242-A facility because of its adverse effects on the evaporation process and the potential for high TRU contents.

2. Dilute Noncomplexed Waste: This waste is the composite of a number of wastes. This waste may be mixed during collection and storage before treatment. It includes the following:

- PUREX nonaging waste or low-level waste including neutralized decladding waste supernate and ammonia scrubber feed (ASF) 
Figure 2-8. Evaporator Feed Types.

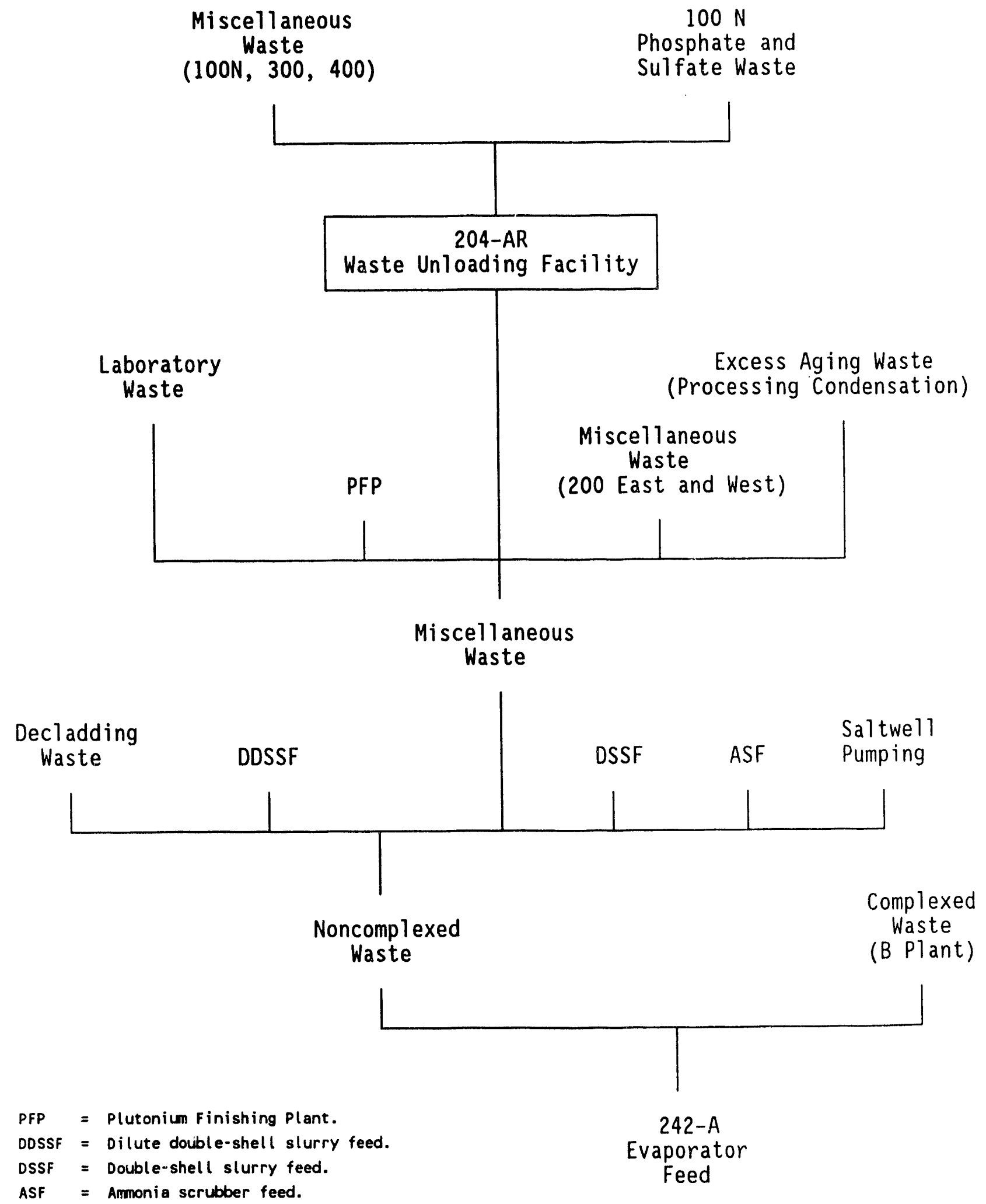


- Plutonium Finishing Plant (PFP) low-level processing supernate

- B Plant process and miscellaneous waste including cell drainage and vessel cleanout waste

- 222-S Laboratory and decontamination waste

- T Plant spent decontamination solutions

- 300 Area laboratory and fuels fabrication waste

- 400 Area equipment decontamination waste

- 100-N dilute phosphate decontamination waste and 100 Area spent fuel storage basin sulfate waste from ion exchange regeneration and sand filter backwashing (no longer generated)

- Single-shell tanks saltwell pumping waste

- Laboratory waste and decontamination solutions generated at Reduction/0xidation (REDOX) Complex

- Dilute double-shell slurry feed (DDSSF)

- Double-shell tank slurry feed (DSSF).

Feed concentrations and chemical composition will vary from run to run depending on the waste source, the degree to which the waste has previously been concentrated in the evaporator, and blending with other feeds. The largest portion of this waste is aqueous salts. The four primary feeds into the evaporator are consolidations of the waste sources listed above. These are the cladding removal waste (CRW) feed, the ASF, saltwell feed, and linked run feeds.

Radionuclide and nonradionuclide potential source terms within the facility are located within the evaporator/separator and reboiler process 10op.

\subsubsection{Evaporator Radiological Potential Source Terms}

Table 2-1 contains the bounding source term used for the evaporator. The bounding source term is the derived maximum possible term and is not necessarily the actual concentration present during everyday operation. These data were developed and presented in Internal Memo 76400-91-028, Rev 1 (WHC 1991C). This memo states that the radionuclide concentrations included in this source term are based on results from actual waste samples, historical evaporator campaigns, and projected operations. Those radionuclides which contributed very little to dose consequences were not included in the bounding source term developed in this memo.

The third column (the "Maximum separator inventory" column) is the quantity (represented in curies) of the particular radionuclide that could be 
Table 2-1. Maximum Evaporator Separator Vessel Radionuclide Source Term.

\begin{tabular}{|l|c|c|}
\hline \multicolumn{1}{|c|}{ Radionuclide } & $\begin{array}{c}\text { Maximum } \\
\text { concentration } \\
(\mu \mathrm{C} \mathrm{i} / \mathrm{mL})\end{array}$ & $\begin{array}{c}\text { Maximum separator } \\
\text { inventory } \\
(\mathrm{C} \mathrm{i})\end{array}$ \\
\hline${ }^{14} \mathrm{C}$ & 0.26 & 35.0 \\
\hline${ }^{60} \mathrm{Co}$ & 1.2 & 161.7 \\
\hline${ }^{79} \mathrm{Se}$ & 0.078 & 10.5 \\
\hline${ }^{90} \mathrm{Sr}$ & 220 & 29,644 \\
\hline${ }^{94} \mathrm{Nb}$ & 0.098 & 13.2 \\
\hline${ }^{99} \mathrm{Tc}$ & 2.0 & 269.5 \\
\hline${ }^{106} \mathrm{Ru}$ & 53 & $7,141.5$ \\
\hline${ }^{129} \mathrm{I}$ & 0.0026 & 0.35 \\
\hline${ }^{134} \mathrm{Cs}$ & 15 & 2,021 \\
\hline${ }^{137} \mathrm{Cs}$ & 1,500 & 202,119 \\
\hline${ }^{154} \mathrm{Eu}$ & 5.0 & 673.7 \\
\hline${ }^{155} \mathrm{Eu}$ & 7.0 & 943.2 \\
\hline${ }^{226} \mathrm{Ra}$ & 0.033 & 4.45 \\
\hline${ }^{238} \mathrm{Pu}$ & 0.0013 & 0.18 \\
\hline${ }^{239}, 240 \mathrm{Pu}$ & 0.16 & 21.6 \\
\hline${ }^{241} \mathrm{Pu}$ & 15 & 2,021 \\
\hline${ }^{241} \mathrm{Am}$ & 1.0 & 134.7 \\
\hline${ }^{244} \mathrm{Cm}$ & 0.013 & 1.75 \\
\hline
\end{tabular}

The following definitions are provided to help the reader understand the various units used in Table 2-1.

1. $\mathrm{Ci}$ is an abbreviation for curie, which is the unit used for measuring radioactivity and is defined as a unit of radioactivity; one curie is equal to 37 billion $\left(3.7 \times 10^{+10}\right)$ disintegrations per second $(37 \mathrm{billion} \mathrm{Bq})$. Note that because of the direct relationship between curies and the mass of a radionuclide, curies give the quantity of the material present as well as the activity (i.e., any activity expressed in curies not only gives the activity from a sample of a radionuclide, but also the amount of the nuclide present).

2. $\mu \mathrm{Ci}$ represents $1 / 1,000,000$ of a curie.

3. $\mathrm{ml}$ represents $1 / 1000$ of a liter. 
present at any time in the separator at its maximum capacity of $134,746 \mathrm{~L}$ $(35,600$ gal $)$. This column was derived by multiplying the maximum concentration value (found in the previous column) by the maximum evaporator vessel volumetric capacity.

\subsubsection{Evaporator Nonradiological Potential Source Terms}

Certain chemicals (referred to as nonradionuclides in this FEMP) are reportable under the CERCLA if any one regulated material (chemical) that is discharged or released over a $24-h$ period from a facility exceeds $100 \%$ of the $\mathrm{RQ}$ as listed in 40 CFR 302.4 (EPA 1991C). To ascertain if there is a potential for any such discharges or releases, it was first determined which chemicals are present in measurable quantities in the separator vessel. The tabulation of these chemicals is called an "inventory at risk" and is presented in Table 2-2. In other words, Table 2-2 is a 1 ist of those constituents that could become reportable under CERCLA if the entire contents of the separator vessel were released to the environment. This table was derived from, and is an extract from, the nonradionuclide source term presented in Table 2-3. Note that the second and third columns of Table 2-2 contain values that are equivalent but are expressed in different units. This method of tabulation is for the reader's convenience. Note al so that the values contained in Column 4 were calculated by multiplying the concentration values of the third column by the maximum evaporator separator capacity of $134,746 \mathrm{~L}$.

The process of developing the nonradionuclide source term involved determining the maximum possible concentration for each nonradionuclide that might be processed in the evaporator vessel and, subsequently, calculating, in kilograms, the total vessel inventory possible for each nonradionuclide. Table $2-3$ is a tabulation of these concentrations.

Table 2-3 was developed from the data presented in Tables 2-4 and 2-5. The "Maximum separator inventory" column in Table 2-3 is the quantity (represented in kilograms) of each particular nonradionuclide constituent that could be present at any one time in the separator. This column was derived by multiplying the maximum concentration value (found in the previous columns) by the maximum evaporator vessel volumetric capacity. The final column in this table lists the CERCLA RQ for each chemical as found in 40 CFR 302.4. If the value in this column is released to the environment during a $24-h$ period, it then becomes reportable under CERCLA.

An asterisk in the "Maximum separator inventory" column denotes that the maximum possible separator inventory for that particular constituent exceeds the CERCLA RQ. 
Table 2-2. Evaporator Separator Nonradionuclide Inventory at Risk.

\begin{tabular}{|l|r|r|r|r|}
\hline \multicolumn{1}{|c|}{ Chemical } & $\begin{array}{c}\text { Constituent } \\
\text { maximum } \\
\text { concen- } \\
\text { tration } \\
(\mathrm{ppb})\end{array}$ & $\begin{array}{c}\text { Constituent } \\
\text { maximum } \\
\text { concen- } \\
\text { tration } \\
(\mathrm{g} / \mathrm{L})\end{array}$ & $\begin{array}{c}\text { Maximum } \\
\text { separator } \\
\text { inventory } \\
(\mathrm{kg})\end{array}$ & $\begin{array}{c}\text { CERCLA } \\
\text { reportable } \\
\text { quantity } \\
(\mathrm{kg})\end{array}$ \\
\hline Cyanide (CN-) & 98,000 & 0.098 & 13.2 & 4.54 \\
\hline Lead & 72,000 & 0.072 & 9.7 & 0.454 \\
\hline Mercury & 16,000 & 0.016 & 2.2 & 0.454 \\
\hline Nickel & 53,000 & 0.053 & 7.1 & 0.454 \\
\hline Phosphorus & $4.9 \mathrm{E}+6$ & 4.9 & 660.3 & 0.454 \\
\hline Sodium & $3.4 \mathrm{E}+8$ & 340 & $45,813.6$ & 4.54 \\
\hline Sodium Fluoride & $1.26 \mathrm{E}+8$ & 126.0 & $16,978.0$ & 454 \\
\hline Sodium Hydroxide & $2.6 \mathrm{E}+8$ & 260.0 & $35,033.96$ & 454 \\
\hline Sodium Nitrite & $3.384 \mathrm{E}+8$ & 338.4 & $45,598.05$ & 45.4 \\
\hline Sodium Phosphate & $8.2 \mathrm{E}+7$ & 82.0 & $11,049.17$ & 2,270 \\
\hline
\end{tabular}


Table 2-3. Evaporator Separator Nonradionuclide Source Term. (4 sheets)

\begin{tabular}{|c|c|c|c|c|}
\hline Chemical & $\begin{array}{l}\text { Constituent } \\
\text { maximum } \\
\text { concen- } \\
\text { tration } \\
\text { (ppb) }\end{array}$ & $\begin{array}{l}\text { Constituent } \\
\text { maximum } \\
\text { concen- } \\
\text { tration } \\
(\mathrm{g} / \mathrm{L})\end{array}$ & $\begin{array}{l}\text { Maximum } \\
\text { separator } \\
\text { inventory } \\
(\mathrm{kg})\end{array}$ & $\begin{array}{c}\text { CERCLA } \\
\text { reportable } \\
\text { quant ity } \\
(\mathrm{kg})\end{array}$ \\
\hline Aluminum & $2.14 E+7$ & 21.4 & $2,883.6$ & no $R Q$ \\
\hline Ammonium hydroxide & $6.77 E+5$ & 0.677 & 91.22 & $45 c_{r}$ \\
\hline $\begin{array}{l}\text { Aluminum oxide } \\
\left(\mathrm{AlO}_{2}-\right)\end{array}$ & $5.8 E+7$ & 58 & $7,815.3$ & no $R Q$ \\
\hline Ammonium & $5.36 E+6$ & 5.36 & 722.2 & no $R Q$ \\
\hline Barium & 82,400 & 0.0824 & 11.1 & 454 \\
\hline Boron & $1.04 E+5$ & 0.104 & 14.0 & no $R Q$ \\
\hline Calcium & $1.46 E+6$ & 1.46 & 196.7 & no $R Q$ \\
\hline Cadmium & 16,000 & 0.0160 & 2.16 & 4.54 \\
\hline Carbonate $\left(\mathrm{CO}_{3}\right)$ & $2.95 E+7$ & 29.5 & $3,975.0$ & no $\mathrm{RQ}$ \\
\hline Chloride $(\mathrm{Cl}-)$ & $9.6 \mathrm{E}+6$ & 9.6 & $1,293.6$ & no $\mathrm{RQ}$ \\
\hline Chromium & $8.5 E+5$ & 0.85 & 114.5 & 2,270 \\
\hline Copper & $4.71 E+6$ & 4.71 & 634.7 & 2,270 \\
\hline Cyanide ( $\mathrm{CN}-)$ & 98,000 & 0.098 & $13.2^{\star}$ & 4.54 \\
\hline Fluoride (F-) & $3.67 E+7$ & 36.7 & $4,945.2$ & no $R Q$ \\
\hline Hydroxide $(\mathrm{OH}-)$ & $9.9 E+7$ & 99.0 & $13,339.9$ & no $R Q$ \\
\hline Iron & 70,000 & 0.07 & 9.4 & no $R Q$ \\
\hline Lead & 72,000 & 0.072 & $9.7 *$ & 0.454 \\
\hline Magnesium & 29,000 & 0.029 & 3.9 & no $R Q$ \\
\hline Manganese & 29,000 & 0.029 & 3.9 & no $R Q$ \\
\hline Mercury & 16,000 & 0.016 & $2.2 *$ & 0.454 \\
\hline Molybdenum & 88,000 & 0.088 & 11.9 & no $R Q$ \\
\hline Nickel & 53,000 & 0.053 & $7.1 *$ & 0.454 \\
\hline Nitrate $\left(\mathrm{NO}_{3}-\right)$ & $2.9 E+8$ & 290 & 39,076 & no $R Q$ \\
\hline Nitrite $\left(\mathrm{NO}_{2}-\right)$ & $8.4 E+7$ & 84 & $11,318.7$ & no $\mathrm{RQ}$ \\
\hline Phosphate $\left(\mathrm{PO}_{4}\right)$ & $2.96 \mathrm{E}+7$ & 29.7 & $3,988.5$ & no $R Q$ \\
\hline Phosphorus & $4.9 E+6$ & 4.9 & $660.3 *$ & 0.454 \\
\hline Potassium & $4.04 E+7$ & 40.4 & $5,443.7$ & no $R Q$ \\
\hline
\end{tabular}


Table 2-3. Evaporator Separator Nonradionuclide Source Term. (4 sheets)

\begin{tabular}{|c|c|c|c|c|}
\hline Chemical & $\begin{array}{c}\text { Constituent } \\
\text { maximum } \\
\text { concen- } \\
\text { tration } \\
\text { (ppb) }\end{array}$ & $\begin{array}{c}\text { Constituent } \\
\text { maximum } \\
\text { concen- } \\
\text { tration } \\
(\mathrm{g} / \mathrm{L})\end{array}$ & $\begin{array}{l}\text { Maximum } \\
\text { separator } \\
\text { inventory } \\
(\mathrm{kg})\end{array}$ & $\begin{array}{c}\text { CERCLA } \\
\text { reportable } \\
\text { quant ity } \\
(\mathrm{kg})\end{array}$ \\
\hline Silicon & $2.71 E+9$ & 2,710 & $365,161.7$ & no $\mathrm{RQ}$ \\
\hline Sodium & $3.4 E+8$ & 340 & $45,813.6 *$ & 4.54 \\
\hline Sodium aluminate & $2.049 E+8$ & 204.9 & $27,609.46$ & no $R Q$ \\
\hline Sodium carbonate & $2.438 E+8$ & 243.8 & $32,851.07$ & no $R Q$ \\
\hline Sodium chloride & $7.5 E+5$ & 0.705 & 95.0 & no $R Q$ \\
\hline Sodium fluoride & $1.26 E+8$ & 126.0 & $16,978.0 *$ & 454 \\
\hline Sodium hydroxide & $2.6 E+8$ & 260.0 & $35,033.96^{\star}$ & 454 \\
\hline Sodium nitrate & $3.57 E+8$ & 357.0 & $48,104.32$ & no $\mathrm{RQ}$ \\
\hline Sodium nitrite & $3.384 E+8$ & 338.4 & $45,598.05^{*}$ & 45.4 \\
\hline Sodium phosphate & $8.2 E+7$ & 82.0 & $11,049.17^{\star}$ & 2,270 \\
\hline Sodium sulfate & $4.2 E+7$ & 42.6 & $5,740.18$ & no $\mathrm{RQ}$ \\
\hline Sulfate $\left(\mathrm{SO}_{4}\right)$ & $7.94 E+6$ & 7.94 & $1,069.9$ & no $\mathrm{RQ}$ \\
\hline Tungsten & $2.1 E+5$ & 0.21 & 28.3 & no $R Q$ \\
\hline Uranium & $1.2 E+5$ & 0.12 & 16.2 & 45.4 \\
\hline Zinc & $1.68 E+5$ & 0.168 & 22.6 & 454 \\
\hline Acetone & 2,100 & 0.0021 & 0.28 & 2,270 \\
\hline $\begin{array}{l}\text { Alkyl, } \\
\text { hydroxymethylbenzene }\end{array}$ & 1,800 & 0.0018 & 0.24 & no $R Q$ \\
\hline Butanedioic acid & $4.2 \mathrm{E}+5$ & 0.42 & 56.6 & no $\mathrm{RQ}$ \\
\hline C3-Alkylbenzene & $3.2 \mathrm{E}+5$ & 0.32 & 43.1 & no $\mathrm{RQ}$ \\
\hline $\begin{array}{l}\text { Chloroethyl, } \\
\text { 2-hydroxymetisyl, BA }\end{array}$ & 13,000 & 0.013 & 1.8 & no $R Q$ \\
\hline $\begin{array}{l}\text { 2-Chloromethylhydroxy- } \\
\text { methylbenzene }\end{array}$ & 12,000 & 0.012 & 1.6 & no $R Q$ \\
\hline 2-ChToromethyloxylene & 6,600 & 0.0066 & 0.89 & no $R Q$ \\
\hline Citric acid & 53,000 & 0.053 & 7.14 & no $R Q$ \\
\hline Diethylphthalates & 6,600 & 0.0066 & 0.89 & 454 \\
\hline Dimethyltoluidine & 12,000 & 0.012 & 1.6 & no $\mathrm{RQ}$ \\
\hline Dioctylphthalate & 24,000 & 0.024 & 3.23 & no $\mathrm{RQ}$ \\
\hline
\end{tabular}


Table 2-3. Evaporator Separator Nonradionuclide Source Term. (4 sheets)

\begin{tabular}{|l|r|r|r|r|}
\hline \multicolumn{1}{|c|}{ Chemical } & $\begin{array}{c}\text { Constituent } \\
\text { maximum } \\
\text { concen- } \\
\text { tration } \\
(\mathrm{ppb})\end{array}$ & $\begin{array}{c}\text { Constituent } \\
\text { maximum } \\
\text { concen- } \\
\text { tration } \\
(\mathrm{g} / \mathrm{L})\end{array}$ & $\begin{array}{c}\text { Maximum } \\
\text { separator } \\
\text { inventory } \\
\text { (kg) }\end{array}$ & $\begin{array}{c}\text { CERCLA } \\
\text { reportable } \\
\text { quant ity } \\
\text { (kg) }\end{array}$ \\
\hline Dodecane & 4,000 & 0.004 & 0.54 & no RQ \\
\hline $\begin{array}{l}\text { Dodecanoic } \\
\text { acid }\end{array}$ & 950 & 0.00095 & 0.13 & no RQ \\
\hline Ethanedioic acid & $4.2 \mathrm{E}+6$ & 4.2 & 565.93 & no RQ \\
\hline $\begin{array}{l}\text { Ethyl, } \\
\text { 2-methylhydroxymethyl- } \\
\text { benzenes }\end{array}$ & 64,000 & 0.064 & 8.6 & no RQ \\
\hline Ethylbenzaldahyde & $6.9 \mathrm{E}+5$ & 0.69 & 92.97 & no RQ \\
\hline ED3A & 18,000 & 0.018 & 2.4 & no RQ \\
\hline EDTA & 85,000 & 0.085 & 11.5 & 2,270 \\
\hline Ethylxylene & 320 & 0.00032 & 0.043 & no RQ \\
\hline Heptadecanoic acid & 2,400 & 0.0024 & 0.32 & no RQ \\
\hline Heptanedioic acid & 27,000 & 0.027 & 3.6 & no RQ \\
\hline Hexadecanoic acid & 830 & 0.00083 & 0.11 & no RQ \\
\hline Hexanedioic acid & 64,000 & 0.064 & 8.6 & no RQ \\
\hline Hexanoic acid & 43,000 & 0.043 & 5.8 & no RQ \\
\hline Hydroxyacetic acid & 46,000 & 0.046 & 6.2 & no RQ \\
\hline $\begin{array}{l}\text { 2-Hydroxymethyl- } \\
\text { benzoic acid }\end{array}$ & 27,000 & 0.027 & 3.6 & no RQ \\
\hline Methylbenzaldahyde & $6.9 \mathrm{E}+5$ & 0.69 & 92.97 & no RQ \\
\hline 2-Methylbenzoic acid & 18,000 & 0.018 & 2.4 & no RQ \\
\hline $\begin{array}{l}\text { 2-Methyl, } \\
\text { hydroxymethyl benzene }\end{array}$ & $3.5 \mathrm{E}+5$ & 0.35 & 47.2 & no RQ \\
\hline Methyltoluidine & 3,500 & 0.0035 & 0.47 & no RQ \\
\hline $\begin{array}{l}\text { n-C22H46 } \\
\text { C40H82 }\end{array}$ & 20,000 & 0.02 & 2.7 & no RQ \\
\hline HEDTA & 20,000 & 0.02 & 2.7 & no RQ \\
\hline MAIDA & $5.8 E+5$ & 0.58 & 78.2 & no RQ \\
\hline MICEDA & 30,000 & 0.03 & 4.04 & no RQ \\
\hline Nitrilotriacetic acid & 7,500 & 0.0075 & 1.01 & 2,270 \\
\hline
\end{tabular}


Table 2-3. Evaporator Separator Nonradionuclide Source Term. (4 sheets)

\begin{tabular}{|c|c|c|c|c|}
\hline Chemical & $\begin{array}{c}\text { Constituent } \\
\text { maximum } \\
\text { concen- } \\
\text { tration } \\
\text { (ppb) }\end{array}$ & $\begin{array}{l}\text { Constituent } \\
\text { maximum } \\
\text { concen- } \\
\text { tration } \\
(\mathrm{g} / \mathrm{L})\end{array}$ & $\begin{array}{l}\text { Maximum } \\
\text { separator } \\
\text { inventory } \\
(\mathrm{kg})\end{array}$ & $\begin{array}{c}\text { CERCLA } \\
\text { reportable } \\
\text { quant ity } \\
(\mathrm{kg})\end{array}$ \\
\hline Octodecanoic acid & 410 & 0.00041 & 0.055 & no $R Q$ \\
\hline Pentadecane & 3,700 & 0.0037 & 0.5 & no $R Q$ \\
\hline Pentadecanoic acid & 35,000 & 0.035 & 4.7 & no $R Q$ \\
\hline Pentanedioic acid & 70,000 & 0.07 & 9.4 & no $R Q$ \\
\hline Propylbenzene & 1,800 & 0.0018 & 0.24 & no $R Q$ \\
\hline Tetradecane & 9,000 & 0.009 & 1.2 & no $R Q$ \\
\hline Tetrahydrofuran & 27 & $2.7 E-5$ & 0.0036 & 454 \\
\hline Tributyl phosphate & 27,000 & 0.027 & 3.6 & no $R Q$ \\
\hline $\begin{array}{l}\text { Trinbutyl(diol)- } \\
\text { phosphate }\end{array}$ & 11,000 & 0.011 & 1.5 & no $R Q$ \\
\hline Tridecane & 15,000 & 0.015 & 2.02 & no RQ \\
\hline $\begin{array}{l}\text { 1,3,5 Trimethyl } \\
\text { benzene }\end{array}$ & 78,000 & 0.078 & 10.5 & no $\mathrm{RQ}$ \\
\hline Undecane & 3,300 & 0.0033 & 0.44 & no $R Q$ \\
\hline Unknown phthalates & 21,000 & 0.021 & 2.8 & no $R Q$ \\
\hline
\end{tabular}


Table 2-4. Evaporator Separator Nonradionuclide Data.

\begin{tabular}{|c|c|c|c|c|c|c|c|}
\hline \multirow[t]{3}{*}{ Compound } & \multirow[t]{3}{*}{$\begin{array}{c}\text { Chemical } \\
\text { formula }\end{array}$} & $\begin{array}{l}\text { Evaporator } \\
\text { feed } \\
\text { concen- } \\
\text { tration }\end{array}$ & $\begin{array}{l}\text { slurry } \\
\text { feed } \\
\text { concen- } \\
\text { tration } \\
\end{array}$ & $\begin{array}{l}\text { slurry } \\
\text { feed } \\
\text { maximum } \\
\text { concen- } \\
\text { tration } \\
\star \star\end{array}$ & $\begin{array}{l}\text { Average } \\
\text { evaporator } \\
\text { feed } \\
\text { concen- } \\
\text { tration*** }\end{array}$ & $\begin{array}{l}\text { Maximum } \\
\text { evaporator } \\
\text { feed } \\
\text { concen- } \\
\text { tration }\end{array}$ & $\begin{array}{l}\text { Maximum } \\
\text { separator } \\
\text { inventory }\end{array}$ \\
\hline & & \multirow{2}{*}{ (M) } & (M) & (M) & \multirow{2}{*}{$(g / L)$} & \multirow{2}{*}{$(g / L)$} & \multirow{2}{*}{$(\mathrm{kg})$} \\
\hline & & & $(g / L)$ & $(g / L)$ & & & \\
\hline Sodium chloride & & & & & 0.705 & 0.705 & 95.0 \\
\hline \multirow{2}{*}{$\begin{array}{l}\text { Sodium } \\
\text { hydroxide }\end{array}$} & \multirow[t]{2}{*}{$\mathrm{NaOH}$} & \multirow[t]{2}{*}{3.9} & 5.5 & 6.5 & \multirow[t]{2}{*}{15.5} & \multirow[t]{2}{*}{260.0} & \multirow[t]{2}{*}{35.033 .96} \\
\hline & & & & 260.0 & & & \\
\hline \multirow[t]{2}{*}{ Sodium nitrate } & \multirow[t]{2}{*}{$\mathrm{NaNO}_{3}$} & \multirow[t]{2}{*}{2.8} & 4.0 & 4.2 & \multirow[t]{2}{*}{38.2} & \multirow[t]{2}{*}{357.0} & \multirow[t]{2}{*}{$48,104.32$} \\
\hline & & & & 357.0 & & & \\
\hline \multirow[t]{2}{*}{ Sodium nitrite } & \multirow[t]{2}{*}{$\mathrm{NaNO}_{2}$} & \multirow[t]{2}{*}{1.8} & 2.5 & 4.9 & \multirow[t]{2}{*}{9.58} & \multirow[t]{2}{*}{338.4} & \multirow[t]{2}{*}{$45,598.05$} \\
\hline & & & & 338.4 & & & \\
\hline \multirow{2}{*}{$\begin{array}{l}\text { Sodium } \\
\text { aluminate }\end{array}$} & \multirow[t]{2}{*}{$\mathrm{NaAlO}_{2}$} & \multirow[t]{2}{*}{1.8} & 2.5 & 2.5 & & \multirow[t]{2}{*}{204.9} & \multirow[t]{2}{*}{$27,609.46$} \\
\hline & & & & 204.9 & & & \\
\hline \multirow{2}{*}{$\begin{array}{l}\text { Sodium } \\
\text { carbonate }\end{array}$} & \multirow[t]{2}{*}{$\mathrm{Na}_{2} \mathrm{CO}_{3}$} & \multirow[t]{2}{*}{0.7} & 0.9 & 2.3 & & \multirow[t]{2}{*}{243.8} & \multirow[t]{2}{*}{$32,851.07$} \\
\hline & & & & 243.8 & & & \\
\hline Sodium sulfate & $\mathrm{Na}_{2} \mathrm{SO}_{4}$ & 0.2 & 0.3 & & & 42.6 & $5,740.18$ \\
\hline & & & 42.6 & & & & \\
\hline Sodium & $\mathrm{Na}_{3} \mathrm{PO}_{4}$ & 0.5 & 0.15 & 0.5 & 0.589 & 82.0 & $11,049.17$ \\
\hline phosphiate & & & & 82.0 & & & \\
\hline Ammonia & $\mathrm{NH}_{3}$ & 0.11 & 0.1 & 0.1 & & 1.7 & 229.07 \\
\hline & & & & 1.7 & & & \\
\hline $\begin{array}{l}\text { Ammonium } \\
\text { hydroxide }\end{array}$ & $\mathrm{NH}_{4} \mathrm{OH}$ & & & & 0.677 & 0.677 & 91.22 \\
\hline Sodium fluoride & $\mathrm{NaF}$ & 0.07 & 0.1 & 3.0 & 3.45 & 126.0 & $16,978.0$ \\
\hline & & & & 126.0 & & & \\
\hline
\end{tabular}

NOTE: \#HHC-SD-WM-SAR-023, 242-A Evaporator Safety Analysis Report (WHC 1988a)

**WHC-SD-WM-PSE-008, 242-A Evaporator Hazard Classification (WHC 1991b)

*\#DE/RL-90-42, Rev. 0, 242-A Evaporator Dangerous Waste Permit

Application, Table 3-5 (DOE-RL 1990). 
WHC-EP-0466-1

Table 2-5. Evaporator Separator Nonradionuclide Data. (4 sheets)

\begin{tabular}{|c|c|c|c|c|c|}
\hline $\begin{array}{c}\text { (1) } \\
\text { Chemical }\end{array}$ & $\begin{array}{c}\text { (2) } \\
\text { Evaporator } \\
\text { feed } \\
\text { concen-tration } \\
\text { (ppb) }\end{array}$ & $\begin{array}{c}\text { (3) } \\
\text { Evaporator } \\
\text { slurry } \\
\text { concen- } \\
\text { tration } \\
\text { (ppb) }\end{array}$ & $\begin{array}{c}(4) \\
A N-103 \\
D S S \\
(\mathrm{ppb})\end{array}$ & $\begin{array}{c}(5) \\
A N-106 \\
\text { DSSF } \\
\text { (ppb) }\end{array}$ & $\begin{array}{c}(6) \\
\text { AW-101 } \\
\text { DSSF } \\
(\mathrm{ppb})\end{array}$ \\
\hline Aluminum & $2.14 E+7$ & $2.07 E+7$ & & & \\
\hline Aluminum oxide & & & $5.8 E+7$ & $1.1 E+7$ & $2.6 E+7$ \\
\hline Ammonium & $5.36 E+6$ & $5.70 E+5$ & & & \\
\hline Barium & & 82,400 & & & 14,000 \\
\hline Boron & 18,400 & $1.04 E+5$ & & 17,000 & \\
\hline Calcium & $2.67 E+5$ & $1.46 E+6$ & 86,000 & 67,000 & 65,000 \\
\hline Cadmium & & & 16,000 & & \\
\hline Carbonate & $2.19 E+7$ & $2.95 E+7$ & $9 E+6$ & $2.3 E+7$ & $5.1 E+6$ \\
\hline $\begin{array}{l}\text { Chloride } \\
\text { (Cl-) }\end{array}$ & $4.38 E+6$ & $5.13 E+6$ & $9.6 E+6$ & $2.9 E+6$ & $6.8 E+6$ \\
\hline Chromium & $1.61 E+5$ & $1.92 E+5$ & $8.5 E+5$ & $6.1 E+5$ & $3.5 E+5$ \\
\hline Copper & $4.71 E+6$ & 58,600 & 12,000 & 1,800 & \\
\hline $\begin{array}{l}\text { Cyanide } \\
(\mathrm{CN}-)\end{array}$ & & & 34,000 & 13,000 & 98,000 \\
\hline Fluoride (F-) & $1.86 E+7$ & $3.67 \mathrm{E}+7$ & $7.4 E+5$ & 34,000 & \\
\hline Hydroxide $(\mathrm{OH}-)$ & 65,900 & $7.72 \mathrm{E}+7$ & $9.8 E+7$ & $1.2 E+7$ & $9.9 E+7$ \\
\hline Iron & 65,900 & 15,900 & 70,000 & 9,400 & 39,000 \\
\hline Lead & & & 72,000 & & 68,000 \\
\hline Magnesium & 7,330 & 15,300 & 29,000 & & \\
\hline Manganese & & & 29,000 & & \\
\hline
\end{tabular}


WHC-EP-0466-1

Table 2-5. Evaporator Separator Nonradionuclide Uata. (4 sheets)

\begin{tabular}{|c|c|c|c|c|c|}
\hline $\begin{array}{l}(1) \\
\text { Chemical }\end{array}$ & $\begin{array}{c}\text { (2) } \\
\text { Evaporator } \\
\text { feed } \\
\text { concen-tration } \\
\text { (ppb) }\end{array}$ & $\begin{array}{c}\text { (3) } \\
\text { Evaporator } \\
\text { slurry } \\
\text { concen- } \\
\text { tration } \\
\text { (ppb) }\end{array}$ & $\begin{array}{c}(4) \\
\text { AN-103 } \\
\text { DSS } \\
(\mathrm{ppb})\end{array}$ & $\begin{array}{c}(5) \\
A N-106 \\
D S S F \\
(\mathrm{ppb})\end{array}$ & $\begin{array}{c}(6) \\
A W-101 \\
D S S F \\
(p p b)\end{array}$ \\
\hline Mercury & & & 16,000 & & 35 \\
\hline Molybdenum & & & 88,000 & 32,000 & 60,000 \\
\hline Nickel & & & & 53,000 & 27,000 \\
\hline Nitrate $\left(\mathrm{NO}_{3}{ }^{-}\right)$ & $1.36 E+8$ & $2.03 E+8$ & $1.6 E+8$ & $7.9 \mathrm{E}+7$ & $2.9 E+8$ \\
\hline Nitrite $\left(\mathrm{NO}_{2}{ }^{-}\right)$ & $7.79 E+7$ & $6.12 \mathrm{E}+7$ & $1.4 E+8$ & $3.4 E+7$ & $8.4 E+7$ \\
\hline Phosphate $\left(\mathrm{PO}_{4}-\right)$ & $3.17 E+6$ & $2.96 E+7$ & $9.3 E+5$ & $1.4 E+7$ & $8.9 E+5$ \\
\hline Phosphoris & $6.92 E+5$ & $8.10 E+5$ & & $4.9 E+6$ & \\
\hline Potassium & $4.04 E+7$ & $2.68 E+7$ & $1.5 E+7$ & 1.2 & $3.9 E+7$ \\
\hline Silicon & $1.36 E+5$ & $2.71 E+9$ & $2.7 E+5$ & & $1.1 E+5$ \\
\hline Sodium & $1.45 \mathrm{E}+8$ & $1.77 \mathrm{E}+8$ & $3.4 E+8$ & 1.?E+8 & $2.6 E+C$ \\
\hline sulfate $\left(\mathrm{SO}_{4}^{-}\right)$ & $7.94 E+6$ & $6.63 E+6$ & $1.6 E+6$ & $2.9 E+6$ & $4.2 E+6$ \\
\hline Tungsten & & & $2.1 E+5$ & & \\
\hline Uranium & & & $1.2 E+5$ & 14,000 & 92,000 \\
\hline Zinc & 16,900 & $1.68 E+5$ & 48,000 & & \\
\hline $\begin{array}{l}\text { Alkyl, } \\
\text { hydroxymethyl benzene }\end{array}$ & & & 1,800 & & \\
\hline Butanedioic acid & & & $4.2 E+5$ & & \\
\hline C3-Alkylben?ene & & & $3.2 E+5$ & & \\
\hline $\begin{array}{l}\text { Chroroethy } 1, \\
2 \text {-hydroxymethy } 1, B A\end{array}$ & & & 13,000 & & \\
\hline $\begin{array}{l}\text { 2-Chloromethylhydroxy- } \\
\text { methylbenzene }\end{array}$ & & & 12,000 & & \\
\hline 2-Chloromethyloxylene & & & 6,600 & & \\
\hline Citric acid & & & 18,000 & 32,000 & 53,000 \\
\hline Diethylphthalates & & & & & 6600 \\
\hline Dimethyltoiuidine & & & 12,000 & & \\
\hline Dioctylphthalate & & & 24,000 & & 1,800 \\
\hline Dodecane & & & 4,000 & & 1,700 \\
\hline
\end{tabular}


WHC-EP-0466-1

Table 2-5. Evaporator Separator Nonradionuclide Data. (4 sheets)

\begin{tabular}{|c|c|c|c|c|c|}
\hline $\begin{array}{c}\text { (1) } \\
\text { Chemical }\end{array}$ & $\begin{array}{c}\text { (2) } \\
\text { Evaporator } \\
\text { feed } \\
\text { concen-tration } \\
\text { (ppb) }\end{array}$ & $\begin{array}{c}(3) \\
\text { Evaporator } \\
\text { slurry } \\
\text { concen- } \\
\text { tration } \\
\text { (ppb) }\end{array}$ & $\begin{array}{l}(4) \\
\text { AN-103 } \\
\text { DSS } \\
\text { (ppb) }\end{array}$ & $\begin{array}{l}(5) \\
\text { AN-106 } \\
\text { DSSF } \\
(\mathrm{ppb})\end{array}$ & $\begin{array}{l}(6) \\
A W-101 \\
D S S F \\
(\mathrm{ppb})\end{array}$ \\
\hline $\begin{array}{l}\text { Dodecanoic } \\
\text { acid }\end{array}$ & & & & & 950 \\
\hline Ethanewioic acid & & & $4.2 E+6$ & & \\
\hline $\begin{array}{l}\text { Ethyl, 2-methylhydroxy- } \\
\text { methyibenzenes }\end{array}$ & & & 64,000 & & \\
\hline Ethylbenzaldahyde & & & $6.9 E+5$ & & \\
\hline ED3A & & & 4,800 & & 18,000 \\
\hline EDTA & & & 85,000 & 4,800 & 11,000 \\
\hline Ethylxylene & & & 320 & & \\
\hline Heptadecanoic acid & & & 2,400 & & \\
\hline Heptanedioic acid & & & 27,000 & & \\
\hline Hexadecanoic acid & & & & & 830 \\
\hline Hexanedioic acid & & & 64,000 & & 7,100 \\
\hline Hexanoic acid & & & 43,000 & & \\
\hline Hydroxyacetic acid & & & & 46,000 & \\
\hline $\begin{array}{l}\text { 2-Hydroxymethylbenzoic } \\
\text { acid }\end{array}$ & & . & 27,000 & • & \\
\hline Methylbenzaldahyde & & & $6.9 E+5$ & & \\
\hline 2-Methylbenzoic acid & & & 18,000 & & \\
\hline $\begin{array}{l}\text { 2-Methyl, } \\
\text { hydroxymethylbenzene }\end{array}$ & & & $3.5 E+5$ & & \\
\hline Methyltoluidine & & & 3,500 & & \\
\hline $\begin{array}{l}\mathrm{n}-\mathrm{C} 22 \mathrm{H} 46 \\
\mathrm{C} 4 \mathrm{OH} 82\end{array}$ & & & 15,000 & & 20,000 \\
\hline HEDTA & & & & 20,000 & \\
\hline MAIDA & & & $5.8 E+5$ & & \\
\hline MICEDA & & & 30,000 & & \\
\hline Nitrilotriacetic acid & & & 4,600 & & 7,500 \\
\hline Octodecanoic acid & & & & & 410 \\
\hline Pentadecane & & & 3,700 & & 800 \\
\hline
\end{tabular}


Table 2-5. Evaporator Separator Nonradionuclide Data. (4 sheets)

\begin{tabular}{|l|r|r|r|r|r|}
\hline \multicolumn{1}{|c|}{$\begin{array}{c}\text { Chemical } \\
\text { Chentadecanoic acid }\end{array}$} & $\begin{array}{c}\text { (2) } \\
\text { Evaporator } \\
\text { feed } \\
\text { concen-tration } \\
\text { (ppb) }\end{array}$ & $\begin{array}{c}\text { (3) } \\
\text { Evaporator } \\
\text { slurry } \\
\text { concen- } \\
\text { tration } \\
\text { (ppb) }\end{array}$ & $\begin{array}{c}\text { (4) } \\
\text { AN-103 } \\
\text { DSS } \\
\text { (ppb) }\end{array}$ & $\begin{array}{c}\text { (5) } \\
\text { AN-106 } \\
\text { DSF } \\
\text { (ppb) }\end{array}$ & $\begin{array}{c}\text { AW-101 } \\
\text { DSSF } \\
\text { (ppb) }\end{array}$ \\
\hline Pentanedioic acid & & & 35,000 & & \\
\hline Propylbenzene & & & 70,000 & & 7,400 \\
\hline Tetradecane & & 530 & 18,000 & & 27,000 \\
\hline Tetrahydrofuran & & & 11,000 & & \\
\hline Tributyl phosphate & & & 15,000 & & 14,000 \\
\hline $\begin{array}{l}\text { Trinbutyl (diol) } \\
\text { phosphate }\end{array}$ & & & 78,000 & & \\
\hline Tridecane & & 580 & & 3,300 \\
\hline $1,3,5$ Trimethylbenzene & & & 21,000 & & 5,400 \\
\hline Undecane & & & & & \\
\hline Unknown phthalates & & & & & \\
\hline
\end{tabular}


Tables 2-4 and 2-5 present the data that were used to develop Table 2-3. Tables 2-4 and 2-5 were generated from available data. The data in Table 2-4 were gathered from the sources referenced below and identified in the column headers by the number of asterisks (*).

*WHC-SD-WM-SAR-023, 242-A Evaporator Safety Analysis Report (WHC 1988a)

**WHC-SD-WM-PSE-008, 242-A Evaporator Hazard Classification (WHC 1991b)

***DOE/RL-90-42, Rev.0, 242-A Evaporator Dangerous Waste Permit

Application, Table 3-5 (DOE-RL 1990).

The "Maximum separator inventory" column of Table 2-4 contains the maximum concentration of the particular tabulated chemicals that could potentially be present within the evaporator vessel. The method used to determine this maximum concentration is as follows.

1. The maximum concentration values of the constituents in the evaporator and slurry feeds were determined and expressed in units of molarity* (M). These values are listed in columns 3,4 , and 5 of Table 2-4.

2. These values, in turn, were converted to units of grams per liter $(\mathrm{g} / \mathrm{L})$ and specified under the corresponding molar value in that column for the particular constituent. Molarity is converted to grams per liter $(\mathrm{g} / \mathrm{L})$ by multiplying the value expressed in molar units by the molecular weight of the chemical.

3. These $g / L$ values were compared to the $g / L$ values in the next column entitled "Average evaporator feed concentration."

4. The largest of these values were then tabulated in column 7 , entitled "Maximum evaporator feed concentration."

5. The values listed in the column entitled "Maximum separator inventory" were obtained by multiplying the value in column 7 by the maximum volumetric capacity $(134,746 \mathrm{~L})$ of the evaporator separator vessel and then dividing the resulting value by 1,000 to convert the resultant answer to kilograms.

Table 2-5 lists other chemical constituent concentration data for the evaporator feed and slurry. These values are expressed in concentration units of parts-per-billion** (ppb). The values in Columns 2 and 3 of this table were obtained from those 1isted in DOE/RL-90-42, Rev.0, 242-A Evaporator Dangerous Waste Permit Application, Tables 3-2 and 3-6 (DOE-RL 1990). The

*The "M" stands for Molar which is actually one mole of a substance per liter. A mole is defined as the quantity of a substance having a mass in grams equal to its molecular weight.

**If the solution is dilute, it can be assumed that the specific gravity of the solution is 1 . If this is assumed, $a \mathrm{~g} / \mathrm{L}$ is equal to $1,000,000 \mathrm{ppb}$. 
final three columns are values obtained from Internal Memo 29510-091-002, from Evaporator Restart SAR Development, dated March 1, 1991, subject: Normal Operating Source Term For The 242-A Evaporator, Tables 4 and 5 (WHC 1991C).

\subsubsection{Process Condensate Nonradiological Potential Source Terms}

Certain chemicals (referred to as nonradionuclides in this FEMP) are reportable under the CERCLA if any one regulated material (chemical) that is discharged or released over a $24-h$ period from a facility exceeds $100 \%$ of the $R Q$ as 7 isted in 40 CFR 302.4 (EPA 1991c). To ascertain if there is a potential for any such discharges or releases, it was first determined which chemicals are present in measurable quantities in the separator vessel. The tabulation of these chemicals is called an "inventory at risk" and is presented in Table 2-6. Table 2-6 lists those constituents that could become reportable under CERCLA if released to the environment. This table was derived from, and is an extract from, the nonradionuclide source term presented in Table 2-7. Note, the third column of Table 2-6 shows that if the entire contents in a completely full process condensate tank $\mathrm{C}-100 \quad(17,800 \mathrm{gal}$ or $67,373 \mathrm{~L}$ ) were to be released, only ammonia would become reportable. However, the fifth column shows that if the evaporator process were operating at the maximum process condensate generation rate of $227 \mathrm{~L} / \mathrm{min}(60 \mathrm{ga} / \mathrm{min})$, and if this entire volume were to be released within a 24-h period, phosphorus and sodium would also become reportable.

Table 2-6. Process Condensate Nonradionuciide Inventory at Risk.

\begin{tabular}{|l|r|r|r|r|}
\hline \multicolumn{1}{|c|}{ Chemical } & $\begin{array}{c}\text { Maximum } \\
\text { concentration } \\
(\mathrm{ppb})\end{array}$ & $\begin{array}{c}\text { Maximum } \\
\mathrm{C}-100 \\
\text { inventory } \\
(\mathrm{kg})\end{array}$ & $\begin{array}{c}\text { CERCLA } \\
\text { Reportable } \\
\text { quantity } \\
(\mathrm{kg})\end{array}$ & $\begin{array}{c}\text { Maximum } \\
\text { quantity } \\
\text { per day } \\
(\mathrm{kg})\end{array}$ \\
\hline Ammonia & $2.19 \mathrm{E}+6$ & $147.55^{*}$ & 45.4 & $716.2^{*}$ \\
\hline Phosphorus & 6,195 & 0.4174 & 0.454 & $2.0259^{*}$ \\
\hline Sodium & 51,497 & 3.4695 & 4.54 & $16.8408^{*}$ \\
\hline
\end{tabular}

The process of developing the nonradionuclide source term involved the determining the maximum possible concentration for each nonradionuclide that might be processed in the evaporator vessel and, subsequently, calculating the total vessel inventory (in kilograms) possible for each nonradionuclide. Table 2-7 is a tabulation of these concentrations.

Table 2-7 tabulates the maximum concentrations of the listed constituents from the data tabulated in Table 2-8 and compares these values to the CERCLA $R Q$ value. The columns in Table 2-7 are defined as follows.

The "Maximum concentration" column is the maximum concentration of the constituent listed in each row of Table 2-8. Note that the unit ppb is used in this column. It is assumed that the solution is dilute, thus it can be assumed that the specific gravity of the solution is 1 . 
Table 2-7. Process Condensate Nonradionuclide Source Term. (4 sheets)

\begin{tabular}{|c|c|c|c|c|}
\hline Chemical & $\begin{array}{l}\text { Maximum } \\
\text { concen- } \\
\text { tration } \\
(p p b)\end{array}$ & $\begin{array}{l}\text { Maximum } \\
\text { C-100 } \\
\text { inventory } \\
(\mathrm{kg})\end{array}$ & $\begin{array}{c}\text { CERCLA } \\
\text { Reportable } \\
\text { quant ity } \\
(\mathrm{kg})\end{array}$ & $\begin{array}{l}\text { Maximum } \\
\text { quantity } \\
\text { per day } \\
(\mathrm{kg})\end{array}$ \\
\hline Aluminum & 4,992 & 0.336 & no $R Q$ & 1.633 \\
\hline Ammonium & $9.35 E+6$ & 629.9 & no $\mathrm{RQ}$ & $3,057.7$ \\
\hline Ammonia & $2.19 E+6$ & $147.55 *$ & 45.4 & $716.2^{*}$ \\
\hline Arsenic (EP toxic) & 50 & 0.0034 & 0.454 & 0.0164 \\
\hline Barium (EP toxic) & 232 & 0.0156 & 454 & 0.0759 \\
\hline Barium & 8 & 0.0005 & 454 & 0.0026 \\
\hline Boron & 151 & 0.0102 & no $\mathrm{RQ}$ & 0.0494 \\
\hline Cadmium & 10 & 0.0007 & 4.54 & 0.0033 \\
\hline Calcium & 8,320 & 0.5605 & no $\mathrm{RQ}$ & 2.7208 \\
\hline Carbonate & $7.5 E+5$ & 50.53 & no $\mathrm{RQ}$ & 245.268 \\
\hline Chloride & 2,300 & 0.1550 & no $\mathrm{RQ}$ & 0.7522 \\
\hline Chromium & 156 & 0.0105 & 2,270 & 0.0510 \\
\hline Copper & 127 & 0.0086 & 2,270 & 0.0415 \\
\hline Fluoride (IC) & 2,100 & 0.1415 & no $\mathrm{RQ}$ & 0.6868 \\
\hline Fluoride (IS E) & 65 & 0.0044 & no $R Q$ & 0.0213 \\
\hline Fluoride & 12,273 & 0.8269 & no $R Q$ & 4.0136 \\
\hline Iron & 503 & 0.0339 & no $\mathrm{RQ}$ & 0.1645 \\
\hline Lead & 50 & 0.0034 & 0.454 & 0.0164 \\
\hline Magnesium & 4,030 & 0.2715 & no $\mathrm{RQ}$ & 1.3179 \\
\hline Manganese & 5 & 0.0003 & no $R Q$ & 0.0016 \\
\hline Mercury (EP toxic) & 10 & 0.0007 & 0.454 & 0.0033 \\
\hline Mercury & 0.7 & $4.7 E-5$ & 0.454 & 0.0002 \\
\hline Nickel & 17 & 0.0011 & 0.454 & 0.0056 \\
\hline Nitrate & 5,000 & 0.3369 & no $R Q$ & 1.6351 \\
\hline Phosphorus & 6,195 & 0.4174 & 0.454 & $2.0259 *$ \\
\hline Potassium & 19,238 & 1.2961 & no $\quad \mathrm{RQ}$ & 6.2913 \\
\hline Selenium (EP toxic) & 50 & 0.0034 & 45.4 & 0.0164 \\
\hline
\end{tabular}


Table 2-7. Process Condensate Nonradionuclide Source Term. (4 sheets)

\begin{tabular}{|c|c|c|c|c|}
\hline Chemical & $\begin{array}{l}\text { Maximum } \\
\text { concen- } \\
\text { tration } \\
\text { (ppb) }\end{array}$ & $\begin{array}{l}\text { Maximum } \\
C-100 \\
\text { inventory } \\
(\mathrm{kg})\end{array}$ & $\begin{array}{c}\text { CERCLA } \\
\text { Reportable } \\
\text { quant ity } \\
(\mathrm{kg})\end{array}$ & $\begin{array}{l}\text { Maximum } \\
\text { quantity } \\
\text { per day } \\
(\mathrm{kg})\end{array}$ \\
\hline Silicon & 985,819 & 66.4 & no $R Q$ & 322.3865 \\
\hline Silver (EP toxic) & 50 & 0.0034 & 454 & 0.0164 \\
\hline Sodium & 51,497 & 3.4695 & 4.54 & $16.8408 *$ \\
\hline Strontium & 30 & 0.0020 & no $R Q$ & 0.0098 \\
\hline Sulfate & 13,000 & 0.8758 & no $\mathrm{RQ}$ & 4.2513 \\
\hline Sulfide & 66,000 & 4.4466 & no $R Q$ & 21.5836 \\
\hline Uranium & 2.03 & 0.0001 & 45.4 & 0.0007 \\
\hline Vanadium & 7 & 0.0005 & no $R Q$ & 0.0023 \\
\hline Zinc & 44 & 0.0030 & 454 & 0.0144 \\
\hline Acetone & 5,100 & 0.3436 & 2,270 & 1.6678 \\
\hline Benzyl alcohol & 18 & 0.0012 & no $R Q$ & 0.0059 \\
\hline Benzaldehyde & 23 & 0.0015 & no $R Q$ & 0.0075 \\
\hline 2-Butoxyethanol & 920 & 0.0620 & no $R Q$ & 0.3009 \\
\hline $\begin{array}{l}\text { 1-Butanol or } \\
\text { butyl alcohol }\end{array}$ & $1.21 E+5$ & 8.1521 & 2,270 & 39.570 \\
\hline $\begin{array}{l}\text { 2-Butanone or } \\
\text { methylethylketone }\end{array}$ & 120 & 0.0081 & 2,270 & 0.0392 \\
\hline Butoxyglycol & 810 & 0.0546 & no $R Q$ & 0.2649 \\
\hline Butoxydiglycol & 27 & 0.0018 & no $R Q$ & 0.0088 \\
\hline $\begin{array}{l}\text { Butoxytri- } \\
\text { ethyleneglycol }\end{array}$ & 35 & 0.0024 & no $R Q$ & 0.0114 \\
\hline Butraldehyde & 230 & 0.0155 & no $R Q$ & 0.0752 \\
\hline $\begin{array}{l}\text { Chloroform or } \\
1,1,1 \text {-Trichloromethane }\end{array}$ & 27 & 0.0018 & 4.54 & 0.0088 \\
\hline Caproic acid & 70 & 0.0047 & no $R Q$ & 0.0229 \\
\hline 3,5-Dimethylpyridine & 24 & 0.0016 & 2,270 & 0.0078 \\
\hline Dimethylnitrosamine & 57 & 0.0038 & 0.454 & 0.0186 \\
\hline Dodecane & 46 & 0.0031 & no $R Q$ & 0.0150 \\
\hline
\end{tabular}


Table 2-7. Process Condensate Nonradionuclide Source Term. (4 sheets)

\begin{tabular}{|c|c|c|c|c|}
\hline Chemical & $\begin{array}{l}\text { Maximum } \\
\text { concen- } \\
\text { tration } \\
(\mathrm{ppb})\end{array}$ & $\begin{array}{c}\text { Maximum } \\
\text { C-100 } \\
\text { inventory } \\
(\mathrm{kg})\end{array}$ & $\begin{array}{c}\text { CERCLA } \\
\text { Reportable } \\
\text { quant ity } \\
(\mathrm{kg})\end{array}$ & $\begin{array}{l}\text { Maximum } \\
\text { quantity } \\
\text { per day } \\
(\mathrm{kg})\end{array}$ \\
\hline $\begin{array}{l}\text { Ethoxytriethylene } \\
\text { glycol }\end{array}$ & 150 & 0.0101 & no $\mathrm{RQ}$ & 0.0491 \\
\hline $\begin{array}{l}\text { Ethanol or } \\
\text { ethyl al cohol }\end{array}$ & 2 & 0.0001 & 0.454 & 0.0007 \\
\hline Hexanoic acid & 70 & 0.0047 & no $\mathrm{RQ}$ & 0.0229 \\
\hline Hexadecane & 17 & 0.0011 & no $\mathrm{RQ}$ & 0.0056 \\
\hline 2-Hexanone & 79 & 0.0053 & no $\mathrm{RQ}$ & 0.0258 \\
\hline Heptadecane & 18 & 0.0012 & no $R Q$ & 0.0059 \\
\hline Methoxydiglycol & 52 & 0.0035 & no $R Q$ & 0.0170 \\
\hline Methoxytriglycol & 370 & 0.0249 & no $\mathrm{RQ}$ & 0.1210 \\
\hline M-Methoxymethanamine & 120 & 0.0081 & no $\mathrm{RQ}$ & 0.0392 \\
\hline Methlene chloride & 180 & 0.0121 & 454 & 0.0589 \\
\hline Methyl Nitrate & 240 & 0.0162 & no $\mathrm{RQ}$ & 0.0785 \\
\hline Methyl N-propyl ketone & 12 & 0.0008 & no $R Q$ & 0.0039 \\
\hline $\begin{array}{l}\text { Methyl N-butyl ketone } \\
\text { or } 2 \text {-Pentanone }\end{array}$ & 79 & 0.0053 & no $R Q$ & 0.0258 \\
\hline $\begin{array}{l}\text { Methyl i sobutylketone } \\
\text { (MIBK-Hexone) }\end{array}$ & 68 & 0.0046 & 2,270 & 0.0222 \\
\hline 2-Methylnonane & 17 & 0.0011 & no $\mathrm{RQ}$ & 0.0056 \\
\hline Methyl vinyl ketone & 22 & 0.0015 & no $\mathrm{RQ}$ & 0.0072 \\
\hline $\begin{array}{l}\text { N-Nitrosodim- } \\
\text { ethylamine }\end{array}$ & 57 & 0.0038 & 4.54 & 0.0186 \\
\hline Nitromethane & 8 & 0.0005 & no $R Q$ & 0.0026 \\
\hline Pentadecane & 20 & 0.0013 & no $\mathrm{RQ}$ & 0.0065 \\
\hline Phenol & 33 & 0.0022 & 454 & 0.0108 \\
\hline 2-Propenol & 39 & 0.0026 & 0.454 & 0.0128 \\
\hline Pyridine & 550 & 0.0371 & 454 & 0.1799 \\
\hline Tetradecane & 440 & 0.0296 & no $R Q$ & 0.1439 \\
\hline
\end{tabular}


Table 2-7. Process Condensate Nonradionuclide Source Term. (4 sheets)

\begin{tabular}{|l|r|r|r|r|}
\hline \multicolumn{1}{|c|}{ Chemical } & $\begin{array}{r}\text { Maximum } \\
\text { concen- } \\
\text { tration } \\
(\mathrm{ppb})\end{array}$ & $\begin{array}{c}\text { Maximum } \\
\text { C-100 } \\
\text { inventory } \\
(\mathrm{kg})\end{array}$ & $\begin{array}{c}\text { CERCLA } \\
\text { Reportable } \\
\text { quantity } \\
(\mathrm{kg})\end{array}$ & $\begin{array}{c}\text { Maximum } \\
\text { quantity } \\
\text { per day } \\
(\mathrm{kg})\end{array}$ \\
\hline Tetrahydrofuran & 170 & 0.0115 & 454 & 0.0556 \\
\hline Tributyl phosphate & 21,000 & 1.4148 & no RQ & 6.8675 \\
\hline $1,1,1-$ Trichlorethane & 5 & 0.0003 & 454 & 0.0016 \\
\hline Tridecane & 350 & 0.0236 & no RQ & 0.1145 \\
\hline Triglyme & 90 & 0.0061 & no RQ & 0.0294 \\
\hline Undecane & 950 & 0.0640 & no RQ & 0.3107 \\
\hline
\end{tabular}


Table 2-8. Process Condensate Nonradionuclide Source Term Data. ( 3 sheets)

\begin{tabular}{|c|c|c|c|c|c|c|c|}
\hline (1) & (2) & (3) & (4) & (5) & (6) & (7) & (8) \\
\hline Chemical & $\begin{array}{l}\text { LERF } \\
\text { (ppb) }\end{array}$ & $\begin{array}{l}\text { EFSD } \\
\text { (ppb) }\end{array}$ & $\begin{array}{c}\text { CRH } \\
\text { (ppb) }\end{array}$ & $\begin{array}{l}\text { LINK } \\
\text { (ppb) }\end{array}$ & $\begin{array}{l}\text { ASF } \\
(\mathrm{ppb})\end{array}$ & $\begin{array}{l}\text { SALT } \\
(\mathrm{ppb})\end{array}$ & $\begin{array}{l}\text { DWP } \\
(\mathrm{ppb})\end{array}$ \\
\hline Aluminum & 4,992 & 4,992 & 1,470 & 1,650 & 1,770 & 642 & 1,800 \\
\hline Ammonia & & & 1. $E+6$ & $2.5 E+5$ & $2.19 E+6$ & $8.89 E+4$ & \\
\hline Ammonium & $9.35 E+6$ & $9.35 E+6$ & & & & & $2.2 E+6$ \\
\hline $\begin{array}{l}\text { Arsenic } \\
\text { (EP toxic) }\end{array}$ & & & & & 50 & & \\
\hline $\begin{array}{l}\text { Barium } \\
\text { (EP toxic) }\end{array}$ & & & & & 232 & & \\
\hline Barium & 8 & 8 & 6 & 6 & 8 & & 8 \\
\hline Boron & 151 & 151 & & & 13 & & 1.3 \\
\hline Cadmium & & & & 5 & 10 & & 5 \\
\hline Calcium & 8,300 & 7,900 & 7,880 & 4,370 & 8,320 & 447 & 8,300 \\
\hline Carbonate & $7.5 E+5$ & $7.5 E+5$ & & & & & \\
\hline Chloride & 2,300 & 2,300 & 932 & 1,170 & 2,300 & & 2,300 \\
\hline Chromium & 156 & 156 & & & 50 & & \\
\hline Copper & 127 & 127 & & 73 & 12 & & 73 \\
\hline Fluoride (IC) & & & & & & & 2,100 \\
\hline $\begin{array}{l}\text { Fluoride } \\
\text { (IS E) }\end{array}$ & & & & & & & 65 \\
\hline Fluoride & 12,273 & 1,200 & & 35 & 1,070 & & \\
\hline Iron & 503 & 503 & & 156 & 67 & & 160 \\
\hline Lead & & & & & 50 & & \\
\hline Magnes i um & 3,670 & 3,670 & 71 & 4,030 & 748 & & 4,000 \\
\hline Manganese & 5 & 5 & & & 5 & & \\
\hline $\begin{array}{l}\text { Mercury } \\
\text { (EP Toxic) }\end{array}$ & & & & & 10 & & \\
\hline Mercury & 0.69 & 0.7 & 0.69 & 0.48 & 0.56 & 0.23 & 0.69 \\
\hline Nickel & 17 & 17 & & 17 & 14 & 13 & 17 \\
\hline Nitrate & 5,000 & 4,980 & & 4,980 & & & 5,000 \\
\hline Phosphorus & 6,195 & 6,195 & & & & & \\
\hline Potassium & 19,238 & 19,238 & & 1,710 & 15,700 & 5,280 & 16,000 \\
\hline $\begin{array}{l}\text { Selenium } \\
\text { (EP toxic) }\end{array}$ & & & & & 50 & & \\
\hline silicon & 985,819 & 985,819 & & & 9,400 & & 9,400 \\
\hline $\begin{array}{l}\text { Silver } \\
\text { (EP toxic) }\end{array}$ & & & & & 50 & & \\
\hline Sodium & 51,497 & 51,497 & & 25,600 & 33,200 & 2,730 & 33,000 \\
\hline strontiun & & & & & 30 & & \\
\hline
\end{tabular}


Table 2-8. Process Condensate Nonradionuclide Source Term Data. (3 sheets)

\begin{tabular}{|c|c|c|c|c|c|c|c|}
\hline (1) & (2) & (3) & (4) & (5) & (6) & (7) & (8) \\
\hline Chemical & $\begin{array}{l}\text { LERF } \\
\text { (ppb) }\end{array}$ & $\begin{array}{l}\text { EFSD } \\
\text { (ppb) }\end{array}$ & $\begin{array}{l}\text { CRW } \\
\text { (ppb) }\end{array}$ & $\begin{array}{l}\text { LINK } \\
\text { (ppb) }\end{array}$ & $\begin{array}{l}\text { ASF } \\
\text { (ppb) }\end{array}$ & $\begin{array}{l}\text { SALT } \\
(\mathrm{ppb})\end{array}$ & $\begin{array}{l}\text { OWP } \\
(\mathrm{ppb})\end{array}$ \\
\hline Sulfate & 13,000 & & & 13,000 & 3,900 & & 13,000 \\
\hline Sulfide & 66,000 & 65,600 & & 65,600 & & & \\
\hline Uranium & & & 1.35 & 0.475 & 2.03 & & \\
\hline Vanadium & 7 & 7 & & 5 & 7 & & \\
\hline 2 inc & & & 5 & 34 & 17 & 44 & 44 \\
\hline Acetone & 5,100 & 5,100 & 2,570 & 5,100 & 2,160 & 1,200 & 5,100 \\
\hline Benzyl alcohol & 18 & 18 & 18 & 10 & 17 & 11 & 18 \\
\hline $\begin{array}{l}\text { Benzalde- } \\
\text { hyde }\end{array}$ & 23 & 23 & & 23 & & & \\
\hline $\begin{array}{l}\text { 2-Butoxy- } \\
\text { ethanol }\end{array}$ & 920 & 920 & 840 & 920 & 490 & 98 & 92 \\
\hline $\begin{array}{l}\text { 1-Butanol or } \\
\text { butyl alcohol }\end{array}$ & 88,000 & 88,000 & 88,000 & 1,130 & $1.21 E+5$ & 525 & 88,000 \\
\hline $\begin{array}{l}\text { 2-Butanone or } \\
\text { methylethyl } \\
\text { ketone }\end{array}$ & 120 & 120 & 90 & 120 & 93 & 44 & 120 \\
\hline Butoxyglycol & 810 & 810 & 540 & 135 & 360 & 806 & 810 \\
\hline Butoxydiglycol & 27 & 27 & & 11 & 27 & & \\
\hline $\begin{array}{l}\text { Butoxytri- } \\
\text { ethyl-eneglycol }\end{array}$ & 35 & 35 & & & 35 & & \\
\hline Butraldehyde & 230 & 230 & & & & & \\
\hline $\begin{array}{l}\text { Chloroform or } \\
1,1,1-\text { tri- } \\
\text { chloromethane }\end{array}$ & 27 & 27 & & & & & \\
\hline Caproic acid & 70 & 70 & & & & & \\
\hline $\begin{array}{l}3,5-0 \mathrm{i}- \\
\text { methyl-pyridine }\end{array}$ & 24 & 24 & 24 & & & & \\
\hline $\begin{array}{l}\text { Dimethyl- } \\
\text { ni trosamine }\end{array}$ & 57 & 57 & & & & & \\
\hline Dodecane & 46 & 46 & & 46 & & & \\
\hline $\begin{array}{l}\text { Ethoxytri- } \\
\text { ethylene } \\
\text { glycol }\end{array}$ & 150 & 150 & & 150 & & 120 & \\
\hline $\begin{array}{l}\text { Ethanol or } \\
\text { ethyl alcohol }\end{array}$ & 2 & 2 & & & 2 & & \\
\hline Hexanoic acid & & & & 70 & & & \\
\hline Hexadecane & 17 & 17 & & 17 & & & \\
\hline 2-Hexanone & & & 11 & 20 & 79 & 10 & \\
\hline Heptadecane & 18 & 18 & & 18 & & & \\
\hline
\end{tabular}


Table 2-8. Process Condensate Nonradionuclide Source Term Data. ( 3 sheets)

\begin{tabular}{|c|c|c|c|c|c|c|c|}
\hline (1) & (2) & (3) & (4) & (5) & (6) & (7) & (8) \\
\hline Chemical & $\begin{array}{l}\text { LERF } \\
\text { (ppb) }\end{array}$ & $\begin{array}{l}\text { EFSD } \\
\text { (ppb) }\end{array}$ & $\begin{array}{l}\text { CRW } \\
\text { (ppb) }\end{array}$ & $\begin{array}{l}\operatorname{LINK} \\
\text { (ppb) }\end{array}$ & $\begin{array}{l}\text { ASF } \\
\text { (ppb) }\end{array}$ & $\begin{array}{l}\text { SALT } \\
(p p b)\end{array}$ & $\begin{array}{l}\text { DWP } \\
(\mathrm{ppb})\end{array}$ \\
\hline $\begin{array}{l}\text { Methoxy- } \\
\text { diglycol }\end{array}$ & 52 & 52 & & 28 & & 52 & \\
\hline $\begin{array}{l}\text { Methoxytri- } \\
\text { glycol }\end{array}$ & 370 & 370 & & 370 & & 65 & \\
\hline $\begin{array}{l}\text { M-Methoxyme- } \\
\text { thanamine }\end{array}$ & & 120 & & & & & \\
\hline $\begin{array}{l}\text { Methylene } \\
\text { chloride }\end{array}$ & 180 & 180 & & & & & \\
\hline Methyl nitrate & & 240 & & & & & \\
\hline $\begin{array}{l}\text { Methyl } \\
\text { N-propyl } \\
\text { ketone }\end{array}$ & 12 & 12 & & & & & 12 \\
\hline $\begin{array}{l}\text { Methyl } N \text {-butyl } \\
\text { ketone or } \\
\text { 2-pentanone }\end{array}$ & 79 & 79 & 12 & 11 & & & 79 \\
\hline $\begin{array}{l}\text { Methyl isobutyl } \\
\text { ketone (MIBK- } \\
\text { hexone) }\end{array}$ & 68 & 68 & 5 & 68 & & 8 & 68 \\
\hline $\begin{array}{l}2 \cdot \text { Methyl- } \\
\text { nonane }\end{array}$ & 17 & 17 & & & 17 & & \\
\hline $\begin{array}{l}\text { Methyl vinyl } \\
\text { ketone }\end{array}$ & & 22 & & & & & \\
\hline $\begin{array}{l}\mathrm{N} \text {-Ni trosodi- } \\
\text { methylamine }\end{array}$ & & & & 57 & & & \\
\hline Nitromethane & & 8 & & & & & \\
\hline Pentadecane & 20 & 20 & & 20 & & & \\
\hline Phenol & 33 & 33 & & 33 & & & \\
\hline 2-Propenol & 39 & 39 & 39 & 22 & 24 & 34 & 39 \\
\hline Pylidine & 550 & 550 & & 550 & & & \\
\hline Tetradecane & 440 & 440 & 26 & 440 & 25 & 320 & 440 \\
\hline Tetrahydro-furan & 170 & 170 & 18 & 30 & 81 & 170 & 170 \\
\hline $\begin{array}{l}\text { Tributyl } \\
\text { phosphate }\end{array}$ & 21,000 & 21,000 & 6,800 & 20,600 & 10,100 & 6,150 & 21,000 \\
\hline $\begin{array}{l}\text { 1,1,1-Tri- } \\
\text { chlorethane }\end{array}$ & 5 & 5 & & & & & \\
\hline Tridecane & 350 & 350 & 18 & 350 & 28 & 300 & 350 \\
\hline Triglyme & 90 & 90 & & 90 & & & \\
\hline Undecane & & 950 & & & & & \\
\hline
\end{tabular}


Therefore, one gram/1iter is equal to $1,000,000 \mathrm{ppb}$. This conversion was used to calculate the values tabulated in the third and the fifth columns.

The "Maximum C-100 inventory" column is the total possible quantity of the constituent present in the Process Condensate Collection Tank $(\mathrm{C}-100)$ calculated on the tanks maximum capacity of $17,800 \mathrm{gal}$ or $67,373 \mathrm{~L}$.

The "CERCLA" column is the RQ that, if released in a 24-h period, is reportable under CERCLA.

An asterisk $\left({ }^{*}\right)$ denotes the existence of the possibility that a constituent might be CERCLA reportable if released.

At a process condensate generation rate of $227 \mathrm{~L} / \mathrm{min}(60 \mathrm{gal} / \mathrm{min})$, it is possible to generate $327,024 \mathrm{~L} / \mathrm{d}(86,400 \mathrm{gal})$. The "Maximum quantity per day" column has been included to identify any constituents that could become reportable under CERCLA if the process condensate were to be released to the environment during an entire $24-h$ period.

Table 2-8 presents the data that were used to develop Table 2-7. Table 2-8 lists nonradionuclide constituents in the process condensate. The data in each of the columns have been compiled from the following references.

Column (1) LERF: Reference--Internal Memo 86132-91-MOA-006; Dated January 22, 1991; From Effluent Technology; Subject: Re-submittal of Data for Inclusion in the W-105 Functional Design Criteria (Table A-1, Liquid Effluent Retention Facility Effluent Characterization Data) (WHC 1991f).

Column (2) EFSD: Reference--WHC-SD-C018-001, Rev 1, Table C-1, Effluent Characterization Data (WHC 1990e).

Column (3) CRW: Cladding Removal Waste (CRW) Feed: reference-WHC-EP-0342, Addendum 15, 242-A Evaporator Process Condensate Stream-Specific Report (WHC 1990C).

Column (4) LINK: Linked Run Feed: reference--WHC-EP-0342, Addendum 15, 242-A Evaporator Process Condensate Stream-Specific Report.

Column (5) ASF: Ammonia Scrubber Feed: reference--WHC-EP-0342, Addendum 15, 242-A Evaporator Process Condensate StreamSpecific Report.

Column (6) SALT: Saltwell Feed: reference--WHC-EP-0342, Addendum 15, 242-A Evaporator Process Condensate Stream-Specific Report.

Column (7) DWP: Reference--D0E/RL-90-42, 242-A Evaporator Dangerous Waste Permit Application (DOE-RL 1990). 
The recommended safety source term of ammonium in the evaporator process condensate is 3.0 × 10 $0^{+07} \mathrm{ppb}$ [reference--Internal Memo 86132-91-M0A-006 (Table A-3, LERF Effluent Characterization Data), dated January 22, 1991 ; From: Effluent Technology; Subject: RE-SUBMITTAL OF DATA FOR INCLUSION IN THE W-105 FUNCTIONAL DESIGN CRITERIA] and is the proposed LERF inventory control operational safety requirement maximum allowable concentration (Technical Basis Document, WHC-SD-WM-TI-448) (WHC 1990). This value is not used because the available data do not show ammonium to exist at this concentration.

\subsubsection{Process Condensate Radiological Potential Source Terms}

Table 2-9 lists alpha and beta radionuclide constituents in the process condensate. The data in each of the columns have been compiled from the following references:

Column (1) CRW: Cladding Removal Waste (CRW) Feed: reference-WHC-EP-0342, Addendum 15, 242-A Evaporator Process Condensate Stream-Specific Report (WHC 1990C)

Column (2) LINK: Linked Run Feed: reference--WHC-EP-0342, Addendum 15, 242-A Evaporator Process Condensate Stream-Specific Report

Column (3) ASF: Ammonia Scrubber Feed: reference--WHC-EP-0342, Addendum 15, 242-A Evaporator Process Condensate Stream-Specific Report

Column (4) SALT: Saltwell Feed: reference--WHC-EP-0342, Addendum 15, 242-A Evaporator Process Condensate Stream-Specific Report.

Table 2-9. Process Condensate Radionuclide Data.

\begin{tabular}{|l|c|c|c|c|c|}
\hline Effluent & $\begin{array}{c}(1) \\
(\mathrm{CRW} \\
(\mu \mathrm{Ci} / \mathrm{mL})\end{array}$ & $\begin{array}{c}(2) \\
(\mu \mathrm{INK}\end{array}$ & $\begin{array}{c}(3) \\
\text { ASF } \\
(\mu \mathrm{Ci} / \mathrm{mL})\end{array}$ & $\begin{array}{c}(4) \\
\text { SALTWELL } \\
(\mu \mathrm{Ci} / \mathrm{mL})\end{array}$ & $\begin{array}{c}\text { Maximum } \\
(\mu \mathrm{Ci} / \mathrm{mL})\end{array}$ \\
\hline Alpha & $2.78 \mathrm{E}-10$ & $1.62 \mathrm{E}-09$ & $1.01 \mathrm{E}-09$ & & $1.62 \mathrm{E}-9$ \\
\hline Beta & $1.09 \mathrm{E}-06$ & $4.34 \mathrm{E}-06$ & $1.25 \mathrm{E}-05$ & $1.61 \mathrm{E}-06$ & $1.25 \mathrm{E}-5$ \\
\hline
\end{tabular}

Table 2-10 contains data on process condensate radionuclide constituents from the following sources:

For 1987/1988/1989 values: reference--WHC-EP-0141-0/-1/-2, Westinghouse Hanford Company Effluent Discharges and Solid Waste Management Report for 1987/1988/1989: 200/600 Areas (WHC 1988d, 1989f, 1990a)

For 1984/1985/1986 values: reference--WHC-SD-WM-SAR-023, 242-A Evaporator Safety Analysis Report (WHC 1988a). 
Table 2-10. Process Condensate Radionuclide Data.

\begin{tabular}{|c|c|c|c|c|c|c|c|}
\hline \multirow{2}{*}{ Effluent } & \multicolumn{6}{|c|}{ Ye:r } & \multirow{2}{*}{ Maximum } \\
\hline & 1384 & 1985 & 1986 & 1987 & 1988 & 1989 & \\
\hline \multirow{3}{*}{$\begin{array}{l}\text { Total } \\
\text { volume } \\
(L)\end{array}$} & $5.3 E+7$ & $4.9 E+7$ & $5.0 \mathrm{E}+7$ & $2.45 E+7$ & $4.92 E+7$ & $1.34 \mathrm{E}+7$ & $5.3 E+7$ \\
\hline & \multirow[t]{2}{*}{$(\mu \mathrm{C} i / \mathrm{mL})$} & \multirow[t]{2}{*}{$(\mu[\mathrm{i} / \mathrm{mL})$} & \multirow[t]{2}{*}{$(\mu \subset \mathrm{i} / \mathrm{mL})$} & $(\mu \mathrm{Ci} / \mathrm{mL})$ & $(\mu \mathrm{Ci} / \mathrm{mL})$ & $(\mu \mathrm{Ci} / \mathrm{mL})$ & \multirow{2}{*}{$(\mu \mathrm{C} / \mathrm{mL})$} \\
\hline & & & & (ci) & (ci) & (ci) & \\
\hline \multirow[t]{2}{*}{ Alpha } & \multirow[t]{2}{*}{$1.3 \mathrm{E}-8$} & \multirow[t]{2}{*}{$1.7 \mathrm{E}-8$} & \multirow[t]{2}{*}{$2.4 E-8$} & $2 \mathrm{E}-8$ & $2 E-8$ & $1.1 \mathrm{E}-8$ & \multirow[t]{2}{*}{$2.4 E-8$} \\
\hline & & & & $6 E-4$ & $7 \mathrm{E}-4$ & $1.4 \mathrm{E}-4$ & \\
\hline \multirow[t]{2}{*}{ Beta } & \multirow[t]{2}{*}{$4.1 \mathrm{E}-7$} & \multirow[t]{2}{*}{$2.1 \mathrm{E}-6$} & \multirow[t]{2}{*}{$5.0 \mathrm{E}-6$} & $2 E-6$ & $4 \mathrm{E}-6$ & $2.0 \mathrm{E}-6$ & \multirow[t]{2}{*}{$5.0 \mathrm{E}-6$} \\
\hline & & & & $4 \mathrm{E}-2$ & $2 E-2$ & $2.7 \mathrm{E}-2$ & \\
\hline \multirow[t]{2}{*}{${ }^{3} \mathrm{H}$} & \multirow[t]{2}{*}{$2.4 \mathrm{E}-2$} & \multirow[t]{2}{*}{$1.1 \mathrm{E}-2$} & \multirow[t]{2}{*}{$1.1 \mathrm{E}-2$} & $6 \mathrm{E}-3$ & $6 \mathrm{E}-3$ & $8.7 E-3$ & \multirow[t]{2}{*}{$2.4 E-2$} \\
\hline & & & & $1.5 E+2$ & $1.3 E+2$ & $1.2 E+2$ & \\
\hline \multirow[t]{2}{*}{${ }^{241} \mathrm{Am}$} & & & & & \multirow[t]{2}{*}{ c } & $2.8 E-8$ & \multirow[t]{2}{*}{$2.8 E-8$} \\
\hline & & & & & & $3.7 \mathrm{E}-4$ & \\
\hline \multirow[t]{2}{*}{${ }^{137} \mathrm{Cs}$} & \multirow[t]{2}{*}{$1.6 \mathrm{E}-7$} & \multirow[t]{2}{*}{$A .6 \mathrm{E}-7$} & \multirow[t]{2}{*}{$5.6 \mathrm{E}-7$} & $2 E-7$ & $3 \mathrm{E}-7$ & $8.0 \mathrm{E}-8$ & \multirow[t]{2}{*}{$5.6 \mathrm{E}-7$} \\
\hline & & & & $5 E-3$ & $2 E-2$ & $1.1 \mathrm{E}-3$ & \\
\hline${ }^{147} \mathrm{Pm}$ & $4.4 \mathrm{E}-7$ & $1.8 \mathrm{E}-6$ & $1.1 \mathrm{E}-6$ & & & & $1.8 \mathrm{E}-6$ \\
\hline${ }^{129} \mathrm{I}$ & & & $1.9 \mathrm{E}-8$ & $6 E-8$ & $3 E-8$ & $2.4 E-8$ & $6 E-8$ \\
\hline & & & & $1 E-3$ & $2 E-3$ & $3.2 E-4$ & \\
\hline Uranium & $8.5 \mathrm{E}-8$ & $3.1 \mathrm{E}-8$ & $1.2 \mathrm{E}-9$ & & c & c & $8.5 E-8$ \\
\hline $239,240 \mathrm{Pu}$ & & & & & c & $1.5 \mathrm{E}-8$ & $1.5 \mathrm{E}-8$ \\
\hline & & & & & & $2.0 \mathrm{E}-4$ & \\
\hline${ }^{106} \mathrm{Ru}$ & & & & & $2 E-6$ & $4.5 \mathrm{E}-7$ & $2 E-6$ \\
\hline & & & & & $9 \mathrm{E}-2$ & $6.0 \mathrm{E}-3$ & \\
\hline${ }^{147} \mathrm{Pm}$ & & & & & c & & \\
\hline${ }^{103} \mathrm{Ru}$ & & & & & c & & \\
\hline${ }^{113} \mathrm{Sn}$ & & & & $6 \mathrm{E}-7$ & $3 \mathrm{E}-7$ & & $6 E-7$ \\
\hline & & & & $2 \mathrm{E}-2$ & $2 E-2$ & & \\
\hline${ }^{90} \mathrm{Sr}$ & $8.7 \mathrm{E}-8$ & $3.4 \mathrm{E}-7$ & $3.8 E-7$ & $2 \mathrm{E}-7$ & $3 E-8$ & $1.6 \mathrm{E}-8$ & $3.8 \mathrm{E}-7$ \\
\hline & & & & $6 \mathrm{E}-3$ & $2 E-3$ & $2.2 \mathrm{E}-4$ & \\
\hline
\end{tabular}

$c=$ analysis was not necessary las determined from inventory, effluent history, and/or gross alpha/beta analyses). 
Table 2-11 contains data concerning process condensate radionuclide constituents. The data in each of the columns have been compiled from the following references.

Column (1) Reference--Internal Memo 86132-91-M0A-006 (Table A-1, LERF Effluent Characterization Data), dated January 22, 1991; From: Effluent Technology; Subject: RE-SUBMITTAL OF DATA FOR INCLUSION IN THE W-105 FUNCTIONAL DESIGN CRITERIA (WHC 1991f).

Column (2) Reference--Internal Memo 86132-91-MOA-006 (Table A-2, LERF Effluent Characterization Data), dated January 22, 1991; From: Effluent Technolozy; Subject: RE-SUBMITTAL OF DATA FOR INCLUSION IN THE W-105 FUNCTIONAL DESIGN CRITERIA (WHC 1991f). Proposed LERF inventory control operational safety requirement maximum allowable concentration (Technical Basis Document, WHC-SD-WM-TI-448) (WHC 1990i).

Column (3) Reference--WHC-SD-C018-001, Rev 1 (Table C-1, Effluent Characterization Data) (WHC 1990e).

Table 2-12 compares the maximum process condensate radionuclide constituents from each row of Tables 2-9, 2-10, and 2-11:

Table 2-13 contains the process condensate radionuclide constituent source term values derived from Table 2-12 and compares these values to the maximum possible inventory (curies) in a full process conderisate collection tank $(C-100)$ which has a maximum capacity of $67,373 \mathrm{~L}(17,800$ gal $)$. Also included is the total quantity (in curies) possible within a 24-h time frame, calculated on a $227-\mathrm{L} / \mathrm{min}(60-\mathrm{gal} / \mathrm{min}) \mathrm{rate}$ of process condensate generation. This process rate produces $327,024 \mathrm{~L} / \mathrm{d}(86,400 \mathrm{gal} / \mathrm{d})$. 
Table 2-11. Process Condensate Radionuclide Data.

\begin{tabular}{|l|c|c|c|c|}
\hline Radionuclide & $\begin{array}{c}\left(\begin{array}{c}(1) \\
(\mu \mathrm{Ci} / \mathrm{mL})\end{array}\right. \\
(\mu \mathrm{Ci} / \mathrm{mL})\end{array}$ & $\begin{array}{c}(3) \\
(\mu \mathrm{Ci} / \mathrm{mL})\end{array}$ & $\begin{array}{c}\text { Maximum } \\
(\mu \mathrm{Ci} / \mathrm{mL})\end{array}$ \\
\hline Alpha & $7.5 \mathrm{E}-07$ & & $9.5 \mathrm{E}-07$ & $9.5 \mathrm{E}-7$ \\
\hline Beta & $7.4 \mathrm{E}-05$ & & $7.4 \mathrm{E}-05$ & $7.4 \mathrm{E}-5$ \\
\hline${ }^{90} \mathrm{Sr}$ & $8.100 \mathrm{E}-06$ & $4.91 \mathrm{E}-04$ & $8.1 \mathrm{E}-05$ & $4.91 \mathrm{E}-4$ \\
\hline${ }^{106} \mathrm{Ru}$ & $1.78 \mathrm{E}-05$ & $9.92 \mathrm{E}-03$ & $1.78 \mathrm{E}-05$ & $9.92 \mathrm{E}-3$ \\
\hline${ }^{137} \mathrm{Cs}$ & $2.6 \mathrm{E}-06$ & $4.16 \mathrm{E}-04$ & $2.6 \mathrm{E}-05$ & $4.16 \mathrm{E}-4$ \\
\hline${ }^{147} \mathrm{Pm}$ & $4.1 \mathrm{E}-06$ & $1.23 \mathrm{E}-03$ & $4.1 \mathrm{E}-06$ & $1.23 \mathrm{E}-3$ \\
\hline $\begin{array}{l}\text { Uranium } \\
\text { (gross) }\end{array}$ & $1.40 \mathrm{E}-07$ & $1.89 \mathrm{E}-05$ & $1.4 \mathrm{E}-07$ & $1.89 \mathrm{E}-05$ \\
\hline${ }^{3} \mathrm{H}$ & $2.4 \mathrm{E}-02$ & $5.29 \mathrm{E}+00$ & $2.4 \mathrm{E}-02$ & $5.29 \mathrm{E}+00$ \\
\hline${ }^{239} \mathrm{Pu}$ & $2.4 \mathrm{E}-12$ & $3.49 \mathrm{E}-10$ & $2.4 \mathrm{E}-12$ & $3.49 \mathrm{E}-10$ \\
\hline${ }^{113} \mathrm{Sn}$ & $2.50 \mathrm{E}-06$ & $5.10 \mathrm{E}-04$ & $2.5 \mathrm{E}-06$ & $5.10 \mathrm{E}-04$ \\
\hline${ }^{155} \mathrm{Eu}$ & $1.4 \mathrm{E}-06$ & $1.32 \mathrm{E}-03$ & $1.4 \mathrm{E}-07$ & $1.32 \mathrm{E}-03$ \\
\hline
\end{tabular}


Table 2-12. Process Condensate Radionuclide Data.

\begin{tabular}{|c|c|c|c|c|}
\hline \multirow{2}{*}{ Effluent } & \multicolumn{3}{|c|}{ Maximum $(\mu \mathrm{C} i / \mathrm{mL})$} & \multirow{2}{*}{$\begin{array}{c}\text { Maximum } \\
\text { (comparison) } \\
(\mu \mathrm{C} i / \mathrm{mL})\end{array}$} \\
\hline & Table 2-10 & Table 2-11 & Table 2-12 & \\
\hline Alpha & $2.4 E-08$ & $1.62 \mathrm{E}-9$ & $9.5 \mathrm{E}-7$ & $9.5 \mathrm{E}-7$ \\
\hline Beta & $5.0 \mathrm{E}-06$ & $1.25 E-5$ & $7.4 \mathrm{E}-5$ & $7.4 \mathrm{E}-5$ \\
\hline${ }_{3} \mathrm{H}$ & $2.4 E-02$ & & $5.29 E+00$ & 5.29 \\
\hline${ }^{241} \mathrm{Am}$ & $2.8 E-08$ & & & $2.8 E-8$ \\
\hline${ }^{137} \mathrm{Cs}$ & $5.6 E-07$ & & $4.16 E-4$ & $4.16 E-4$ \\
\hline${ }^{147} \mathrm{Pm}$ & $1.8 E-06$ & & $1.23 \mathrm{E}-3$ & $1.23 \mathrm{E}-3$ \\
\hline${ }^{129} \mathrm{I}$ & $6 E-08$ & & & $6 \mathrm{E}-8$ \\
\hline Uranium & $8.5 E-08$ & & $1.89 E-05$ & $1.89 E-5$ \\
\hline $239,240 \mathrm{Pu}$ & $1.5 E-08$ & & $3.49 E-10$ & $1.5 \mathrm{E}-8$ \\
\hline${ }^{106} \mathrm{Ru}$ & $2 E-06$ & & $9.92 E-3$ & $9.92 E-3$ \\
\hline${ }^{113} \mathrm{Sn}$ & $6 \mathrm{E}-07$ & & $5.10 \mathrm{E}-04$ & $5.1 E-4$ \\
\hline${ }^{89,90} \mathrm{sr}$ & $3.8 \mathrm{E}-07$ & & $4.91 E-4$ & $4.91 E-4$ \\
\hline${ }^{155} \mathrm{Eu}$ & & & $1.32 E-03$ & $1.32 \mathrm{E}-3$ \\
\hline
\end{tabular}


WHC-EP-0466-1

Table 2-13. Process Condensate Radionuclide Source Term.

\begin{tabular}{|l|r|r|r|}
\hline \multirow{2}{*}{ Effluent } & \multicolumn{3}{|c|}{ Maximum } \\
\cline { 2 - 4 } & \multicolumn{1}{|c|}{$(\mu \mathrm{Ci} / \mathrm{mL})$} & $\begin{array}{c}\text { C-100 } \\
(\mathrm{Ci})\end{array}$ & \multicolumn{1}{c|}{$\begin{array}{l}24 \mathrm{H} \\
(\mathrm{Ci})\end{array}$} \\
\hline Alpha & $9.5 \mathrm{E}-7$ & 0.0001 & 0.0003 \\
\hline Beta & $7.4 \mathrm{E}-5$ & 0.0050 & 0.024 \\
\hline${ }^{3 \mathrm{H}}$ & 5.29 & 356.4 & $1,729.96$ \\
\hline${ }^{241} \mathrm{Am}$ & $2.8 \mathrm{E}-8$ & $1.89 \mathrm{E}-6$ & $9.16 \mathrm{E}-6$ \\
\hline${ }^{137} \mathrm{Cs}$ & $4.16 \mathrm{E}-4$ & 0.028 & 0.14 \\
\hline${ }^{147} \mathrm{Pm}$ & $1.23 \mathrm{E}-3$ & 0.083 & 0.402 \\
\hline${ }^{129} \mathrm{I}$ & $6 \mathrm{E}-8$ & $4.04 \mathrm{E}-6$ & $1.96 \mathrm{E}-5$ \\
\hline Uranium & $1.89 \mathrm{E}-5$ & 0.0013 & 0.0062 \\
\hline${ }^{239,240} \mathrm{Pu}$ & $1.5 \mathrm{E}-8$ & $1.01 \mathrm{E}-6$ & $4.91 \mathrm{E}-6$ \\
\hline${ }^{106} \mathrm{Ru}$ & $9.92 \mathrm{E}-3$ & 0.67 & 3.24 \\
\hline${ }^{113} \mathrm{Sn}$ & $5.1 \mathrm{E}-4$ & 0.034 & 0.167 \\
\hline${ }^{89,90} \mathrm{Sr}$ & $4.91 \mathrm{E}-4$ & 0.033 & 0.161 \\
\hline${ }^{155} \mathrm{Eu}$ & $1.32 \mathrm{E}-3$ & 0.089 & 0.432 \\
\hline
\end{tabular}




\subsection{APPLICABLE REGULATIONS}

The purpose of this section is to present information on the regulations governing effluent monitoring requirements for radioactive, nonradioactive hazardous, and mixed waste materials in effluents. It also focuses on applicable environmental standards and statutes, including Westinghouse Hanford effluent monitoring requirements.

\subsection{REGULATIONS}

Several regulatory agencies including the U.S. Environmental Protection Agency (EPA), DOE, Washington State, and the Benton-Franklin-Walla Walla Counties Air Pollution Control Authority have developed regulations pertaining to effluent releases at the Hanford Site. A summary of applicable regulations and standards is presented in Table 3-1. Because the regulations enforced by these agencies sometimes are different and Westinghouse Hanford may enforce more restrictive requirements as a matter of policy, Westinghouse Hanford has documented the policies for compliance in the environmental compliance manual, WHC-CM-7-5 (WHC 1992i). This document is the controlling reference for Westinghouse Hanford environmental protection criteria.

\subsubsection{Protection of the Public and the Environment}

To ensure the public's health and safety, DOE-controlled facilities are required to monitor effluents that have the potential of containing regulated materials. Regulations pertaining to the monitoring and environmental surveillance of effluents typically are based on effluent release limits for specific materials that are associated with their risks to the public. Monitoring requirements and associated limitations also may be based on best available technology (for liquid control technology, best available airborne control technology for airborne control technology), best practical control technology currently available, or other technology-based criteria. In addition, some monitoring requirements and associated limitations are based on environmental protection criteria, such as water-quality-based discharge standards. The effluent release iimits for nonradioactive and radioactive materials are designed to ensure that the risk to the public and the environment posed by these facilities is reduced to an acceptable level.

As documented in 40 CFR Part 61, "National Emission Standards for Hazardous Air Pollutants," (EPA 1991b) effluent release limits for benzene and radioactive materials are based on limiting risk to the public by limiting the potential dose to the maximally exposed member of the public. Similarly, for most nonradioactive materials, the risk to the public and the environment is controlled by limiting the quantities of materials released.

In the case of nonradioactive effluents, monitoring requirements also may exist to protect the worker. To provide a safe workplace environment, monitoring of nonradioactive effluents is based on the level or quantity of material present at the point of generation within the facility. Currently, an accurate method does not exist for projecting from the inventory at risk to the estimated release source term at the discharge point. 
WHC-EP-0466-1

Table 3-1. Applicable Regulations and Standards.

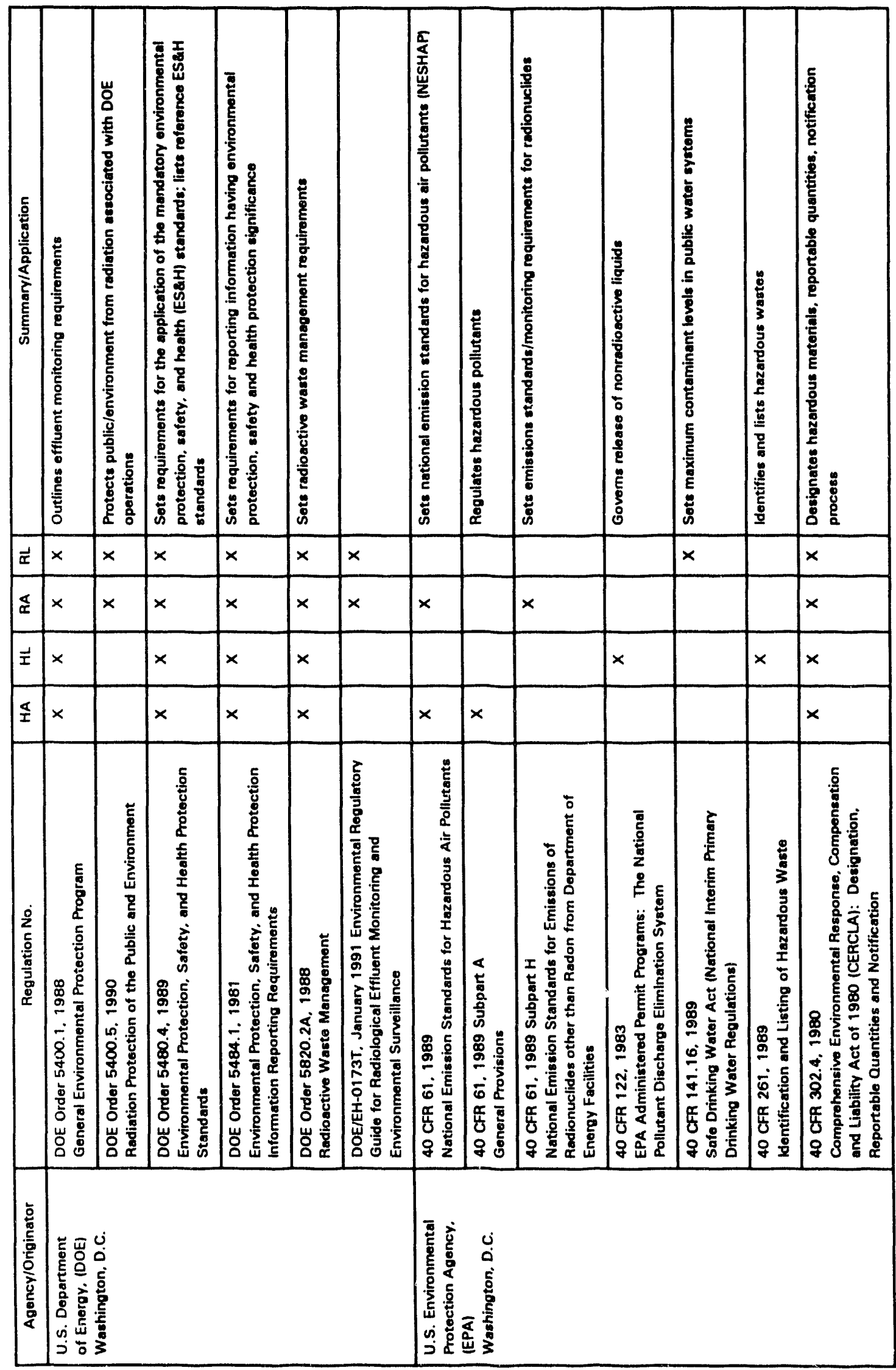


WHC-EP-0466-1

Table 3-1. Applicable Regulations and Standards.

\begin{tabular}{|c|c|c|c|c|c|c|c|c|c|c|c|c|c|}
\hline 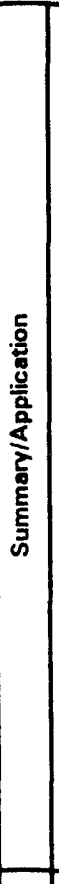 & 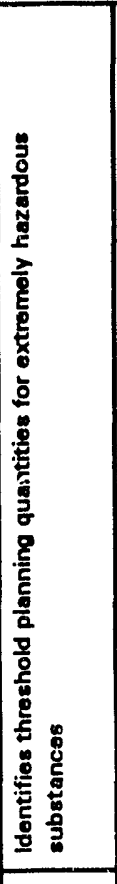 & 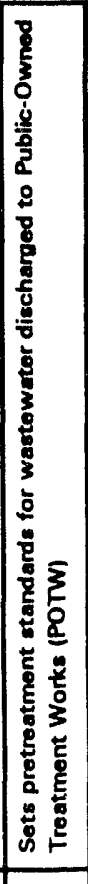 & 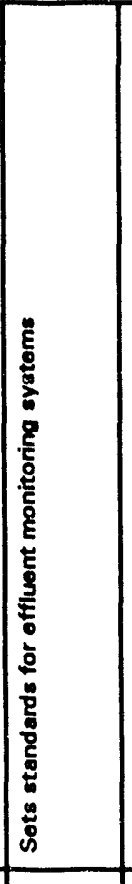 & 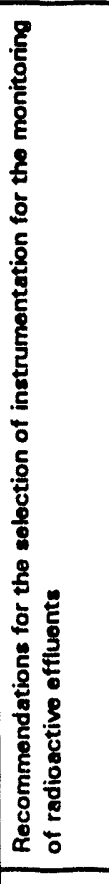 & 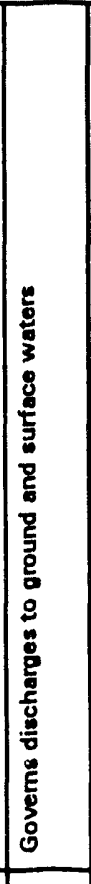 & 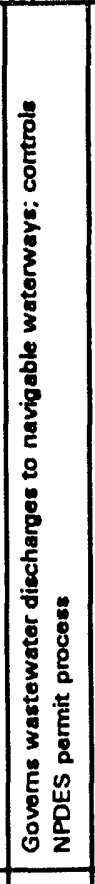 & 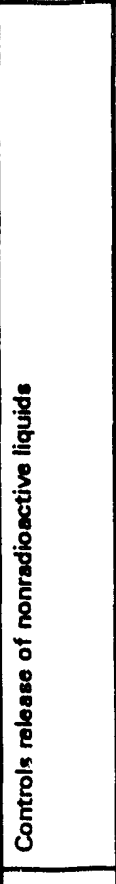 & 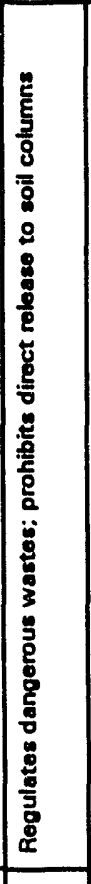 & 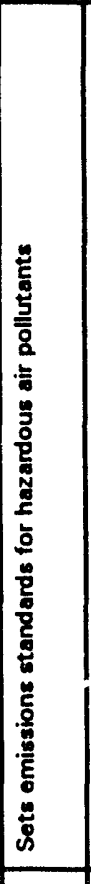 & 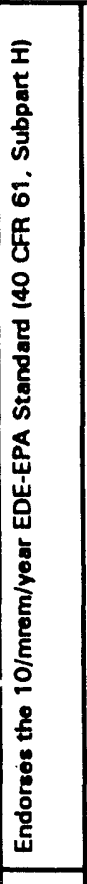 & 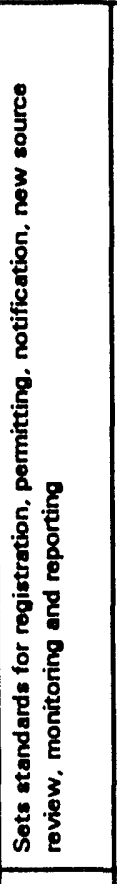 & 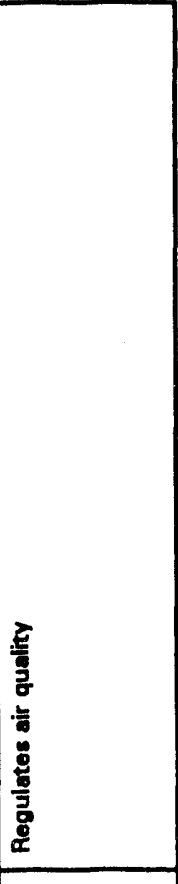 & \\
\hline$\vec{\alpha}$ & & & & $x$ & & $x$ & & & & & & & \\
\hline 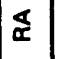 & & & $x$ & $x$ & & & & & $x$ & $x$ & $x$ & & \\
\hline$\vec{I}$ & $x$ & $x$ & & & $x$ & $x$ & $x$ & $x$ & & & & & \\
\hline$\underline{I}$ & $x$ & & & & & & & & $x$ & $x$ & $x$ & $x$ & \\
\hline 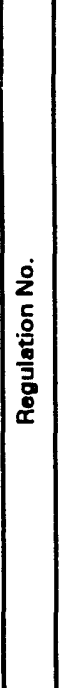 & 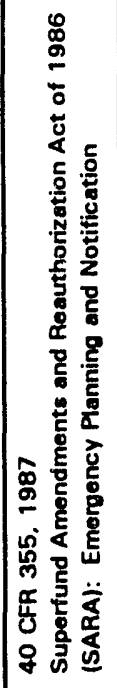 & 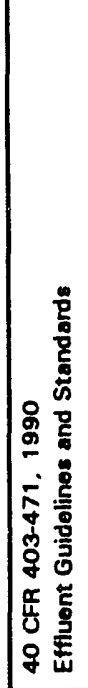 & 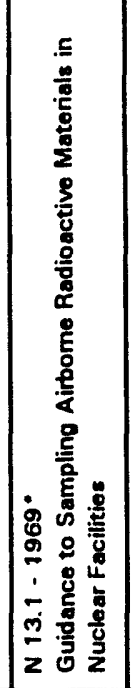 & 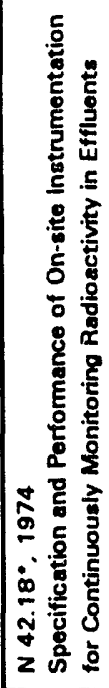 & 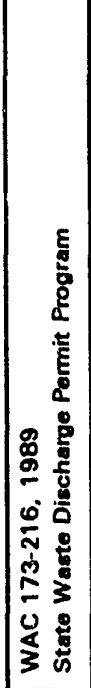 & 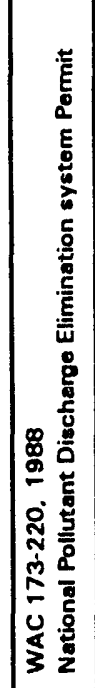 & 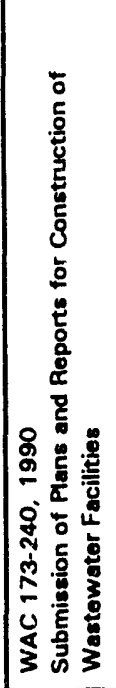 & 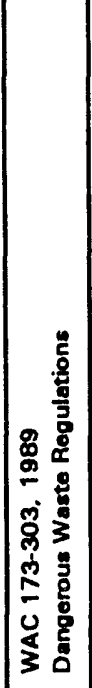 & 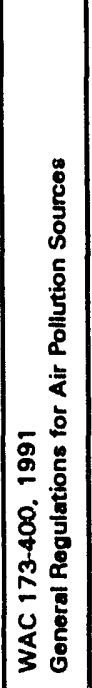 & 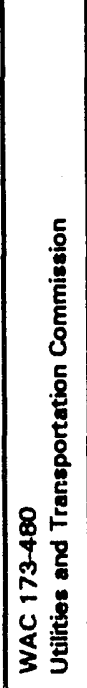 & 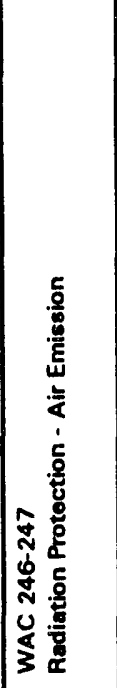 & 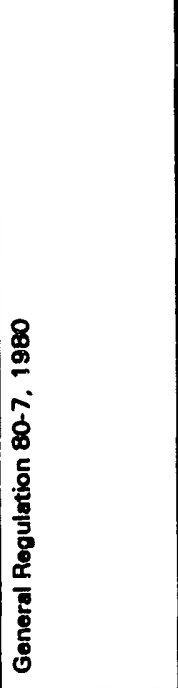 & 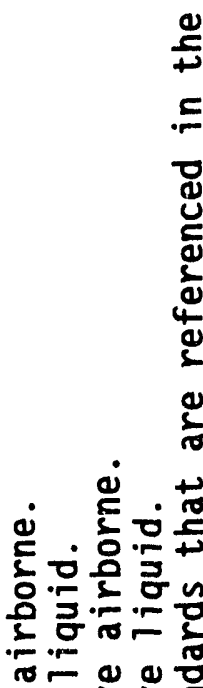 \\
\hline 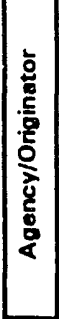 & 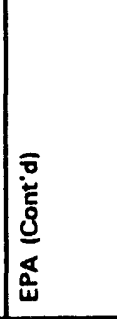 & & 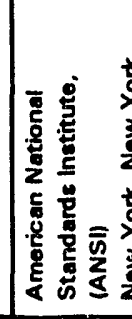 & & 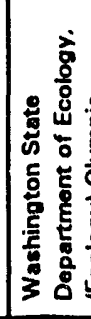 & 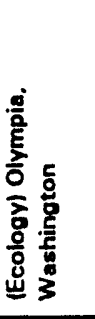 & & & & & 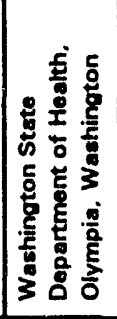 & 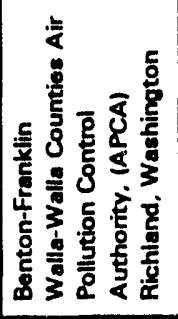 & 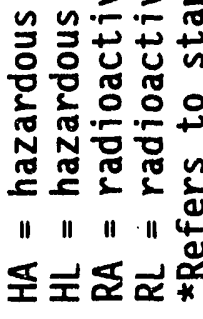 \\
\hline
\end{tabular}


The EPA NESHAPs require that radionuclide emissions from each DOE site shall not cause any individual (maximally exposed individual) to receive a dose of greater than $10 \mathrm{mrem} / \mathrm{yr}$ EDE. A single site or facility, as used here, means all the buildings, structures, and operations within one contiguous site. For example, the entire DOE facility at the Hanford Site, rather than each building, must meet the $10 \mathrm{mrem} / \mathrm{yr}$ EDE standard. In DOE Order 5400.5, paragraph II.1.b (DOE 1990b), the dose from airborne radioactivity is 1 imited to 10 mrem EDE, which is consistent with the EPA standards.

DOE Order 5400.5, "Radiation Protection of the Public and the Environment" (DOE 1990b), provides dose limits from all DOE sources of radiation and all exposure modes of $100 \mathrm{mrem} / \mathrm{yr}$ EDE and $5 \mathrm{rem} / \mathrm{yr}$ dose equivalent limit for any tissue (including the skin and lens of the eye) to the public from operations at DOE facilities. These limits apply to doses originating from exposures to radiation sources during routine activities, as well as to exposures from remedial actions in progress on the same site. Although the current 1 imit is $100 \mathrm{mrem} / \mathrm{yr}$, it is recommended that a FEMP be prepared as if the NESHAPs will be instituted with the $10 \mathrm{mrem} / \mathrm{yr}$ EDE 1 imit. Effluent monitoring and the associated plan would be required at a level of $1 \%$ of the $10 \mathrm{mrem} / \mathrm{yr}$ EDE standards; that is, at $0.1 \mathrm{mrem} / \mathrm{yr}$ EDE.

The limit of $100 \mathrm{mrem} / \mathrm{yr}$ EDE is the sum of the EDE (or deep dose equivalent, if dosimeter data are used) from exposures during the year to radiation sources external to the body plus the committed EDE from radionuclides taken into the body. The calculation of doses from routine DOE activities should be based on a "reference man," as defined by the International Commission on Radiation Protection (ICRP) and the dosimetry models and parameters presented in ICRP Publication 30 (ICRP 1979) and subsequent publications. The weighing factors and time periods for integrating doses endorsed by the ICRP are to be used for dose commitment calculations. Other requirements are presented, including how doses from other synthetic or enhanced natural radionuclide sources must be addressed.

The DOE Order 5400.5, Chapter II, Paragraph 1.b. (DOE 1990b) limits exposure of the public to radioactive materials from all DOE sources of radiation. The order states that DOE activities shall not cause any member of the public to receive, in a year, a dose equivalent greater than $100 \mathrm{mrem}$ to the whole body. The order also stipulates that DOE must comply with legally applicable requirements, including 40 CFR 61 (NESHAP) (EPA 1991b) for airborne emissions. Doses attributed to ${ }^{220} \mathrm{Rn},{ }^{222} \mathrm{Rn}$, and their respective decay products are specifically excluded from the NESHAP dose standard. However, they are regulated by DOE Order 5400.5 .

To demonstrate compliance with the dose limit requirements using analytical techniques, evaluations of potential doses to individuals through the air pathway shall be evaluated using only AIRDOSE/RADRISK (Beres 1990) or other computer codes or models specifically approved by EPA, as specified in NESHAP. Compliance also may be demonstrated through environmental measurements taken using approved techniques. When using this method to determine compliance, estimated doses are for individuals who are assumed to reside in an unrestricted area at the point of maximum annual air concentration. 
WHC-EP-0466-1

\subsection{REgULATIONS PERTAINING TO MONITORING REQUIREMENTS AT U.S. DEPARTMENT OF ENERGY FACILITIES}

The monitoring requirements for effluents resulting from the operation of DOE-controlled sites can be presented in two categories related to the effluent release pathway: airborne or liquid. In addition, information on monitoring requirements is presented whether the effluent is radioactive or nonradioactive material. Before presenting this material, however, it is useful to review in detail the requirements outlined by DOE for FEMPS.

\subsubsection{U.S. Department of Energy Facility Effluent Monitoring Plan}

Requirements for a FEMP are provided in DOE Order 5400.1, "General Environmental Protection Program" (DOE 1990a). The order provides specific information in Chapter IV on the requirements for effluent monitoring systems and programs at the Hanford Site. Environmental monitoring requirements are different for new and existing facilities.

For a new facility with the potential for adverse impact on the environment, an environmental survey must be conducted before actual startup. This survey shall establish background levels of radioactive and toxic pollutants, characterize pertinent environmental and ecological parameters, and identify potential pathways for human exposure or environmental impact as a basis for determining the nature and extent of the subsequent routine operational effluent and environmental monitoring program.

For existing facilities, radioactive and nonradioactive pollutant effluents released at the Hanford Site shall be monitored to determine compliance. Their monitoring is performed to evaluate the effectiveness of effluent treatment and control, inventory radioactive material, and determine compliance with all DOE, EPA, state, and local requirements pertaining to effluents and pollutant impact on the environment. Radioactive material released to onsite waste treatment or disposal systems shall be monitored to assess the effectiveness of treatment and control and to provide both a qualitative and quantitative annual summary of the radioactive material released onsite.

DOE Order 5400.1 (DOE 1990a) also provides guidance on effluent monitoring. As a general rule, monitoring should be conducted in a manner that provides accurate measurements of the quantity and/or concentration of liquid and airborne pollutants in effluents as a basis for:

- Determining compliance with applicable discharge and effluent control limits, including self-imposed administrative limits designed to ensure compliance with in-plant operating limits, effluent standards, or guides; and with environmental standards and guides

- Evaluating the adequacy and effectiveness of containment and waste treatment and control, as well as of efforts toward achieving levels of radioactivity that are as low as reasonably achievable (ALARA) considering technical and economical constraints 
- Compiling an annual inventory of the radioactive material released in effluents and onsite discharges.

Because the requirements in DOE Order 5400.1 (DOE 1990a) are relatively general, interpretation of the requirements is necessary to determine the effluent monitoring practices required to meet the intent of the order and associated regulations. In the case of airborne releases, 40 CFR 61 (EPA 1991b), ANSI N13.1-1969 (ANSI 1969), and associated documents provide specific requirements and guidelines for effluent monitoring and sampling. the case of liquid releases, however, currently accepted guidance does not provide consolidated, detailed requirements. Therefore, required practices are based on industry-accepted standards and good practices that are sufficient to meet the intent of the regulations, including the primary requirement that all effluent samples obtained be representative of the effluent released. The following discussion summarizes the primary monitoring and sampling practices that are necessary to comply with DOE Order 5400.1 (DOE 1990a) and associated regulations.

Effluent monitoring data collected as close as possible to the point of discharge should include volume, rate of discharge, and content. Effluent monitoring data pertaining to the release of nonradioactive pollutant material should include the total quantity (amount). Effluent monitoring data pertaining to the release of radioactive material is to include the total activity (number of curies) released in airborne and liquid effluents and the specific radionuclides comprising a significant portion ( $>10 \%)$ of the radiation dose. Although exceptions exist, this requirement indicates that the measurement should be made at the point of discharge. When a portion of the effluent stream is close to the point of generation, measurement then could provide a more accurate estimate of the hazardous material being released from the facility, and an exception may be allowed.

Effluents should be monitored at the point at which the applicable standards apply. For example, onsite discharges may be monitored at the waste treatment and disposal system. Effluents may be monitored at the point after all treatment and control, including retention and decay, has occurred. In many cases, the monitoring location is specified in the discharge or operating permit.

The sampling method and frequency should be determined by considering the purpose or need for the data collected. Data are collected to

- Evaluate the effectiveness of waste treatment and control

- Demonstrate compliance with operating limits of applicable effluent or performance standards

- Compile and trend effluent characteristics.

Continuous or proportional sampling is recommended and may be required where the concentrations and mixtures of potential pollutants in the effluent stream vary significantly. Periodic sampling may be adequate when the concentrations and mixtures are reasonably constant and the likelihood of unusual variations is minimal. Similarly, proportional sampling may be 
necessary when effluent flow rates fluctuate, whereas a representative grabsample may suffice for batch discharges. The method of sampling usually is specified in the applicable regulation or permit.

In reporting radiological data, gross radioactivity measurements are generally inadequate. However, they can be appropriate when

- Gross radioactivity releases are a small fraction of the offsite Radioactivity Concentration Guides (RCG) for "unidentified mixtures" and have no health or environmental significance

- The relative concentrations of specific radionuclides are so well known by other means that gross radioactivity measurements are truly indicative of the activity being released

- The activity of waste streams is so low as to preclude specific radionuclide measurements.

For radioactive effluents, onsite discharge monitoring and reporting must be adequate to provide an annual average concentration and an annual summary of the quantities of radioactive materials released. The summary should include all significant or reportable releases. It is required, therefore, that the annual average flow and pollutant concentration be determined for each waste stream.

The EPA regulations pertaining to the release of hazardous substances from DOE facilities are presented in 40 CFR 302, "Designation, Reportable Quantities, and Notification" (EPA 1991C). This regulation, in accordance with Sections 101(14) and 102(a) of CERCLA, designates those substances in the statites of CERCLA, identifies reportable quantities of those substances, and sets forth the notification requirements for releases of these substances. This regulation also sets forth reportable quantities for hazardous substances designated under Section 311(b)(2)(A) of the Clean Water Act of 1977.

\subsubsection{Airborne Effluents}

Airborne emissions of radioactive materials from DOE-controlled facilities at the Hanford Site are subject to EPA regulations. The primary regulation is 40 CFR Part 61 (NESHAP) (EPA 1991b). The list of hazardous air pollutants regulated under the NESHAP is provided in Subpart A, "General Provisions." The specific emissions standards and monitoring requirements for radionuclides are contained in Subpart $H$, "National Emission Standards for Emissions of Radionuclides Other Than Radon From Department of Energy Facilities, " of the proposed 40 CFR Part 61 . Subpart $H$ standards cover all DOE operations that emit radionuclides other than radon to the air, except for facilities subject to 40 CFR Part 191, Subpart B (disposal of spent nuclear fuel, high-level, and transuranic radioactive wastes) (EPA 1991d) and 40 CFR Part 192 (uranium and thorium mill tailings) (EPA 199le).

Subpart $H$ of the NESHAP presents detailed requirements for emissions monitoring and test procedures (61.93), compliance and reporting (61.94), record-keeping requirements (61.95), and exemptions from the reporting and testing requirements of 40 CFR Part 61.10 (61.97) (EPA 1991b). Radionuclide 
emission rates from stacks and vents must be measured at all release points that have the potential to release radionuclides into the air in quantities that could cause an EDE in excess of $1 \%$ of the standard. The potential to release radionuclides must be based on the emissions from the effluent stream that would result if all pollution control equipment did not exist, but facility operation(s) was otherwise normal [40 CFR part 61.93 (b)(4)(ii)]. For release points that have a potential to release radionuclides into the air, but have effluents below the continuous monitoring standard, periodic confirmatory measurements must be made to verify low emissions. Also, all radionuclides that could contribute greater than $10 \%$ of the potential EDE for each release point must be measured. With prior EPA approval, alternative methods to the one described, including process knowledge, can be substituted for measurement to determine the emission levels of individual radionuclides.

Subpart $H$, Section 61.93, specifies the monitoring requirements for determining radionuclide emission rates. These requirements include sampling points, appropriate sampling methods, flow rate determinations, sampling frequency, analytical methods, and quality assurance procedures. Direct measurement of air concentrations of radionuclides at the receptor point is acceptable if the criteria in Section 61.93(b)(5) are met. These criteria include continuous monitoring of released radionuclides, satisfactory detection limits, quality assurance, and prior EPA approval.

The NESHAPs require that plants monitor their operations continuously and keep records of the results of their onsite monitoring for $5 \mathrm{yr}$. Westinghouse Hanford would have to certify semiannually that there have been no changes in operations that would require new testing. Although the report is based on the calendar year, the emission limit applies to any period of 12 consecutive months.

Additional EPA requirements on hazardous substances are contained in 40 CFR Part 302.4 (EPA 1991C). This regulation provides information on reportable quantities of nonradioactive hazardous substances. Unlisted hazardous substances designated by 40 CFR Part 302.4 are regulated in accordance with the EPA toxicity of the contaminant.

Several DOE orders provide requirements for monitoring of radioactive and nonradioactive emissions from DOE facilities at Hanford. These orders state that DOE-controlled facilities must comply with 40 CFR Part 61 (NESHAP) (EPA 1991b). The principal orders are DOE Order 5400.5, "Radiation Protection of the Pubiic and the Environment" (DOE 1990b), and DOE Order 5400.1, Chapter IV, "Environmental Monitoring Requirements" (DOE 1990a).

In Washington State, airborne emissions are regulated by the Clean Air Act of 1977. General regulations for air-pollution sources are presented in WAC 173-400 (Ecology 1990c), including emission standards for sources emitting hazardous air pollutants in WAC 173-400-075 (Ecology 1990c).

The WAC 246-247, Radiation Protection Air Emissions (Ecology 1990f), specifies new source review, notification, registration, and permitting requirements associated with any source of radioactive airborne emissions in Washington State, including those on the Hanford Site. One requirement 
listed in WAC 246-247 is the semiannual (twice yearly) reporting of emissions from each registered stack or vent onsite. By agreement with the Washington State Department of Health, only annual reporting is required.

The WAC 173-480, Ambient Radionuclides (Ecology 1990g), defines maximum allowable levels for radionuclides in the ambient air and defines required levels of control of emissions. The regulation was last revised May 7, 1986, and is enforced by Ecology.

While both the WAC 246-247 and 173-480 list outdated maximum EDE standards, each contains a caveat stating that any more stringent federal standards take precedence over the EDE standard specified by the WAC. Therefore, each effectively endorses the $10 \mathrm{mrem} / \mathrm{yr}$ EDE standard of the 40 CFR 61 , subpart $H$.

The U.S. Department of Energy, Richland Field Office, (RL) contractor policies for radioactive airborne releases are discussed in WHC-CM-7-5 (WHC 1992i). This environmental compliance manual refers to the applicable regulations governing the monitoring of radioactive emissions in NESHAP (EPA 1991b). Other regulations, including DOE orders, state that DOE facilities must comply with the requirements set forth in the NESHAP. Other regulations include: 40 CFR Part 52, "Approval and Promulgation of Implementation PIans" (EPA 1991f); and DOE Orders 5400.1 (DOE 1990a), 5400.5 (DOE 1990b), and 5484.1 (DOE 1981).

\subsubsection{Liquid Effluents}

Requirements limiting the exposure of the public to radioactive materials from DOE-controlled activities through the drinking water pathway are presented in DOE Order 5400.5, Chapter II, paragraph 1.d (DOE 1990b). Although the radiological criteria of the public community drinking water standards of 40 CFR Part 141 (EPA 1991g) are not applicable to DOE-operated drinking water systems, it is DOE's policy to provide an equivalent level of protection for a11 persons consuming the water from a drinking water supply operated by, or for, DOE. These systems shall not cause any person consuming the water to receive an EDE greater than $4 \mathrm{mrem} / \mathrm{yr}$, excluding naturally occurring radionuclides. In addition, DOE facility operators shall ensure that the liquid effluents from DOE activities shall not cause private or public drinking water systems downstream of the facility discharge to exceed the drinking water radiological limits of 40 CFR Part 141.

The dose limit is consistent with the drinking water criteria in 40 CFR 141, "National Interim Primary Drinking Water Regulations" (Safe Drinking Water Act) (EPA 1991g). The dose limit is the EDE to an individual whose exclusive source of drinking water contains a radionuclide, or a mixture of radionuclides, at a level of $4 \%$ of the appropriate derived concentration guide (DCG) value. The maximum contaminant levels in public water systems are found in 40 CFR 141.15 (generally radium and alpha emitters) and in 40 CFR 141.16 (beta and gamma emitters) (EPA 1991g).

Liquid effluents from DOE-controlled facilities that have the potential for radioactive contamination must be monitored in accordance with the 
requirements of DOE Orders 5400.1 (DOE 1990a) and 5400.5 (DOE 1990b). Facility operators must provide monitoring of liquid waste streams adequate to:

- Demonstrate compliance with the applicable requirements of DOE 5400.5, Chapter II

- Quantify radionuclide released from each discharge point

- Alert affected process supervisors of upsets in processes and emissions controls.

Depending on where a liquid effluent (waste water) is discharged, certain regulations apply. These regulations are implemented through issuance of permits by federal, state, and/or local agencies. It is the responsibility of the facility, through RL, to apply for the permit appropriate to the effluent being discharged. Before applying for any permits, the applicant must know the sources of its waste water discharges and where the waste water is being discharged. The following regulatioiss apply based on where the waste water is discharged:

- Waste water discharged to a Publicly-Owned Treatment Works (POTW) is subject to federal regulations found in 40 CFR Parts 403 to 471 (EPA 1991h) and may also be subject to local regulations and limitations. Permits for such discharges are obtained from the local sewerage agency into which the effluent is discharged, or in some cases, from the state. DOE Order 5400.5, paragraph II.3.d (DOE 1990b), sanitary sewage also :ddresses discharges to sewage systems.

- Waste water discharged into a navigable waterway is subject to Washington State regulations (Ecology 1990d) under the National Pollution Discharge Elimination System (NPDES). The EPA issues NPDES permits for such discharges.

- Washington State controls discharges to ground and surface waters of the state, under Chaptor 173-216 WAC (Ecology 1990e). The state issues permits for such discharges. A permit of this type *nuld be necessary for any discharges to land that could infiltrate to groundwater.

Each type of discharge permit identified above typically will contain discharge limitations and monitoring requirements. However, the limitations and monitoring requirements will vary depending on the source and type of waste water being discharged. For those processes that have been categorized by EPA, discharges to a POTW will be subject to pretreatment standards that are based on the production process that generates the waste water.

Categorical processes are identified in 40 CFR Parts 403-471 (EPA 1991h). Specific limitations and monitoring and reporting requirements have been issued for each categorical process. In addition to EPA's requirements, the State and local sewerage agency may impose additionai limitations and monitoring and reporting requirements. Discharges to a navigable waterway also will be subject to certain standards based on the industrial process that generated the waste water; certain additional limitations also are imposed in 
the NPDES permit. In all cases, the specific pollutants to be monitored and the frequency of monitoring and reporting will be based on the applicable regulations and the language of the permit.

The $\mathrm{RL}$, contractor policies for nonradioactive and radioactive liquid effluents are discussed in WHC-CM-7-5 (WHC 1992i). This environmental compliance manual describes current contractor requirements for monitoring and restricting liquid effluents. Applicable requirements are discussed in Section 3.4 of this document.

\subsubsection{Hazardous Mixed Wastes}

Currently no regulations pertain to "mixed waste" in effluents. Radioactive and dangerous/extremely hazardous contaminants in effluent streams are handled as individual components in effluent regulations and in effluent monitoring.

Westinghouse Hanford policies on mixed waste are presented in Section 7 of WHC-CM-7-5 (WHC 1992i).

\subsection{STANDARDS/REFERENCES}

DOE Order 5480.4, Environmental Protection, Safety, and Health Protection Standards (DOE 1984), presents a listing of mandatory statutory policies on environmental standards.

\subsection{WESTINGHOUSE HANFORD COMPANY EFFLUENT MONITORING REQUIREMENTS}

Westinghouse Hanford policy for monitoring effluents is presented in the Environmental Compliance Manual, WHC-CM-7-5 (WHC 1992i). The Westinghouse Hanford manual contains some requirements that are more restrictive than those found in the regulations.

The purpose of the Environmental Compliance Manual is to establish guideTines to be used by Westinghouse Hanford that:

- Protect the environment from radioactive materials and other dangerous substances under Westinghouse Hanford jurisdiction

- Protect people from radionuclides and other dangerous substances in the environment

- Provide a tool to be used in conjunction with applicable DOE orders and other pertinent federal, state, and local laws, rules, and regulations issued for environmental protection in accordance with the policy defined in WHC-CM-1-1, Management Policies, MP 5.1, "Environmental Assurance" (WHC 1992j). 


\subsection{FACILITY REQUIRENENTS FOR ORGANIC EMISSION STANDARDS}

Facilities that operate under a Subtitle C Permit (40 CFR Part 261.3) (EPA 1991i) are required to meet specific organic emission standards as part of an EPA regulatory requirement. These would include hazardous waste treatment, storage, and disposal (TSD) facilities. Included in the final rule are organic emissions form recycling units that do not require a Resource Conservation and Recovery Act of 1976 (RCRA) permit, but are part of a TSD facility that is required to have a Subtitle $C$ Permit. If a hazardous waste management facility that manages wastes has an annual average total organic concentration of $10 \mathrm{ppmw}$ or greater, the facility is required to reduce the total organic emissions from all processes to below $3 \mathrm{lb} / \mathrm{h}$ or 3.1 tons/yr, or install and operate a control device that reduces the total organic emissions by $95 \%$. Facilities that are in compliance are not required to install control devices or to monitor their emissions if it can be shown that organic emissions will never exceed the established limits. The effective date of the final rulemaking was December 21, 1990. 


\subsection{IDENTIFICATION AND CHARACTERIZATION OF EFFLUENT STREAMS}

This chapter identifies and characterizes the effluent streams for the 242-A Evaporator facility.

\subsection{FACILITY EFFLUENT STREAMS}

This section provides a brief description of the effluent streams existing at the 242-A Evaporator facility. Refer to the block diagram of Figure 4-1.

\subsubsection{Gaseous Streams}

The two major airborne effluent release points for the 242-A Evaporator facility are the 296-A-22 stack (vessel ventilation system) and the 296-A-21 stack ("hot area" building ventilation system). A third separate air system supplies the noncontaminated (cold) area and exhausts through miscellaneous dampers and vents.

4.1.1.1 Vessel Ventilation. Noncondensed vapors from the vacuum condenser and process condensate systems are filtered and discharged to the atmosphere via the vessel vent system (refer to Figures 4-1 and 4-2). The aftercondenser and the condensate collection tank (TK-C-100) are vented to the atmosphere through this system. An air intake filter ( $F-C-7$ ) is used to bleed building air into the vessel vent system to maintain proper ventilation balance and prevent deadheading of the vessel vent exhauster.

An air sampling pump (P-AS-1) draws air through various room radiation samplers. The air sampling pump discharges into the vessel ventilation stack just below the fourth floor in the condenser room. The air sampling pump draws air from samplers in the following rooms:

- AMU room

- Change room

- Control room

- Condenser room

- Evaporator room

- Pump room

- Loadout and hot equipment storage room

- Loading room

- Ion exchange column room.

Currently, these room radiation samplers are undergoing an upgrade, which will be completed before startup. 
Figure 4-1. The 242-A Evaporator Block Diagram.

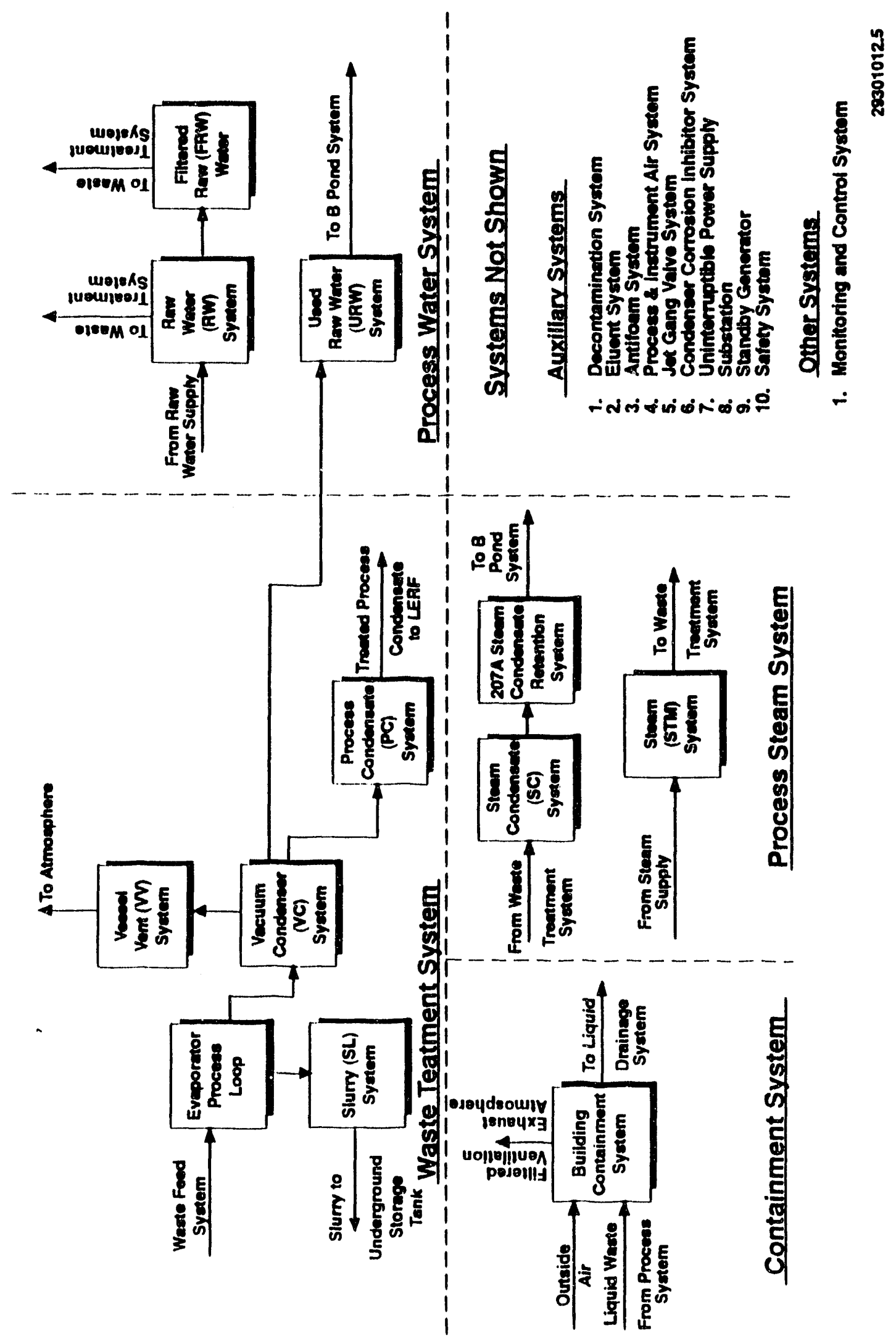


WHC-EP-0466-1

Figure 4-2. The 242-A Evaporator Vessel Vent System.

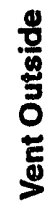

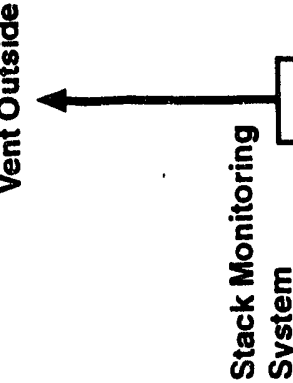

$\frac{0}{\frac{2}{8}}$

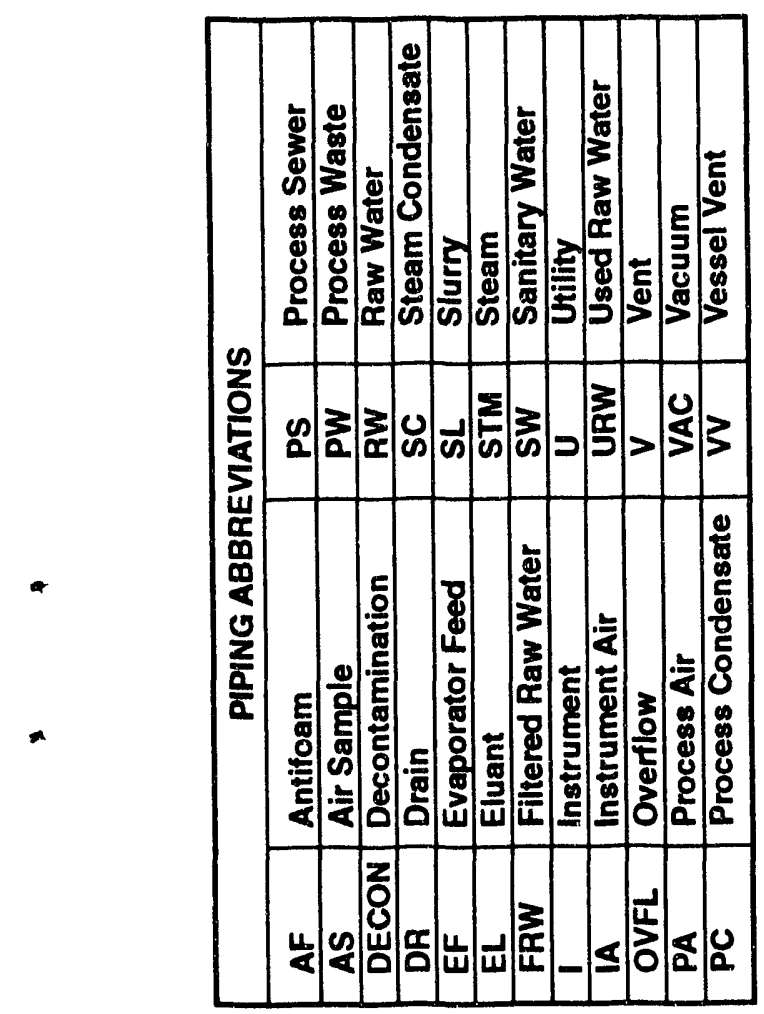

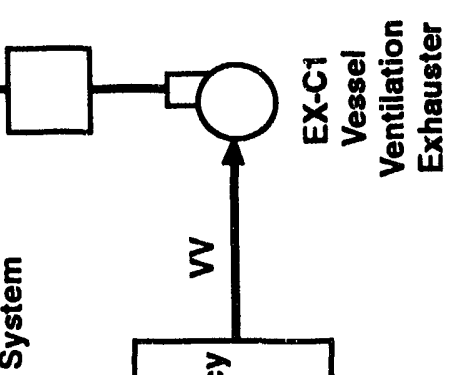
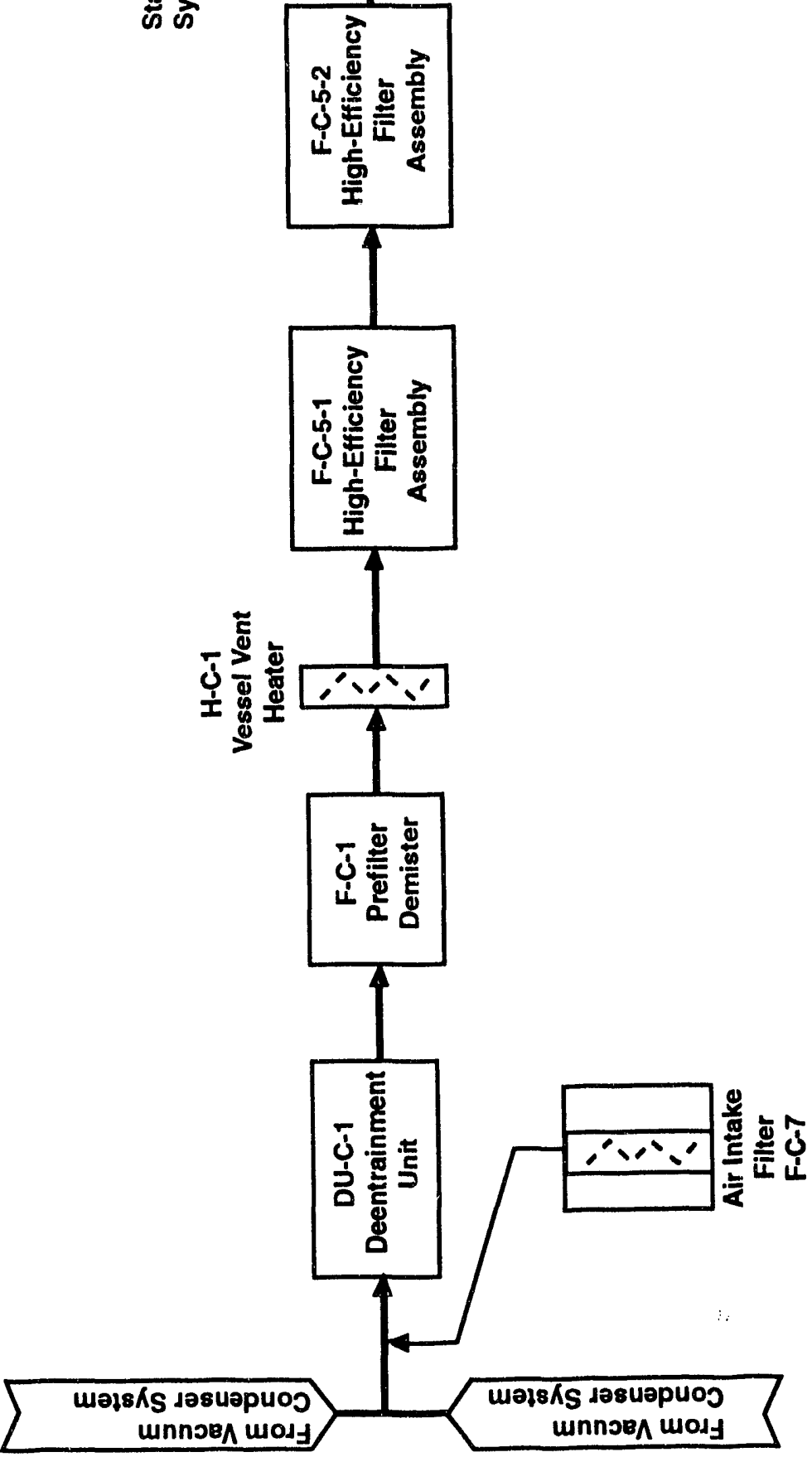
4.1.1.2 Building Ventilation. The 242-A Building ventilation system is divided into four ventilation zones, each of which is supplied by a separate air system. These zones are as follows:

- The office

- The cold (noncontaminated) area, which has a low potential for the release of airborne contaminants

- The hot (contaminated) area, which has a greater potential of releasing airborne contaminants

- The control room.

The airborne effluent stream discharged to the atmosphere via the 296-A-21 stack results from ventilation of the contaminated zones of the 242-A Building. The building ventilation system for the 242-A Evaporator is designed for air to flow from noncontaminated to progressively more contaminated areas. This barrier is accomplished by holding the contaminated areas at a negative pressure and the noncontaminated areas at a positive pressure.

The hot area ventilation system (the building ventilation) serves the following rooms:

- Condenser room

- Pump room

- Evaporator room

- Ion exchange room

- Loading room

- Loadout and hot equipment storage room.

The hot area is supplied with approximately $524 \mathrm{~m}^{3} / \mathrm{min}\left(18,500 \mathrm{ft}^{3} / \mathrm{min}\right)$ of outsjide air from an intake fan (K1-5-1) and approximately $23 \mathrm{~m}^{3} / \mathrm{min}$ (800 $\left.\mathrm{ft}^{3} / \mathrm{min}\right)$ of air inleakage from the loading room. Air from the intake fan passes through a preheat coil $(K 1-2-1)$, dust filters $(K 1-7-1$ and $K 1-11-1)$, air washer $(K 1-3-1)$, and reheat coils (K1-4-1 through $K 1-1-7)$.

The hot area is maintained at a negative pressure so that air enters the potentially contaminated areas rather than exits to the progressively cleaner areas of the building. In addition, individual room air pressures are maintained so that the pressure in highly contaminated rooms is less than in rooms with less potential for contamination.

The noncontaminated zones of the facility are supplied by the cold area ventilation system. This system serves the HVAC room, AMU room, change rooms, corridors, survey room, lunch room, rest rooms, clean- and soiled-clothes storage areas, and supply and storage room. The cold area is pressurized by an intake fan (K2-5-1) that supplies approximately $368 \mathrm{~m}^{3} / \mathrm{min} \quad\left(13,000 \mathrm{ft}^{3} / \mathrm{min}\right)$ of outside air and $23 \mathrm{~m}^{3} / \mathrm{min}\left(800 \mathrm{ft}^{3} / \mathrm{min}\right)$ of recycled air to the area. Intake air is drawn through a preheat coil (K2-2-1), two filters (K2-1-1 and K2-7-1), a reheat coil (K2-4-1), and an air washer (K2-3-1) before entering the area. The HVAC room receives approximately $65 \%$ of the intake air, while the remaining air is circulated throughout the other 
noncontaminated area rooms. Of the outside air intake, approximately $62 \%$ is exhausted from the AMU room exhaust fan (K2-5-2) and approximately $32 \%$ is exhausted from the cold area roof exhauster $(K 2-5-3)$. The remaining air exits to the 242-AB Building or to the atmosphere via leakages.

The exhaust fans for the cold area are controlled by pressure switches associated with the pressure in the AMU room, the corridor, and the survey room (PS-1-2, PS-1-4, and PS-1-1, respective1y). The pressure switches start the exhaust fans when the supply air has reached the preset positive pressure needed to ensure that contaminated air from the hot areas cannot enter the cold area. Operation of the intake fan (K2-5-1) maintains a positive pressure in the cold area. Pressure is maintained by automatic adjustment of the vortex damper on the supply fan controlled by a signal based on static pressure measurements. The air supply to the cold area is limited by a signal from the flow measuring element in the intake fan discharge duct. This signal overrides the signal from the static pressure instrument if the air supply exceeds a preset limit.

The control room and office are separately supplied with fresh air and maintained at a slightly positive pressure by a vent duct from the 242-A facility air supply system. Temperature control in the 242-AB control room is provided using two computer-room air conditioning units.

Radiation areas at the 242-A Evaporator are defined depending on contamination, airborne radioactivity, and source dose rates. Controlled areas act as buffer zones between the nonradiation areas and the radiation source. The controlled areas provide space for stepoff pads, special work permit (SWP) laundry hampers, and survey instrumentation. The health physics technician (HPT) field office is centrally located within Building 242-A.

Personnel entering the noncontaminated areas of the building from the contaminated zones are required to be surveyed to prevent the spread of radioactive contamination to these areas. Portable radiation detection instruments are used to detect and measure alpha, beta, gamma, and neutron radiation, as deemed necessary. The DOE's Pacific Northwest Laboratory (PNL), operated by Battelle Memorial Institute, operates an instrument pool to provide instruments that are exchanged and recalibrated on a regular basis. Table 4-1 lists the instruments available from the central pool. Portal monitors and hand and foot counters are stationary instruments by which personnel can check their clothing, hands, and feet for contamination. These instruments are never used as a substitute for personal surveys, but function as a last checkpoint for radiation workers and office and administrative personnel.

Because the cold area and control room of the facility have little potential to become contaminated and because their respective exhausts are interlocked to close should this situation occur, the noncontaminated area exhausts are not addressed further in this FEMP.

\subsubsection{Liquid Effluent Streams}

Two primary liquid effluent streams associated with the 242-A Evaporator facility are discharged to the environment and are addressed in this FEMP. These are the cooling water, or used raw water (URW), stream and the steam 
Table 4-1. Portable Radiation Detection and Measurement Instruments.

\begin{tabular}{|l|c|c|c|}
\hline \multicolumn{1}{|c|}{ Type of detector } & $\begin{array}{c}\text { Radiation } \\
\text { type } \\
\text { detected }\end{array}$ & \multicolumn{1}{|c|}{$\begin{array}{c}\text { Instrument } \\
\text { range }\end{array}$} & Accuracy \\
\hline Air ion chamber & $B, \gamma$ & $0-5,000 \mathrm{mR} / \mathrm{h}$ & -5 to $+10 \%$ \\
\hline Air ion chamber & $B, \gamma$ & $0-5,000 \mathrm{mR} / \mathrm{h}$ & -5 to $+10 \%$ \\
\hline $\begin{array}{l}\text { Thimble-type } \\
\text { air ion chamber }\end{array}$ & $\gamma$ & $\begin{array}{l}0-10,000 \mathrm{R} / \mathrm{h} \\
0-5,000 \mathrm{rads} / \mathrm{h}\end{array}$ & NR \\
\hline $\begin{array}{l}\text { Thimble-type } \\
\text { air ion chamber }\end{array}$ & $\gamma$ & $0-500 \mathrm{R} / \mathrm{h}$ & -5 to $+10 \%$ \\
\hline $\begin{array}{l}\text { Thimble-type } \\
\text { air ion chamber }\end{array}$ & $\gamma$ & $0-50 \mathrm{R} / \mathrm{h}$ & -5 to $+10 \%$ \\
\hline $\begin{array}{l}\text { BF } \text { proportional counter } \\
\text { surrounded by moderator }\end{array}$ & $B, \gamma$ & $0-2,000 \mathrm{mrem} / \mathrm{h}$ & $\pm 25 \%$ \\
\hline Geiger-Muleller & $B, \gamma$ & $0-100,000 \mathrm{cpm}$ & $\mathrm{NA}$ \\
\hline Geiger-Müeller & $B, \gamma$ & $0-500,000 \mathrm{cpm}$ & $\mathrm{NA}$ \\
\hline ZnS scintillator & $\alpha$ & $0-100,000 \mathrm{cpm}$ & $\mathrm{NA}$ \\
\hline Air proportional & $\alpha$ & $0-100,000 \mathrm{cpm}$ & $\mathrm{NA}$ \\
\hline Air proportional & $\alpha$ & $0-500,000 \mathrm{cpm}$ & $\mathrm{NA}$ \\
\hline
\end{tabular}

NOTE: $c p m=$ counts per minute.

$N A=$ not applicable.

$N R=$ not rated . 
condensate stream. Other liquid streams leaving the facility are either not discharged to the environment or are exempt from monitoring requirements because no process wastewater enters that stream. Nevertheless, the following streams are briefly discussed in this chapter:

- Process condensate stream

- Evaporator slurry (treated waste)

- 242-A Building drainage

- Sanitary waste

- 242-A-81 Building drainage

- Storm drain/facility grounds runoff.

4.1.2.1 Used Cooling Water Stream. The 242-A URW waste stream is given the Hanford Site stream code of $A C W$. This waste stream consists primarily of cooling water exiting the primary, intermediate, and after condensers $(E-C-1,-2$, and -3$)$. The proposed waste stream designation is that this stream is not a dangerous waste, pursuant to the WAC 173-303, Dangerous Waste Regulations (WAC 1989). A combination of process knowledge and sampling data was used to make this determination [WHC-EP-0342, Addendum 21, 242-A Evaporator Cooling Water Stream-Specific Report (WHC 1990b)].

Figure 4-3 is a schematic of the URW system. Nine contributors feed the 242-A Evaporator cooling water waste stream. These contributors, in order of volumetric rate contribution to the stream, are as follows.

1. Condenser cooling water $[13,626 \mathrm{~L} / \mathrm{min}(3,600 \mathrm{gal} / \mathrm{min})]--\operatorname{Raw}$ cooling water flows through the condensers. No chemicals are introduced into the water by this cooling process. To ensure flow, the cooling water in each of the three condensers is maintained at a positive pressure of $5.6 \mathrm{~kg} / \mathrm{cm}^{2}\left(801 \mathrm{bf} / \mathrm{in}^{2}\right)$. The vacuum side of the condensers (process condensate side) is maintained with a vacuum of approximately $63.5 \mathrm{~cm}$ (25 in.) of water. This differential pressure across the condenser cooling water tubes prevents the process condensate from entering the cooling water stream in the event of tube leakage. An in-line radiation monitor and proportional sampler $(R-C-2)$ is located downstream of the condensers.

2. Air compressor cooling water $[37.9 \mathrm{~L} / \mathrm{min}(10 \mathrm{gal} / \mathrm{min})]--S i n g l e-p a s s$ raw water cools two air compressors providing process and instrument air. No chemicals are added.

3. Emergency steam turbine condensate $[30.3 \mathrm{~L} / \mathrm{min}(8 \mathrm{gal} / \mathrm{min})$ when running]--Following the loss of the normal HVAC system fan, steam drives an emergency turbine fan that maintains safe ventilation (and air pressure differentials) in the various facility zones. The steam condensate contains only water and nonhazardous carryover chemicals.

4. Steam trap condensate [less than $37.9 \mathrm{~L} / \mathrm{d}(10 \mathrm{gal} / \mathrm{d})$ ]--The HVAC system steam traps feed the HVAC room drain funnel. Steam condensate collected contains no hazardous wastes. Chemicals added to the boiler makeup water contain no hazardous wastes. 
Figure 4-3. Process Configuration for the 242-A Cooling Water Stream.

\begin{tabular}{|c|c|c|c|}
\hline \multicolumn{4}{|c|}{ PIPING ABBREVIATIONS } \\
\hline AF & Antifoam & PS & Process Sewer \\
\hline AS & Alr Sample & PW & Proceses Waste \\
\hline DECON & Decontamination & RW & Aaw Water \\
\hline DA & Drain & SC & Steam Condensate \\
\hline EF & Eveporator Feed & SL & Slurny \\
\hline$E L$ & Eluant & STM & Steam \\
\hline FAW & Filtered Aaw Water & sw & Sanitary Water \\
\hline 1 & Instrument & u & Unility \\
\hline IA & Inatrumant Air & URW & Ueed haw Wator \\
\hline OVFL & Overtlow & $\mathrm{v}$ & Vent \\
\hline $\mathbf{P A}$ & Procese Air & VAC & Vacuum \\
\hline PC & Procesa Condeneme & $\mathbf{V}$ & Vesed/Vent \\
\hline
\end{tabular}

HVAC = Heating, Ventilation, and Air Conditioning

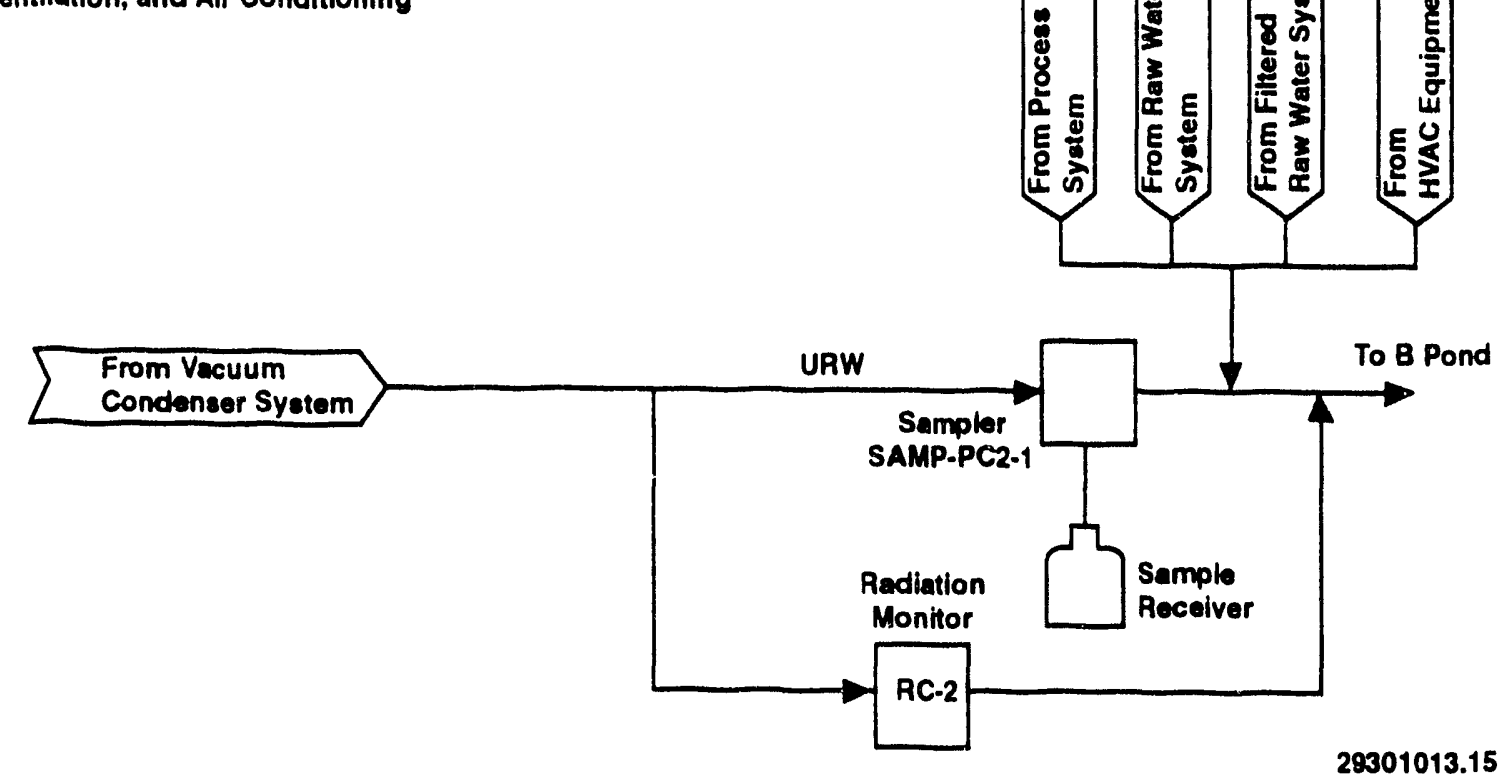


5. Compressed air dryer discharges [less than $37.9 \mathrm{~L} / \mathrm{d}(10 \mathrm{gal} / \mathrm{d})$ ]--An air dryer processes compressed air for use in the instrument air system. No chemicals are added and fresh atmospheric air is filtered before compression.

6. Water filter catch pan drainage [less than $37.9 \mathrm{~L} / \mathrm{d}(10 \mathrm{gal} / \mathrm{d})$ ]--Raw water and oversized particles from the raw water filters are collected in the catch pans. The filters provide filtered water for the deentrainment pads and the desuperheater. No chemicals are introduced. No sampling or monitoring is provided for this effluent stream.

7. HVAC room floor drains [less than $3.785 \mathrm{~L} / \mathrm{d}(1 \mathrm{gal} / \mathrm{d})]$--These floor drains contribute wastewater to the cooling water waste stream on a periodic basis. No chemicals or hazardous materials are stored in the room serviced by the floor drains.

8. Steam system relief valve discharges [less than $3.785 \mathrm{~L} / \mathrm{d}$ (1 gal/d)]--If the HVAC system steam relief valves over pressurize, steam vents to the drain funnel. No hazardous chemicals are contributed by the steam.

9. Compressed air receiver condensate [less than $3.785 \mathrm{~L} / \mathrm{d}(1 \mathrm{gal} / \mathrm{d})$ ]-The air receiver or air storage tank is periodically drained. Air condensate contributes no hazardous waste.

During evaporator processing operations, all nine contributors are potentially adding liquid to the stream. During shutdown and maintenance periods, however, the condenser cooling water and the water filter ci.ch pan drainage will not contribute to the stream. Shutdowns of the facility process operations can vary in length from one month to several months or even years, as in the case of the current facility upgrade shutdown period.

The condenser cooling water from the evaporator subsequently flows into a 61-cm- (24-in.-) diameter pipe where it combines with the other eight contributors to form the overall 242-A Evaporator cooling water effluent stream. This combined effluent is then routed to the 216-B-3 Pond, which receives liquids for soil column disposal. The 216-B-3 Pond covers an area of $123,348 \mathrm{~m}^{2}$ (100 acres) and is used as a percolation pond. Because the condenser cooling water is the only stream with a potential to contribute hazardous waste to the 242-A Evaporator cooling water stream, the effluent discharge point is located (by definition) at the $\mathrm{R}-\mathrm{C}-2$ sampler and monitor point.

4.1.2.2 Steam Condensate Stream. The 242-A Evaporator steam condensate waste stream is given the Hanford Site stream code of ASC. This waste stream consists primarily of steam condensate exiting the reboiler section of the evaporator process. The proposed waste stream designation is that this stream is not a dangerous waste, pursuant to the WAC 173-303, Dangerous Waste Regulations (WAC 1989). A combination of process knowledge and sampling data was used to make this determination. 
As shown in Figure 4-4, 10 contributors feed the 242-A Evaporator steam condensate waste stream:

1. Reboller Steam Condensate: $22.7 \mathrm{~L} / \mathrm{min}(\approx 6 \mathrm{gal} / \mathrm{min})--S t e a m$ is required in the evaporation process to heat the process fluids for evaporation and concentration. Steam pressure is reduced in several stages to the necessary pressure before it enters the $40.6-\mathrm{cm}-$ (16-in.-) diameter feed line to the reboiler. Before use in the reboiler, and to ensure saturation, the steam temperature is lowered by adding filtered raw water in a desuperheater (DS-H-1).

2. Steam Condensate and Raw Water from Heating and Cooling Jackets: $264.95 \mathrm{~L} / \mathrm{h}(70 \mathrm{gal} / \mathrm{h})$--Decontamination Solution Tank TK-E-104 and Eluant Tank TK-E-101 are equipped with heating jackets that allow the contents of these tanks to be maintained at desired temperatures. The flowout of these jackets is combined and discharged into the steam condensate effluent stream.

3. Purging System Steam Trap Condensate: [negligible flow, $3.785 \mathrm{~L} / \mathrm{h}$ $(<1 \mathrm{gal} / \mathrm{h})$ ]--A purging system is used to clear instrument piping needed to obtain specific gravity measurements of tank waste. The steam supply used for this system is equipped with a steam trap that drains into the steam condensate effluent stream.

4. Steam Strainer Condensate: Condensate from the steam strainers in the supply line to the steam ejector system drain into the waste stream. The steam ejectors are used to maintain a vacuum in the evaporator vessel. This condensate flows into a $5-\mathrm{cm}(2-i n$.$) drain$ funnel that drains into the main steam condensate line.

5. Steam Separator Condensate: Condensate from the steam separator in the steam ejector system drains into the waste stream. This condensate flows into the drain funnel.

6. Steam Separator Strainer Blowdown: Condensate from blowdowns of the steam separator strainer flows into the waste stream. This condensate flows into the drain funnel.

7. Seal Water Pressure Control Valve Discharge: Seal water from the process pumps is bled into the waste stream when excessive pressure is present. If the seal water pressure exceeds $10.6 \mathrm{~kg} / \mathrm{cm}^{2}$ (150 $1 \mathrm{bf} / \mathrm{in}^{2}$ ) (gauge), the seal water pressure control valve operis to bleed water to the waste stream. This valve remains open until the pressure is below $10.6 \mathrm{~kg} / \mathrm{cm}^{2}$ (150 $\mathrm{lbf} / \mathrm{in}^{2}$ ) (gauge). The discharge from this stream also flows into the drain funnel.

8. Microfilter Catch Pan Drainage: Drainage from the microfilters drains to a catch pan, which in turn drains to the drain funnel discussed above. These microfilters are required to filter raw water used in the deentrainer pad spray for the evaporator. 
Figure 4-4. 242-A Evaporator Steam Condensate Waste Stream.

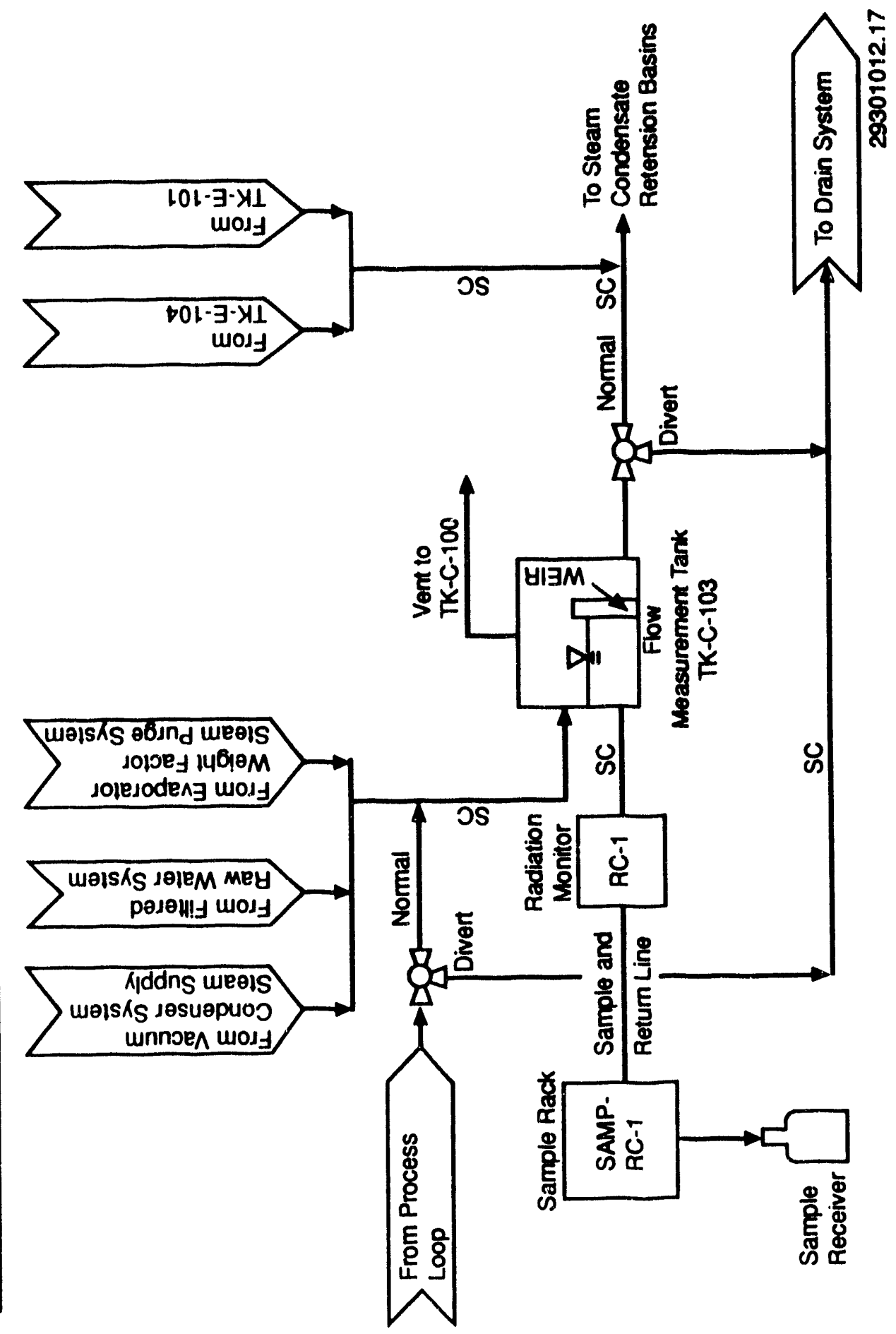


9. Seal Wacer Pumps and Filter Catch Pan Drainage: Leakage from the pump seal water system and drainage from ine seal water pump filters drain into a catch pan and subsequently drain into the waste stream.

10. R-C-1 Sampler/Monitor Cooler Raw-Water Discharge: $37.9 \mathrm{~L} / \mathrm{h}$ (10 gal/h)--Raw water used in the cooler for the R-C-1 sampler drains into the main condensate line to Tank C-103.

All contributors to the waste stream, except the heating and cooling jacket streams for eluant Tanks TK-E-101 and TK-E-104, converge and then pass through ar in-line radiation monitor (RE-EAl-1) before flowing into a 1,892.5-L (500-gal) flow measuring tank (TK-C-103). Diversion valves are provided before the flow measurement tank (valve HV-EAl-2) and after the tank (valve HV-RC1-3). These valves are capable of diverting the flow to the process drain system and ultimately to the waste feed tank (241-AW-102 DST) in the case of an upset condition, particularly if high radiation is detected in the stream. These valves direct stream flow to the 207-A Retention Basins during normal operations.

The steam condensate flows into one of the three cells at the 207-A Retention Basins until that cell has reached operational capacity. At that time the steam condensate flow is diverted to one of the two remaining cells. Samples are taken at the RC-1 sampler. These samples are analyzed at the 222-S Laboratory for radionuclides as an indication of process control (refer to Chapter 9 or the 222-S Laboratory FEMP for more information on procedures and analytical methods). The steam condensate from the full cell is then discharged to the B-3-3 Pond (located northeast of the 200 East Area) if the analytical results are within set radionuclide limits.

The effluent discharge point for the 242-A Evaporator steam condensate stream is located at the 207-A Retention Basins sample point. This is the point where final sampling and diversion capabilities exist for the stream before discharge to the environment.

4.1.2.3 Process Condensate Stream. The 242-A Evaporator process condensate waste stream is given the Hanford Site stream code AFPC. This waste stream is a collection of the condensable materials carried over from the evaporation process into the condensers. These materials collect within the facility in Tank TK-C-100 where they are pumped out for filtration of radionuclides and disposal. The proposed waste stream designation for the 242-A Evaporator process condensate waste stream is that this stream is a dangerous waste, pursuant to the WAC 173-303, "Dangerous Waste Regulations" (WAC 1989). A combination of process knowledge and sampling diata was used to make this determination.

Process condensate from the 242-A Evaporator will be stored temporarily at the LERF that is currently under construction. The waste will be stored until a proposed ETF is operational. The ETF is under design at this time. The LERF consists of three identical 24.6-ML (6.5-Mgal) surface impoundments (retention basins). Two of the basins will be used to store process condensate (PC). The third will be kept empty and used as contingency space. The process condensate waste stream will be piped directly through dualencasement buried lines to the treatment facility when it is operational. 
Following treatment, the stream will be disposed of to a Washington Stateapproved soil dispesal site or to the Columbia River.

For the purposes of this FEMP, the 242-A Evaporator process condensate stream is not considered as a facility effluent because it will not be discharged/released to the environment. For more information concerning the process condensate stream, reference may be made to WHC-EP-0342, Addendum 15, 242-A Evaporator Process Condensate Stream-Specific Report (WHC 1990C).

4.1.2.4 Evaporator Slurry Stream. The evaporator slurry stream is the treated waste stream from the facility that contains essentially all of the radionuclides and inorganic constituents. After treatment in the vapor-liquid separator, the waste (slurry) is transferred through two encased lines (pipein-pipe) from the 242-A Evaporator to one of two valve pits in the 242-AW Tank Farm. The two encased lines are equipped with leak detectors between the primary and encasement piping. The detection of any leak will automatically shut off the slurry pump, thus preventing leaks into the environment.

For the purposes of this FEMP, the evaporator slurry (treated waste) stream is not considered as an effiuent because it is fed back through dualencasement transfer lines into the DST system for further treatment. This stream is not discharged to the environment.

4.1.2.5 242-A Building Drainage Stream. Four branches of the drainage piping system provide drainage for the 242-A Evaporator building. Figure 4-5 presents a flow diagram of the drainage system.

The first branch is a $15.2-\mathrm{cm}-(6-$ in.-) dia, schedule 40 , carbon steel pipe that drains the AMU, the survey room, the condenser room, and the ion exchange column room.

The second branch is a schedule 405 , stainless steel pipe ranging in diameter from 3 to 10 in. This branch drains the loading room, the loadout and hot equipment storage room, the HVAC room, and other miscellaneous drains to the pump room sump, which is located in the northwest corner of the pump room. The following streams drain to the pump room sump:

- Loading room 7.6-cm (3-in.) floor drain

- Ten-inch raw-water line backflow preventer drain

- Slurry pump drip pan

- Slurry pump seal water

- Recirculation pump seal water

- Feed sample drain

- Slurry sample drain

- Evaporator room 7.6-cm (3-in.) floor drain:

- Vacuum breaker drain

- Filtered raw-water line backflow preventer drain

- Two-inch raw-water line backflow preventer drain

- Two-inch decontamination line vacuum breaker drain.

From the sump, liquids are either moved to the feed tank (241-AW-102) using a sump jet gang valve system or allowed to drain by gravity. 
Figure 4-5. 242-A Evaporator Drain System.
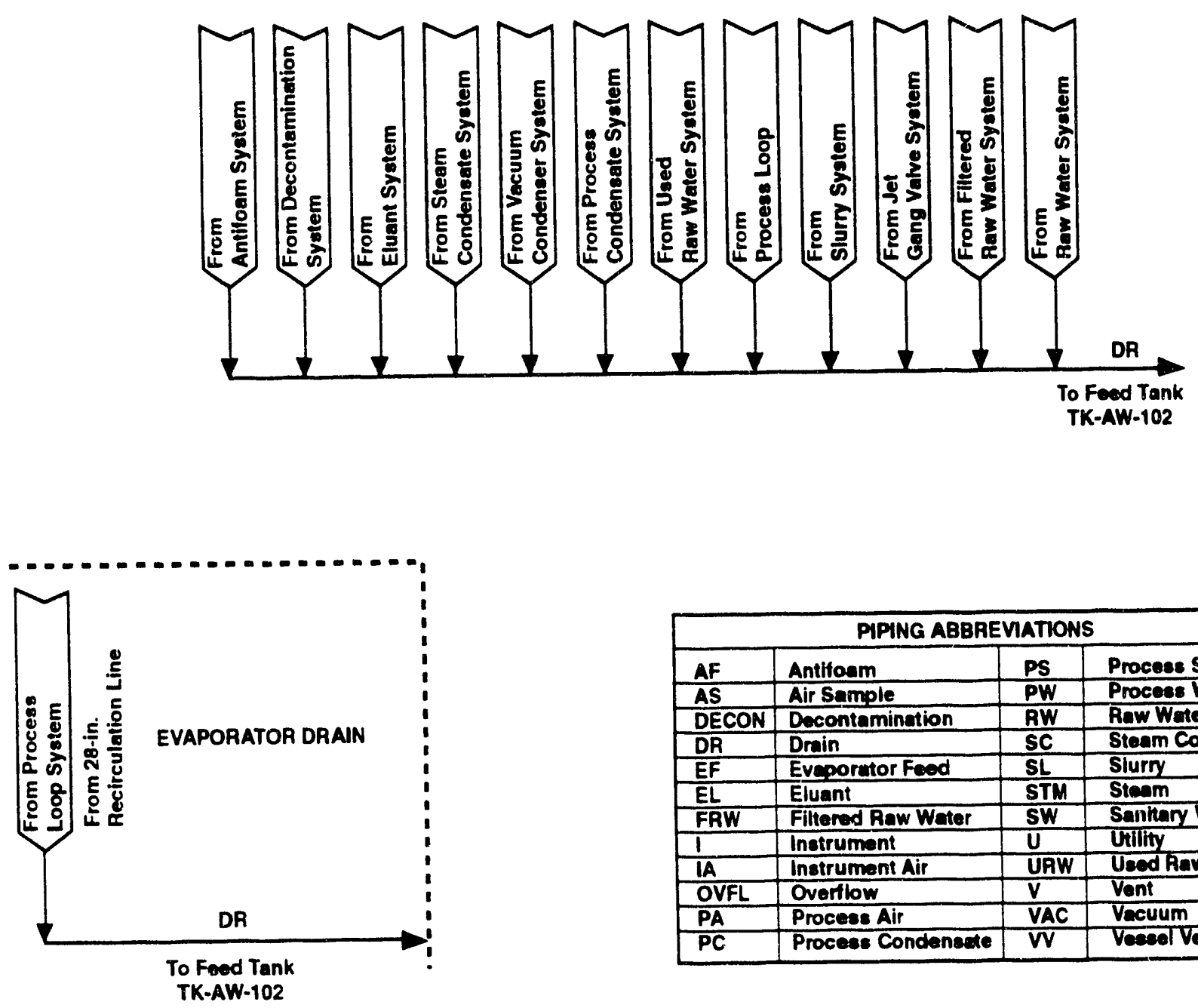

\begin{tabular}{|c|c|c|c|}
\hline \multicolumn{4}{|c|}{ PIPING ABBREVIATIONS } \\
\hline $\mathbf{A F}$ & Antifoam & PS & Procees Semer \\
\hline AS & Air Sample & PW & Procese Wacte \\
\hline DECON & Docontamination & RW & Raw Weter \\
\hline DR & Drain & SC & Steam Condunerte \\
\hline EF & Eveporutor Feed & $\mathbf{S L}$ & Slurry \\
\hline$E L$ & Eluant & STM & Stam \\
\hline FRW & Filtered Raw Water & SW & Santary Weter \\
\hline$T$ & Instrument & $\mathbf{U}$ & Unility \\
\hline IA & Instrument Air & UAW & Used Aaw Water \\
\hline OVFL & Overtlow & $\mathrm{v}$ & Vent \\
\hline PA & Procese Air & VAC & Vacuum \\
\hline$\overline{P C}$ & Procese Condenste & $\mathbf{V}$ & Veesed Vent \\
\hline
\end{tabular}

29301012.14 
The third drain branch is a $7.6 \mathrm{~cm}-(3-i n-)$ diameter, schedule 40 , carbon steel pipe that drains the ion exchange column. The drain is encased in a 15.2-cm-(6-in.-) dia pipe for secondary containment when it exits the building. The pipe joins the pump room sump drain outside the building.

The fourth drain has a remotely operated valve (HV-CAl-7) that allows the vapor-liquid separator to be drained to the feed tank from a connection on the recirculation line. The drain is a $304 \mathrm{~L}$ stainless steel schedule $40 \mathrm{~S}$ pipe. Outside the 242-A Building, the pipe diameter is increased to $25.4 \mathrm{~cm}$ (10 in.) and encased in a $30.5-\mathrm{cm}-(12-\mathrm{in.}-)$ diameter carbon steel pipe for secondary containment.

All waste liquids, which enter the building drainage piping, gravity drain with sufficient hydraulic head to the 242-A Evaporator feed tank (TK 241-AW-102). Thus, loss of facility power does not affect the ability of the system to contain waste or waste constituents.

For the purposes of this FEMP, the 242-A Building drainage stream is not considered an effluent because it is fed back through dual-encasement transfer lines into the DST system for further treatment. This stream is not discharged to the environment.

4.1.2.6 242-A Building Sanitary Waste Stream. Nonradiological, nonhazardous liquid wastes are emitted from the 242-A facility via the sanitary sewer. The sanitary sewer flow originates in the men's and women's change room from the toilets, showers, and wash basins. The sewer line extends underground east of the 242-A Evaporator facility and under Canton Street to an underground septic tank and tile field ground disposal system.

The sanitary sewer system is isolated from the other facility systems. The only radioactive discharge that might reasonably occur would result from inadequate survey of personnel leaving contaminated areas and their subsequent bathing. The release to the environment under these circumstances would be negligible. To prevent this situation from occurring, personal surveys are conducted by trained health physics technicians at ail step-off pads.

Administrative controls prohibit the dumping of chemicals into the 242-A Evaporator sanitary sewer system. Contributors to this stream are considered nonhazardous.

4.1.2.7 242-A-81 Building Drainage. Liquids collected in the 242-A-81 RawWater Building are drained from the building via a $15.2-\mathrm{cm}-(6-$ in.-) diameter carbon steel pipe to a $30.5-\mathrm{cm}-(12-$ in.-) diameter chemical sewer serving the 200 East Area. No hazardous materials enter Building 242-A-81. The building is not used for storage and is kept locked. The building has no potential for contributing hazardous wastes to this stream.

4.1.2.8 Storm Drain and Facility Grounds Runoff. The 242-A facility grounds have sufficient slope to allow storm runoff to drain with gravity flow to its perimeter. There are no underground storm drains at the grounds. Because the building itself is designed and exists as a containment system for all process liquids, there is no contribution of radioactive or hazardous materials to this stream. 


\subsubsection{2-A Building Solid Waste}

Solid waste from the facility consists primarily of laundry, rubber gloves, paper, plastics, and failed or replaced HEPA filters. The rubber gloves, paper, and plastics must be disposed of in accordance with WHC-CM-5-16, Hazardous Waste Management (WHC 1989b). These wastes are usually low-level radioactive wastes. Currently, low-level solid waste is stored at the BX Tank Farm in the 200 East Area. Failed or replaced HEPA filters, as well as other process equipment, must be packed and buried in accordance with WHC-CM-5-16. Laundry is collected daily and stored temporarily until it can be sent to the laundry.

Laundry, if contaminated above allowable levels (radiation protective clothing contaminated in excess of 40,000 disintegrations per minute alpha or $50 \mathrm{mRad} / \mathrm{h}$ ), must be disposed of as contaminated waste. If below disposal limits, it is labelled appropriately and sent to the laundry for cleaning.

Uncontaminated, nonhazardous wastes are buried at the central landfill. The nonradioactive, nonhazardous solid wastes are manually collected in standard waste containers, plastic bags, and paper board boxes. These containers are emptied into a dumpster. The dumpsters are periodically emptied into large compactor trucks, where the waste is compacted and transported to the Hanford Site central landfill. Periodically, the nonhazardous, nonradioactive wastes are monitored by an HPT to ensure that the wastes are nonradioactive. During monitoring by the HPT, a visual check is made to ensure that the solid wastes do not contain hazardous materials. A sample is taken of solid waste when the presence of hazardous materials is suspected. If the sample results confirm that the waste contains hazardous materials at concentrations above the requirements found with in WAC 173-303 (WAC 1989), the waste is designated as nonradioactive, hazardous waste, accumulated in approved 208-L (55-gal) containers and stored in the 200 West Area until the drum can be transported offsite to a state-approved hazardous waste burial site.

\subsection{IDENTIFICATION AND CHARACTERIZATION OF SOURCE TERMS CONTRIBUTING TO EACH EFFLUENT STREAM}

There are four effluent streams discharged into the environment from the 242-A Evaporator (as described in the previous section) that require further examination. These streams are the focus of the rest of this FEMP. These streams are as follows:

- The airborne effluent stream discharged from the vessel vent stack (296-A-22)

- The airborne effluent stream discharged from the building exhaust stack (296-A-21)

- The liquid steam condensate effluent stream

- The liquid used cooling water effluent stream. 
This section is provided to characterize the discharges of these streams during both nominal and upset conditions. Historical data are used for this purpose. Chapters 6 through 9 discuss the monitoring and sampling performed on these streams.

\subsubsection{Routine Operating Conditions}

This section characterizes the effluents from the four streams during nominal conditions. The radionuclide characterization for the vessel vent and the building ventilation provides calculations of the resulting offsite dose.

4.2.1.1 Vessel Vent Stack (296-A-22). Radionuclide emission data from the evaporator vessel vent stack 296-A-22 during nominal conditions are presented in Section 8.1.1, Table 8-1.

The data presented in Table 8-1 were used to create Table 4-2. Table 4-2 contains the maximum offsite dose that could result from the data 1 isted in Table 8-1. Because specific radionuclide emission data are not presented in Table 8-1 for all the years listed, a direct determination of the maximum curie release for one year was not, by simple comparison, judicious. Likewise, a comparison of 1988 and 1989 values was not prudent because the evaporator did not operate for an entire year in 1989. As a result, the derivation of the maximum radionuclide amount (curies) released for a year presented in Table 4-2 was determined in the following way.

- First, the maximum annual volumetric flow from all the years listed in Table 8-1 (total volume $=1.03 \times 10^{+10} \mathrm{~L}$ ) was used.

- Second, the maximum specific radionuclide concentration that was discharged was used.

- Finally, these two values were multiplied together, giving the maximum possible total release, in curies, that could result using the data furnished in Table 8-1.

The "Annual release with controls" column represents these calculations. The "Annual release without controls" column gives the values that could result if the HEPA filters were not in place. This value is 3,000 times the value of the previous column. The multiplication factor of 3,000 is based on a $99.97 \%$ HEPA filter efficiency and, typically, has been the factor used at Hanford in determining a worst case release scenario involving HEPA failure. The CAP-88 conversion factor is from an approved EPA computer modeling program.

Table 4-3 is presented only for comparison with the Table 4-2 offsite dose calculations. Table 4-3 shows that if only alpha and beta analyses are used to determine the offsite dose, a lower value is obtained. This leads to the conclusion that offsite dose calculations from alpha and beta analyses alone may not be sufficient or accurate enough. 
Table 4-2. Stack 296-A-22 Gaseous Radioactive Effluent Emissions.

\begin{tabular}{|l|r|r|r|r|r|r|}
\hline Emission & $\begin{array}{c}\text { Maximum } \\
(\mu \mathrm{Ci} / \mathrm{mL})\end{array}$ & $\begin{array}{c}\text { Annual } \\
\text { release } \\
\text { with } \\
\text { controls } \\
(\mathrm{Ci})\end{array}$ & $\begin{array}{c}\text { Annual } \\
\text { release } \\
\text { without } \\
\text { controls } \\
(\mathrm{Ci})\end{array}$ & $\begin{array}{c}\text { CAP-88 } \\
\text { conversion } \\
\text { factor }\end{array}$ & $\begin{array}{r}\text { CAP-88 } \\
\text { offsite } \\
\text { dose } \\
(\mathrm{mrem})\end{array}$ & $\begin{array}{c}\text { \% of } \\
\text { total } \\
\text { dose }\end{array}$ \\
\hline${ }^{137} \mathrm{Cs}$ & $1 \mathrm{E}-14$ & $1.03 \mathrm{E}-07$ & 0.0003 & $2.39 \mathrm{E}-02$ & $7.39 \mathrm{E}-06$ & 0.006 \\
\hline${ }^{129} \mathrm{I}$ & $2 \mathrm{E}-11$ & $2.06 \mathrm{E}-04$ & $2.06 \mathrm{E}-04^{1}$ & $2.91 \mathrm{E}-01$ & $6.0 \mathrm{E}-05$ & 0.05 \\
\hline${ }^{106} \mathrm{Ru}$ & $2 \mathrm{E}-10$ & $2.06 \mathrm{E}-03$ & 6.18 & $2.09 \mathrm{E}-02$ & 0.13 & 98.9 \\
\hline${ }^{103} \mathrm{Ru}$ & $4 \mathrm{E}-14$ & $4.12 \mathrm{E}-7$ & 0.0012 & $1.42 \mathrm{E}-03$ & $1.76 \mathrm{E}-6$ & 0.001 \\
\hline${ }^{113} \mathrm{Sn}$ & $4 \mathrm{E}-13$ & $4.12 \mathrm{E}-06$ & 0.012 & $1.18 \mathrm{E}-03$ & $1.46 \mathrm{E}-05$ & 0.01 \\
\hline${ }^{89,90} \mathrm{Sr}$ & $4 \mathrm{E}-14$ & $4.12 \mathrm{E}-07$ & 0.0012 & $4.38 \mathrm{E}-02^{2}$ & 0.0001 & 0.08 \\
\hline${ }^{125} \mathrm{Sb}$ & $1 \mathrm{E}-11$ & $1.03 \mathrm{E}-04$ & 0.31 & $4.15 \mathrm{E}-03$ & 0.0013 & 1.0 \\
\hline \multicolumn{1}{|l}{ Total offsite dose } & & & 0.13 & \\
\hline
\end{tabular}

${ }^{1}$ The 3000 factor is not used here because iodine is gaseous and would pass through the HEPA filters. The quantity of iodine released should, therefore, be the same with or without. HEPA filters.

${ }^{2}$ Conversion factor good for ${ }^{90} \mathrm{Sr}$ only. ${ }^{89} \mathrm{Sr}$ is not listed.

The following information is provided to help the reader understand the units used in Tables 4-2 and 4-3:

- $\mathrm{Ci}$ is an abbreviation for curie which is the unit used for measuring radioactivity

- $\mathrm{A} \mu \mathrm{Ci}$ is $1 / 1,000,000$ of a curie

- A mL is $1 / 1000$ of a liter.

Table 4-3. Stack 296-A-22 Offsite Dose Cross-Check.

\begin{tabular}{|l|c|c|r|r|r|r|}
\hline Emission & $\begin{array}{c}\text { Maximum } \\
(\mu \mathrm{C} \mathrm{i} / \mathrm{mL})\end{array}$ & $\begin{array}{c}\text { Annual } \\
\text { release } \\
\text { with } \\
\text { controls } \\
(\mathrm{Ci})\end{array}$ & $\begin{array}{c}\text { Annual } \\
\text { release } \\
\text { without } \\
\text { controls } \\
(\mathrm{Ci})\end{array}$ & $\begin{array}{c}\text { CAP-88 } \\
\text { conversion } \\
\text { factor }\end{array}$ & $\begin{array}{c}\text { CAP-88 } \\
\text { offsite } \\
\text { dose } \\
\text { (mrem) }\end{array}$ & $\begin{array}{c}\% \text { of } \\
\text { total } \\
\text { dose }\end{array}$ \\
\hline Alpha & $1.9 \mathrm{E}-14$ & $2.0 \mathrm{E}-7$ & 0.0006 & $13.1^{*}$ & 0.0079 & 59.8 \\
\hline Beta & $4.0 \mathrm{E}-12$ & $4.12 \mathrm{E}-5$ & 0.12 & $0.0438^{* *}$ & 0.0053 & 40.2 \\
\hline \multicolumn{7}{l|}{ Total offsite dose }
\end{tabular}

*Using ${ }_{90}^{241} \mathrm{Am}$ as the alpha emitter.

$\star *$ Using ${ }^{90} \mathrm{~S} r$ as the beta emitter. 
WHC-EP-0466-1

vessel vent stack of the 242-A Evaporator was sampled for potential tritium emissions in 1989. The analytical results of the sampling that was conducted are discussed in Internal Memo 12715-ASL-136 (WHC 1989d).

This memo describes results of stack sampling conducted on February 7 and 8, 1989, and on March 1 and 7, 1989. The sampling was done to determine if continuous monitoring for tritium might be required. The sample analyses determined the concentration of tritium in the stack gases to be $8.9 \times 10^{-09} \mu \mathrm{Ci} / \mathrm{mL}$. The maxinum determined annual total flow through the vessel vent stack, as determined by Table $8-1$, was $1.03 \times 10^{+10} \mathrm{~L}$. Multiplication of the determined tritium concentration value by the maximum annual total flow will result in an annual release of $9.2 \times 10^{-02} \mathrm{Cj}$ of tritium. To determine the offsite dose contributed by the tritium constituent, the annual tritium release (in curies) must be determined with no engineering controls in place [as required by 40 CFR 61.93 (EPA 1991b)]. Tritium is gaseous, and the HEPA filters would probably not prevent it from being released. Multiplying the calculated annual release of $9.2 \times 10^{-02} \mathrm{Ci}$ by the CAP-88 computer code offsite conversion factor of $2.19 \times 10^{-05}$ results in an offsite dose for tritium from the 242-A Evaporator Vessel Vent of $2.0 \times$ $10^{-06} \mathrm{mrem}$. Comparing this value to the other radionuclide offsite dose values tabulated in Table 4-2 and performing the necessary computations results in a tritium contribution to the stream offsite dose of less than $0.002 \%$. Therefore, by rule, radionuclide tritium need not be specifically sampled in the 242-A Evaporator vessel vent stack effluent because its contribution to the stream offsite dose is less than the $10 \%$ required for monitoring as specified in 40 CFR 61.93, Emission Monitoring and Test Procedures (EPA 1991b).

\subsection{Nonradionuclide Emissions From the Vessel Vent Stack.}

Nonradionuclide analysis data are not currently available for the vessel vent effluent. However, emission calculations were provided for certain chemicals by Westinghouse Environmental \& Geotechnical Services, Inc.

Nonradionuclide emissions originate as gases in the process condensate collection tank (Tank $\mathrm{C}-100)$. These gases are vented and released through the vessel vent stack. The highest permitted temperature in the process condensate collection tank is $145^{\circ} \mathrm{F}(335 \mathrm{~K})$. An alarm is set to activate at this temperature. Using this fact and figures prepared as part of a model in DOE/RL-90-42 (DOE-RL 1990), Table 4-4 was developed and shows what might be released. The second and third columns in this table are equivalent, but use different units and release times. The third column is important because it shows how much might be released in a 24-h period. The last column within this table contains the CERCLA RQ limits. The quantities are not sufficient to cause concern. However, these values are provided for completeness.

Release data for anmonia are available. Ammonia samples (Drager tube* samples) were taken from the vessel vent system between the dates of January 1, 1989, and March 24, 1989. For each sample, ammonia releases were in average of $0.36 \mathrm{~kg}(0.797 \mathrm{ib})$ and a maximum of $19.5 \mathrm{~kg}(42.875 \mathrm{lb})$. A mean

*Drager tube is a trademark of Dragerwerk, AG. 
Tabie 4-4. Stack 296-A-22 Gaseous Nonradioactive Emissions.

\begin{tabular}{|l|c|c|c|}
\hline \multicolumn{1}{|c|}{ Chemical } & $\begin{array}{c}\text { Emission rate } \\
\text { at maximum } \\
\text { concentration } \\
\text { of }\end{array}$ & $\begin{array}{c}\text { Maximum daily } \\
\text { emission } \\
\text { rate } \\
(1 \mathrm{~b} / \mathrm{h})\end{array}$ & $\begin{array}{c}\text { CERCLA } \\
\text { reportable } \\
\text { quantity } \\
(\mathrm{kg} / 24 \mathrm{~h})\end{array}$ \\
\hline Acetone & $2.42 \mathrm{E}-2$ & 0.2640 & 2,270 \\
\hline $\begin{array}{l}\text { 1-Butanol or } \\
\text { butyl alcohol }\end{array}$ & $1.817 \mathrm{E}-1$ & 1.9822 & 2,270 \\
\hline $\begin{array}{l}\text { 2-Hexanone } \\
\begin{array}{l}\text { Methyl isobutyl } \\
\text { ketone (MIBK- } \\
\text { Hexone) }\end{array}\end{array}$ & $8.727 \mathrm{E}-5$ & 0.0010 & none \\
\hline
\end{tabular}

rate was calculated as $0.36 \mathrm{~kg} / \mathrm{d}(0.797 \mathrm{lb} / \mathrm{d})$ [reference: Internal Memo 1331-90-012; (WHC 1990f)]. The total amount of ammonia released from the Evaporator Stack in 1989, as reported in the Superfund Amendments and Reauthorization Act of 1986 (SARA) 313 Report, was 59 1b (the 1988 quantity was $200 \mathrm{lb})$.

4.2.1.2 Building Ventilation Stack (296-A-21). Airborne effluents from the building process and support zones are discharged to the atmosphere via the 296-A-21 Building ventilation stack. Historical radionuclide emission data from this stack are presented in Section 8.1.2, Table 8-2.

Table 4-5 contains the maximum offsite dose that could result from the data 1 isted in Table 8-2. Because specific radionuclide emission data are not presented in Table 8-2 for all the years listed, a direct determination of the maximum curie release for one year was not, by simple comparison, judicious. Likewise, a comparison of 1988 and 1989 values was not prudent because the evaporator did not operate for an entire year in 1989. As a result, the derivation in the maximum radionuclide amount (curies) released for a year presented in Table 4-5 was determined in the following way:

- First, the maximum annual volumetric flow from all the years 1 isted in Table $8-2$ (total volume $=2.90 \times 10^{+11} \mathrm{~L}$ ) was used.

- Second, the maximum specific radionuclide concentration that was discharged was used.

- Finally, these two values were multiplied together, giving the maximum possible total release, in curies, that could result using the data furnished in Table 8-2.

The "Annual release with controls" column represents these calculations. The "Annual release without controis" column gives the vaiues that could result if the HEPA filters were not in place. This value is 3,000 times the value of the previous column. The multiplication factor of 3,000 is based on 
Table 4-5. Stack 296-A-21 Gaseous Radioactive Effluent Emissions.

\begin{tabular}{|l|c|c|c|c|c|c|}
\hline Emission & $\begin{array}{c}\text { Maximum } \\
(\mu \mathrm{Ci} / \mathrm{mL})\end{array}$ & $\begin{array}{c}\text { Annual } \\
\text { release } \\
\text { with } \\
\text { controls } \\
(\mathrm{Ci})\end{array}$ & $\begin{array}{c}\text { Annual } \\
\text { release } \\
\text { without } \\
\text { controls } \\
(\mathrm{Ci})\end{array}$ & $\begin{array}{c}\text { CAP-88 } \\
\text { conversion } \\
\text { factor }\end{array}$ & $\begin{array}{c}\text { CAP-88 } \\
\text { offsite } \\
\text { dose } \\
\text { (mrem) }\end{array}$ & $\begin{array}{c}\% \text { of } \\
\text { total } \\
\text { dose }\end{array}$ \\
\hline${ }^{241} \mathrm{Am}$ & $2.2 \mathrm{E}-14$ & $6.38 \mathrm{E}-06$ & 0.0191 & 13.1 & 0.25 & 95.7 \\
\hline${ }^{239,240 \mathrm{Pu}}$ & $1.5 \mathrm{E}-15$ & $4.35 \mathrm{E}-07$ & 0.0013 & 8.67 & 0.0113 & 4.3 \\
\hline \multicolumn{2}{|l}{ Total off } \\
\hline
\end{tabular}

a $99.97 \%$ HEPA filter efficiency and, typically, has been the factor used at the Hanford Site to determine a worst case release scenario involving HEPA failure. The CAP-88 conversion factor is from an approved EPA computer modeling program.

The following information is provided to help the reader understand the units used in the following tables.

- $\mathrm{Ci}$ is an abbreviation for curie, the unit used for measuring radioactivity.

- $A \mu C i$ is $1 / 1,000,000$ of a curie.

- A mL is $1 / 1000$ of a liter.

Table 4-6 is presented for comparison with the Table 4-5 offsite dose calculations. Table 4-6 shows that if only alpha and beta analyses are used to determine the offsite dose, a lower value is obtained. This leads to the conclusion that offsite dose calculations from alpha and beta analyses alone may not be sufficient or accurate enough.

Table 4-6. Stack 296-A-21 Offsite Dose Cross-Check.

\begin{tabular}{|c|c|c|c|c|c|c|}
\hline Emission & $\begin{array}{l}\text { Maximum } \\
(\mu \mathrm{Ci} / \mathrm{mL})\end{array}$ & $\begin{array}{l}\text { Annual } \\
\text { release } \\
\text { with } \\
\text { controls } \\
\text { (Ci) }\end{array}$ & $\begin{array}{c}\text { Annual } \\
\text { release } \\
\text { without } \\
\text { controls } \\
(\mathrm{C} i)\end{array}$ & $\begin{array}{l}\text { CAP-88 } \\
\text { conversion } \\
\text { factor }\end{array}$ & $\begin{array}{l}\text { CAP-88 } \\
\text { offsite } \\
\text { dose } \\
\text { (mrem) }\end{array}$ & $\begin{array}{l}\% \text { of } \\
\text { total } \\
\text { dose }\end{array}$ \\
\hline Alpha & $3.9 E-15$ & $1.13 \mathrm{E}-6$ & 0.0034 & $13.1 *$ & 0.0444 & 81.2 \\
\hline Beta & $2.7 \mathrm{E}-13$ & 0.0001 & 0.2349 & $0.0438 * *$ & 0.0103 & 18.8 \\
\hline \multicolumn{5}{|c|}{ Total offsite dose } & 0.0547 & \\
\hline
\end{tabular}

*Using ${ }_{90}^{24} \mathrm{Am}$ as the alpha emitter.

$* *$ Using ${ }^{90} \mathrm{Sr}$ as the beta emitter. 
4.2.1.3 Steam Condensate. Radionuclide source term data for the 242-A Evaporator steam condensate stream are presented in Section 8.1.3, Table 8-3.

Column (2) in Table 4-7 contains the maximum values 1isted in Table 8-3.

Column (3) contains data from WHC-EP-0342, Addendum 26, 242-A Evaporator Steam Condensate Stream-Specific Report (WHC 1990).

From these two columns, the maximum specific radionuclide release, in curies, over a 24-h period were calculated. This was done by taking (from Table 8-3) the maximum recorded flow for the year $\left(8.5 \times 10^{\text {to }} \mathrm{L}\right)$ and dividing this figure by $365 \mathrm{~d} / \mathrm{y}$ to give a daily flow rate of $232,876 \mathrm{~L} / \mathrm{d}$. This value was used to calculate the figures in the next column (4)

Table 4-7. Steam Condensate Radionuclide Source Terms.

\begin{tabular}{|c|c|c|c|}
\hline $\begin{array}{c}\text { (1) } \\
\text { Effluent }\end{array}$ & $\begin{array}{l}\text { (2) } \\
\text { Maximum from } \\
\text { Table 8-3 } \\
(\mu \mathrm{Ci} / \mathrm{mL})\end{array}$ & $\begin{array}{c}(3) \\
\text { WHC-EP-0342 } \\
(\mu C \mathrm{C} / \mathrm{mL})\end{array}$ & $\begin{array}{l}(4) \\
\text { Maximum } \\
24-h \\
\text { release } \\
\text { (Ci) }\end{array}$ \\
\hline Alpha & 9.1 E-09 & 9.44 E-10 & 2.12 E-06 \\
\hline Beta & $8.5 E-08$ & $6.27 E-09$ & $1.98 \mathrm{E}-05$ \\
\hline${ }^{14} \mathrm{c}$ & & $4.5 E-09$ & 1.05 E-06 \\
\hline $3 \mathrm{H}$ & $1.2 \mathrm{E}-04$ & & 0.028 \\
\hline${ }^{137} \mathrm{cs}$ & 7 E-08 & & $1.63 \mathrm{E}-05$ \\
\hline Uranium & 2.9 E-09 & & $6.75 E-07$ \\
\hline $234 \mathrm{U}$ & & $2.01 E-10$ & $4.68 E-08$ \\
\hline $238 \mathrm{U}$ & & $1.78 E-10$ & $4.14 E-08$ \\
\hline $239,240 \mathrm{Pu}$ & $1.3 E-08$ & & $3.03 \mathrm{E}-06$ \\
\hline $89,90 \mathrm{sr}$ & 2 E-08 & $6.88 E-10$ & 4.66 E- 06 \\
\hline
\end{tabular}

Table 4-8 contains the nonradionuclide source term for the 242-A Evaporator steam condensate stream. The data in this table were obtained from WHC-EP-0342, Addendum 26, 242-A Evaporator Stealn Condensate Stream-Specific Report (WHC 1990d).

From Table 8-3, the maximum yearly total recorded flow was $8.5 \times 10^{+07} \mathrm{~L}$. This figure divided by $365 \mathrm{~d} / \mathrm{y}$ gives a daily flow rate of $232,876 \mathrm{~L} / \mathrm{d}$. This value was used to determine if the CERCLA RQ values are exceeded.

The following information is provided to help the reader understand the units used in the table below.

- "g" is the abbreviation for gram.

- "kg" is the abbreviation for kilogram and is equal to 1,000 $\mathrm{g}$.

- " $L "$ is the abbreviation for liter. 


\section{WHC-EP-0466-1}

- " $\mathrm{mL} "$ is the abbreviation for milliliter. $1,000 \mathrm{~mL}$ are equivalent to 1 1iter.

- "ppb" is the abbreviation for parts per billion.

Table 4-8. Steam Condensate Nonradionuclide Source Terms. (2 sheets)

\begin{tabular}{|l|r|r|r|}
\hline \multicolumn{1}{|c|}{ Chemical } & $\begin{array}{c}\text { Concentration } \\
\text { (ppb) }\end{array}$ & $\begin{array}{c}\text { Daily release } \\
\text { rate } \\
\text { (kg/d) }\end{array}$ & $\begin{array}{c}\text { CERCLA } \\
\text { reportable } \\
\text { quantity } \\
\text { (kg/d) }\end{array}$ \\
\hline Aluminum & 180 & 0.042 & none \\
\hline Ammonia & 51 & 0.019 & 45.4 \\
\hline Arsenic (EP toxic) & 500 & 0.12 & 0.454 \\
\hline Barium & 33 & 0.0077 & 454 \\
\hline Barium (EP toxic) & 1,000 & 0.23 & 454 \\
\hline Boron & 23 & 0.0054 & none \\
\hline Calcium & 20,700 & 4.82 & none \\
\hline Cadmium & 4 & 0.0009 & 4.54 \\
\hline Cadmium (EP toxic) & 100 & 0.023 & 4.54 \\
\hline Chloride (Cl-) & 1,300 & 0.30 & none \\
\hline Chromium & 10 & 0.0023 & 2,270 \\
\hline Chromium (EP toxic) & 500 & 0.1164 & 2,270 \\
\hline Copper & 13 & 0.0030 & 2,270 \\
\hline Fluoride (F-) & 132 & 0.031 & none \\
\hline Iron & 211 & 0.049 & none \\
\hline Lead (EP toxic) & 500 & 0.1164 & 0.454 \\
\hline Lead & 7 & 0.0016 & 0.454 \\
\hline Magnesium & 4,710 & 1.097 & none \\
\hline Manganese & 42 & 0.0098 & none \\
\hline Mercury (EP toxic) & 20 & 0.0047 & 0.454 \\
\hline Mercury & 2.79 E-05 & 0.454 \\
\hline Nickel & 0.0033 & 0.454 \\
\hline Nitrate (NO - $^{-}$) & 0.12 & 0.14 & none \\
\hline Potassium & & & none \\
\hline
\end{tabular}


Table 4-8. Steam Condensate Nonradionucl ide Source Terms. (2 sheets)

\begin{tabular}{|c|c|c|c|}
\hline Chemical & $\begin{array}{c}\text { Concentration } \\
(\mathrm{ppb})\end{array}$ & $\begin{array}{c}\text { Daily release } \\
\text { rate } \\
(\mathrm{kg} / \mathrm{d})\end{array}$ & $\begin{array}{c}\text { CERCLA } \\
\text { reportable } \\
\text { quant ity } \\
(\mathrm{kg} / \mathrm{d})\end{array}$ \\
\hline Selenium (EP toxic) & 500 & 0.12 & 45.4 \\
\hline Silicon & 2,690 & 0.63 & none \\
\hline Silver (EP toxic) & 500 & 0.12 & 454 \\
\hline Sodium & 2,340 & 0.54 & 4.54 \\
\hline Strontium & 102 & 0.024 & none \\
\hline Sulfate $\left(\mathrm{SO}_{4}\right)$ & 10,800 & 2.52 & none \\
\hline Uranium & 0.621 & 0.0001 & 45.5 \\
\hline Zinc & 29 & 0.0068 & 454 \\
\hline $\begin{array}{l}\text { 2-Butanone or } \\
\text { methylethyl ketone }\end{array}$ & 18 & 0.0042 & 2,270 \\
\hline Dichloromethane & 170 & 0.040 & none \\
\hline Phenol & 35 & 0.0082 & 454 \\
\hline Tetra-hydrofuran & 17 & 0.0040 & 454 \\
\hline
\end{tabular}


If the solution is dilute, it can be assumed that the specific gravity of the solution is 1 . If this is assumed, a concentration of $1 \mathrm{~g} / \mathrm{L}$ is equal to $1,000,000 \mathrm{ppb}$.

4.2.1.4 Used Cooling Water. Table 8-4 in Section 8.1.4 contains the data used to calculate the radionuclide source terms for the used cooling water waste stream.

Table 4-9 contains the maximum values tabulated in Section 8.1.4.

Column 4 contains the maximum potential curies that might be released during a day. This was calculated by taking the maximum recorded total yearly flow for the year of $6.34 \times 10^{+09} \mathrm{~L}$ from Table 8-4. This figure divided by $365 \mathrm{~d} / \mathrm{y}$ gives a daily flow rate of $17,369,863 \mathrm{~L} / \mathrm{d}$.

The following information is provided to help the reader understand the units used in the tables that follow.

- $C_{j}$ is an abbreviation for curie, the unit used for measuring radioactivity

- $A \mu C i$ is $1 / 1,000,000$ of a curie

- A mL is $1 / 1,000$ of a liter.

Table 4-9. Cooling Water Radionuclide Source Term.

\begin{tabular}{|l|r|r|r|}
\hline \multicolumn{1}{|c|}{$\begin{array}{c}\text { Effluent } \\
\text { Alpha }\end{array}$} & $\begin{array}{c}\text { (2) Maximum } \\
\text { from } \\
\text { Table } 8-4 \\
(\mu \mathrm{Ci} / \mathrm{mL})\end{array}$ & $\begin{array}{c}\text { WHC-EP-0342 } \\
(\mu \mathrm{Ci} / \mathrm{mL})\end{array}$ & $\begin{array}{c}\text { (4) } \\
\text { Maximum } \\
\text { potential 24-h } \\
\text { release } \\
(\mathrm{Ci})\end{array}$ \\
\hline Beta & $6.9 \mathrm{E}-09$ & $1.59 \mathrm{E}-09$ & \\
\hline${ }^{3 \mathrm{H}}$ & $9.4 \mathrm{E}-08$ & $3.19 \mathrm{E}-08$ & 0.8685 \\
\hline${ }^{137} \mathrm{Cs}$ & $5 \mathrm{E}-05$ & & 0.0010 \\
\hline${ }^{239,240 \mathrm{Pu}}$ & $6 \mathrm{E}-08$ & & 0.0003 \\
\hline${ }^{89,90 \mathrm{Sr}}$ & $1.7 \mathrm{E}-08$ & & 0.0003 \\
\hline
\end{tabular}

Table 4-10 contains the nonradionuclide data for the used cooling water waste stream. The data in this table were obtained from WHC-EP-0342, Addendum 21, 242-A Evaporator Cooling Water Stream-Specific Report (WHC 1990b).

From Table 8-4, the maximum recorded total yearly flow was $6.34 \times 10^{+09} \mathrm{~L}$. This figure divided by $365 \mathrm{~d} / \mathrm{y}$ gives a daily flow rate of $17,369,863 \mathrm{~L} / \mathrm{d}$. This figure was used to determine if the CERCLA RQ values are exceeded. 
WHC-EP-0466-1

Table 4-10. Cooling Water Nonradionuclide Source Term.

\begin{tabular}{|l|r|r|r|}
\hline \multicolumn{1}{|c|}{ Chemical } & $\begin{array}{c}\text { Concentration } \\
(\mathrm{ppb})\end{array}$ & \multicolumn{1}{c|}{$\begin{array}{c}\text { Daily release } \\
\text { rate } \\
(\mathrm{kg})\end{array}$} & $\begin{array}{c}\text { CERCLA } \\
\text { reportable } \\
\text { quant } \\
(\mathrm{kg})\end{array}$ \\
\hline Barium & 32 & 0.558 & 454 \\
\hline Calcium & 21,200 & 368.24 & none \\
\hline Cadmium & 1,070 & 0.35 & 4.54 \\
\hline Chloride (C1-) & 12 & 18.6 & none \\
\hline Chromium & 97 & 0.21 & 2,270 \\
\hline Copper & 194 & 1.68 & 2,270 \\
\hline Iron & 15.8 & 3.37 & none \\
\hline Lead & 4,860 & 0.27 & 0.454 \\
\hline Magnesium & 20 & 84.42 & none \\
\hline Manganese & 16 & 0.35 & none \\
\hline Nickel & 3,620 & 0.28 & 0.454 \\
\hline Nitrate $\left(\mathrm{NO}_{3}-\right)$ & 840 & 62.88 & none \\
\hline Potassium & 2,680 & 14.59 & none \\
\hline Sodium & 11,500 & $196.55 *$ & 4.54 \\
\hline Sulfate $\left(\mathrm{SO}_{4}\right)$ & 0.767 & 0.0133 & none \\
\hline Uranium & 67 & 1.16 & 45.4 \\
\hline Zinc & 11 & 0.19 & 454 \\
\hline 1-Butanol & 170 & 2.95 & 2270 \\
\hline Dichloromethane & none \\
\hline
\end{tabular}

*Indicates constituent is over the CERCLA RQ value. See raw-water data in Table 4-11.

CERCLA = Comprehensive Environmental Response, Compensation and Liability Act of 1980. 
The following information is provided to help the reader understand the units used in Table 4-10.

- "g" is the abbreviation for gram.

- "kg" is the abbreviation for kilogram and is equal to 1,000 grams.

- "L" is the abbreviation for liter.

- "mL" is the abbreviation for milliliter. 1,000 milliliters are equivalent to 1 liter.

- "ppb" is the abbreviation for parts per billion.

If the solution is dilute, it can be assumed that the specific gravity of the solution is 1 . If this is assumed, a concentration of $1 \mathrm{~g} / \mathrm{L}$ is equal to $1,000,000 \mathrm{ppb}$.

4.2.1.5 Raw Water. Table 4-11 contains the nonradionuclide data for the raw water. The data in this table were obtained from WHC-EP-0342, Addendum 21, 242-A Evaporator Cooling Water Stream-Specific Report (WHC 1990).

From Table 8-4, the maximum recorded total yearly flow was $6.34 \times 10^{+09} \mathrm{~L}$. This figure divided by $365 \mathrm{~d} / \mathrm{y}$ gives a daily flow rate of $17,369,863 \mathrm{~L} / \mathrm{d}$. This figure was used to determine whether the CERCLA RQ values are exceeded.

4.2.1.6 Cooling Water/Raw Water Nonradionuclide Comparison. Raw water is supplied for the cooling water at the 242-A Evaporator. Tables 4-10 and 4-11 list the nonradionuclide source terms for the used cooling water and the raw water respectively. of these constituents, and because of the quantity of water used, only sodium could possibly be reportable under CERCLA. For comparison, these values are repeated in Table 4-12. Because the sodium. in the used cooling water is in similar quantities to that in the raw water, it is reasonable to assume that no further addition of this regulated constituent was or is added during the evaporator process. It can, therefore, be concluded that these discharges are not regulated as RQs under CERCLA.

\subsubsection{Upset Operating Conditions}

This section is intended to present any additional hazardous or radioactive material releases to the environment that might occur during upset conditions. For purposes of this discussion, upset conditions are defined as any breach of a single (one) barrier.

A thorough examination of the 242-A Evaporator Facility Safety Analysis Report (WHC 1988a) was conducted to identifying upset conditions. Only one such condition meeting the criterion definition of breach of a single barrier was noted. The following is a discussion of this. 
Table 4-11. Raw Water Nonradionuclide Source Term.

\begin{tabular}{|l|r|r|r|}
\hline \multicolumn{1}{|c|}{ Chemical } & $\begin{array}{c}\text { Concentration } \\
(\mathrm{ppb})\end{array}$ & $\begin{array}{c}\text { Daily release } \\
\text { rate } \\
(\mathrm{kg})\end{array}$ & $\begin{array}{c}\text { CERCLA } \\
\text { reportable } \\
\text { quantity } \\
(\mathrm{kg})\end{array}$ \\
\hline Barium & 18,400 & 0.49 & 454 \\
\hline Calcium & 2.4 & 0.042 & none \\
\hline Cadmium & 871 & 15.12 & none \\
\hline Chloride $(\mathrm{Cl}-)$ & 10.6 & 0.18 & 2,270 \\
\hline Copper & 63.6 & 1.10 & none \\
\hline Iron & 4,190 & 72.78 & none \\
\hline Magnesium & 9.8 & 0.017 & none \\
\hline Manganese & 10.4 & 0.18 & 0.454 \\
\hline Nickel & 996 & 17.3 & none \\
\hline Nitrate $\left(\mathrm{NO}_{3}-\right)$ & 795 & 13.81 & none \\
\hline Potassium & 2,260 & $39.26 *$ & 4.54 \\
\hline Sodium & 10,600 & 184.12 & none \\
\hline Sulfate $\left(\mathrm{SO}_{4}\right)$ & 0.726 & 0.013 & 45.4 \\
\hline Uranium & 20 & 0.35 & 454 \\
\hline Zinc & 11.8 & 0.21 & 2,270 \\
\hline Trichloromethane & $8.85 \mathrm{E}-10$ & $\mathrm{NA}$ & $\mathrm{NA}$ \\
\hline Alpha $(\mu \mathrm{Ci} / \mathrm{mL})$ & $4.47 \mathrm{E}-09$ & $\mathrm{NA}$ & $\mathrm{NA}$ \\
\hline Beta $(\mu \mathrm{Ci} / \mathrm{mL})$ & & & \\
\hline
\end{tabular}

*Indicates constituent is over the CERCLA RQ value. See discussion in Section 4.2.1.6. 
Table 4-12. Raw Water/Cooling Water CERCLA RQ Comparison.

\begin{tabular}{|c|c|c|}
\hline Constituent & $\begin{array}{c}\text { 24-h Raw-water } \\
\text { quantity supplied } \\
(\mathrm{kg})\end{array}$ & $\begin{array}{c}24-\mathrm{h} \text { Cooling water } \\
\text { quantity released } \\
(\mathrm{kg})\end{array}$ \\
\hline Sodium & 39.26 & 46.55 \\
\hline
\end{tabular}

Scenario: Excessive ammonia concentrations--The presence of ammonia $\left(\mathrm{NH}_{3}\right)$ in evaporator feed stems from $N$ Reactor fuel dissolution operations at PUREX. To dissolve the zircalloy fuel claddig a boiling solution of ammonium fluoride and ammonium nitrate is used. The liquid waste that results is neutralized with sodium hydroxide solution and sent to tanks TK-103-AW or TK-105-AW in the AW Tank Farm for eventual routing to the 242-A Evaporator. This waste, referred to as neutralized cladding removal waste (NCRW), contains approximately $30 \%$ of the ammonium ions charged to the dissolvers.

Approximately $70 \%$ of the ammonium ions charged to PUREX dissolvers is converted to ammonia gas and is either adsorbed in the dissolver condensate or scrubbed from the dissolver offgas. Past practice has been to transfer all dissolver condensate and scrub liquid, collectively referred to as ASF, to a small evaporator within the PUREX PIant. The bottoms from this evaporator, containing concentrated radionuclides, were sent to Tank Farms; the overheads, containing essentially all of the ammonia present in ASF, were condensed and sent to a crib while noncondensables were released out the stack.

Environmental regulations limit the quantities of ammonia that may be discharged to the atmosphere to $45.5 \mathrm{~kg} / 24 \mathrm{~h}(100 \mathrm{lb} / 24 \mathrm{~h})$, and the concentration and quantities of ammonium hydroxide permissible in liquid effluent streams are 1 imited to $1 \mathrm{wt} \%$ or $454.5 \mathrm{~kg} / 24 \mathrm{~h}(1,0001 \mathrm{~b} / 24 \mathrm{~h})$. Consequently, ASF is no longer processed at the PUREX Plant. Instead, as an interim step towards regulatory compliance, ASF is sent to Tank TK-103-AP in the AP Tank Farm for eventual routing to the 242-A Evaporator. Methods for destroying the ammonia content of both NCRW and ASF within PUREX Plant (such as reacting acidified ASF with sodium nitrite) are being investigated.

To ensure that 1 iquid and gaseous effluents from the 242-A Evaporator do not exceed the ammonia and ammonium hydroxide discharge limits, NCRW $(0.1$ to $0.5 \mathrm{M})$ and $\mathrm{ASF}(0.2$ to $0.4 \mathrm{M})$ are blended with nonammonia-bearing waste in Tank TK-102-AW to produce an evaporator feed stream with a $10 \mathrm{~W} \mathrm{NH}_{3}$ concentration $(0.08 \mathrm{M})$. Blending protocols are established by process engineering based on ammonia content of the waste to be blended. Before pumping the blended feed to the evaporator, Tank TK-102-AW is sampled and analyzed to verify an acceptable $\mathrm{NH}_{3}$ concentration.

The accident scenario is postulated in which an error in blending NCRW with nonammonia-bearing waste leads to a higher than expected ammonia concentration in Tank TK-102-AW. The NCRW was selected for 
analysis over ASF because it typically has a higher ammonia content.

A failure to detect or correct the blending error is assumed to occur so that the contents of Tank TK-102-AW are fed to the evaporator resulting in elevated ammonia releases. A failure of routine sampling to detect this error at an early stage allows the release to continue for several hours.

Source Term--The ammonia concentration in NCRW ranges typically from 0.1 to $0.5 \mathrm{M}$. Given an error in blending, it is estimated that a concentration of $0.4 \mathrm{M}$ could be achieved in Tank TK-102-AW. This estimate is based on the assumption that $0.5 \mathrm{M}$ NCRW is mistakenty blended as if it were $0.1 \mathrm{M}$.

A validated model for estimating ammonia release as a function of the feed concentration and other critical parameters (e.g., feed rate, operating pressures and temperatures, condenser efficiencies) does not exist. Estimates can be made, based on sampling data from previous evaporator operations.

Given nominal feed and boiloff rates 302.8 and $151.4 \mathrm{~L} / \mathrm{min}$ ( 80 and $40 \mathrm{gal} / \mathrm{min}$, respectively), a $0.4 \mathrm{M}$ feed concentration, and conservatively assuming that all of the ammonia in the feed is converted to ammonia gas in the evaporator (as opposed to an expected $90 \%$ ), the estimated ammonia concentration released out the vessel vent stack is $2,500 \mathrm{ppm}[57.3 \mathrm{~kg} / 24 \mathrm{~h}(126 \mathrm{lb} / 24 \mathrm{~h})]$. This value is believed to be conservative in that it was linearly extrapolated from low-feed concentration ( $0.04 \mathrm{M})$ data. Computer modeling has shown that a linear relationship does not exist and that a higher ammonia feed stream will have a smaller percentage of the ammonia go with the vessel vent offgas.

In the past, ammonia releases from the 242-A Evaporator were measured at the vessel vent stack using ammonia detector tubes and an ammonia gas absorption apparatus. A continuous ammonia monitor is scheduled for installation for use in future operations.

Detector tubes were inserted periodically into the vessel vent airflow to provide an instantaneous measure of the ammonia concentration. Although only accurate to $\pm 30 \%$, the detector tube results are adequate for process control needs.

The gas absorption sampling apparatus collected ari ammonia sample by bubbling a portion of the vessel vent airflow through a boric acid solution. This solution is titrated to quantitatively determine the ammonia content. This method is accurate to $\pm 10 \%$, and the result, available in approximately $4 \mathrm{~h}$, is used to document regulatory compliance.

Sampling for ammonia was performed at the process condensate retention basins using both ammonia detector tubes and an ammonia gas absorption apparatus that could be positioned over any portion of a basin. 


\subsection{EFFLUENT POINT OF DISCHARGE DESCRIPTION}

The purpose of this chapter is to identify, describe, and characterize all effluent discharge points (actual and potential) for the facility. In addition, the locations of monitoring/sampling points are identified.

Effluent discharge points are the final point where effluents are monitored, sampled, diverted, otherwise controlled, or where the stream exits the facility into the environment.

\subsection{GASEOUS EFFLUENT STREAMS}

As previously described in Section 4.1.1, the two major airborne effluent release points for the 242-A Evaporator facility are the 296-A-22 stack (vessel ventilation system) and the 296-A-21 stack ("hot area" building ventilation system). A third separate air system supplies the noncontaminated (cold) area and exhausts through miscellaneous dampers and vents. Table 5-1 lists these major and minor gaseous effluent streams.

Table 5-1. 242-A Evaporator/Crystallizer Gaseous Effluent Streams.

\begin{tabular}{|l|l|c|}
\hline \multicolumn{1}{|c|}{ Stream } & \multicolumn{1}{|c|}{ Function } & EDP Code \\
\hline 296-A-22 Stack & Filtered exhaust air vessel vent system & E643 \\
\hline 296-A-21 Stack & Building containment exhaust system & E645 \\
\hline K2-5-2 Fan & Aqueous makeup unit room exhaust & N/A \\
\hline K2-5-3 Fan & "Cold" area roof exhaust & N/A \\
\hline MK-9863 Damper & Control room air exit & N/A \\
\hline MK-9861 Damper & Office barometric relief damper & N/A \\
\hline
\end{tabular}

NOTE: $E D P=$ electronic data processing.

\subsubsection{Vessel Ventilation System}

The vessel ventilation system is located in the southeast corner of the condenser room and extends in elevation from $220 \mathrm{~m}(722 \mathrm{ft}, 6 \mathrm{in}$.$) , to the$ stack exhaust point at $230 \mathrm{~m}$ ( $753 \mathrm{ft}, 6 \mathrm{in.})$. The system consists of a deentrainment unit (DU-C-1), prefilter/demister $(F-C-6)$, heater $(H-C-1)$, HEPA filter assemblies $(F-C-5-1$ and $F-C-5-2)$, an exhauster $(E X-C-1)$, and a stack monitoring system.

Noncondensed vapors from the vacuum condenser and process condensate systems are filtered and discharged to the atmosphere via the vessel vent system. Also, the after condenser drain and the condensate collection tank $($ TK-C-100) are vented to the atmosphere through this system. An air intake 
filter ( $F-C-7)$ is used to bleed building air into the vessel vent system to maintain proper ventilation balance and prevent deadheading of the vessel vent exhauster.

The deentrainment unit and prefilter each measure $41.9 \mathrm{~cm}$ by $36.8 \mathrm{~cm}$ by $17.8 \mathrm{~cm}$ (16.5 in. by $14.5 \mathrm{in}$. by $7 \mathrm{in.}$ ) and are designed to remove large particulates and moisture that may damage or reduce the efficiency of the HEPA filters. Raw water is supplied to the deentrainment unit. The deentrainment pad is provided with a lower raw-water spray as well as an upper spray nozzle.

The vessel vent system has an electric heating unit designed to maintain a minimum $38{ }^{\circ} \mathrm{C}\left(50^{\circ} \mathrm{F}\right)$ temperature differential across its coil. The heater ensures that the ventilation stream humidity is acceptable and that vapors do not condense on and damage the downstream HEPA filters. A temperatureindicating controller senses the entering and exiting stream temperatures and controls the heater to add heat as necessary to maintain the desired temperature differential. A temperature safety switch shuts off the ventilation heater when the temperature exceeds $93{ }^{\circ} \mathrm{C}\left(200^{\circ} \mathrm{F}\right)$. In addition, a high temperature alarm is interlocked to shut off the vessel ventilation heater. The vessel ventilation heater is also interlocked to shut off if the exhaust fan shuts down.

The two in-series HEPA filters are used to filter noncondensed vapors from the evaporator, vacuum condenser, and process condensate systems. These units have replaceable cartridges that measure $61.0 \mathrm{~cm}$ by $61.0 \mathrm{~cm}$ by $29.2 \mathrm{~cm}$ (24 in. by 24 in. by 11.5 in.). Each filter has an efficiency greater than $99.95 \%$ for particles $0.3 \mu \mathrm{m}$ in diameter or 1arger. Differential pressure across the HEPA filters is continuously monitored. High or low differential pressure is alarmed and interlocked to shut down the process system.

5.1.1.1 Vessel Ventilation Stack. The 296-A-22 vessel vent stack is associated with the 242-A Evaporator Crystallizer facility and has been given the Hanford Site electronic data processing (EDP) Code E643.

The 296-A-22 vessel vent stack is a cylindrical vertical stack. The stack begins on the third floor of the condenser room above the exhauster fan. This floor is $9.3 \mathrm{~m} \mathrm{(30} \mathrm{ft,} 6 \mathrm{in.}$ ) above ground level, which is $210.9 \mathrm{~m}$ $(692 \mathrm{ft})$ above sea level. At $0.96 \mathrm{~m}(375 / 8 \mathrm{in.})$ above the floor, the stack flares out to an inside diameter of $20.3 \mathrm{~cm}(8 \mathrm{in.})$. At $5.38 \mathrm{~m}$ (17 ft, $8 \mathrm{in.})$ above the floor, the stack makes a 90 degree turn to horizontal and penetrates through the exterior wall of the building. Once outside, it makes another 90 degree turn back to vertical and terminates at an elevation of $18.75 \mathrm{~m}$ $(61 \mathrm{ft}, 6 \mathrm{in.})$ above ground level.

5.1.1.2 Vessel Ventilation Stack Flow. Vessel ventilation gases are exhausted through the 296-A-22 stack. The vessel ventilation exhauster nominally delivers $19.82 \mathrm{~m}^{3} / \mathrm{min}\left(700 \mathrm{ft}^{3} / \mathrm{min}\right)$ at $25.4 \mathrm{~cm}(10 \mathrm{in}$.) of water gage. An induction electric motor, which operates on 3-phase, $460 \mathrm{~V}$ electric power and develops $2.2 \mathrm{~kW}(3 \mathrm{hp})$ of power, drives the exhauster. The vessel vent exhauster fan $(E X-C-1)$ can be operated remotely by selector switch 
HS-EXC-3 and locally by hand switches HS-EXC-1 and HS-EXC-2. The exhaust fan is interlocked to shut down automatically should the following occur:

- High radiation is detected in the vessel vent stack

- High differential pressure is detected at the vessel vent filters

Stack flow rates are measured quarterly using Hanford Maintenance Procedure 7-GN-56, Airflow Capacity and Distribution Tests (WHC 1989a). Stack flow measurement logs are maintained by the Vent and Balance group and reviewed to demonstrate that flow rates are within variance ranges that do not require stack flow totalizing. The following information, obtained from stack flow rate measurement data, demonstrates the flow rate within the vessel vent stack.

- The average of 115 stack flow measurements taken between September 1987 and January 1991 was computed to be $723 \mathrm{ft}^{3} / \mathrm{min}$.

- The maximum of these 115 measurements was $829 \mathrm{ft}^{3} / \mathrm{min}$.

- The minimum of these 115 measurements was $598 \mathrm{ft}^{3} / \mathrm{min}$.

The following are the total volumetric flow rates through the 296-A-22 stack for 1988 and 1989 [reference WHC-EP-0141-1, Westinghouse Hanford Company Effluent Discharges and Solid Waste Management Report for 1988: 200/600 Areas (WHC 1989e), and WHC-EP-0141-2, Westinghouse Hanford Company Effluent Discharges and Solid Waste Management Report for 1989: 200/600 Areas (WHC 1990a)].

\begin{tabular}{|c|c|}
\hline Year & Volume (L) \\
\hline 1988 & $2.59 \mathrm{E}+11$ \\
\hline 1989 & $4.81 \mathrm{E}+09$ \\
\hline
\end{tabular}

The location chosen for flow measurements on the vessel vent stack varies depending on which port is accessible at the time. Two ports are known to have been used in the past. One port is located on the third floor of the condenser room approximately $7 \mathrm{ft}$ off the floor. The other port known to have been used is on the fourth floor of the condenser room. This is about $1 \mathrm{ft}$ above the sample probe location within the stack and about $4 \mathrm{ft}$ below the elbow in the stack, which directs the flow outside the building (see stack description in Section 5.1.1.1).

The appropriateness of these locations has been analyzed and is discussed in Section 14.1.1.1.

5.1.1.3 Vessel Ventilation Stack Monitoring/Sampling. Vessel ventilation gases are exhausted through the 296-A-22 stack. The vessel vent exhaust air is continuously sampled and monitored for radioactive materials. Samples are 
drawn from the stack using a near isokinetic sampling system (a perfect isokinetic system would draw the sample from the stream at exactly the same velocity as the stream).

The sampling point is on the stack at $3.96 \mathrm{~m}(13 \mathrm{ft})$ above the third level of the condenser room. The appropriateness of this location has been analyzed and is discussed in Section 14.1.1.2.

A sampler probe draws air from the vessel vent stack at a flow rate of $6.2 \mathrm{std} \mathrm{ft}^{3} / \mathrm{min}$. The sampler probe incorporates the use of two nozzles for sampling the stack flow [refer to drawing H-2-69316 (AEC 1977)]. The appropriateness of the existing sample extraction systems has been analyzed and is discussed in Section 14.1.1.3.

A sample transport line extends from the probe connection flange to the monitoring instruments located on shelves near the stack. The sample transport line is heat traced [operating at $43{ }^{\circ} \mathrm{C}\left(110^{\circ} \mathrm{F}\right)$ ] to inhibit condensation of moisture and resultant sample flow retardation by maintaining the temperature above the dew point. The sample transport line was selected and installed in a manner designed to minimize particle loss attributed to gravity settling, turbulent impaction, and electrostatic effects. The run lengths, bend radii, and tube transition severity of the sample transport line are minimized to the extent practical.

The sample air flows into the vessel vent radiation monitoring system instrumentation rack. The monitoring rack is located adjacent to the stack in the southeast corner of the third level of the condenser room. The sample stream passes through a flow splitter and is divided into two parts:

1. One part passes through a record sample filter. The record sampler collects effluent particulates on a 47-mm-diameter filter (millipore SM or equivalent). The record sample filter is exchanged weekly and evaluated for gross alpha and gross beta activities and for specific radionuclides by laboratory analyses. The record sampler provides an indication of the amount and concentrations of radioactive particulates being discharged. The record samples provide the bas is for reporting the amount and concentration of radionuclides released to the environment. These reports are forwarded to all appropriate organizations and agencies.

From there, the record sample loop passes through two silver zeolite cartridge filters. These filters collect volatile radionuclides. Silver zeolite filters are designed to collect ${ }^{129} \mathrm{I},{ }^{131} \mathrm{I},{ }^{125} \mathrm{Sb}$, ${ }^{113} \mathrm{Sn},{ }^{103} \mathrm{Ru}$, and ${ }^{106} \mathrm{Ru}$. The cartridge filters are exchanged and sent to the laboratory weekly.

Downstream of the filters, the record sample loop passes in turn through a flowmeter, a flow integrator indicator (totalizer), a pressure indicator, a flow regulator, and a vacuum return pump. The record sampling system has sample flow-rate indicating (local and remote) and totalizing $\left(\mathrm{m}^{3} \pm 10 \%\right)$ capabilities. The flow-rate regulator is provided for daily adjustment to maintain a flow rate of 2.2 std $\mathrm{ft}^{3} / \mathrm{min}( \pm 10 \%)$ through the collection filter assembly to compensate for filter loading effects. Audible and visible alarm 
signals indicating low sample flow ( $\leq 1.25 \mathrm{ft}^{3} / \mathrm{min}$ ) are provided locally (bell and beacon) and remotely on the Monitor and control System (MCS) in the 242-A Control Room. The record sample flow rate is sized to provide optimum samples for laboratory analyses.

2. The second part of the sample stream is divided into two more streams by another flow splitter.

One portion passes through a beta/gamma CAM* equipped with remote (control room) and local alarms. The CAM (RM-VV-2) continuousiy monitors particulate matter buildup on a 47-mm-diameter filter paper (millipore SM or equivalent) for the detection and measurement of beta and gamma radiation. The filter paper is exchanged weekly and analyzed in the field for gross beta and gamma concentrations. This information is logged by Health Physics personnel.

The second portion passes through an alpha CAM that is similar to the beta/gamma CAM. It is equipped with remote (control room) and local alarms. This CAM (RM-VV-1) continuously monitors for alpha radionuclide buildup on 47-mm-diameter sample filter papers. Filter papers are exchanged weekly and analyzed in the field for gross alpha concentration. This information is logged by Health Physics personne1.

The CAM loops (beta/gamma and alpha) within the 296-A-22 stack EMS have flow-rate-indicating and regulating capabilities. A flow-rate regulator is provided on each loop for daily adjustment to maintain a flow rate of $2.0 \mathrm{std} \mathrm{ft}^{3} / \mathrm{min}( \pm 10 \%)$ through the collection filter assembly to compensate for filter loading effects. The CAM systems have local readout count-rate meters and remote strip chart recording capability in the control room. Audible and visible alarms, including high airborne radiation, instrument malfunction, and low sample flow indications $\left(\leq 1.25 \mathrm{ft}^{3} / \mathrm{min}\right)$, are provided locally and on the MCS in the 242-A Control Room. In addition, high-stack radiation and high-stack alpha radiation alarms are annunciated on the Computer Automated Surveillance System (CASS). An exhaust alpha monitor failure alarm is also tied to the CASS. An elapsed time meter is interlocked with stack blower-fan operation to provide a measure of exhaust stack operation time. The record sample vacuum pump is ganged to exhaust fan operation via a switched receptacle in the system cabinet. The CAM vacuum pumps operate continuously via the unswitched receptacle in the cabinet.

Independent vacuum pumps are provided for each loop of the system. Redundant vacuum systems are not furnished, but failure annunciation (low flow rates) is provided and checked periodically to demonstrate operability.

* Continuous Air Monitors serve as warning devices to alert personnel to releases that exceed normal operating parameters. The CAMs collect particulates on a filter monitored continuously by a radiation detector. The CAM filter may be used as a backup for the record sample. 
Each loop of the sample stream, after passing through its particular sampler/monitor and flow control systems, is pumped by individual vacuum pump through a line that discharges back into the vessel vent stack at a point approximately $2 \mathrm{ft}$ below the sampler probe position.

High $\mathrm{NH}_{3}$ concentrations in certain feeds have increased the potential for releases of ammonia gas from the vessel vent stack. In the past, ammonia releases from the vessel vent stack were measured by ammonia detector tubes (Drager tubes) and an ammonia gas absorption apparatus (bubbler sampling). The methods used were based on those required by the Clean Air Act of 1977.

The Drager tube samples are taken from a port in the vessel vent stack located on the fourth level of the condenser room approximately $1 \mathrm{ft}$ above the sampler probe position on the stack. The detector tubes are inserted manually into the vessel vent airflow and provide an instantaneous measurement of the ammonia concentration. Although only accurate to $\pm 30 \%$, the results provide a timely basis for process control.

The frequency of ammonia sampling varies depending on the phase of the process operation. During initial startup, ammonia sampling is performed hourly until acceptable ammonia releases are confirmed. Then, the sampling frequency is reduced. Sampling frequencies will be determined during the initial run following completion of upgrade modifications.

Installation of an automatic real-time ammonia monitoring system to be located in the stack next to the radiation monitoring port is part of the current evaporator upgrade. With this continuous ammonia monitor installed, the gas absorption apparatus has been removed because it will not be used in the future. With the new system, the $\mathrm{NH}_{3}$ concentration of the gaseous sample shall be monitored continuously with an infrared analyzer. Alarms shall be adjustable and have normally opened/normally closed (NO/NC) relay contacts. The system will be enclosed within a weather resistant, temperature controlled and ventilated enclosure that includes a red beacon for visual alarm. The system will not be adversely affected by extended operation in ambient temperatures between $-28.9{ }^{\circ} \mathrm{C}$ and $43.3{ }^{\circ} \mathrm{C}\left(-20^{\circ} \mathrm{F}\right.$ and $\left.110{ }^{\circ} \mathrm{F}\right)$ and ambient humidities of less than $90 \%$.

This system shall have the following capabilities:

- Extraction of exhaust stack air stream samples using stainless steel sample probes

- Determination of ammonia concentration with an accuracy and repeatability within $\pm 10 \mathrm{ppm}$ for $\mathrm{NH}_{3}$ concentrations between 0 and $1,000 \mathrm{ppm}$ and within $\pm 50 \mathrm{ppm}$ for $\mathrm{NH}_{3}$ concentrations between 1,000 and $5,000 \mathrm{ppm}$

- Automatic calibration at specified intervals using calibration gas blends of certified ammonia concentration ( $\pm 2 \mathrm{ppm})$.

An organic monitoring system will be used for future campaigns to verify compliance of organic emissions within regulatory limits by periodic sampling. The monitoring system is designed to meet the requirements of EPA standard method 0030, Volatile Organic Sampling Train, (EPA, 1986) (reference: SW-846, 
Laboratory Manual, Vol 2: Test Methods for Evaluating Solid Waste Physical/Chemical Methods). This system uses Tenex ${ }^{0 *}$ cartridges to capture organic emissions for future analysis. The Tenex cartridges will be analyzed for the organic hazardous analytes listed in Table 5-2. These chemicals were chosen because they represented the largest potential emissions at the time.

\subsubsection{Vessel Vent Sampling/Monitoring Environmental Conditions. The} sampling and monitoring instrumentation for the vessel ventilation system is subjected to the environmental conditions in the condenser room and the control room of the facility. Typical temperatures within the condenser room are $26.7 \pm 5.6{ }^{\circ} \mathrm{C}\left(80^{\circ} \mathrm{F} \pm 10^{\circ} \mathrm{F}\right)$. The design operating temperature range in the condenser room is from $23.9^{\circ} \mathrm{C}\left(75^{\circ} \mathrm{F}\right)$ to $32.2{ }^{\circ} \mathrm{C}\left(90^{\circ} \mathrm{F}\right)$. The control room is temperature and humidity controlled with a separate ventilation system.

\subsubsection{Building Ventilation System}

The hot/contaminated areas of the building are discharged to the atmosphere through the 296-A-21 Building ventilation stack. The hot area is supplied with approximately $8.73 \times 10^{6} \mathrm{~cm}^{3} / \mathrm{s}\left(18,500 \mathrm{ft}^{3} / \mathrm{min}\right)$ of outside air from an intake fan $(\mathrm{Kl}-5-1)$ and approximately $3.78 \times 10^{5} \mathrm{~cm}^{3} / \mathrm{s}\left(800 \mathrm{ft}^{3} / \mathrm{min}\right)$ of air in-leakage from the loading room. Air from the intake fan passes through a preheat coil $(K 1-2-1)$ and dust filters (K1-7-1 and K1-11-1). $4.25 \times 10^{5} \mathrm{~cm}^{3} / \mathrm{s}\left(900 \mathrm{ft}^{3} / \mathrm{min}\right)$ of the intake air passes through an air washer $(K 1-3-1)$, and two reheat coils (K1-4-1 and $K 1-1-7)$ before entering the loading room. $4.58 \times 10^{6} \mathrm{~cm}^{3} / \mathrm{s}\left(9700 \mathrm{ft}^{3} / \mathrm{min}\right)$ of the intake air passes through the air washer $\left(K_{1}-3-1\right)$ and reheat coil $\mathrm{K}_{1-4-2}$ before entering the condenser room. $3.07 \times 10^{6} \mathrm{~cm}^{3} / \mathrm{s}\left(6500 \mathrm{ft}^{3} / \mathrm{min}\right)$ of the intake air passes through reheat coils K1-4-3 and K1-4-5 before entering the evaporator room. $6.61 \times 10^{5} \mathrm{~cm}^{3} / \mathrm{s}$ $\left(1400 \mathrm{ft}^{3} / \mathrm{min}\right)$ of the intake air passes through reheat coils $\mathrm{K} 1-4-4$ and $\mathrm{K} 1-4-6$ before entering the pump room.

All air is discharged into a main line, which splits into two parallel filter trains before it is discharged to the atmosphere via the 296-A-21 stack. Each train consists of one [870 National Bureau of standards (NBS)] dust filter (K1-15-1 or K1-15-2) and two HEPA filters (K1-6-1 and $K 1-6-3$ or $K 1-6-2$ and $K 1-6-4$ ) in series. The HEPA filters have a minimum efficiency of $99.97 \%$ as tested individually at the Hanford Environmental Health Foundation (HEHF). The efficiency of the installed filters is required to be $99.95 \%$ for particles $0.3 \mu \mathrm{m}$ or larger. The differential pressures (DP) across both the first and second HEPA filters are monitored. A low DP across either the first or second filters could indicate a failure resulting from loss of all or part of the filter media, while a high DP across the first filter would indicate filter pluggage with a potential for filter failure. Each condition is annunciated in the control room.

The air exits through a $9.1 \times 10^{6}-\mathrm{cm}^{3} / \mathrm{s}-\left(19,300-\mathrm{ft}^{3} / \mathrm{min}-\right)$ capacity electric exhaust fan (K1-5-3) into the 242-A-21 stack. A steam turbine-driven fan (K1-5-2) of identical capacity is available as a backup. Failure of the electric exhaust fan to maintain a specific flow will initiate the shutdown of the electric fan and startup of the steam turbine-driven fan.

*Tenex is a trademark of Burdick and Jackson. 
Table 5-2. 242-A Evaporator Vessel Ventilation Hazardous Analytes.

\begin{tabular}{|l|l|}
\hline \multicolumn{1}{|c|}{ inorganic analytes } & $\mathrm{NH}_{3}$, ammonia \\
\hline \multirow{5}{*}{ Volatile organic analytes } & Acetone \\
\cline { 2 - 2 } & Methyl ethyl ketone \\
\cline { 2 - 2 } & Methylene chlorice \\
\cline { 2 - 2 } & Methyl isobutyl ketone \\
\hline & N-butyl alcohol \\
\hline & $1,1,1$ Trichlorethane \\
\cline { 2 - 2 } & Carbon tetrachloride \\
\hline
\end{tabular}

The hot area is maintained at a negative pressure so that air enters the potentially contaminated areas rather than exits to the progressively cleaner areas of the building. In addition, individual room air pressures are maintained such that the pressure in highly contaminated rooms is less than in rooms with less potential for contamination. Negative pressure in the area is normally maintained by operating the electric exhaust fan. After the exhaust fan has been started, the intake fan starts automatically when the pressure in the pump room approaches the required negative value. The amount of supply air is limited to a preset value and is controlled by adjusting dampers in the intake ducts of the intake air system. A signal from a flow-measuring element in the intake fan duct controls the dampers. A loss of flow from the intake fan signals shutdown of the intake motor.

5.1.2.1 Building Ventilation Stack. The 296-A-21 Building exhaust stack is associated with the 242-A Evaporator Crystallizer facility and has been given the Hanford Site EDP Code E645.

The 242-A-21 Building exhaust stack is a $106.7-\mathrm{cm}-(42-$ in.) diameter, cylindrical, vertical duct located at the end of the parallel building exhaust trains on the concrete HVAC equipment pad outside the northwest corner of Building 242-A. The top of the stack is $5.8 \mathrm{~m}(22 \mathrm{ft})$ above ground level, which is $210.9 \mathrm{~m}$ (691 ft, 6 in.) above sea level.

The 242-A Evaporator Building ventilation system is equipped with room air sampling and radiation monitoring systems (refer to Section 4.1.1.2). The exhaust stack also is equipped with a radiation monitoring and sampling system. A high radiation reading in the exhaust stream initiates safety interlock shutdown of both the electric and steam turbine exhaust fans, which in turn initiates shutdown of the intake fan on loss of negative pressure in the hot zones. This interlock effectively shuts down the hot area ventilation system to prevent release of air contaminants.

5.1.2.2 Building Ventilation Stack Flow. The building ventilation system has a nominal volumetric flow rate of $19,300 \mathrm{ft}^{3} / \mathrm{min}$. The following table 
contains flow measurement data and average, maximum, and minimum measured airflow through the 296-A-21 stack:

Table 5-3. 296-A-21 Stack Flow.

\begin{tabular}{|c|c|}
\hline Date & $\begin{array}{c}296-A-21 \text { Stack flow } \\
(\mathrm{ft} / \mathrm{min})\end{array}$ \\
\hline $08-22-91$ & 19,207 \\
\hline $05-22-91$ & 21,329 \\
\hline $04-16-91$ & 22,106 \\
\hline $01-07-91$ & 20,263 \\
\hline $10-02-89$ & 16,987 \\
\hline $08-15-89$ & 18,327 \\
\hline $06-28-89$ & 21,878 \\
\hline $04-17-89$ & 19,089 \\
\hline $01-16-89$ & 19,724 \\
\hline $11-10-88$ & 19,749 \\
\hline $04-21-88$ & 14,294 \\
\hline $01-07-88$ & 16,134 \\
\hline $10-28-87$ & 17,527 \\
\hline Average & 18,970 \\
\hline Maximum & 22,106 \\
\hline Minimum & 14,294 \\
\hline
\end{tabular}

A flow measuring device $(K 1-F E-2-1)$ enters the stack through a port approximately $3.66 \mathrm{~m}(12 \mathrm{ft})$ above the pad. However, this device is inoperable and is currently undergoing redesign, fabrication, and installation.

The flow measurements for this stack are taken by the Vent and Balance group using procedure 7-GN-56, Airflow Capacity and Distribution Tests (WHC 1989a). This procedure is accomplished quarterly. A standard pitot tube is used in conjunction with a micromanometer. The procedure calls for the velocity measurement to be made at least 7.5 duct diameters downstream from any airflow disturbances. The location used for building ventilation flow measurement is not on the stack. The location is approximately $61 \mathrm{~cm}(2 \mathrm{ft})$ from the fan on the duct work leading to the stack. Five measurements are taken from each of six existing ports on this duct work.

The appropriateness of this method and where the measurement is performed is evaluated and discussed in Section 14.1.2.1.

5.1.2.3 Building Ventilation Stack Monitoring/Sampling. The building ventilation exhaust stack is equipped with a radiation monitoring and sampling system. A high radiation reading in the exhaust stream initiates safety interlock shutdown of both the electric and steam turbine exhaust fans, which in turn initiates shutdown of the intake fan on loss of negative pressure in the hot zones. This interlock effectively shuts down the hot area ventilation system to prevent release of air contaminants. 
Building exhaust stack $296-\mathrm{A}-21$ is equipped with an air sampling probe placed into the stack $1.07 \mathrm{~m}$ (42 in.) below the top of the stack. The appropriateness of this location has been analyzed and is discussed in Section 14.1.2.2.

A sample stream is withdrawn from the exhaust stream through the sampler probe, which contains five nozzles. The appropriateness of the existing sample extraction systems has been analyzed and is discussed in Section 14.1.2.3.

The sample is drawn through a line that is heat traced (maintained at a temperature of $43{ }^{\circ} \mathrm{C}$ or $110^{\circ} \mathrm{F}$ ) to prevent moisture condensation within the sampler line. This line carries the sample to the sampler cabinet located on the HVAC equipment pad adjacent to the 296-A-21 stack.

Sample transport lines were selected and ir.stallea in a manner designed to minimize particle loss attributed to gravity settling, turbulent impaction, and electrostatic effects. Sample transport line runs, bends, and tube transitions are minimized to the extent practical. Sample transport line bend radii are at least 10 times the inside diameter of the transport line. Sample transport lines are supported to minimize wind-induced vibration effects.

The sampler/monitor system consists of a record sampler, alpha CAM, and a beta/gamma CAM. The flow from the sampler line is split into two separate flows. One flow loop goes through the record sampler. The other flow is again split, with one line going to the alpha CAM and the other going to the beta/gamma CAM. Each of the two CAM flow loops has its own regulated vacuum pump that draws approximately $9.44 \times 10^{2} \mathrm{~cm}^{3} / \mathrm{s}\left(2 \mathrm{ft}^{3} / \mathrm{min}\right)$ of air. The record sample loop also has a separate regulated vacuum pump that draws approximately $1.04 \times 10^{3} \mathrm{~cm}^{3} / \mathrm{s}\left(2.2 \mathrm{ft}^{3} / \mathrm{min}\right)$ of air. The total flow rate at the sampler probes is approximately $1.98 \times 10^{3} \mathrm{~cm}^{3} / \mathrm{s}\left(6.2 \mathrm{ft}^{3} / \mathrm{min}\right)$.

The record sampler collects effluent particulates on a 47-mm-diameter filter paper (millipore SM or equivalent) that is exchanged weekly and evaluated for gross alpha and gross beta activities and for specific radionuclides by laboratory analyses. The record sampler provides an indication of the amount and concentrations of radioactive particulates being discharged. The record samples provide the basis for reporting the amount and concentration of radionuclides released to the environment. Downstream of the filters, the record sample loop passes in turn through a flowmeter, a flow integrator indicator (totalizer), a pressure indicator, a flow regulator, and a vacuum return pump.

The record sampling loop has sample flow-rate indicating (10cal and remote) and totalizing $\left(\mathrm{m}^{3} \pm 10 \%\right)$ capabilities. A flow-rate regulator is provided for daily adjustment to maintain a flow rate of $2.2 \mathrm{std} \mathrm{ft}^{3} / \mathrm{min}$ $( \pm 10 \%)$ through the collection filter assembly to compensate for filter loading effects. Audible and visible alarm signals indicating low sample flow $\left[\leq 1.25 \mathrm{ft}^{3} / \mathrm{min}\left(0.035 \mathrm{~m}^{3}\right.\right.$, win) ] are provided locally (bell and beacon) and remotely (MCS in the 242-A Control Room). The record sample flow rate is sized to provide optimum samples for laboratory analyses.

The beta/gamma CAM (RM-K1-2) continuously monitors particulate matter buildup on a 47-mm-diameter filter paper (millipore SM or equivalent) for beta 
and gamma radiation. The filter paper is exchanged weekly and analyzed in the field for gross beta and gamma concentrations. This information is logged by Health Physics personnel.

The alpha CAM is similar to the beta/gamma CAM. This CAM (RM-K1-1) continuously monitors for alpha radionuclide buildup on the sample filter papers. Filter papers are exchanged weekly and analyzed in the field for gross alpha concentrations. This information is logged by Health Physics personnel.

Count-rate meters associated with each radiation monitor loop relay data to beta/gamma and alpha recorders in the corirul room.

The CAM loops (beta/gamma and alpha) have flow-rate indicating and regulating capabilities. A flow-rate regulator is provided on each loop for daily adjustment to maintain a flow rate of $2.0 \mathrm{std} \mathrm{ft}^{3} / \mathrm{min}( \pm 10 \%)$ through the collection filter assembly to compensate for filter loading effects. The CAM systems have local readout count-rate meters and remote strip chart recording capability in the control room. Audible and visible alarms, including high airborne radiation, instrument malfunction, and low sample flow indications, are provided locally and in the 242-A control room. In addition, high stack radiation and high stack alpha radiation alarms are annunciated on the CASS for both the vessel vent and building ventilation stacks. A building exhaust alpha monitor failure alarm is also tied to the CASS.

An elapsed-time meter is interlocked with stack blower fan operation to provide a measure of exhaust stack operation time. The record sample vacuum pump is ganged to exhaust fan operation via a switched receptacle in the system cabinet. The CAM vacuum pumps operate continuously via the unswitched receptacle in the instrument cabinet.

Independent vacuum purnps are provided for each loop of the system. Redundant vacuum systems are not furnished, but failure annunciation (low flow rates) is provided and checked periodically to demonstrate operability.

\subsubsection{Building Ventilation Sampling/Monitoring Environmental Conditions.} The building ventilation stack monitoring and sampling instruments are located outside the building. As a result, these monitoring/sampling systems and their respective instruments and components are installed in a weatherresistant cabinet. Other system-related instruments are located within the control room, which has a controlled environment. The cabinet environmental features consist of the following items:

- Thermostatically controlled heater.

- Thermostatically controlled exhaust fan.

- Thermostatically controlled inlet air damper.

- Fluorescent light for illumination.

- Weatherproof doors and latch.

- Temperature out-of-limit alarms.

The environment within the cabinet is controlled by two thermostats. As the temperature in the cabinet drops below $18.3 \pm 2.8{ }^{\circ} \mathrm{C}\left(65 \pm 5{ }^{\circ} \mathrm{F}\right)$, the cabinet heater is activated causing the cabinet temperature to increase to the upper temperature limit of $23.8 \pm 2.8^{\circ} \mathrm{C}\left(75 \pm 5{ }^{\circ} \mathrm{F}\right)$, at which point the power 
to the heater is switched off. The lower temperature setting for the thermostat controlling the heater is set above a lower limit of $10^{\circ} \mathrm{C}\left(50^{\circ} \mathrm{F}\right)$ to avoid moisture condensation problems. A second thermostat prevents the cabinet temperature from increasing to above an upper 1 imit of $51.7{ }^{\circ} \mathrm{C}$

$\left(125^{\circ} \mathrm{F}\right)$ for proper operation of the monitor. Temperatures above $35 \pm 2.8{ }^{\circ} \mathrm{C}$ ( $95 \pm 5^{\circ} \mathrm{F}$ ) will activate the blower and the damper causing outside air to be drawn through the cabinet as a cooling mechanism. Enclosure temperatures exceeding $51.7^{\circ} \mathrm{C}\left(125^{\circ} \mathrm{F}\right)$ or falling below $12.8{ }^{\circ} \mathrm{C}\left(55^{\circ} \mathrm{F}\right)$ will trip alarm switches that ac \pm ivate a local alarm light mounted on the cabinet al arm panel (labeled "HI-LOW MONITOR TEMP), a beacon mounted on the cabinet, and a remote temperature-out-of-range alarm in the control room. Hot summer temperatures occasionally cause the cabinet temperature to exceed $51.7^{\circ} \mathrm{C}\left(125^{\circ} \mathrm{F}\right)$. The installation of an $8,000 \mathrm{Btu} / \mathrm{h}$ refrigerated air conditioning unit on the cabinets is planned.

\section{5,2 LIQUID EFFLUENT STREAMS}

As discussed in Chapter 4, two primary liquid effluent streams associated with the 242-A Evaporator facility are discharged to the environment: the used cooling water stream and the steam condensate stream.

\subsubsection{Used Cooling Water Stream}

The 242-A cooling water waste stream is given the Hanford Site stream code $A C W$. This waste stream consists primarily of cooling water exiting the primary, intermediate, and after condensers (E-C-1, -2 , and -3 ). The condenser cooling water from the evaporator subsequentiy flows into a 24-in. pipe where it combines with eight other nonhazardous contributors (refer to Section 4.1.2.1) to form the overall 242-A Evaporator cooling water effluent stream. All of the contributing streams consist of non-contact cooling water or steam condensate. The 242-A Evaporator process does not involve the intentional addition of hazardous constituents to the steam condensate stream or any of its contributors. Tank Farm Operations limits the use of hazardous materials at its facilities by the use of administrative controls, i.e. procedures that govern the use of such materials in the workplace.

The eight smaller streams flowing into the waste cooling water 24-in.diameter pipe come from the HVAC equipment floor drains, steam condensate from the steam turbine, the drip pans of the raw-water filters, the HVAC relief valve condensate $i$ ines, the HVAC steam conderisate traps, the air compressor cooling water, the compressed air after cooler heat exchanger, and the compressed air separator. This combined effluent is then routed to the 216-B-3 Pond which receives liquids for soil-column disposal. The 100-acre 216-B-3 Pond is used as a percolation pond.

5.2.1.1 Used Cooling Water Flow Rate. During evaporator processing operations, all nine used cooling water contributors described above and in Section 4.1.2.1. are potentially adding liquid to the stream. During shutdown and maintenance periods, however, the condenser cooling water and the water filter catch pan drainage will not contribute to the stream. The 242-A Evaporator runs in campaigns and not year round. Thus, the average flow rate for the cooling water stream varies a great deal over a sustained period 
of time. The flow rate during evaporator campaigns is approximately $13,815 \mathrm{~L} / \mathrm{min}(3,650 \mathrm{gal} / \mathrm{min})$. During shutdown/standby configuration, the used raw-water stream flow rate is approximately $37.85 \mathrm{~L} / \mathrm{min}(10 \mathrm{gal} / \mathrm{min})$. Operation of the 242-A Evaporator during 1988 was representative of process capability. During 1988, the total volume of cooling water discharged from the facility was $6.34 \times 10^{+09} \mathrm{~L}\left(1.67 \times 10^{+09} \mathrm{gal}\right)$.

Flow rate for the used raw-water stream is measured on the 12-in.-diameter used raw-water line upstream of the sample flush valve. The flow rate of the used condenser cooling water contributor is measured by flow indicators $\mathrm{FI}-\mathrm{Cl}-1$ and $\mathrm{FI}-\mathrm{RC} 2-1$. The flow rates of the eight minor contributors of the stream are not monitored.

5.2.1.2 Used Cooling Water Monitoring/Sampling. Used raw water from the condensers is monitored for radiation to detect potential contamination from the waste treatment system, an indication of condenser tube failure. The radiation monitoring sample line feeds a continuous portion of the used rawwater stream through the $\mathrm{R}-\mathrm{C}-2$ shielded radiation monitoring enclosure, which contains a scintillation-type radiation element (RE-RC2-1) coupled to a photomultiplier and amplifier tube assembly. The detector crystal and phototube/amplifier are protected by a stainless steel outer liner. A programmer automatically diverts the sample flow to bypass the radiation cell for 5 min each hour allowing the cell to drain so the radiation background reading may be checked. Radiation information is monitored on the MCS by radiation indicator RI-RC2-1. Shutdown of the 242-A Evaporator is required if radiation exceeds a specified level. Also, a proportional sample of the stream can be taken for laboratory analysis by sampler SAMP-RC2-1. Because the condenser cooling water is the only stream with a potential to contribute hazardous waste to the 242-A Evaporator co0ling water stream, the effluent discharge point is located (by definition) at the R-C-2 sampler and monitor point.

The laboratory sample stream and the radiation monitoring sample stream are continuously passed through the RC-2 sampling/monitoring rack located along the north wall on the second floor elevation of the condenser room [Elevation: $214 \mathrm{~m}$ (702 ft, $6 \mathrm{in.})$ ]. Figure $5-1$ is a simplified flow diagram of the used raw-water effluent monitoring/sampling system.

Samples of the stream are taken periodically with the R-C-2 sampling system and are analyzed for process control requirements. The proportional sampling system consists of an Isolok®* "plunger-type" sampler mounted on the 30.5-cm- (12-in.-) dia used raw-water line. This sampler (SAMP-RC2-1) is located downstream from the point where the two condenser streams (E-C-1 primary condenser and E-C-3 after condenser) combine. The sampler is a composite sampler that automatically takes liquid samples after a predetermined volume has been discharged. The sample obtained is proportional to the flow. The sampler is activated by a Proportional Sample Controller that is integrated with the flow measuring systems. When activated, a plunger is forced into the effluent stream by compressed air and then similarly forced to retract, at which time it withdraws a sample. The sampler withdraws a Illinois.

*Isolok is a trademark of Bristol Engineering Company, Yorkville, 
Figure 5-1. The 242-A Evaporator Used Raw Water System.

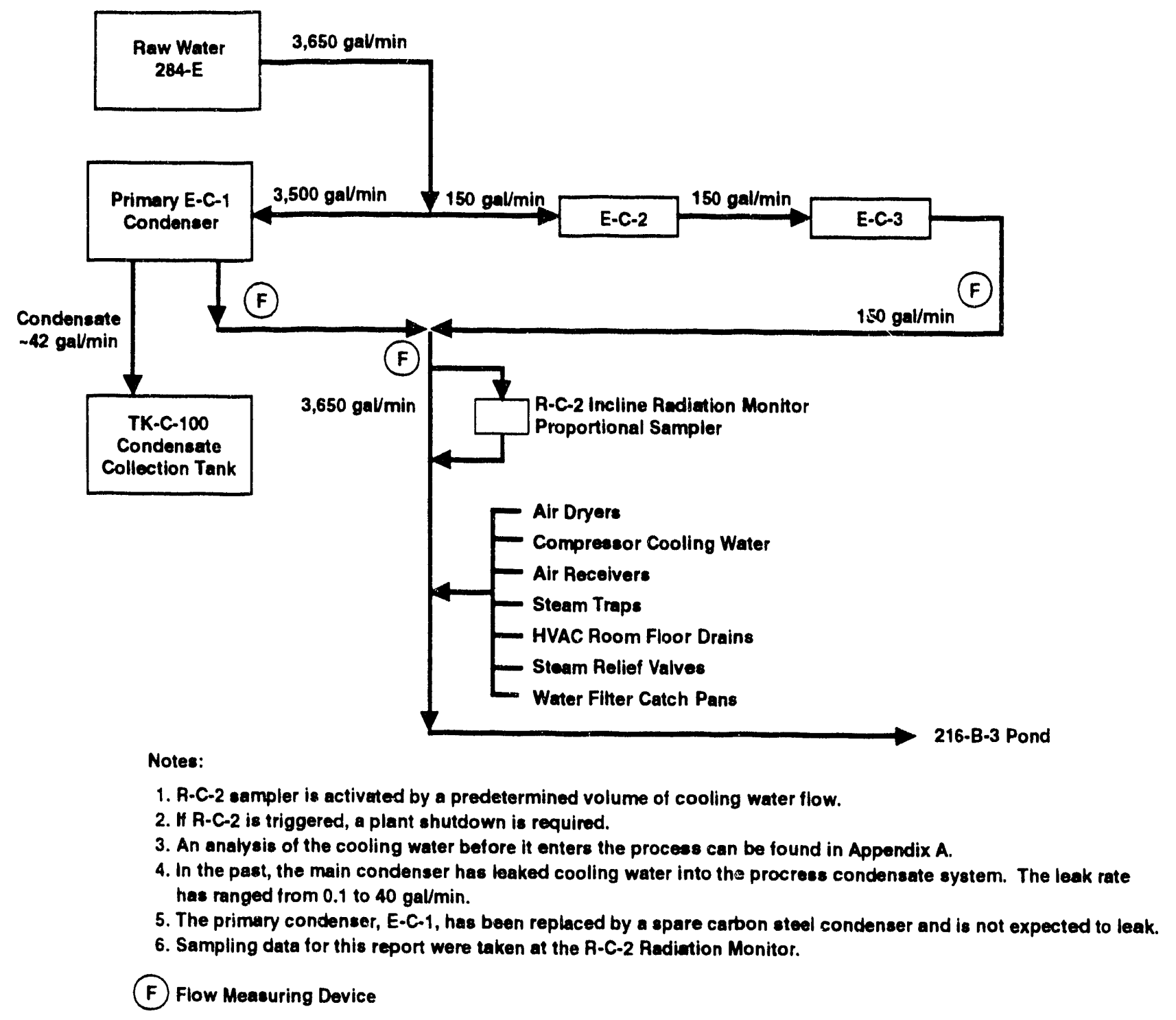


sample at a preset interval. A measuring subassembly in the upper assembly includes a transparent measuring chamber scaled in millimeters for setting sample volume, a sensor for determining when the measuring chamber is full, and associated valves and tubing. The sampler can extract a measured volume from the line and allow it to drain to a 53-L (14-gal) polyethylene compositing bottle located within the RC-2 sampling/moritoring rack. The sampler is located in the northwest corner of the second floor of the condenser room at an elevation of $217 \mathrm{~m}(712 \mathrm{ft}, 4 \mathrm{in}$.) above sea level [3 $\mathrm{m}$ (9 $\mathrm{ft}, 10 \mathrm{in.}$ ) above floor grating].

Laboratory samples are withdrawn from the sample receiving tank in accordance with plant operating procedures (POP). When the evaporator is operating, used raw-water samples are taken daily from the RC-2 sample receiving tank to ensure that the condenser tubes are not leaking and activity is below limits. Two samples are required: a $1-\mathrm{L}$ sample and a $250-\mathrm{mL}$ composite sample. These samples are analyzed at the 222-S Environmental Laboratory for total alpha and total beca. Sample results are recorded in the Sample Log Data Book at the facility.

The limits for activity for the samples are as follows:

- Total alpha (TA): $6.0 \times 10^{-5} \mu \mathrm{Ci} / \mathrm{L}$

- Total beta (TB): $2.0 \times 10^{-2} \mu \mathrm{Ci} / \mathrm{L}$.

These limits are specified in Tank Farm Operating Procedure T0-630-060, Sample Cooling Water from 242-A Via Receiver Carboy RC-2 (WHC 1992e). These limits are set to meet the requirements of WHC-CM-7-5 Part $A$, Part $B$, Part $F$ and Appendix A (WHC 1992i).

If sample results exceed activity limits, supervision is notified and the laboratory is requested to rerun the sample analysis. Normally, URW is routed to 216-B-3 Pond. Contamination above the specified 1 imits requires full evaporator shutdown because of the inability to divert the routing of URW from 216-B-3 Pond.

The radiation monitoring sample point also exists on the $30.5-\mathrm{cm}(12-$ in.) URW line. This point is located upstream of the proportional sampler at an elevation of $219 \mathrm{~m}(720 \mathrm{ft})[5.3 \mathrm{~m}$ (17 ft, $6 \mathrm{in.})$ above the second-level floor grating]. The sample line feeds a continuous stream to the RC-2 sample rack. A programmer automatically diverts the sample flow to bypass the radiation cell (RE-RC2-1) for 5 min each hour while the cell is allowed to drain to check the radiation background reading. A high radiation reading on the cooling water stream is not anticipated and no diversion capability is directly associated with this monitor.

All sampling/monitoring streams passing through the $\mathrm{RC}-2$ sample rack (except the laboratory sample bottle) are discharged to the condenser room floor drain and into the building drainage system, which dumps into DST TK-241-AW-102 and is addressed in this FEMP with the building drainage stream.

5.2.1.3 Used Cooling Water Monitoring/Sampling Environmental Conditions. The sampling and monitoring instrumentation for the used cooling water system is subjected to the environmental conditions in the condenser room and the control room of the facility. Typical temperatures within the condenser room 
are $26.7 \pm 5.6^{\circ} \mathrm{C}\left(80^{\circ} \mathrm{F} \pm 10^{\circ} \mathrm{F}\right)$. The design operating temperature range in the condenser room is from $23.9^{\circ} \mathrm{C}\left(75^{\circ} \mathrm{F}\right)$ to $32.2^{\circ} \mathrm{C}\left(90^{\circ} \mathrm{F}\right)$. The control room is temperature and humidity controlled with a separate ventilation system.

\subsubsection{Steam Condensate Stream}

The 242-A Evaporator steam condensate waste stream is given the Hanford Site stream code ASC. This waste stream consists primarily of steam condensate exiting the reboiler section of the evaporator process. The proposed waste stream designation is that this stream is not a dangerous waste, pursuant to the WAC 173-303, Dangerous Waste Regulations (WAC 1989). A combination of process knowledge and sampling data was used to make this determination.

A total of eleven contributors feed the 242-A Evaporator cooling water waste stream as described in Section 4.1.2.2.

Al1 contributors to the waste stream, except tire heating and cooling jacket streams for TK-E-101 and TK-E-104, converge and then pass through an in-line radiation monitor (RE-EAl-1) before flowing into a 1,893-L (500-gal) flow-measuring tank (TK-C-103). Diversion valves are provided before the flow measurement tank (Valve HV-EAI-2) and after the tank (valve HV-RCl-3). These valves are capable of diverting the flow to the process drain system and ultimately to the waste feed tank (241-AW-102 DST) in case of an upset condition. These valves divert stream flow to the 207-A Retention Basins during normal operations.

The steam condensate flows into one of the three cells at the 207-A Retention Basins until that cell has reached operational capacity (approximately 24 hours during full operation). At that time the steam condensate flow is diverted to one of the two remaining cells. While a cell is being filled, the proportional sampler $(R-C-1)$ is obtaining a sample from the measuring weir (TK-C-103) and compositing it in a large plastic carboy. Once the first cell has been filled, the composite sample is immediately sent to the 222-S Laboratory for radionuclide analysis as an indication of process control. The steam condensate from the full cell is then discharged to the 216-B-3 Pond System (located northeast of the 200 East Area) if the analytical results are within set radionuclide limits. The capability also exists to take bottle samples at the 207-A Retention Basins.

The effluent discharge point for the 242-A Evaporator steam condensate stream is located at the 207-A Retention Basin sample point. This is the point where final sampling and diversion capabilities exist for the stream before discharge to the environment.

5.2.2.1 Steam Condensate Flow Rate. During evaporator processing operations, all 11 steam condensate contributors are potentially adding liquid to the stream. During shutdown and maintenance periods, however, the only active contributor to this waste stream is the room air-sampler pump seal water. This contributor leads to an overall flow of approximately $340 \mathrm{~L} / \mathrm{h}(90 \mathrm{gal} / \mathrm{h})$. 
The 242-A Evaporator runs in campaigns and not year round. Thus, the average flow rate for the steam condensate stream varies greatly over a sustained period of time. Operation of the 242-A Evaporator during 1988 was continuous and, therefore, more representative of process capability than other years. During 1988, the total volume of steam condensate discharged to the 207-A Retention Basins from the facility was $6.55 \times 10^{+07} \mathrm{~L}$ $(1.7 \times 10+07$ gal $)$.

Flow rate for the steam condensate stream is measured at the flow measurement tank (TK-C-103). The waste streali is deposited in TK-C-103 where the flow quantity is measured by a measuring weir contained within the tank. Flow depth over the weir is measured by a weight-factor dip tube assembly and converted to flow quantity by the MCS totalizer FIQ-RCl-1. After a certain volume has passed over the weir, a proportional sampler is signaled to take a sample.

5.2.2.2 Steam Condensate Monitoring/Sampling. The steam condensate is monitored and sampled only for radioactive contamination as an indication of contamination by dangerous waste constituents. Because the 242-A Evaporator is designed and operated to ensure that in any areas where steam may be contaminated by dangerous waste constituents the steam is at a greater pressure than these constituents, contamination is unlikely.

A portion of the steam condensate flow is pumped at a flow rate of $15 \mathrm{~L} / \mathrm{min}$ ( $4 \mathrm{gal} / \mathrm{min}$ ) by sample pump P-RCl-1 from TK-C-103 through a proportional sampler/radiation monitor system $(R-C-1)$ and returned to TK-C-103. A flow-indicating device (FIAS-RC1-1) is monitored by the central MCS to ensure a portion of the steam condensate stream flows through the $\mathrm{R}-\mathrm{C}-1$ system. Figure $5-2$ is a simplified configuration diagram for the steam condensate sampling/monitoring system.

The sampler on the steam condensate system is a composite sampler that automatically takes liquid samples after a predetermined volume has been discharged. The sampler is driven by a total flow determined from the measured flow rate. Thus, the sample obtained is proportional to the flow. Samples of the steam condensate are taken by the proportional sampler (SAMP-RC1-1) into a 18.9-L (5-gal) receiver bottle for laboratory analyses. The sampler is located within the $\mathrm{R}-\mathrm{C}-1$ sample rack on the 210.9-m (692-ft) elevation in the southeast corner of the condenser room.

Samples for laboratory analyses are withdrawn from the steam condensate sample receiving Tank $\mathrm{RC}-1$ after steam condensate has been diverted to another retention basin while the evaporator system is in normal operation and when requested by Tank Farm Process Engineering, in accordance with POPs. The applicable procedure for the steam condensate stream is POP-T0-630-040, Sample/Fill/Drain 242-A Steam Condensate (WHC 1990h). If the process is operating, a $2-L$ composite sample is taken. If the process is shut down or is shutting down, a 4-L sample is taken. Also, a $1-L$ bottle is obtained for a process control sample. In addition, samples of the steam condensate may be obtained from the SC retention basins on the direction of supervision. After sampling is complete, the samples are sent to 222-S Laboratory where they are analyzed for total alpha and total beta. If total alpha is less than $6.0 \times 10^{-5} \mu \mathrm{Ci} / \mathrm{L}$ and total beta is less than $2.0 \times 10^{-2} \mu \mathrm{Ci} / \mathrm{L}$, the condensate 
Figure 5-2. The 242-A Evaporator Steam Condensate System.

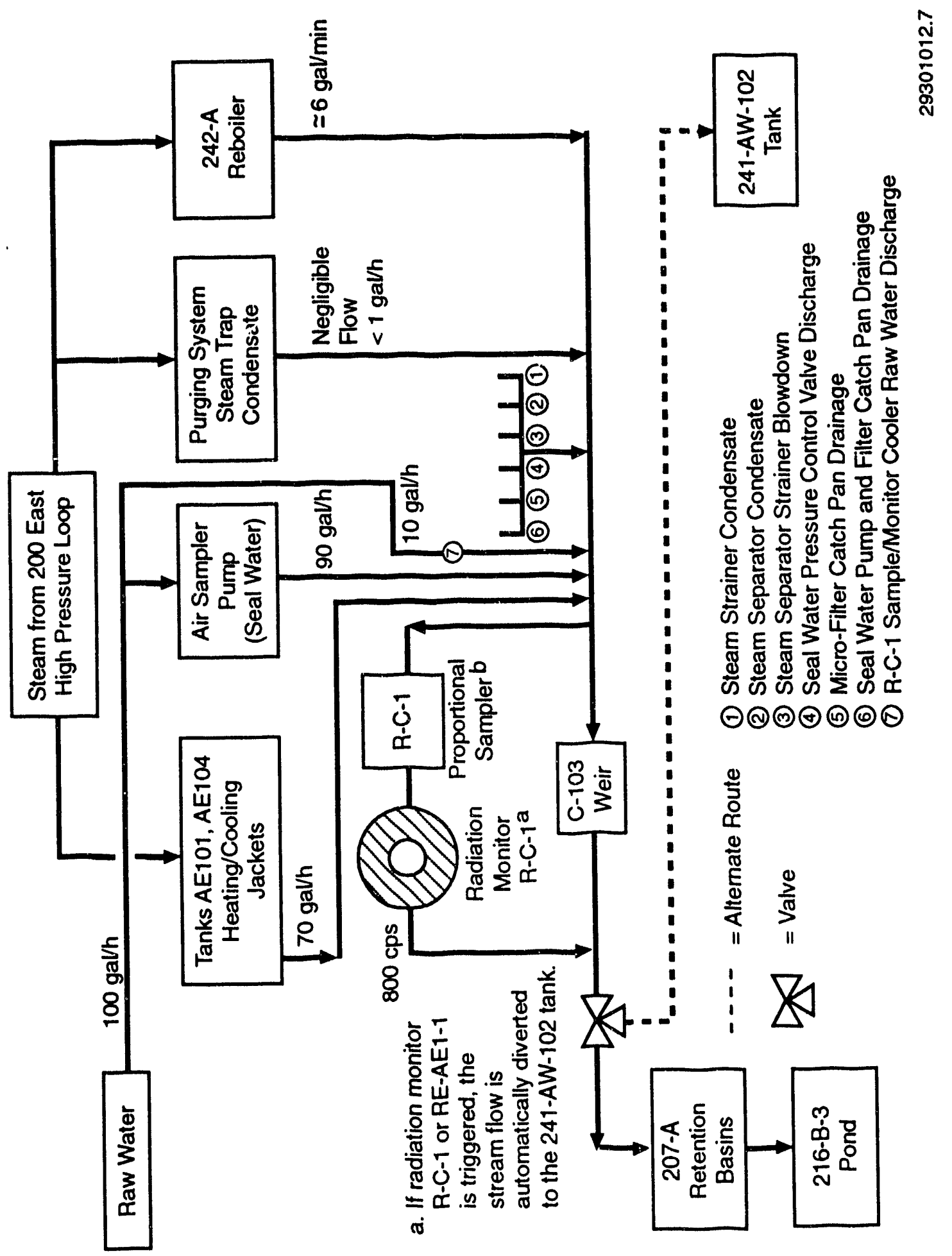


is drained to 216-B-3 Pond. These limits are specified in the operating procedure (WHC 1990h). The limits are set to meet the requirements of WHC-CM-7-5 Part A, Part B, Part F and Appendix A (WHC 1992i).

Steam condensate from the reboiler discharges past an in-line radiation monitor (RE-EAl-1) at the flow measurement weir (TK-C-103). A portion of the steam condensate flow is pumped from the tank through the $R-C-1$ sampling and monitoring system and returned to TK-C-103. A radiation detector and sample cell (RE-RC1-1) is in place as part of the R-C-1 sampling system. The radiation detectors are used to identify any potential leaks of radioactive material into the waste stream. If either radiation monitor detects radiation at a predetermined setpoint above normal background levels, then local and remote high radiation alarms are activated and a signal is sent to an assoc, ated two-way diversion valve to divert the flow to the process drain system and ultimately to the evaporator feed tank (241-AW-102). This prevents discharge of the stream to the 207-A Retention Basins until the radiation cortamination has been identified and the cause of the contamination corrected. This unit is located directly adjacent to the RC-1 sample rack.

The count-rate meter $i r$, the steam condensate monitor system will activate alarms and diversion capability at $80 \mathrm{cps}$ on increasing radiation. A flowindicating device (FIAS-RC1-1) is monitored by the central MCS to ensure a portion of the steam condensate stream flows through the monitor. Alarms indicate $10 \mathrm{w}$-flow conditions of $1.1 \mathrm{~L} / \mathrm{min}(0.30 \mathrm{gal} / \mathrm{min})$ or 1 ess.

Low steam condensate flow-measurement weir levels in Tank $\mathrm{C}-103$ (>17 in. below top of tank) and overflow of Tank $\mathrm{C}-103$ are conditions that activate alarms in the control room and on the MCS.

5.2.2.3 Steam Condensate Sampling/Monitoring Environmental Conditions. The sampling and monitoring instrumentation for the steam condensate system is subjected to the environmental conditions in the condenser room and the control room of the facility. Typical temperatures within the condenser room are $26.7{ }^{\circ} \mathrm{C} \pm 5.6{ }^{\circ} \mathrm{C}\left(80^{\circ} \mathrm{F} \pm 10{ }^{\circ} \mathrm{F}\right)$. The design operating temperature range in the condenser room is from $23.9^{\circ} \mathrm{C}\left(75^{\circ} \mathrm{F}\right)$ to $32.2^{\circ} \mathrm{C}\left(90^{\circ} \mathrm{F}\right)$. The control room is temperature and humidity controlled with a separate ventilation system. 
WHC-EP-0466-1

This page intentionally left blank. 
WHC-EP-0466-1

\subsection{EFFLUENT MONITORING/SAMPLING SYSTEM DESIGN CRITERIA}

\subsection{NEW FACILITIES}

No new facilities that release effluent streams to the environment exist at the 242-A Evaporator.

\subsection{EXISTING FACILITIES}

\subsubsection{Gaseous Effluent Streams}

As described in Section 5.1, the two major airborne effluent release points for the 242-A Evaporator facility are the 296-A-22 stack (vessel ventilation system) and the 296-A-21 stack ("hot area" building ventilation system). Both these streams are sampled and monitored.

6.2.1.1 Effluent Monitoring System General Design. The vessel vent stack (296-A-22) and the building ventilation stack (296-A-21) monitoring systems have been designed and are fabricated from criteria established for the Hanford Site generic stack monitoring/sampling system. The Hanford Site generic stack sampler/monitor system was developed to provide system design and operating capabilities as required in current DOE orders and directives, ANSI guidelines, and Rockwell Hanford Operations Environmental Protection Standards. Hanford Site drawings H-2-92486 through H-2-92504 (RHO 1981a) show the generic systems in detail. The generic stack sampling and monitoring system was designed to provide fixed filter head radioactive particulate record sampling and airborne radiation monitoring capabilities.

The generic stack sampling design provides five combinations of airborne effluent sampling and monitoring. Each option comprises commercially available off-the-shelf components. The site-specific option chosen for the 242-A Evaporator airborne effluent streams is a design that includes a combination of record sample, alpha monitor, and beta/gamma monitor. The original design criteria for the systems was developed in 1980 and published in RHO-CD-1092, 200 Area Stack Sampler-Monitor Systems Upgrade: Generic Systems Applications (RHO 1980a). These criteria were further developed in 1984 as part of an upgrade of 200 Area stack systems and were published in SD-WM-CR-016, FY 1985200 Area Stack Sampler/Monitor Systems Upgrade (RHO 1984).

The design criteria specify that, whenever the stack flow rate varies routinely by more than $\pm 20 \%$, a stack effluent flow-rate monitor with flowtotalizing capability shall be provided. The following is also specified in the design criteria:

- The stack flow-rate monitoring system shall have a flow-rate sensing element located within the stack in a location that will not interfere with the effluent sample extraction probes. The flow-rate transmitter shall provide an electrical signal that is proportional to the stack flow rate, thus controlling a flow-rate indicator and totalizer. 
- Flow-probe sensing lines shall be protected from condensation of moisture.

- Should the stack flor: rate not vary routinely by $\pm 20 \%$, then periodic flow-rate measurements shall be conducted to verify this condition.

- The sample extraction probes within the stacks shall follow, in general, design guidel ines as presented in ANSI N13.1, 1969, Guide to Sampling Airborne Radioactive Materials in Nuclear Facilities (ANSI 1959). Sample probes shall be designed to provide a nearisokinetic representative saniple extraction based on the average stack velocity.

- The average stack velocity shall be determined from velocity profile measurements taken at or near the point of sample extraction.

- Sample probes shall be located a minimum of five duct diameters downstream and two duct diaineters upstream of major flow disturbance points in the exhaust stack, uniess the suitability of an alternate location can be demonstrated through repeatable flow profile measuremenis.

- Sample extracticn probes shall be fiange mounted to the stack to facilitate periodic removaí, inspection, and cleaning activities.

- Sample transport liniss shall extend from the probe connection flange to the instrument cabinet located near the stack. Sample transport lines shall be selected and installed in a manner designed to minimize particle loss attributed to gravity settling, turbulent impaction, and electrostatic effects. Sample transport line runs, bends, and tube transitions shall be minimized to the extent practical. Sample transport line bend radii shall be at least ten times the inside diameter of the transport line. Provisions shall be made to inhibit condensation of moistura within sample transport lines. Sample iransport i ines shall be supported to minimize windinduced vibration effects.

- Generic system assemblies shall be selected to provide fixed-filterhead record sampling and airborne radiation monitoring capabilities. The type of airborne radiation monitoring required is site specific and shall be appropriate for the radionuclides normally expected in exhaust stack effluents.

- The record sample airstream shall be routed through a 47-mm filter to obtain a buildup sample for laboratory analysis. The record sampling system shall have sample flow-rate indicating and totalizing capabilities. A flow-rate regulator shall be provided to maintain a constant flow rate through the collection filter assembly to compensate for filter-loading effects. Audible and visible alarm sigials indicating low sample flow shall be provided locally and to an area subject to frequent or continuous occupancy. The record sample flow rates shall be sized to provide optimum samples for laboratory analyses. The produci of the sample flow rate in 
$\mathrm{ft}^{3} / \mathrm{min}$ ) and the sample collection time (in hours) shall be at least $370 \mathrm{ft}^{3} / \mathrm{min}-\mathrm{h}$. Sample flow rates, however, shall not ixceed $4 \mathrm{ft}^{3} /$ min to maintain filter and sample integrity.

- The CAM system shall have flow rate indicating and regulating capabilities. A flow-rate regulator shall be provided to maintain a constant flow rate through the collection filter assembly to compensate for filter loading effects. The CAM system shall have local readout count-rate meters with strip chart recording capability to a remote area where alarms are to be located. Audible and visible alarms including, but not limited to, high airborne radiation, instrument malfunction, and low sample flow indications, shall be provided locally and in an area subject to frequent or continuous occupancy.

- Monitoring systems shall have the capability to alarm at the timeintegrated equivalent concentration equal to a 4-h release at 5,000 times the DCG-Public as noted in Appendix A of WHC-CM-7-5, Environmental Compliance Manual (WHC 1992i). Monitoring systems shall alarm at release concentrations as low as possible without resulting in an excessive number of alarms caused by normal fluctuations in background or normal fluctuations in releases.

- The stack sampler/monitor system shall operate continuously using the same emergency power backup capabilities as the stack blower fan(s). An elapsed time meter shall be ganged with stack blower-fan operation to provide a measure of exhaust stack operation times. The record sample vacuum pump shall be ganged to exhaust fan operation via a switched receptacle in the system cabinet. The CAM vacuum pump will operate continuously via the unswitched receptacle in the cabinet.

- Particular attention shall be given to the maintainability, testability, and, therefore, reliability of CAM systems. Failure annunciation shail be provided, and the CAM system shall be checked periodically to verify total system response.

- Independent vacuum pumps shall be provided for each loop of the system. Redundant vacuum systems need not be furnished, but failure annunciation (low flow rates) shall be provided and checked periodically to demonstrate operability.

- All gaseous effluent sampling and monitoring system equipment shall be protected from, or resistant to, environmental conditions that may cause damage to the equipment or operation thereof. Routine maintenance shall be performed. Performance evaluations of CAM instrumentation against a known standard shall be done periodically.

\subsubsection{Liquid Effluent Streams}

The steam condensate effluent stream and the used raw-water effluent stream are continuously monitored with in-line radiation monitoring systems 
and are periodically sampled with flow-proportional samplers. This section describes the design criteria required for adequate monitoring and representative sampling.

\subsubsection{Effluent Monitoring/Sampling General Design Criteria. The general} design criteria for liquid effluent sampling and monitoring systems are presented in WHC-CM-4-9, Radiological Design, Section 10.0, REV 0, "Sampling and Monitoring," (WHC 1990g). For sampling systems, the following criteria apply:

1. Sampling systems shall be provided for all liquid effluents that have a potential for exceeding concentrations equivalent to the Drinking Water Standards contained in 40 CFR 141 (EPA 199lg).

2. Sampling systems shall be designed to take a representative sample of the effluent stream. The sample location shall be as close to the environmental discharge point as practical and downstream of the effluent control systems. The sampler should sample only what is discharged to the environment. Samples of a stream diverted from environmental discharge should not be combined with the samples of the discharged effluent.

3. Automatic samplers should operate on a flow-proportional basis as controlled by a flow measurement system. The flow-metering device should be equipped with a flow totalizer for recording total effluent volume released from a given source.

4. Sampling probes should be suspended in the water so as not to pick up particulate matter from the bottom or top of the stream, pond, or basin.

5. The sampler should have a sufficiently high transport velocity to ensure accurate collection and transport of suspended solids to the sample collector. Lengths of sample tubing should be minimized.

6. The sampling system should ensure that no unsampled releases occur as a result of power failure (the sampler shall have backup power).

7. The sampler should be equipped to minimize cross contamination by sample line flushing or other methods.

8. For a batch discharge system, mechanical mixing or other design should ensure reasonable homogeneity of a batch before sampling. The system should have the means for accurate determination of batch volumes to permit volume-weighted compositing of grab (taken at random as opposed to continuous) samples.

For monitoring and diversion systems, the following criteria apply.

1. Monitoring systems shall be provided for all discharged liquid effluents that have the potential of exceeding four times the applicable administrative control limits in WHC-CM-7-5, Westinghouse Hanford Company Environmental Compliance Manual (WHC 1992i). 
2. Monitoring shall be provided for each radionuclide with the potential for exceeding the values in (1) above unless an increase in one radionuclide concentration is accompanied by proportional increases in another type.

3. Monitoring systems should be placed upstream from diversion systems and downstream from effluent treatment systems.

4. Monitors should have distinguishable, audible, and visible highradiation alarms capable of alarming in an area subject to frequent or continuous occupancy.

5. Monitors should have distinguishable, audible, and visible detectorfailure alarms capable of alarming in an area subject to frequent or continuous occupancy. The monitoring system electronics should include a low-count alarm. This module monitors the count rate provided by the electronics and alarms if the count rate drops below a selected level. This acts as a failure alarm for the system components.

6. Monitors should have distinguishable, audible, and visible loss-ofsample alarms capable of alarming in an area subject to frequent or continuous occupancy.

7. Monitors should have distinguishable capability to transmit a realtime measurement to a remote location.

8. Accessibility and maintainability should be considered with respect to the system configuration to accommodate periodic in-place calibration and maintenance.

9. A diversion and retention system shall be coupled with the monitoring system if the potential exists for exceeding the limits contained in WHC-CM-7-5, Westinghouse Hanford Company Environmental Compliance Manual (WHC 1992i).

10. Retention capacity shall be sufficient to retain the volume of liquid that exceeds the applicable limits based on a safety analysis postulated upset. The retention basin should be covered.

11. It should be possible to flush or decontaminate the monitor if a buildup of contamination raises the background radiation levels.

Delivery of a representative portion of the effluent stream to the sampler or monitor depends on the design of the transport line. The following are guidelines for the design of sampler or monitor system transport lines.

- The sampler and monitor should be located as far upstream as practical.

- Traps should be avoided and uphill runs kept as short as practical upstream of the sampler or monitor. 
- Grab sample valves, throttling valves, and flow alarms should be downstream of the sampler and monitor.

- To reduce the number of fittings needed, tubing should be used instead of piping. Sample tubing should be as short as practical, have as few valves and bends as possible, and contain no traps.

- Transport velocity in systems with horizontal or uphill runs should be $61 \mathrm{~cm} / \mathrm{s}(2 \mathrm{ft} / \mathrm{s})$ or greater to ensure transport of suspended solids.

- If a heat exchanger is used, it should be sized to maintain the desired transport velocity and, if practical, the sample should flow downhill.

- The sampler should be upstream of the monitor if both units are on the same transport line.

- The sampler should be separate or separable from the monitor. The two capabilities may be on the same system if either can be isolated by maintenance bypass loops.

Specific design criteria for the in-line radiation monitor systems (denoted as RCl for the steam condensate stream and RC2 for the used raw-water stream) may be found in B-100-P7, Procurement Specification for In-line Radiation Monitoring System - Building 242-A - Project B-100 (ARCHO 1974). This specification states the technical requirements for in-line radiation monitoring systems used to monitor the steam condensate, process condensate, and used raw-water streams. This specification calls for a detector assembiy that uses a scintillation crystal and photomultiplier tube. 


\subsection{CHARACTERIZATION OF CURRENT EFFLUENT MONITORING SYSTEMS}

\subsection{INSTRUMENTATION DESCRIPTION}

\subsubsection{Gaseous Effluent Streams}

This section describes the specific monitoring instrumentation associated with the vessel vent stack $(296-A-22)$ and the building ventilation stack (296-A-21) at the 242-A Evaporator facility.

7.1.1.1 Components of Generic Sampling/Monitoring System. The major components of the generic sampling/monitoring system are described as follows. Figure 7-1 shows the major components.

A. Sample Points from the Exhaust Stack.

- Pick-up probes located inside the stack are designed to be near isokinetic $( \pm 20 \%)$ at the rated flow rate of the stack.

- The sample line is split once to separate the record sample loop from CAM radiation monitoring loop.

- The CAM radiation monitoring loop is split once to separate the alpha CAM loop from the beta/gamma CAM loop.

B. Record Sample Holder.

- Large outside diameter with knurled outer ring for ease of opening.

- Rubber "0" ring gaskets used to seal the sample holder.

- Fine mesh screen behind the sample filter to keep the sample a constant distance from the inlet.

- Sample vacuum side is connected by a flexible line for ease of access.

C. Stack Monitoring CAMs.

- Industry standard CAMs. Currently Eberline AMS-3 for beta/gamma, Eberline Alpha 5 for alpha.

- Hard plumbed into the sample system.

- Hard wired to the central alarm relay system.

- Wired for remote failure alarm. 
Figure 7-1. Generic Airborne Effluent Sampling and Moritoring System.
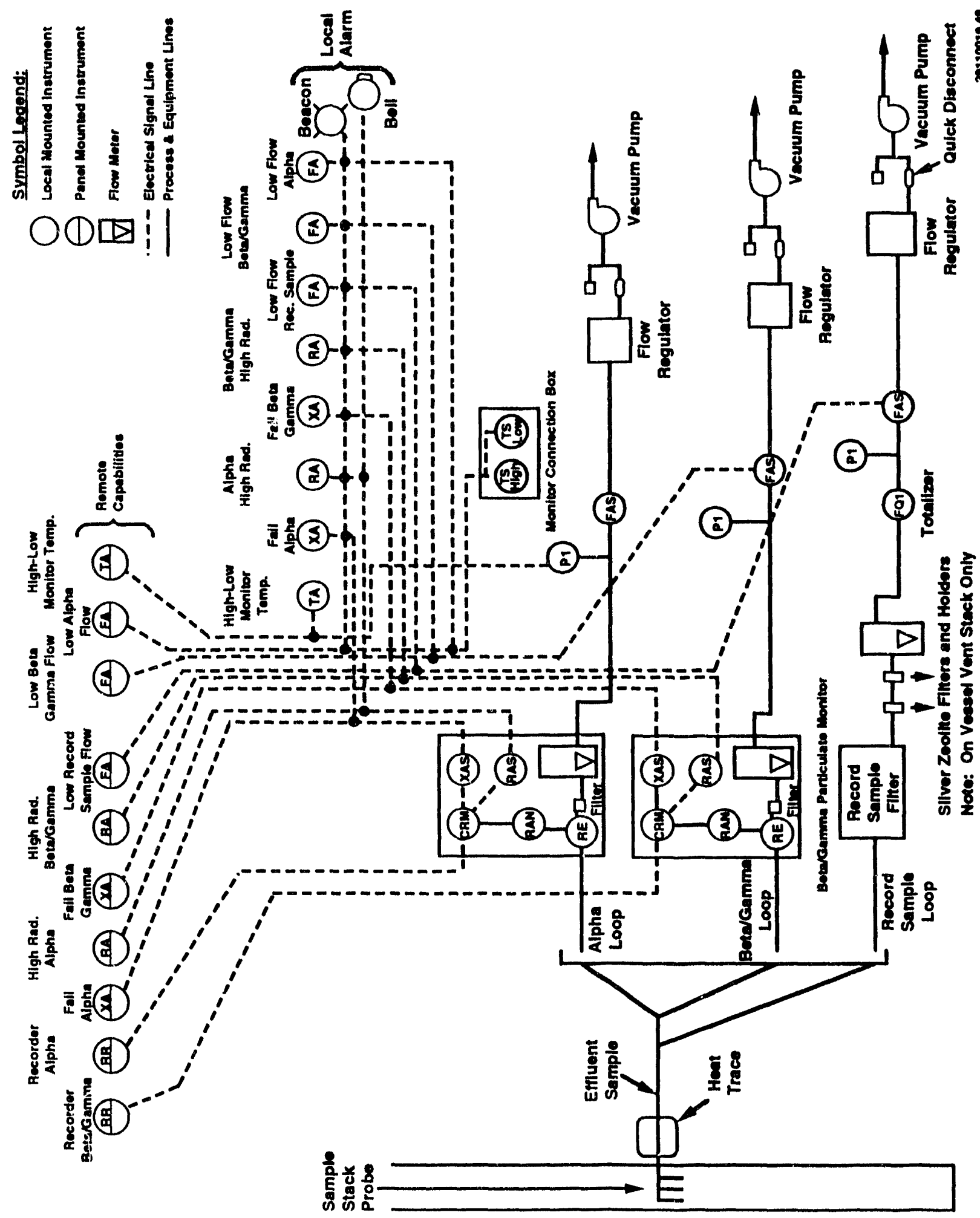
- Electric 30-d linear chart recorders are provided at the control room monitoring alarm panel. The recorders have a scale range of 0 to 100 with an accuracy of $2 \%$ of full scale, a chart speed of $1.9 \mathrm{~cm} / \mathrm{h}(0.75 \mathrm{in.} / \mathrm{h})$, and a response time of ls (full scale).

D. Record Sample Vacuum System consists of the following.

- Rotameter (FI): Reads out in $\mathrm{ft}^{3} / \mathrm{h}$ or $\mathrm{ft}^{3} / \mathrm{min}$ of airflow through the sample paper. Certified accurate to $\pm 10 \%$ o 2.2 std $\mathrm{ft}^{3} / \mathrm{h}$. Operating range: 0.0 to 3.0 std $\mathrm{ft}^{3} / \mathrm{min} \pm 5 \%$.

- Gas Meter Totalizer (FIQ): Industry standard gas meter. Reads out in $\mathrm{m}^{3}$. Measures the total volume of air pulled through the sample filter. Certified accurate to $\pm 5 \% 02.2$ std $\mathrm{ft}^{3} / \mathrm{min}$.

- Flow Alarm Switch (FAS): Trips an alarm at the loss of flow (@1.25 $\mathrm{ft}^{3} / \mathrm{min}$ ) resulting from vacuum pump failure and/or sample filter clogging. Accurate to within $\pm 10 \%$.

- Vacuum Line to the Vacuum Pump: Equipped with a standard quick disconnect for connection to alternative pumps and for sample filter retrieval.

- Stack Flow Switch: Controls a "switched" power outlet providing power to the record sample vacuum pump. Automatically shuts down the record sample vacuum when the stack fans cease operation.

- Record Sample Timer: Provides integrated timing of power supplied to the "switched" power outlet. Resettable 5-digit switch to 99999 . Normally reset to zero when the record sample is exchanged. Certified accurate to $\pm 1 \%$.

E. CAM Sample Vacuum System consists of the following.

- Rotameter (FI): Located on the CAM.

- Vacuum Gauge (PIV)--Industry Standard: Provides an indication of filter plugging resulting from particle buildup.

- Flow Alarm Switch (FAS): Trips an alarm at the loss of flow resulting from vacuum pump failure and/or sample filter clogging.

- Vacuum Line to the Vacuum Pump: Equipped with a standard quick disconnect for connection to alternative pumps and for sample filter retrieval.

F. Alarm Relay Panel Features.

- Provides for simultaneous alarms, local and remote. 
- Neon lamps indicate alarming condition at the stack monitoring/sampling cabinet.

- Provided with a reset switch to clear the remote alarm.

- Alarms: (1) Loss of record sample or CAM vacuum, (2) CAM failures, (3) Cabinet over temperature, and (4) Cabinet low temperature trip the cabinet warning strobe and their respective remote alarms.

- Alarms for high radiation trip the strobe, alarm bell, and their respective remote alarms.

G. Vacuum Supply consists of the following.

- 3 Gast Moto Air-Type Pumps: The pumps are of the centrifugal type with sealing vanes of replaceable graphite.

- Air Sample Flow Regulator: This device bleeds air into the vacuum system to maintain a constant flow through the filter as pluggage occurs. Airflow is adjusted via a set screw on the side of the regulator.

- Bleed-In Air Filter: Filters dirt out of the bleed-in air to the sample pump to prevent pump damage.

- Muffler: Quiets pump exhaust and provides a final filter for sample air before being exhausted to the environment. (Note: The building exhaust stack sample air and the vessel vent stack sample air are fed back into their respective stacks and therefore do not require muffler systems).

- Quick Disconnects: Installed on the vacuum inlet of the regulator. One is in use at all times, the second is a spare. If one vacuum pump becomes disabled, system flow can be maintained by disconnecting the vacuum line from the disabled pump and connecting that line to one of the spare inlet quick disconnects on another pump. A decreased flow rate is sometimes found when operating in this mode, so the disabled pump is repaired as soon as is practically possible. To maintain near-isokinetic flow, the record sample loop is always run on an individual pump.

- Exhaust Lines: Vacuum pumps are exhausted back to the exhaust stack in most installations. Exhaust is always routed to the outside of the cabinet.

7.1.1.2 Continuous Air Monitors. Continuous air monitoring and sampling systems can best be described as an air sampling system designed to sample an air space or air stream by drawing a representative portion of that air through a filter or chamber, coupled with radiation detection instrumentation capable of measuring the radionuclides of interest contained in that air. Together, within the limitations of the detection instrumentation, the two systems are capable of "real-time" monitoring of the sample filter or chamber 
contents as air is being drawn through it. These systems are commonly referred to as CAMs. When the CAM system has been properly calibrated and the alarm set point adjusted to compensate for naturally occurring radioactivity, the CAM can provide alarm capability to alert personnel to an abnormal condition.

The performance specifications for these airborne EMSs are based on the performance of the CAMs and are outlined in Hanford Works Standards HWS-10192, Procurement Specification for Alpha Air Sampler/Monitor (RHO 1978a), and HWS-10193, Procurement Specification for Beta-Gamma Particulate Air Monitor (RHO 1978b). The system operating ranges for the detection of radionuclides depends on the ranges and accuracy of the CAMs, the count-rate meters, and the strip chart recorders. The CAM system specifications used for monitoring the vessel vent and the building ventilation exhausts are described in the following paragraphs.

\section{Eberl ine AMS-3 beta/gamma monitor}

- Detectors: Pancake-type geiger tube, 4.44-cm- $(1.75-$ in.--) diameter, mica window with a density thickness of 1.4 to $2.0 \mathrm{mg} / \mathrm{cm}^{2}$

- Range: 10 to $100,000 \mathrm{cpm}$ on a 4-decade logarithmic scale

- Linearity: Within $\pm 10 \%$ of reading

- Response Time: Varies with count rate to provide constant statistical fluctuation

- Alarm Point: Adjustable over full instrument range

- Temperature Stability: The instrument is operational from $10{ }^{\circ} \mathrm{C}$ to $37.8^{\circ} \mathrm{C}\left(50^{\circ} \mathrm{F}\right.$ to $100^{\circ} \mathrm{F}$ ) with less than $\pm 10 \%$ change in calibration and less than $\pm 20 \%$ change in alarm point

- Airflow Meter: 10 to $100 \mathrm{~L} / \mathrm{min}$

- Count-Rate Meter: $\pm 1 \%$ accuracy

\section{Eberline "Alpha-5" alpha monitor}

- Detector: Silicon-diffused junction type with $490 \mathrm{~mm}^{2}$ area

- Range: 1 to $10,000 \mathrm{cpm}$ (single logarithmic range)

- Linearity: Within $\pm 5 \%$ of reading

- Response Time: Varies with count rate to provide constant statistical fluctuation

- Alarm Point: Adjustable over full instrument range 
- Temperature Stability: The instrument is operational from $-7{ }^{\circ} \mathrm{C}$ to $55^{\circ} \mathrm{C}\left(20^{\circ} \mathrm{F}\right.$ to $\left.130^{\circ} \mathrm{F}\right)$ with less than $\pm 5 \%$ total change in system gain

- Airflow Meter: 10 to $100 \mathrm{~L} / \mathrm{min}$

- Count-rate Meter: $\pm 1 \%$ accuracy.

7.1.1.3 Acceptance Test Procedure. A generic acceptance test procedure (ATP-G-999-00010) (RHO 1981) is initially used at the Hanford Site to verify stack sampling system operability. This procedure provides electrical, mechanical, and alarm function checks as identified in RHO-MA-24l, Installation Criteria for the Generic Airborne Radioactive Contamination Sampling and Monitoring System (RHO 1980b). Applicable sections of this acceptance test procedure are applied to facility-specific airborne effluent monitoring/sampling systems (EMS).

7.1.1.4 Effluent Monitoring System Inspections, Calibrations, and Periodic Testing. Inspections of gaseous EMSs are routinely scheduled and performed by HPTs using procedures in WHC-IP-0692, Health Physics Procedures Manual

(WHC 1992g) and include the following:

- Shiftwise or daily surveillance

- Weekly inspection and relay function test

- Monthly CAM operational performance tests.

Daily or shiftwise inspections are completed to accomplish the following:

- Ensure that the record sample holder is securely closed

- Ensure that the CAM and record sample airflows are set to the proper flow rate

- Ensure proper instrument power exists and that the POWER light(s) on the instrument(s) are illuminated

- Note the background meter reading on the beta CAM

- Ensure the beta CAM is being operated in the "Background Subtraction" mode

- Ensure the COUNTING indicator light is illuminated on the alpha CAM

- Ensure the alpha CAM is being operated in the PHA-SUB mode

- Ensure sufficient chart paper at the recorder(s) location. The chart(s) is signed and dated, and the time is marked by the HPT performing the daily inspection.

The weekly inspection and relay function test is called the Weekly Monitoring System Operability Inspection. These inspections are scheduled concurrently with the Weekly Effluent Sample Filter Changeout and are conducted to accomplish the following. 
A. Inspect the record sampler system for the following:

- Sample holder rubber "0" rings serviceability. The inspection looks at the sealing surface for obvious cracks, cuts, or gouges. The rubber should be pliable and slightly lubricated.

- Stack flow sensor calibration date

- Rotameter calibration date and adjustment. The flow-rate reading on the meter is recorded on a checklist.

- Gas meter totalizer calibration date and proper meter movement

- Flow alarm (pressure) switch calibration date and functional test

- Vacuum system leaks, smooth operation of the pumps, and proper installation of bleed air filters, exhaust filters, and vacuum pump power (plugged into the "switched" power outlet)

- Vacuum gauge calibration date and an indication of system vacuum

- The correctness of the time accumulated on the timer since the sample was last changed

- Sample flow regulator calibration date and adjustment.

B. Record the Inspection Date and the applicable information in the boxes provided on the Gaseous Effluent Monitoring System Evaluation Checklist.

C. Inspect the CAM system for the following.

- Proper airflow through, and readability of, the rotameters. The flow-rate readings are recorded on the checklist.

- CAM calibration stickers and due dates.

- Condition of rubber "0" rings. The sealing surfaces visually inspect for obvious cracks, cuts, or gouges. The rubber should be pliable and slightly lubricated.

- Correct Alarm Set Point (ASP). This is to ensure that the CAM is set at the ASP determined by Health Physics Radiological Engineering (listed on the CAM check sheet). The ASP is entered on the checklist.

- Background meter readings on the CAMs. This check is taken with a sample filter that has been in use at least $24 \mathrm{~h}$, or has reached equilibrium. The "Counting" indicator light on the alpha CAM is checked for illumination. The background readings are entered on the checklist. 
- Beta CAM operation in the background subtraction mode and Alpha CAM operation in the PHA-SUB mode.

- Flow Alarm (pressure) Switch calibration dates and functional test.

- Obvious leaks, smoothly running pumps, bleed air, and proper installation of the exhaust filter on the vacuum system.

D. Inspect Monitoring/Sampling Cabinet for the following:

- General Housekeeping: Excessive dust and dirt, debris, loose sample papers, junk parts, etc.

- Proper Ventilation, (i.e., heater function in the winter months; spring-loaded louvers open and fan on in the summer months). Temperature inside the cabinet should be above $4.5{ }^{\circ} \mathrm{C}$ $\left(40^{\circ} \mathrm{F}\right)$ in the winter and less than $40.5^{\circ} \mathrm{C}\left(105^{\circ} \mathrm{F}\right)$ in the summer.

- Miscellaneous Cabinet Maintenance: lighting, strobe warning lamp illumination, hinges and door latch, etc.

The monthly system operability test and inspection is scheduled concurrently with the Monthly Routine CAM Operational Performance Test. The following is accomplished.

- The weekly inspection previously described is performed.

- The required monthly routine CAM operational performance tests are accomplished, including functional tests of the alarm circuitry.

- The HPT Gaseous Effluent Monitoring System Evaluation Checklist is exchanged and returned to the HP field office for review and retention. The applicable information is entered at the top of the new checklist.

Initial efficiency tests are performed on all newly installed CAMs and after any maintenance or calibration of an installed CAM.

Operational performance tests are performed on operating or portable CAMs in service on a monthly basis. Alarm circuitry is function tested quarterly at a minimum or as required by the Facility Scheduled Radiation Survey Program.

Alpha CAM performance efficiencies are always greater than $7 \%$ and 1 ess than $20 \%$. If the efficiencies are less than $7 \%$, or if any of the alarm circuitry is inoperable, then the CAM is rejected.

Beta CAM performance efficiencies are always greater than $10 \%$ for ${ }^{137} \mathrm{CS}$ and ${ }^{99} \mathrm{Tc}, 15 \%$ for ${ }^{90} \mathrm{Sr}$, and less than $40 \%$ for any isotope. If the efficiencies are less than or greater than the above limits, respectively, the CAM is rejected. 
Periodic assessment of air sampler flow indicator accuracy, and/or possible sampler air inleakage of air sampling equipment used by HP to sample or monitor workplace breathing air, is performed in compliance with ANSI N13.6-1966, Practice for Occupational Radiation Exposure Records Systems (ANSI 1966), to demonstrate "requisite accuracy under the conditions of use" as recommended in ANSI N13.1-1969, Guide to Sampling Airborne Radioactive Materials in Nuclear Facilities (ANSI 1969).

These tests are conducted as follows:

- Whenever a rotameter is replaced on a fixed-head air sampier

- Whenever a CAM is replaced at the assigned CAM sample location

- At quarterly intervals at a minimum frequency

- Whenever the CAM rubber "0" rings is replaced

- At any time that the indicated reading of the sampling device is believed to be suspect.

7.1.1.5 Effluent Monitoring/Sampling Alarming/Diversion Set Points. The CAM electronic assemblies include an adjustable ASP. Some CAM systems are equipped with both a mid-range "alert" alarm and a "high trip" alarm point. In many instances, the mid-range alarm is provided only at or near the sample location and is a visual alarm. A high alarm trip will always trigger audible, visual, and any available remote alarms. When a mid-point al arm is used, it is expressed as a fraction or a percentage of the high alarm point. Depending on system design, some systems' failure will trip a failure lamp, others will cause a fail-safe light to go out.

The primary objective when calculating the CAM ASP is to allow personnel sufficient warning of a significant release or potential environmental release of airborne radioactivity, while attempting to minimize spurious alarms. The ASPs are determined by calculating the meter reading equivalent to a predetermined air concantration accumulation in a given amount of time. Normally this is calculated as a set number of $D^{\circ} G^{*}$ or derived air concentrations (DAC)** exposure in $1 \mathrm{~h}$.

*Derived Concentration Guide. Those concentrations in air or water that an individual would inhale/ingest in a year to result in $5,000 \mathrm{mrem} / 50 \mathrm{yr}$ dose commitment to occupationally exposed individuals or those concentrations that. would result in a maximum effective committed dose equivalent of $100 \mathrm{mrem} / \mathrm{yr}$ to the public.

$\star *$ Derived Air Concentrations (DAC). The DAC is a limit on the amount of a radionuclide permitted in air, based on limiting the exposure an occupational worker would receive from breathing the air for a sustained period. It is derived by dividing the annual limit on intake for a given radionuclide by the volume of air breathed by an average worker during a working (not calendar) year, $2.4 \times 10^{3}$. The annual limit on intake is defined as the activity of radionuclide which taken alone would irradiate a person to the limiting value for control of the workplace. 
The equilibrium point of the naturally occurring radioactivity on the sample is taken into account when calculating the set point. At CAM sample locations where wide fluctuations in the natural activity occur, the set point is adjusted to compensate for the increased natural activity. For locations where the natural activity fluctuations are both frequent and severe, it may be necessary to calculate an "average" background value into the ASP. This background value is derived from past operating experience at that sample location.

The ASPs are determined by Radiological Engineering for environmental release points and by HP for work place monitoring. Facility HP Management or Radiological Engineering may require that one standard CAM ASP or DAC-Hour value be used throughout a facility (e.g., for alpha: $20 \mathrm{cpm}$ or $40 \mathrm{cpm}$; or for beta: 3,000 cpm, 4,000 cpm). The predetermined ASP or DAC-Hour value for the individual facility, as indicated on the Scheduled Routine Task Description for CAM Inspection, is the site-specific value normally used. The ASPs may be temporarily increasec to accommodate verified natural activity (radon/thoron) changes.

7.1.1.5.1 Alpha Alarm Set Point. For alpha CAMS, the following criteria apply when establishing site-specific CAM ASPs.

- In ireas not requiring respiratory protection, the maximum ASP for workplace alpha CAMs shall be no greater than $40 \mathrm{cpm}$ above verified naturally occurring uackground count rate. The ASP of $40 \mathrm{cpm}$ is a maximum allowable value. Individual HP management may require that a lower value be used.

- In areas of low potential for airborne contamination that do not require respiratory protection, the : iximum allowable ASP is $80 \mathrm{cpm}$. In all circumstances not requiring respiratiory protection, $80 \mathrm{cpm}$ is he maximum a?lowed ASP regardless of naturally occurring background.

- Elevated CAM ASPS require periodic (every 2 to $4 \mathrm{~h}$ for areas occupied by personnel and depending on contamination potential requirements) checks of the CAM count rate during periods of elevated "radon" concentrations.

- In areas where respiratory protection devices are required, the alpha CAM ASP shall be no greater than 40 times the protection factor (PF) provided by the minimum required respiratory protection device. This ASP is a maximum permissible value and shall not exceed $2,000 \mathrm{cpm}(40 \times 50=2,000)$. Individual facil:ty Radiological Engineering groups $n$, request tiat a lower number be used. 
The equation used to calculate an alpha CAM ASP can be expressed as follows:

$$
\frac{(A \cdot V \cdot E \cdot t)}{2.0 \times 10^{-11}}=A S P
$$

Where:

$A=$ DAC limit [for ${ }^{239} \mathrm{Pu}$ in this example]

$V=$ flow rate of air through sample in $\mathrm{ft}^{3} / \mathrm{h}$

$E$ = instrument efficiency [assumed $8.5 \%$ in this example]

$t=$ maximum time in hours allowable at DAC limi $i$

(in this example $t=20$ )

$2.0 \times 10^{-11}=$ conversion constant for $\mathrm{dpm} / \mu \mathrm{ci} / \mathrm{mL}$ (assumed 80 to $85 \%$ collection efficiency)

NOTE: Actual values used are those required by facility HP management

Example:
[A]
$[(2 \mathrm{E}-12)$
$\left[\begin{array}{l}V \\ (120)\end{array}\right)$
$(2)$
[E]
$[t]$
$(20)] / 2.0 \mathrm{E}-11=20 \mathrm{cpm}$ above background.

7.1.1.5.2 Beta Alarm Set Point. For beta CAMS, the following criteria apply when establishing site-specific CAM ASPs:

- The background reading used to establish the ASP is an approximate background reading after the sample has reached an equilibrium with the naturally occurring isotopes in the atmosphere (radon/thoron). It is necessary to draw an air sample through the CAM for at least $2 \mathrm{~h}$ to determine equilibrium.

NOTE: The current background value already indicated on the CAM may be used to establish the ASP if the CAM has had airflow through the filter in that location for at least $2 \mathrm{~h}$ so that ambient background level is reached.

- Facilities that use ${ }^{137} \mathrm{Cs}$ or ${ }^{99} \mathrm{Tc}$ to establish CAM counting efficiencies may use a $15 \%$ minimum counting efficiency for ${ }^{90} \mathrm{Sr}$ (most limiting isotope) for the calculation of ASPS.

- In areas not requiring respiratory protection, the maximum ASP shall not exceed 15,000 cpm, regardless of naturally occurring background.

EXEMPTION: Facilities in which it has been documented that ${ }^{90} \mathrm{Sr}$ is not the limiting isotope may use the 1 DAC- $h$ ASP value based on the limiting isotope (s) present (e.g., ${ }^{137} \mathrm{Cs},{ }^{99} \mathrm{TC}$ ). 
NOTE: An ASP of $15,000 \mathrm{cpm}$ shall not be used if the beta CAM is used for the detection of airborne uranium. Individual HP management may require that a lower value be used (see previous "Note").

- Elevated CAM ASPs require periodic (every 2 to $4 \mathrm{~h}$ for areas occupied by personnel and depending on contamination potential requirements) checks of the CAM count rate during periods of elevated radon concentrations.

- In areas where respiratory protection devices are required, the beta CAM ASP shall be no greater than $80,000 \mathrm{cpm}(80 \%$ of full scale of the (AM). This value is well within the factor PF of 50 provided by the full-face filter respirator. In areas of confirmed airborne contamination, open face air samplers run for short sample periods should be used to assess air concentrations.

NOTE: The ASP of $80 \%$ of operating scale is a maximum allowed value. Individual facility HP Management may require that a lower number be used. follows:

The equation used to calculate a beta CAM ASP can be expressed as

$$
\frac{(A \cdot V \cdot E \cdot t)}{2 \cdot 0 \times 10^{-11}}=A S P
$$

Where:

$A=D A C$ limit $\left[{ }^{90} \mathrm{Sry}\right.$ in this example $\left.=2 \times 10^{-09} \mu \mathrm{Ci} / \mathrm{mL}\right]$

$V=$ flow rate of air through sample in $\mathrm{ft}^{3} / \mathrm{h}=120 \mathrm{ft}^{3} / \mathrm{h}$

$E=$ instrument efficiency $\left[15 \%\right.$ for ${ }^{90} \mathrm{Sr}$ check source]

$t=$ maximum time in hours allowable at DAC limit (normally 1 DAC-Hour).

$2.0 \times 10^{-11}=$ conversion constant for $\mathrm{dpm} / \mu \mathrm{ci} / \mathrm{mL}$ (assumed $80-85 \%$ collection efficiency)

NOTE: Actual values used are those required by facility HP management

Example:
[A]
$\left[\left(2 \times 10^{-9}\right)\right.$
[V]
$\stackrel{[E]}{[.15]}(1)] / 2.0 \times 10^{-11}=1,800 \mathrm{cpm}$ above baskground
$[\mathrm{t}]$
[ASP]

7.1.1.5.3 Continuous Air Monitor Surveillance During Periods of Radon/Thoron Buildup. Radon, Natural Activity Identification. The presence of naturally occurring (radon) radioactivity in the atmosphere sometimes increases because of local weather conditions and causes CAMs to alarm. Temperature inversions are the major cause of high CAM backgrounds caused by radon. 
Although a radon problem is sometimes suspected, it is always assumed that the activity on the air sample is caused by the dispersible contamination present in the facility, until positive identification is made.

During periods of increased radon background, CAM chart recorders are carefully monitored for a gradually increasing count rate on the recorder or the meter, which could indicate an actual release that is being partially masked by the radon background.

In lieu of a second air sample being available for count, it is permissible to contact other facilities' HP offices by telephone to verify that there is a widespread radon buildup problem. Contacting other facilities is recommended, but not required, even where the second air sample is available for decay count.

\section{Thoron Activity Identification}

Thoron gas, a decay product of thorium, corresponds to radon gas in the uranium decay series.

Like radon, the presence of naturally occurring thoron activity in the atmosphere sometimes increases because of local weather conditions or poor ventilation in the immediate area.

Because of the short half-life of thoron and its initial daughters, naturally occurring concentrations of thoron are a relatively small contributor to the naturally occurring background on an air sample.

Thoron gas and decay products become a problem in or near facilities where quantities of ${ }^{232} \mathrm{Th}$ have been processed. The processing of thorium significantly increases the concentration of thoron gas $\left({ }^{220} \mathrm{Rn}\right)$.

The ${ }^{212} \mathrm{~Pb}$, which has a half-1ife of $10.6 \mathrm{~h}$, becomes the most readily identifiable isotope of concern when dealing with a thoron gas buildup.

Positive identification of elevated radon and/or thoron activity may result in a controlled increase of the ASPs to eliminate the nuisance alarm.

Continuous Air Monitoring Surveillance During Periods of Radon/Thoron Buildup

Periodically (every 1 to $2 \mathrm{~h}$ ) during the shift, if the area is to be occupied by personnel, the CAM record strip chart is reviewed. It is examined for (1) a reduction in the background on the sample, indicating an end to the radon buildup problem and (2) a gradual increase of the reading on the strip chart. This could indicate either an increasing concentration of radon buildup, necessitating a repeat of the radon/thoron evaluation, or an actual release that has been partially masked by the high radon background.

7.1.1.6 Vessel Vent Instrumentation. The alpha and beta CAMs specifications used in the vessel vent monitoring system are discussed in Section 7.1.1.2. Table 7-1 itemizes other specific instrumentation in the vessel vent exhaust sampling/monitoring systems. Also itemized within this table are the specific locations, calibration frequencies, and related calibration procedures for 
Table 7-1. Monitoring Instrumentation for 242-A Vessel Ventilation System Exhaust Stack 296-A-22. (4 sheets)

\begin{tabular}{|c|c|c|c|}
\hline Instrument type & $\begin{array}{l}\text { Physical } \\
\text { location }\end{array}$ & $\begin{array}{l}\text { Calibration type, } \\
\text { frequency, and } \\
\text { procedure No. }\end{array}$ & $\begin{array}{l}\text { Alarming or } \\
\text { diversion set } \\
\text { points }\end{array}$ \\
\hline $\begin{array}{l}\text { FAS-VV-1 } \\
\text { Alpha Loop } \\
\text { Flow alarm switch }\end{array}$ & $\begin{array}{l}\text { In-cabinet } \\
\text { local mounted } \\
\text { instrument }\end{array}$ & $\begin{array}{l}\text { 6-mo lmtd. cal.: } \\
\text { PSCP-6-029 } \\
\text { Weekly function: } \\
\text { HPT Proc. 5.2.2.6 }\end{array}$ & $\begin{array}{l}\text { Decreasing flow } \\
\text { condition al arms } \\
\text { at } 1.25 \mathrm{ft}^{3} / \mathrm{min}\end{array}$ \\
\hline $\begin{array}{l}\text { FAL-VV-1A } \\
\text { Alpha sample flow } \\
\text { low local indication } \\
\text { amber light }\end{array}$ & $\begin{array}{l}\text { Local alarm } \\
\text { panel box } \\
\text { assembly }\end{array}$ & $\begin{array}{l}\text { Weekly functional } \\
\text { test: } \\
\text { HPT Proc. 5.2.2.6 }\end{array}$ & $\begin{array}{l}\text { Decreasing flow } \\
\text { condition alarms } \\
\text { at } 1.25 \mathrm{ft}^{3} / \mathrm{min}\end{array}$ \\
\hline $\begin{array}{l}X A-V V-2 \\
\text { Alpha monitor fail } \\
\text { local al arm amber } \\
\text { light }\end{array}$ & $\begin{array}{l}\text { Local alarm } \\
\text { panel box } \\
\text { assembly }\end{array}$ & $\begin{array}{l}\text { Monthly functional } \\
\text { test: } \\
\text { HPT Proc. } 7.3 .1 \\
\text { PSCP-3-003 }\end{array}$ & $\begin{array}{l}\text { Alarms upon } \\
\text { failure of system } \\
\text { components }\end{array}$ \\
\hline $\begin{array}{l}X A-V V-1 \\
\text { Alpha monitor } \\
\text { failure alarm }\end{array}$ & $\begin{array}{c}\text { Control room: } \\
\text { - MCS }\end{array}$ & $\begin{array}{l}\text { Monthly functional } \\
\text { test: } \\
\text { HPT Proc. } 7.3 .1 \\
\text { PSCP-3-003 }\end{array}$ & $\begin{array}{l}\text { Alarms upon } \\
\text { failure of system } \\
\text { components }\end{array}$ \\
\hline $\begin{array}{l}\text { RI-VV-ALP } \\
\text { VV Exh stack alpha } \\
\text { Radiation } \\
\text { MCS Input } \\
\text { Range: } 1-10,000 \mathrm{cpm} \\
\end{array}$ & $\begin{array}{c}\text { Control room: } \\
\bullet \text { MCS }\end{array}$ & $\begin{array}{l}\text { Weekly operability } \\
\text { inspection: } \\
\text { HPT Proc. } 5.2 .2 .6\end{array}$ & $N / A$ \\
\hline $\begin{array}{l}\text { RSH-VV-ALP } \\
\text { High alpha radiation } \\
\text { alarm } \\
\text { MCS Input }\end{array}$ & $\begin{array}{c}\text { Control room: } \\
- \text { MCS } \\
- \text { CASS }\end{array}$ & $\begin{array}{l}\text { Monthly functional } \\
\text { test: } \\
\text { HPT Proc. } 7.3 .1 \\
\text { PSCP-3-003 }\end{array}$ & $20 \mathrm{cpm}$ \\
\hline $\begin{array}{l}\text { RA-VV-3 } \\
\text { High alpha radiation } \\
\text { alarm amber light }\end{array}$ & $\begin{array}{l}\text { Local alarm } \\
\text { panel box } \\
\text { assembly }\end{array}$ & $\begin{array}{l}\text { Monthly functional } \\
\text { test: } \\
\text { HPT Proc. 7.3.1 } \\
\text { PSCP-3-003 }\end{array}$ & $20 \mathrm{cpm}$ \\
\hline $\begin{array}{l}\text { RM-VV-1 } \\
\text { Alpha air monitor }\end{array}$ & $\begin{array}{l}\text { Local } \\
\text { rack-mounted } \\
\text { unit }\end{array}$ & $\begin{array}{l}\text { Monthly overall } \\
\text { calibration: } \\
\text { PSCP-3-003 } \\
\text { Monthly source } \\
\text { check, cleaning } \\
\text { and performance } \\
\text { test: } \\
\text { HPT Proc. } 7.3 .1\end{array}$ & $20 \mathrm{cpm}$ \\
\hline
\end{tabular}


Table 7-1. Monitoring Instrumentation for 242-A Vessel Ventilation System Exhaust Stack 296-A-22. (4 sheets)

\begin{tabular}{|c|c|c|c|}
\hline Instrument type & $\begin{array}{l}\text { Physical } \\
\text { location }\end{array}$ & $\begin{array}{l}\text { Calibration type, } \\
\text { frequency, and } \\
\text { procedure No. }\end{array}$ & $\begin{array}{c}\text { Alarming or } \\
\text { diversion set } \\
\text { points }\end{array}$ \\
\hline $\begin{array}{l}\text { Count-rate meter } \\
\text { (Rescaled) }\end{array}$ & $\begin{array}{l}\text { Alpha air } \\
\text { monitor }\end{array}$ & $\begin{array}{l}\text { Monthly efficiency } \\
\text { test: } \\
\text { HPT Proc. } 7.3 .1 \\
\text { 1-mo cal ibration: } \\
\text { PSCP-3-003 }\end{array}$ & $N / A$ \\
\hline $\begin{array}{l}\text { Alpha loop } \\
\text { flow regulator } \\
\text { assembly }\end{array}$ & $\begin{array}{l}\text { In-cabinet } \\
\text { local mounted } \\
\text { equipment }\end{array}$ & $\begin{array}{l}\text { 6-mo lmtd. cal.: } \\
\text { PSCP-6-029 } \\
\text { Daily adjustment: } \\
\text { HPT Proc. 5.2.2.6 }\end{array}$ & $\begin{array}{l}\text { Maintains sample } \\
\text { flow rate of } 2.0 \\
\text { std } \mathrm{ft}^{3} / \mathrm{min}\end{array}$ \\
\hline $\begin{array}{l}\text { PI-VV-1 } \\
\text { Alpha sample } \\
\text { pressure indicator } \\
\text { vacuum gage }\end{array}$ & $\begin{array}{l}\text { In-cabinet } \\
\text { local mounted } \\
\text { instrument }\end{array}$ & $\begin{array}{l}\text { 6-mo calibration } \\
\text { PSCP-4-091 }\end{array}$ & $N / A$ \\
\hline $\begin{array}{l}\text { FAL-VV-2A } \\
\text { Low-flow beta/gamma } \\
\text { alarm amber light }\end{array}$ & $\begin{array}{l}\text { Local alarm } \\
\text { panel box } \\
\text { assembly }\end{array}$ & $\begin{array}{l}\text { Neekly functional } \\
\text { test: } \\
\text { HPT Proc. 5.2.2.6 }\end{array}$ & $\begin{array}{l}\text { Decreasing flow } \\
\text { condition a larms } \\
\text { at } 1.25 \mathrm{ft}^{3} / \mathrm{min}\end{array}$ \\
\hline $\begin{array}{l}\text { FAS-VV-2 } \\
\text { Beta Loop } \\
\text { Flow alarm switch }\end{array}$ & $\begin{array}{l}\text { In-cabinet } \\
\text { local mounted } \\
\text { instrument }\end{array}$ & $\begin{array}{l}\text { 6-mo lmtd. cal : } \\
\text { PSCP-6-029 } \\
\text { Weekly function: } \\
\text { HPT Proc. 5.2.2.6 }\end{array}$ & $\begin{array}{l}\text { Decreasing flow } \\
\text { condition alarms } \\
\text { at } 1.25 \mathrm{ft}^{3} / \mathrm{min}\end{array}$ \\
\hline $\begin{array}{l}\text { XA-VV-3 } \\
\text { Beta/gamma monitor } \\
\text { failure alarm amber } \\
\text { light }\end{array}$ & $\begin{array}{l}\text { Local alarm } \\
\text { panel box } \\
\text { assembly }\end{array}$ & $\begin{array}{l}\text { Monthly functional } \\
\text { tests: } \\
\text { HPT Proc. } 7.3 .2 \\
\text { PSCP-3-002 }\end{array}$ & $\begin{array}{l}\text { Alarms upon } \\
\text { failure of system } \\
\text { components }\end{array}$ \\
\hline $\begin{array}{l}X A-V V-1 \\
\text { Beta/gamma monitor } \\
\text { failure alarm }\end{array}$ & $\begin{array}{c}\text { Control room: } \\
\text { MCS }\end{array}$ & $\begin{array}{l}\text { Monthly functional } \\
\text { tests: } \\
\text { HPT Proc } 7.3 .2 \\
\text { PSCP-3-002 }\end{array}$ & $\begin{array}{l}\text { Alarms upon } \\
\text { failure of system } \\
\text { components }\end{array}$ \\
\hline $\begin{array}{l}\text { RI-VV-B/G } \\
\text { VV Exh stack } \\
\text { beta/gamma Radn. } \\
\text { MCS input } \\
\text { Range: } 10-99999 \mathrm{cpm}\end{array}$ & $\begin{array}{c}\text { Control room: } \\
\text { - MCS }\end{array}$ & $\begin{array}{l}\text { Weekly operability } \\
\text { inspection: } \\
\text { HPT Proc. 5.2.2.6 }\end{array}$ & $N / A$ \\
\hline $\begin{array}{l}\text { RSH-VV-B/G } \\
\text { High beta/gamma } \\
\text { radiation alarm } \\
\text { MCS input }\end{array}$ & $\begin{array}{c}\text { Control room: } \\
\text { - MCS } \\
\text { - CASS }\end{array}$ & $\begin{array}{l}\text { Monthly functional } \\
\text { tests: } \\
\text { HPT Proc. } 7.3 .2 \\
\text { PSCP-3-002 }\end{array}$ & $2,000 \mathrm{cpm}$ \\
\hline
\end{tabular}


Table 7-1. Monitoring Instrumentation for 242-A Vessel Ventilation System Exhaust Stack 296-A-22. (4 sheets)

\begin{tabular}{|c|c|c|c|}
\hline Instrument type & $\begin{array}{l}\text { Physical } \\
\text { location }\end{array}$ & $\begin{array}{l}\text { Calibration type, } \\
\text { frequency, and } \\
\text { procedure No. }\end{array}$ & $\begin{array}{c}\text { Alarming or } \\
\text { diversion set } \\
\text { points }\end{array}$ \\
\hline $\begin{array}{l}\text { RA-VV-4 } \\
\text { High beta/gamma } \\
\text { radiation alarm } \\
\text { amber light }\end{array}$ & $\begin{array}{l}\text { Local alarm } \\
\text { panel box } \\
\text { assembly }\end{array}$ & $\begin{array}{l}\text { Monthly functional } \\
\text { test: } \\
\text { HPT Proc. } 7.3 .2 \\
\text { PSCP-3-002 }\end{array}$ & $2,000 \mathrm{cpm}$ \\
\hline $\begin{array}{l}\text { RM-VV-2 } \\
\text { Beta/gamma air } \\
\text { monitor }\end{array}$ & $\begin{array}{l}\text { In-cabinet } \\
\text { local mounted } \\
\text { instrument }\end{array}$ & $\begin{array}{l}\text { Monthly overall } \\
\text { calibration: } \\
\text { PSCP-3-002 } \\
\text { Monthly source } \\
\text { check, cleaning } \\
\text { and performance } \\
\text { test: } \\
\text { HPT Proc. } 7.3 .2\end{array}$ & $2,000 \mathrm{cpm}$ \\
\hline $\begin{array}{l}\text { Count-rate meter } \\
\text { (Rescaled) }\end{array}$ & $\begin{array}{l}\text { Beta/gamma air } \\
\text { monitor }\end{array}$ & $\begin{array}{l}\text { Monthly efficiency } \\
\text { test: } \\
\text { HPT Proc. } 7.3 .2 \text { 1- } \\
\text { mo calibration: } \\
\text { PSCP-3-002 }\end{array}$ & $N / A$ \\
\hline $\begin{array}{l}\text { Beta loop } \\
\text { flow regulator } \\
\text { assembly }\end{array}$ & $\begin{array}{l}\text { In-cabinet } \\
\text { 1ocal mounted } \\
\text { equipment }\end{array}$ & $\begin{array}{l}\text { 6-mo lmtd. cal.: } \\
\text { PSCP-6-029 } \\
\text { Daily adjustment: } \\
\text { HPT Proc. 5.2.2.6 }\end{array}$ & $\begin{array}{c}\text { Maintains sample } \\
\text { flow rate of } 2.0 \\
\text { std } \mathrm{ft}^{3} / \mathrm{min}\end{array}$ \\
\hline $\begin{array}{l}\text { PI-VV-2 } \\
\text { Beta/gamma sample } \\
\text { pressure indicator } \\
\text { vacuum gage }\end{array}$ & $\begin{array}{l}\text { In-cabinet } \\
\text { local mounted } \\
\text { instrument }\end{array}$ & $\begin{array}{l}\text { 6-mo cal ibration } \\
\text { PSCP-4-091 }\end{array}$ & $N / A$ \\
\hline $\begin{array}{l}\text { FQI-VV-1 } \\
\text { Gas flowmeter }\end{array}$ & $\begin{array}{l}\text { In-cabinet } \\
\text { local mounted } \\
\text { instrument }\end{array}$ & $\begin{array}{l}\text { 6-mo functional } \\
\text { test } \\
\text { PSCP-4-007 }\end{array}$ & $N / A$ \\
\hline $\begin{array}{l}\text { FI-VV-1 } \\
\text { Record sample } \\
\text { flow-rate indicator }\end{array}$ & $\begin{array}{l}\text { In-cabinet } \\
\text { local mounted } \\
\text { instrument }\end{array}$ & $\begin{array}{l}\text { 6-mo overall } \\
\text { calibration } \\
\text { PSCP-7-001 }\end{array}$ & $N / A$ \\
\hline $\begin{array}{l}\text { FAS-VV-3 } \\
\text { Record sample low- } \\
\text { flow alarm switch }\end{array}$ & $\begin{array}{l}\text { In-cabinet } \\
\text { local mounted } \\
\text { instrument }\end{array}$ & $\begin{array}{l}\text { 6-mo 1mtd. cal: } \\
\text { PSCP-6-029 } \\
\text { Weekly function: } \\
\text { HPT Proc. 5.2.2.6 }\end{array}$ & $\begin{array}{l}\text { Decreasing flow } \\
\text { condition alarms } \\
\text { at } 1.25 \mathrm{ft}^{3} / \mathrm{min}\end{array}$ \\
\hline $\begin{array}{l}\text { Record Sample Loop } \\
\text { Flow regulator } \\
\text { assembly }\end{array}$ & $\begin{array}{l}\text { In-cabinet } \\
\text { local mounted } \\
\text { equipment }\end{array}$ & $\begin{array}{l}\text { 6-mo lmtd. cal.: } \\
\text { PSCP-6-029 } \\
\text { Daily adjustment: } \\
\text { HPT Proc. 5.2.2.6 }\end{array}$ & $\begin{array}{l}\text { Maintains sample } \\
\text { flow rate of } 2.2 \\
\text { std } \mathrm{ft}^{3} / \mathrm{min}\end{array}$ \\
\hline
\end{tabular}


Table 7-1. Monitoring Instrumentation for 242-A Vessel Ventilation System Exhaust Stack 296-A-22. (4 sheets)

\begin{tabular}{|c|c|c|c|}
\hline Instrument type & $\begin{array}{l}\text { Physical } \\
\text { location }\end{array}$ & $\begin{array}{l}\text { Calibration type, } \\
\text { frequency, and } \\
\text { procedure No. }\end{array}$ & $\begin{array}{l}\text { Alarming or } \\
\text { diversion set } \\
\text { points }\end{array}$ \\
\hline $\begin{array}{l}\text { FAL-VV-3A } \\
\text { Low record sample } \\
\text { flow al arm amber } \\
\text { light }\end{array}$ & $\begin{array}{l}\text { Local alarm } \\
\text { panel box } \\
\text { assembly }\end{array}$ & $\begin{array}{l}\text { Weekly functional } \\
\text { test: } \\
\text { HPT Proc. 5.2.2.6 }\end{array}$ & $\begin{array}{l}\text { Decreasing flow } \\
\text { condition alarms } \\
\text { at } 1.25 \mathrm{ft}^{3} / \mathrm{min}\end{array}$ \\
\hline $\begin{array}{l}\text { PI-VV-3 } \\
\text { Record sample } \\
\text { pressure indicator } \\
\text { vacuum gage }\end{array}$ & $\begin{array}{c}\text { In-cabinet } \\
\text { 1ocal mounted } \\
\text { instrument }\end{array}$ & $\begin{array}{l}\text { 6-mo calibration } \\
\text { PSCP-4-091 }\end{array}$ & $N / A$ \\
\hline $\begin{array}{l}\text { Vibrating bell local } \\
\text { alarm }\end{array}$ & $\begin{array}{l}\text { Local alarm } \\
\text { panel box } \\
\text { assembly }\end{array}$ & $\begin{array}{l}\text { Monthly functional } \\
\text { test. } \\
\text { PSCP-3-002,-003 } \\
\text { HPT Proc: } 7.3 .2 \\
\text { Maint. Procedure: } \\
\text { 7-GN-21 }\end{array}$ & $\begin{array}{l}\text { Alarms upon } \\
\text { high radiation }\end{array}$ \\
\hline $\begin{array}{l}\text { Rotating beacon } \\
\text { local alarm }\end{array}$ & $\begin{array}{l}\text { Local alarm } \\
\text { panel box } \\
\text { assembly }\end{array}$ & $\begin{array}{l}\text { Monthly functional } \\
\text { test. } \\
\text { PSCP-3-002,-003 } \\
\text { HPT Proc: } 7.3 .2 \\
\text { Maint. Procedure: } \\
\text { 7-GN-21 }\end{array}$ & $\begin{array}{l}\text { Alarms upon: } \\
\text { - Low sample } \\
\text { flow } \\
\text { - High radiation } \\
\text { - Monitor } \\
\text { failure } \\
\text { - High/low temp. }\end{array}$ \\
\hline $\begin{array}{l}\text { QXA-VV-2 } \\
\text { VV exhaust sample } \\
\text { rack failure alarm }\end{array}$ & $\begin{array}{l}\text { Local alarm } \\
\text { panel box } \\
\text { assembly }\end{array}$ & $\begin{array}{l}\text { Monthly functional } \\
\text { test. } \\
\text { PSCP-3-002,-003 } \\
\text { HPT Proc: } 7.3 .2 \\
\text { Maint. Procedure: } \\
\text { 7-GN-21 }\end{array}$ & $\begin{array}{l}\text { Alarms upon: } \\
\text { - Low sample } \\
\text { flow } \\
\text { - High radiation } \\
\text { - Monitor } \\
\text { failure } \\
\text { - High/low temp. }\end{array}$ \\
\hline $\begin{array}{l}\text { QXS }-V V-1 \\
\text { VV radiation system } \\
\text { failure alarm }\end{array}$ & $\begin{array}{c}\text { Control room: } \\
\text { MCS }\end{array}$ & $\begin{array}{l}\text { Monthly functional } \\
\text { test. } \\
\text { PSCP-3-002,-003 } \\
\text { HPT Proc: } 7.3 .2 \\
\text { Maint. Procedure: } \\
\text { 7-GN-21 }\end{array}$ & $\begin{array}{l}\text { Al arms upon: } \\
\text { - Low sample } \\
\text { flow } \\
\text { - High radiation } \\
\text { - Monitor } \\
\text { failure } \\
\text { - High/low temp. }\end{array}$ \\
\hline Elapsed time meter & $\begin{array}{l}\text { Local monitor } \\
\text { connection box } \\
\text { assembly }\end{array}$ & $\begin{array}{l}\text { Monthly overall } \\
\text { cal ibration. } \\
\text { PSCP-3-002 } \\
\text { HPT Proc: } 7.3 .2\end{array}$ & $\mathrm{~N} / \mathrm{A}$ \\
\hline
\end{tabular}

NOTE: CASS = computer automated surveillance system.

HPT = health physics technician.

MCS = monitor control system. 
each instrument. Operational performance tests and alarm functional tests are conducted on a monthly basis for the CAMs and for the airborne EMS in general. An overall calibration of the CAM units, the remote recorder, and the sample flow instrumentation occurs semiannually. The alarming or diversion set points are also listed in these tables and are described in Section 7.1.1.5 of this FEMP.

7.1.1.7 Building Ventilation Instrumentation. The alpha and beta CAM specifications used in the building ventilation monitoring system are discussed in Section 7.1.1.2. Table 7-2 itemizes other specific instrumentation in the building ventilation exhaust sampling/monitoring systems. Also itemized within this table are the specific locations, calibration frequencies, and related calibration procedures for each instrument. Operational performance tests and alarm functional tests are conducted every 92 days for the CAMs and the airborne EMS in general. An overall calibration of the CAM units, the remote recorder, and the sample flow instrumentation occurs semiannually. The alarming or diversion set points are also listed in these tables and are described in Section 7.1.1.5 of this FEMP.

\subsubsection{Liquid Effluent Streams}

This section describes the specific monitoring instrumentation associated with the used cooling water stream (ACW) and the steam condensate (ASC) at the 242-A Evaporator facility.

7.1.2.1 Components of Liquid Sampling/Monitoring Systems. The liquid monitor systems for the ACW and ASC streams are labeled RC-2 and RC-1, respectively. The monitors are identical in design. A Sodium Iodine (NaI) crystal (detector) and photomultiplier tube are encased in stainless steel. The end of the encased detector is placed within a well. This well is created by the stainless steel canister through which the effluent stream passes. The entire detector system is located within the lead shielded pig. A preamplifier is located on the outside of the pig within the sampler/monitor rack. The remaining instrumentation (i.e., power supply, amplifier, single-channel analyzer, ratemeter) and alarms are located in the control room.

7.1.2.2 Effluent Monitoring System Inspections, Calibrations, and Periodic Testing. The instrumentation within these systems is calibrated periodically to ensure that operation is within the required ranges. Functional tests, cleaning, and required maintenance are also performed. Written procedures are followed in the performance of these tasks. Associated maintenance procedures are found within the 7-GN (generic) series of Hanford Site maintenance procedures. The calibration procedures followed are found in the Component-Based Recall System (CBRS) which is a system established to support the calibration and control of measuring and test equipment (M\&TE). The CBRS program uses a computerized database to document and forecast plant-installed instrument and equipment calibrations and verifications. 
Table 7-2. Monitoring Instrumentation for 242-A Building Ventilation System Exhaust Stack 296-A-21. (5 sheets)

\begin{tabular}{|c|c|c|c|}
\hline Instrument type & Physical location & $\begin{array}{l}\text { Calibration type, } \\
\text { frequency, and } \\
\text { procedure No. }\end{array}$ & $\begin{array}{c}\text { Alarming or } \\
\text { diversion set } \\
\text { points }\end{array}$ \\
\hline $\begin{array}{l}\text { RI-KI-1-2 } \\
\text { Alpha radiation } \\
\text { remote indication } \\
\text { MCS input } \\
1-10,000 \mathrm{cpm}\end{array}$ & $\begin{array}{c}\text { Control room: } \\
\text { - MCS }\end{array}$ & $\begin{array}{l}\text { Weekly operability } \\
\text { inspection: } \\
\text { HPT Proc } 5.2 .2 .6\end{array}$ & $N / A$ \\
\hline $\begin{array}{l}\text { RSH-K1-12 } \\
\text { Bldg. Exh. alpha } \\
\text { radiation high } \\
\text { MCS Input }\end{array}$ & $\begin{array}{c}\text { Control room: } \\
- \text { MCS } \\
\text { - CASS }\end{array}$ & $\begin{array}{l}\text { 92-day functional } \\
\text { test: } \\
\text { TF-FT-680-002 }\end{array}$ & $20 \mathrm{cpn}$ \\
\hline $\begin{array}{l}\text { RA-K1-1-2 } \\
\text { High alpha radiation } \\
\text { alarm amber light }\end{array}$ & $\begin{array}{c}\text { Local al arm panel } \\
\text { box assembly }\end{array}$ & $\begin{array}{l}\text { 92-day functional } \\
\text { test: } \\
\text { TF-FT-680-002 }\end{array}$ & $20 \mathrm{cpm}$ \\
\hline $\begin{array}{l}X A-K 1-1-2 \\
\text { Alpha monitor } \\
\text { failure alarm amber } \\
\text { light }\end{array}$ & $\begin{array}{c}\text { Local alarm panel } \\
\text { box assembly }\end{array}$ & $\begin{array}{l}\text { 92-day functional } \\
\text { test: } \\
\text { TF-FT-680-002 }\end{array}$ & $\begin{array}{l}\text { Alarms upon } \\
\text { failure of alpha } \\
\text { monitoring loop }\end{array}$ \\
\hline $\begin{array}{l}\text { FAS-K1-1 } \\
\text { Flow alarm switch }\end{array}$ & $\begin{array}{l}\text { In-cabinet } \\
\text { 1ocal mounted } \\
\text { instrument }\end{array}$ & $\begin{array}{l}\text { 6-mo lmtd. cal: } \\
\text { PSCP-6-029 } \\
\text { Weekly function: } \\
\text { HPT Proc. 5.2.2.6 }\end{array}$ & $\begin{array}{l}\text { Switches upon } \\
\text { decreasing flow } \\
\text { condition at } \\
1.25 \mathrm{ft}^{3} / \mathrm{min}\end{array}$ \\
\hline $\begin{array}{l}\text { FA-K1-1-2 } \\
\text { Low-flow } \\
\text { alpha alarm } \\
\text { amber light }\end{array}$ & $\begin{array}{c}\text { Local al arm panel } \\
\text { box assembly }\end{array}$ & $\begin{array}{l}\text { Weekly functional } \\
\text { test: } \\
\text { HPT Proc. } 5.2 .2 .6\end{array}$ & $\begin{array}{l}\text { Decreasing flow } \\
\text { condition alarms } \\
\text { at } 1.25 \mathrm{ft}^{3} / \mathrm{min}\end{array}$ \\
\hline $\begin{array}{l}\text { RM-K1-1-2 } \\
\text { Alpha air monitor }\end{array}$ & $\begin{array}{l}\text { In-cabinet } \\
\text { local mounted } \\
\text { instrument }\end{array}$ & $\begin{array}{l}\text { Monthly overall } \\
\text { cal ibration: } \\
\text { PSCP-3-003 } \\
\text { Monthly source } \\
\text { check, cleaning } \\
\text { and performance } \\
\text { test: } \\
\text { HPT Proc. } 7.3 .1\end{array}$ & $20 \mathrm{cpm}$ \\
\hline $\begin{array}{l}\text { Count-rate meter } \\
\text { (Rescaled) }\end{array}$ & Alpha air monitor & $\begin{array}{l}\text { Monthly efficiency } \\
\text { test: HPT Proc. } \\
\text { 7.3.i } \\
\text { Monthly cal: } \\
\text { PSCP-3-003 }\end{array}$ & $N / A$ \\
\hline
\end{tabular}


Table 7-2. Monitoring Instrumentation for 242-A Building Ventilation System Exhaust Stack 296-A-21. (5 sheets)

\begin{tabular}{|c|c|c|c|}
\hline Instrument type & Physical location & $\begin{array}{l}\text { Calibration type, } \\
\text { frequency, and } \\
\text { procedure No. }\end{array}$ & $\begin{array}{c}\text { Alarming or } \\
\text { diversion set } \\
\text { points }\end{array}$ \\
\hline $\begin{array}{l}\text { Alpha loop flow } \\
\text { regulator assembly }\end{array}$ & $\begin{array}{l}\text { In-cabinet } \\
\text { local mounted } \\
\text { equipment }\end{array}$ & $\begin{array}{l}\text { 6-mo lmtd cal.: } \\
\text { PSCP-6-029 } \\
\text { Daily adjustment: } \\
\text { HPT Proc. } 5.2 .2 .6\end{array}$ & $\begin{array}{l}\text { Maintains sample } \\
\text { flow rate of } \\
2.0 \text { std } \mathrm{ft}^{3} / \mathrm{min}\end{array}$ \\
\hline $\begin{array}{l}\text { PI-KI-1-2 } \\
\text { Alpha CAM } \\
\text { pressure indicator }\end{array}$ & $\begin{array}{l}\text { In-cabinet } \\
\text { local mounted } \\
\text { instrument }\end{array}$ & $\begin{array}{l}\text { 6-mo functional } \\
\text { test: } \\
7-\text { GN-38 } \\
\text { PSCP-4-006 }\end{array}$ & $N / A$ \\
\hline $\begin{array}{l}\text { RI-KI-1-1 } \\
\text { Bldg. exhaust } \\
\text { beta/gamma radn. } \\
\text { MCS input } \\
\text { Range: } 10-99999 \mathrm{cpm}\end{array}$ & $\begin{array}{c}\text { Control room: } \\
\text { - MCS }\end{array}$ & $\begin{array}{l}\text { Weekly operability } \\
\text { inspection: } \\
\text { HPT Proc. } 5.2 .2 .6\end{array}$ & $N / A$ \\
\hline $\begin{array}{l}\text { RSH-K1-11 } \\
\text { Bldg. exhaust } \\
\text { beta/gamma radn. } \\
\text { hign } \\
\text { MCS al arm input }\end{array}$ & $\begin{array}{c}\text { Control room: } \\
- \text { MCS } \\
\text { - CASS }\end{array}$ & $\begin{array}{l}\text { 92-day functional } \\
\text { test: } \\
\text { TF-FT-680-002 }\end{array}$ & $2,000 \mathrm{cpm}$ \\
\hline $\begin{array}{l}\text { RA-Kl-1-1 } \\
\text { High beta/gamma } \\
\text { radiation alarm } \\
\text { amber light }\end{array}$ & $\begin{array}{c}\text { Local al arm panel } \\
\text { box assembly }\end{array}$ & $\begin{array}{l}\text { 92-day functional } \\
\text { test: } \\
\text { TF-FT-680-002 }\end{array}$ & $2,000 \mathrm{cpm}$ \\
\hline $\begin{array}{l}X A-K 1-1-1 \\
\text { Beta/gamma monitor } \\
\text { failure alarm amber } \\
\text { light }\end{array}$ & $\begin{array}{c}\text { Local alarm panel } \\
\text { box assembly }\end{array}$ & $\begin{array}{l}\text { 92-day functional } \\
\text { test: } \\
\text { TF-FT-680-002 }\end{array}$ & $\begin{array}{l}\text { Alarms upon } \\
\text { failure of beta } \\
\text { monitoring loop }\end{array}$ \\
\hline $\begin{array}{l}\text { FAS-K1-2 } \\
\text { Flow alarm switch }\end{array}$ & $\begin{array}{l}\text { In-cabinet } \\
\text { local mounted } \\
\text { instrument }\end{array}$ & $\begin{array}{l}\text { 6-mo imtd. cal : } \\
\text { PSCP-6-029 } \\
\frac{\text { Week ly function: }}{\text { HPT Proc. 5.2.2.6 }}\end{array}$ & $\begin{array}{l}\text { Switches upon } \\
\text { low flow } \\
\text { condition of } \\
1.25 \mathrm{ft}^{3} / \mathrm{min}\end{array}$ \\
\hline $\begin{array}{l}\text { FA-Kl-1-1 } \\
\text { Low-flow } \\
\text { beta/gamma alarm } \\
\text { amber light }\end{array}$ & $\begin{array}{c}\text { Local alarm panel } \\
\text { box assembly }\end{array}$ & $\begin{array}{l}\text { Weekly functional } \\
\text { test: } \\
\text { HPT Proc. 5.2.2.6 }\end{array}$ & $\begin{array}{l}\text { Decreasing flow } \\
\text { condition alarms } \\
\text { at } 1.25 \mathrm{ft}^{3} / \mathrm{min}^{2}\end{array}$ \\
\hline
\end{tabular}


Table 7-2. Monitoring Instrumentation for 242-A Building Ventilation System Exhaust Stack 296-A-21. (5 sheets)

\begin{tabular}{|c|c|c|c|}
\hline Instrument type & Physical location & $\begin{array}{l}\text { Cal ibration type, } \\
\text { frequency, and } \\
\text { procedure No. }\end{array}$ & $\begin{array}{c}\text { Alarming or } \\
\text { diversion set } \\
\text { points }\end{array}$ \\
\hline $\begin{array}{l}\text { RM-K1-2 } \\
\text { Beta/gamma } \\
\text { air monitor }\end{array}$ & $\begin{array}{l}\text { In-cabinet } \\
\text { local mounted } \\
\text { instrument }\end{array}$ & $\begin{array}{l}\text { Monthly overall } \\
\text { cal ibration: } \\
\text { PSCP-3-002 } \\
\text { Monthly source } \\
\text { check, cleaning } \\
\text { and performance } \\
\text { test: } \\
\text { HPT Proc. } 7.3 .2\end{array}$ & $2,000 \mathrm{cpm}$ \\
\hline $\begin{array}{l}\text { Count-rate meter } \\
\text { (Rescaled) }\end{array}$ & $\begin{array}{l}\text { Beta/gamma air } \\
\text { monitor }\end{array}$ & $\begin{array}{l}\text { Monthly overall } \\
\text { cal ibration: } \\
\text { PSCP-3-002 } \\
\text { Monthly limited } \\
\text { cal ibration: } \\
\text { HPT Proc. } 7.3 .2\end{array}$ & $\mathrm{~N} / \mathrm{A}$ \\
\hline $\begin{array}{l}\text { Beta/gamma loop flow } \\
\text { regulator assembly }\end{array}$ & $\begin{array}{l}\text { In-cabinet } \\
\text { local mounted } \\
\text { equipment }\end{array}$ & $\begin{array}{l}\text { 6-mo lmtd. cal.: } \\
\text { PSCP-6-029 } \\
\text { Daily adjustment: } \\
\text { HPT Proc. 5.2.2.6 }\end{array}$ & $\begin{array}{l}\text { Maintains sample } \\
\text { flow rate of } \\
2.0 \text { std } \mathrm{ft}^{3} / \mathrm{min}\end{array}$ \\
\hline $\begin{array}{l}\text { PI-KI-1-1 } \\
\text { Beta/gamma CAM } \\
\text { pressure indicator }\end{array}$ & $\begin{array}{l}\text { In-cabinet } \\
\text { local mounted } \\
\text { instrument }\end{array}$ & $\begin{array}{l}\text { 6-month } \\
\text { calibration: } \\
\text { PSCP-4-006 }\end{array}$ & $N / A$ \\
\hline $\begin{array}{l}\text { FQI-KI-1 } \\
\text { Gas flowmeter } \\
\text { (totalizer) }\end{array}$ & $\begin{array}{l}\text { In-cabinet } \\
\text { local mounted } \\
\text { instrument }\end{array}$ & $\begin{array}{l}\text { 6-mo functional } \\
\text { test: } \\
\text { PSCP-4-007 }\end{array}$ & $N / A$ \\
\hline $\begin{array}{l}\text { FI-KI-1-1 } \\
\text { Sampler flow- } \\
\text { rate indicator }\end{array}$ & $\begin{array}{l}\text { In-cabinet } \\
\text { local mounted } \\
\text { instrument }\end{array}$ & $\begin{array}{l}\text { 6-month overall } \\
\text { calibration: } \\
\text { PSCP-7-001 }\end{array}$ & $N / A$ \\
\hline $\begin{array}{l}\text { FA-Kl-1-3 } \\
\text { Low record sample } \\
\text { flow alarm amber } \\
\text { light }\end{array}$ & $\begin{array}{c}\text { Local al arm panel } \\
\text { box assembly }\end{array}$ & $\begin{array}{l}\text { Weekly functional } \\
\text { test: } \\
\text { HPT Proc 5.2.2.6 }\end{array}$ & $\begin{array}{l}\text { Decreasing flow } \\
\text { condition alarms } \\
\text { at } 1.25 \mathrm{ft}^{3} / \mathrm{min}\end{array}$ \\
\hline $\begin{array}{l}\text { FAS-K1-3 } \\
\text { Flow alarm switch }\end{array}$ & $\begin{array}{l}\text { In-cabinet } \\
\text { local mounted } \\
\text { instrument }\end{array}$ & $\begin{array}{l}\text { 6-month lmtd. cal: } \\
\text { PSCP-6-029 } \\
\text { Weekly function: } \\
\text { HPT Proc 5.2.2.6 }\end{array}$ & $\begin{array}{l}\text { Switches upon } \\
\text { decreasing flow } \\
\text { condition at } \\
1.25 \mathrm{ft}^{3} / \mathrm{min} \\
\end{array}$ \\
\hline $\begin{array}{l}\text { Record sample loop } \\
\text { flow regulator } \\
\text { assembly }\end{array}$ & $\begin{array}{l}\text { In-cabinet } \\
\text { local mounted } \\
\text { equipment }\end{array}$ & $\begin{array}{l}\text { 6-mo lmtd. cal.: } \\
\text { PSCP-6-029 } \\
\text { Daily adjustment: } \\
\text { HPT Proc. 5.2.2.6 }\end{array}$ & $\begin{array}{l}\text { Maintains sample } \\
\text { flow rate of } \\
2.2 \text { std } \mathrm{ft}^{3} / \mathrm{min}\end{array}$ \\
\hline
\end{tabular}


Table 7-2. Monitoring Instrumentation for 242-A Building Ventilation System Exhaust Stack 296-A-21. (5 sheets)

\begin{tabular}{|c|c|c|c|}
\hline Instrument type & Physical location & $\begin{array}{l}\text { Calibration type, } \\
\text { frequency, and } \\
\text { procedure No. }\end{array}$ & $\begin{array}{l}\text { Alarming or } \\
\text { diversion set } \\
\text { points }\end{array}$ \\
\hline $\begin{array}{l}\text { PI-K1-1-2 } \\
\text { Pressure indicator } \\
\text { vacuum gage }\end{array}$ & $\begin{array}{l}\text { In-cabinet } \\
\text { local mounted } \\
\text { instrument }\end{array}$ & $\begin{array}{l}\text { 6-mo cal ibration } \\
\text { PSCP-4-091 }\end{array}$ & $N / A$ \\
\hline $\begin{array}{l}\text { QXA-K1-1 } \\
\text { Bldg. exhaust radn. } \\
\text { monitor system } \\
\text { trouble alarm }\end{array}$ & $\begin{array}{c}\text { Control Room: } \\
\text { - MCS }\end{array}$ & $\begin{array}{l}\text { 92-day functional } \\
\text { test. } \\
\text { TF-FT-680-002 }\end{array}$ & $\begin{array}{l}\text { General sampler } \\
\text { system failure }\end{array}$ \\
\hline $\begin{array}{l}\text { Vibrating bell } \\
\text { local al arm }\end{array}$ & $\begin{array}{c}\text { Local al arm panel } \\
\text { box assembly }\end{array}$ & $\begin{array}{l}\text { 92-day functional } \\
\text { test: } \\
\text { TF-FT-680-002 }\end{array}$ & $\begin{array}{l}\text { Alarms upon } \\
\text { high radiation }\end{array}$ \\
\hline $\begin{array}{l}\text { Rotating beacon } \\
\text { local alarm }\end{array}$ & $\begin{array}{c}\text { Local al arm panel } \\
\text { box assembly }\end{array}$ & $\begin{array}{l}\text { 92-day functional } \\
\text { test: } \\
\text { TF-FT-680-002 }\end{array}$ & $\begin{array}{l}\text { Alarms upon: } \\
\text { - Low sample } \\
\text { flow } \\
\text { - High } \\
\text { radiation } \\
\text { - Monitor } \\
\text { failure } \\
\text { - High/low } \\
\text { temp. }\end{array}$ \\
\hline $\begin{array}{l}\text { Thermostat } \\
\text { heat trace }\end{array}$ & $\begin{array}{l}\text { In-cabinet } \\
\text { local mounted } \\
\text { instrument }\end{array}$ & $\begin{array}{l}\text { 1-mo Functional } \\
\text { Test: } \quad 7-G N-21\end{array}$ & $N / A$ \\
\hline $\begin{array}{l}\text { Thermostat preset } \\
\text { temperature switch }\end{array}$ & $\begin{array}{l}\text { In-cabinet } \\
\text { local mounted } \\
\text { instrument }\end{array}$ & $\begin{array}{l}\text { 1-mo Functional } \\
\text { Test: } \\
\text { PSCP-3-002,-003 } \\
\text { 7-GN-021 } \\
\text { Calibration: } \\
\text { PSCP-6-099 }\end{array}$ & $\begin{array}{lllll}\text { Open } & 0 & 85 & \pm 5 & \circ \\
\text { Close } & 0 & 95 & \pm 5 & \circ\end{array}$ \\
\hline $\begin{array}{l}\text { Thermostat preset } \\
\text { temperature switch }\end{array}$ & $\begin{array}{l}\text { In-cabinet } \\
\text { local mounted } \\
\text { instrument }\end{array}$ & $\begin{array}{l}\text { 1-mo Functional } \\
\text { Test: } \\
\text { PSCP-3-002,-003 } \\
\text { 7-GN-021 } \\
\text { Cal ibration: } \\
\text { PSCP-6-099 }\end{array}$ & $\begin{array}{lllll}\text { Open } & 0 & 75 & \pm 5 & \circ \\
\text { Close } & 0 & 65 & \pm 5 & \\
\end{array}$ \\
\hline
\end{tabular}


Table 7-2. Monitoring Instrumentation for 242-A Building Ventilation System Exhaust Stack 296-A-21. (5 sheets)

\begin{tabular}{|c|c|c|c|}
\hline Instrument type & Physical location & $\begin{array}{l}\text { Calibration type, } \\
\text { frequency, and } \\
\text { procedure No. }\end{array}$ & $\begin{array}{c}\text { Alarming or } \\
\text { diversion set } \\
\text { points }\end{array}$ \\
\hline $\begin{array}{l}\text { TA-K1-1 } \\
\text { High/low cabinet } \\
\text { temperature alarm } \\
\text { amber light }\end{array}$ & $\begin{array}{c}\text { Local alarm panel } \\
\text { box assembly }\end{array}$ & $\begin{array}{l}\text { 1-mo Functional } \\
\text { Test: } \\
\text { PSCP-3-002,-003 }\end{array}$ & $\begin{array}{l}\text { Alarms upon } \\
\text { cabinet } \\
\text { temperatures } \\
\text { above } 125^{\circ} \mathrm{F} \text { or } \\
\text { below } 55{ }^{\circ} \mathrm{F}\end{array}$ \\
\hline $\begin{array}{l}\text { TS HIGH/S1 } \\
\text { Thermostat preset } \\
\text { temperature switch }\end{array}$ & $\begin{array}{l}\text { Local monitor } \\
\text { connection box } \\
\text { assembly }\end{array}$ & $\begin{array}{l}\text { 1-mo Functional } \\
\text { Test: } \\
\text { PSCP-3-002,-003 } \\
\text { 7-GN-21 } \\
\text { Calibration: } \\
\text { PSCP-6-099 }\end{array}$ & $\begin{array}{l}\text { Thermostat } \\
\text { sensor contact } \\
\text { open on rising } \\
\text { temperature. } \\
\text { N.0. above } \\
125 \text { o F } \\
\text { N.C. below } \\
115 \text { o F }\end{array}$ \\
\hline $\begin{array}{l}\text { TS LOW/S2 } \\
\text { Thermostat preset } \\
\text { temperature switch }\end{array}$ & $\begin{array}{l}\text { Local monitor } \\
\text { connection box } \\
\text { assembly }\end{array}$ & $\begin{array}{l}\text { 1-mo Functional } \\
\text { Test: } \\
\text { PSCP-3-002,-003 } \\
\text { 7-GN-21 } \\
\text { Calibration: } \\
\text { PSCP-6-099 }\end{array}$ & $\begin{array}{l}\text { Thermostat } \\
\text { sensor contact } \\
\text { closed on rising } \\
\text { temp. } \\
\text { N.C. above } 65^{\circ} \mathrm{F} \\
\text { N.O. below } 45^{\circ} \mathrm{F}\end{array}$ \\
\hline $\begin{array}{l}\text { CVT-K1-2 } \\
\text { Bldg. exh. pneumatic } \\
\text { electric converter }\end{array}$ & $\begin{array}{l}\text { HVAC Building } \\
\text { exhaust stack }\end{array}$ & $\begin{array}{l}\text { 12-mo overall } \\
\text { calibration } \\
\text { PSCP-1-004 }\end{array}$ & $N / A$ \\
\hline $\begin{array}{l}\text { CVT-K1-1 } \\
\text { Bldg. exh. pneumatic } \\
\text { electric converter }\end{array}$ & $\begin{array}{l}\text { HVAC Building } \\
\text { exhaust }\end{array}$ & $\begin{array}{l}\text { 12-mo overall } \\
\text { cal ibration: } \\
\text { PSCP-1-004 }\end{array}$ & $N / A$ \\
\hline $\begin{array}{l}\text { TI-KI-2 } \\
\text { Bldg. exh. stack } \\
\text { temperature } \\
\text { indicator }\end{array}$ & $\begin{array}{c}\text { Control room: } \\
\text { - MCS }\end{array}$ & $N / A$ & $N / A$ \\
\hline Elapsed time meter & $\begin{array}{l}\text { Local monitor } \\
\text { connection box } \\
\text { assembly }\end{array}$ & $\begin{array}{l}\text { Monthly overall } \\
\text { cal ibration: } \\
\text { PSCP-3-002 } \\
\text { HPT Proc. 7.3.2 }\end{array}$ & $N / A$ \\
\hline
\end{tabular}

NOTE: $\quad$ CAM = continuous air monitor.

CASS = computer automated surveillance system.

cpm = counts per minute.

HPT = health physics technician.

HVAC = heating, ventilating, and air conditioning.

MCS = monitor control system.

N.C. = normally closed.

N.O. = normally opened. 
Rockwell Hanford Operations supporting document SD-SQA-TI-003, Liquid Effluent Monitor Calibration for the 242-A Evaporator (RHO 1985), presents the technical information corcerning calibration of the licjuid effluent monitors at the 242-A Evaporator. The calibration consists of obtaining a correlationrelating monitor reading to radioactivity concentrations. This is accomplished by making use of sealed sample canisters containing NBSequivalent traceable solutions of ${ }^{137} \mathrm{Cs}$, which allows for maintenance of identical source-to-detector geometry. The correlation curve is plotted as activity (counts per second) versus concentration of calibration standards (microcuries of ${ }^{137} \mathrm{Cs} / \mathrm{mL}$ ).

Functional tests are conducted periodically and calibration of the radiation monitoring system are corducted annually. Operability verification is conducted daily on the steam condensate system. Alarms are tested and set points adjusted monthly. Periodically, system performance is evaluated based in regulatory limits. Applicable procedures and their frequencies are listed in Tables 7-3 and 7-4.

7.1.2.3 Effluent Monitoring Systems Alarming/Diversion Set Points. Limits for radionuclide releases in the steam condensate and cooling water effluent streams are specified in 0SD-T-151-00012, Operating Specifications for the Operation of the 242-A Evaporator-Crystallizer (WHC 1988b). Radionuclide releases up to the specification limits are set to meet the requirements of WHC-CM-7-5, Environmental Compliance Manual (Parts A, B, F and Appendix A) (WHC 1992i), and are considered safe for the environment. The maximum instantaneous concentration limit for ${ }^{137} \mathrm{Cs}$ is $1.5 \times 10^{-i} \mu \mathrm{Ci} / \mathrm{mL}$. As discussed in Section 7.1.2.2., the liquid monitor systems at the facility are calibrated using a ${ }^{137} \mathrm{Cs}$ source. Reference to the detector calibration correlation curve found in RHO-QA-TI-003, Liquid Effluent Monitor Calibration for the 242-A Evaporator (RHO 1985), shows that the limit corresponds to a radioactivity of 800 cps.

The monitor on the steam condensate stream is set to alarm at $480 \mathrm{cps}$ on increasing radiation. This stream is also diverted to the evaporator feed tank (TK-102-AW) should activity levels reach this threshold.

The monitor on the used cooling water stream is set to alarm at $7.5 \mathrm{cps}$ on increasing radiation. The cooling water sampling and monitoring system, $\mathrm{RC}-2$, has no diversion capabilities, thus high levels of radiation detected in this stream require immediate evaporator shutdown.

7.1.2.4 Cooling Water Instrumentation. Radiation information is monitored on the MCS by radiation indicator RI-RC2-1. A count-rate meter is self-contained with a range of 10 to $1.0 \times 10^{+6} \mathrm{cpm}( \pm 2.0 \%)$ on an adjustable linear or logarithmic scale. Radiation alarms are activated at $7.5 \mathrm{cps}\left(10^{2} \mathrm{scale}\right)$ on increasing radiation.

Table 7-3 displays the instrumentation related to the sampliing/monitoring systems for the used raw-water stream. Instrument locations, calibration frequencies, and alarming or diversion set points ire included in this matrix. Drawing No. H-2-98994 (Figure 7-2) is an instrument flow diagram for the used raw-water system. 
Table 7-3. Monitoring Instrumentation for 242-A Evaporator Used Raw Water System Waste Stream. (Hanford Site Stream Code ACW) (3 sheets)

\begin{tabular}{|c|c|c|c|}
\hline Instrument type & Physical location & $\begin{array}{c}\text { Calibration type, } \\
\text { frequency, and } \\
\text { procedure No. }\end{array}$ & $\begin{array}{l}\text { Alarming or } \\
\text { diversion } \\
\text { set points }\end{array}$ \\
\hline $\begin{array}{l}\text { FIAS-RC2-1 used } \\
\text { raw-water } \\
\text { sampler/monitor } \\
\text { low-flow indicator } \\
\text { alarm switch }\end{array}$ & $\begin{array}{l}\text { 2nd level of } \\
\text { condenser room } \\
\mathrm{RC}-2 \text { sample and } \\
\text { monitor rack }\end{array}$ & $\begin{array}{l}\text { 12-mo limited } \\
\text { calibration } \\
\text { Maint: } 7-G N-38 \\
\text { Cal: PSCP-1-062 }\end{array}$ & $\begin{array}{l}\text { Decreasing } \\
\text { cooling } \mathrm{H}_{2} 0 \\
\text { sample flow-rate } \\
\text { activates switch } \\
\text { at } 0.3 \mathrm{gal} / \mathrm{min}\end{array}$ \\
\hline $\begin{array}{l}\text { FSL-RC2-1 used } \\
\text { raw-water } \\
\text { sampler/monitor } \\
\text { low-flow rate } \\
\text { (MCS Input) }\end{array}$ & $\begin{array}{c}\text { Control room: } \\
\text { (MCS) }\end{array}$ & $N / A$ & $\begin{array}{l}<0.3 \mathrm{gal} / \mathrm{min} \\
\text { cooling } \mathrm{H}_{2} \mathrm{O} \\
\text { sample flow }\end{array}$ \\
\hline $\begin{array}{l}\mathrm{FE}-\mathrm{RC2}-1 \text { Cooling } \\
\mathrm{H}_{2} \mathrm{O} \text { flow element on } \\
\text { used raw-water line } \\
\text { fabricated } \\
\left(0-200 \text { in. } \mathrm{H}_{2} \mathrm{O}\right)\end{array}$ & $\begin{array}{l}\text { 2nd Level of } \\
\text { condenser room }\end{array}$ & $\begin{array}{l}\text { Pre-calibration } \\
\text { Certification. } \\
\text { Maint: } 7-G N-38\end{array}$ & $N / A$ \\
\hline $\begin{array}{l}\mathrm{FT}-\mathrm{RC} 2-1 \text { Cooling } \\
\mathrm{H}_{2} \mathrm{O} \text { flow to } \\
216-\mathrm{B} \text { Pond } \\
\text { Elec. Diff. } \\
\text { pressure } \\
\text { transmitter } \\
(0-4,000 \mathrm{gal} / \mathrm{min})\end{array}$ & $\begin{array}{l}\text { 3rd Level of } \\
\text { condenser room }\end{array}$ & $\begin{array}{l}\text { 12-mo overall } \\
\text { calibration: } \\
\text { PSCP-6-188 } \\
\text { Maint: } 7-G N-38\end{array}$ & $N / A$ \\
\hline $\begin{array}{l}\text { FI-RC2-1 used } \\
\text { raw-water flow to } \\
216-B \text { Pond flow } \\
\text { indicator MCS Input } \\
\text { Range: } \\
0-4,000 \mathrm{gal} / \mathrm{min}\end{array}$ & $\begin{array}{c}\text { Control Room: } \\
\bullet \text { MCS }\end{array}$ & $N / A$ & $N / A$ \\
\hline $\begin{array}{l}\text { RE- } R C 2-1 \text { Cooling } \\
\text { water radiation } \\
\text { clement } \\
\text { Range: } 0 \text { to } 10 \mathrm{cps}\end{array}$ & $\begin{array}{l}\text { 2nd level of } \\
\text { condenser room in } \\
\text { RC-2 sample and } \\
\text { monitor rack }\end{array}$ & $\begin{array}{l}\text { Radioactive source } \\
\text { alignment: } \\
6-\text { TF-045 } \\
\text { 12-mo overal1 cal: } \\
\text { PSCP-3-102 } \\
\text { Maint: 7-GN-38 }\end{array}$ & $\begin{array}{l}\text { Alarm High: } \\
7.5 \text { cps above } \\
\text { background }\end{array}$ \\
\hline $\begin{array}{l}\text { RX-RC2-1 } \\
\text { Preamplifier } \\
\text { Range: } \\
0-50 \text { cps }\end{array}$ & $\begin{array}{l}\text { 2nd level of } \\
\text { condenser room in } \\
\text { RC-2 sample and } \\
\text { monitor rack }\end{array}$ & $\begin{array}{l}\text { 6-mo funcitional } \\
\text { check: job card }\end{array}$ & $N / A$ \\
\hline
\end{tabular}


Table 7-3. Monitoring Instrumentation for 242-A Evaporator Used Raw Water System Waste Stream. (Hanford Site Stream Code ACW) (3 sheets)

\begin{tabular}{|c|c|c|c|}
\hline Instrument type & Physical location & $\begin{array}{l}\text { Calibration type, } \\
\text { frequency, and } \\
\text { procedure No. }\end{array}$ & $\begin{array}{l}\text { Alarming or } \\
\text { diversion } \\
\text { set points }\end{array}$ \\
\hline $\begin{array}{l}\text { RX-RC2-2 } \\
\text { amplifier }\end{array}$ & Control room & $\begin{array}{l}\text { 12-mo overall cal: } \\
\text { PSCP-3-102 }\end{array}$ & $N / A$ \\
\hline $\begin{array}{l}\text { RX-RC2-3 } \\
\text { Pulse height } \\
\text { analyzer }\end{array}$ & Control room & $\begin{array}{l}\text { 6-mo functional } \\
\text { test: PSCP-3-017 } \\
\text { 12-mo overall cal: } \\
\text { PSCP-3-102 }\end{array}$ & $N / A$ \\
\hline $\begin{array}{l}\text { RXAS-RC2-1 } \\
\text { CoOl ing } \mathrm{H}_{2} \mathrm{O} \text { fail } \\
\text { alarm switch }\end{array}$ & Control room & $\begin{array}{l}\text { 6-mo functional } \\
\text { test: job card }\end{array}$ & $\begin{array}{l}\text { Switches upon } \\
\text { failure of } \\
\text { radiation } \\
\text { monitoring } \\
\text { system }\end{array}$ \\
\hline $\begin{array}{l}\text { RXS-RC2-1 } \\
\text { URW radiation } \\
\text { system failure } \\
\text { alarm }\end{array}$ & $\begin{array}{c}\text { Control room } \\
\text { MCS }\end{array}$ & $\begin{array}{l}\text { 6-mo functional } \\
\text { test: job card }\end{array}$ & $N / A$ \\
\hline $\begin{array}{l}\text { RIAS-RC2-1 } \\
\text { Cool ing } \mathrm{H}_{2} \mathrm{O} 1 \mathrm{in} / 1 \mathrm{og} \\
\text { count-rate meter } \\
\text { Range: } 0-100 \%\end{array}$ & $\begin{array}{l}\text { Radiation cabinet } \\
\text { Control room }\end{array}$ & $\begin{array}{l}\text { Monthly functional } \\
\text { test: job card } \\
\text { 12-mo overall cal: } \\
\text { PSCP-3-102 }\end{array}$ & $\begin{array}{l}\text { Activates at } \\
7.5 \text { cps on } \\
\text { increasing } \\
\text { radiation }\end{array}$ \\
\hline $\begin{array}{l}\text { RXA-RC2-1 } \\
\text { Radiation alarm }\end{array}$ & Control room & $\begin{array}{l}\text { Monthly functional } \\
\text { test: job card }\end{array}$ & $\begin{array}{l}\text { Alarm high: } \\
7.5 \mathrm{cps}\end{array}$ \\
\hline $\begin{array}{l}\text { RI-RC2-1 } \\
\text { Used raw-water } \\
\text { (URW) sampler } \\
\text { radiation MCS input }\end{array}$ & $\begin{array}{c}\text { Control room } \\
\text { MCS }\end{array}$ & $\begin{array}{l}\text { Monthly functional } \\
\text { test: job card }\end{array}$ & $\begin{array}{l}\text { Alarm low: } \\
\text { inactive }\end{array}$ \\
\hline $\begin{array}{l}\text { RSH-RC2-1 } \\
\text { URW high radiation } \\
\text { alarm }\end{array}$ & $\begin{array}{l}\text { Monitor control } \\
\text { system (MCS) }\end{array}$ & $\begin{array}{l}\text { Monthly functional } \\
\text { test: job card }\end{array}$ & $\begin{array}{l}\text { Alarm high: } \\
7.5 \mathrm{cps}\end{array}$ \\
\hline $\begin{array}{l}\text { RAH-RC2-1 } \\
\text { URW high radiation } \\
\text { alarm }\end{array}$ & CASS & $\begin{array}{l}\text { Monthly functional } \\
\text { test: job card }\end{array}$ & $\begin{array}{l}\text { Alarm High: } \\
7.5 \mathrm{cps}\end{array}$ \\
\hline $\begin{array}{l}\text { PT-ECl-9 } \\
\text { URW Outlet pressure } \\
\text { transmitter } \\
\text { (0 to } 1201 \mathrm{bf} / \mathrm{in}^{2}{ }^{2} \text { ) } \\
\text { (gauge) }\end{array}$ & $\begin{array}{l}\text { 1st Level of } \\
\text { condenser room }\end{array}$ & $\begin{array}{l}\text { 12-mo calibration } \\
\text { PSCP-6-196 } \\
\text { Maint: 7-GN-38 }\end{array}$ & $N / A$ \\
\hline
\end{tabular}


Table 7-3. Monitoring Instrumentation for 242-A Evaporator Used Raw Water System Waste Stream. (Hanford Site Stream Code ACW) (3 sheets)

\begin{tabular}{|c|c|c|c|}
\hline Instrument type & Physical location & $\begin{array}{l}\text { Calibration type, } \\
\text { frequency, and } \\
\text { procedure No. }\end{array}$ & $\begin{array}{l}\text { Alarming or } \\
\text { diversion } \\
\text { set points }\end{array}$ \\
\hline $\begin{array}{l}\text { PI-RC2-1 } \\
\text { URW sampler air } \\
\text { sparge pressure } \\
\text { indicator } \\
0 \text {-30 } 1 \mathrm{bf} / \text { in. }^{2} \\
\text { (gauge) }\end{array}$ & $\begin{array}{l}\text { 2nd Level of } \\
\text { condenser room }\end{array}$ & $\begin{array}{l}\text { 12.-mo maintenance: } \\
7-G N-38\end{array}$ & Local indication \\
\hline $\begin{array}{l}\text { PI-RC2-2 } \\
\text { URW sample air } \\
\text { supply pressure } \\
\text { indicator } \\
0-301 \mathrm{bf} / \mathrm{in}^{2} \\
\text { (gauge) }\end{array}$ & $\begin{array}{l}\text { 2nd level of } \\
\text { condenser room }\end{array}$ & $\begin{array}{l}\text { 12-mo maintenance: } \\
7-G N-38\end{array}$ & Local indication \\
\hline $\begin{array}{l}\text { YS }-\mathrm{RC} 2-6 \\
\mathrm{RC} 2 \text { radiation } \\
\text { bypass switch }\end{array}$ & MCS & NA & $\begin{array}{l}\text { MCS Primary } \\
\text { alarm }\end{array}$ \\
\hline $\begin{array}{l}\text { Stationary } \\
\text { composite sampler }\end{array}$ & $\begin{array}{l}\text { 2nd Level of } \\
\text { condenser room in } \\
\mathrm{RC}-2 \text { sample and } \\
\text { monitor rack }\end{array}$ & PSCP-3-029 & $N / A$ \\
\hline $\begin{array}{l}\text { JC-RC2-1 } \\
\text { Power controller }\end{array}$ & Control room & $\begin{array}{l}\text { 12-mo overal1 cal: } \\
\text { PSCP-3-102 }\end{array}$ & $N / A$ \\
\hline
\end{tabular}

NOTE: CASS $=$ computer automated surveillance system.

cps = counts per second .

MCS = monitor control system

URW = used raw water. 
Table 7-4. Monitoring Instrumentation for 242-A Steam Condensate System Waste Stream. (Hanford Site Stream Code ASC) (3 sheets)

\begin{tabular}{|c|c|c|c|}
\hline Instrument type & $\begin{array}{l}\text { Physical } \\
\text { location }\end{array}$ & $\begin{array}{l}\text { Alarming or } \\
\text { diversion set } \\
\text { points }\end{array}$ & $\begin{array}{l}\text { Calibration type, } \\
\text { frequency, and } \\
\text { procedure number }\end{array}$ \\
\hline $\begin{array}{l}\text { FIAS-RC1-1 } \\
\text { Steam condensate } \\
\text { rad. monitor } \\
\text { low flow } \\
\text { alarm switch }\end{array}$ & $\begin{array}{l}\text { lst floor of } \\
\text { condenser room }\end{array}$ & $\begin{array}{l}\text { Alarms upe: low- } \\
\text { flow condition of } \\
0.30 \mathrm{gal} / \mathrm{min}\end{array}$ & $\begin{array}{l}\text { Limited } \\
\text { calibration: } \\
\text { (12-mo) } \\
\text { PSCP-1-062 }\end{array}$ \\
\hline $\begin{array}{l}\text { FSL-RCI-1 } \\
\text { SC sampler flow } \\
\text { low alarm }\end{array}$ & $\begin{array}{c}\text { Control room } \\
\text { - MCS }\end{array}$ & $\begin{array}{l}\text { Alarms upon low- } \\
\text { flow condition of } \\
0.30 \mathrm{gal} / \mathrm{min}\end{array}$ & $N / A$ \\
\hline $\begin{array}{l}\text { RE-RC1-1 } \\
\text { Steam condensate } \\
\text { rad. monitor }\end{array}$ & $\begin{array}{l}\text { 1st floor of } \\
\text { condenser room }\end{array}$ & $\begin{array}{l}\text { Alarm: } \\
\text { High radiation at } \\
80 \text { cps } \\
\text { Diversion: } \\
\text { SC diverted to } \\
\text { feed tank 102-AW }\end{array}$ & $\begin{array}{l}\text { Daily verification: } \\
\text { TF-OR-OFR-001 } \\
\text { 92-day functional } \\
\text { test: } \\
\text { TF-FT-680-018 } \\
\text { 12-mo 100p cal: } \\
\text { TF-CC-690-008 }\end{array}$ \\
\hline $\begin{array}{l}\text { RX-RC1-1 } \\
\text { radiation } \\
\text { preamplifier }\end{array}$ & $\begin{array}{c}\text { lst floor of } \\
\text { condenser room, } \\
\text { Sample/monitor } \\
\text { cabinet }\end{array}$ & $N / A$ & $\begin{array}{l}\text { Daily verification: } \\
\text { TF-OR-OFR-001 } \\
\text { 92-day functional } \\
\text { test: } \\
\text { TF-FT-680-018 } \\
\text { 12-mo 100p cal: } \\
\text { TF-CC-690-008 }\end{array}$ \\
\hline $\begin{array}{l}\text { RX-RC1-2 } \\
\text { Radiation } \\
\text { amplifier }\end{array}$ & Control room & $N / A$ & $\begin{array}{l}\text { Daily verification: } \\
\text { TF-OR-0FR-001 } \\
\text { 92-day functional } \\
\text { test: } \\
\text { TF-FT-680-018 } \\
\text { 12-mo 100p cal: } \\
\text { TF-CC-690-008 }\end{array}$ \\
\hline
\end{tabular}


Table 7-4. Monitoring Instrumentation for 242-A Steam Condensate System Waste Stream. (Hanford Site Stream Code ASC) (3 sheets)

\begin{tabular}{|c|c|c|c|}
\hline Instrument type & $\begin{array}{l}\text { Physical } \\
\text { location }\end{array}$ & $\begin{array}{c}\text { Alarming or } \\
\text { diversion set } \\
\text { points }\end{array}$ & $\begin{array}{l}\text { Calibration type, } \\
\text { frequency, and } \\
\text { procedure number }\end{array}$ \\
\hline $\begin{array}{l}\text { RX-RCl-3 } \\
\text { Radiation pulse } \\
\text { height analyzer }\end{array}$ & Control room & $\mathrm{N} / \mathrm{A}$ & $\begin{array}{l}\text { Daily verification: } \\
\text { TF-OR-0FR-001 } \\
\text { 92-day functional } \\
\text { test: } \\
\text { TF-FT-680-018 } \\
\text { 12-mo 100p cal: } \\
\text { TF-CC-690-008 }\end{array}$ \\
\hline $\begin{array}{l}\text { RIAS-RC1-1 } \\
\text { Lin/log ratemeter } \\
\text { alarm switch } \\
\text { Range: } 0-100 \%\end{array}$ & Control room & $\begin{array}{l}\text { High radiation } \\
\text { alarm } \\
\text { at } 80 \mathrm{cps}\end{array}$ & $\begin{array}{l}\text { Daily verification: } \\
\text { TF-OR-0FR-001 } \\
\text { 92-day functional } \\
\text { test: } \\
\text { TF-FT-680-018 } \\
\text { 12-mo 100p cal: } \\
\text { TF-CC-690-008 }\end{array}$ \\
\hline $\begin{array}{l}\mathrm{JC}-\mathrm{RC} 1-1 \\
\mathrm{RC} 1 \text { radiation } \\
\text { monitor power } \\
\text { control }\end{array}$ & Control room & $N / A$ & $\begin{array}{l}\text { Daily verification: } \\
\text { TF-OR-OFR-0O1 }\end{array}$ \\
\hline $\begin{array}{l}\text { RXAS-RCl-1 } \\
\text { Radiation fail } \\
\text { alarm switch }\end{array}$ & Control room & $N / A$ & $\begin{array}{l}\text { Daily verification: } \\
\text { TF-OR-OFR-001 } \\
\text { 92-day functional } \\
\text { test: } \\
\text { TF-TF-680-018 } \\
\text { 12-mo 10op cal: } \\
\text { TF-CC-690-008 }\end{array}$ \\
\hline $\begin{array}{l}\text { RXA-RC1-1 } \\
\text { SC sampler } \\
\text { radiation alarm }\end{array}$ & Control room & $\begin{array}{l}\text { High radiation } \\
\text { alarm at } 80 \mathrm{cps}\end{array}$ & $\begin{array}{l}\text { 92-day functional } \\
\text { test: } \\
\text { TF-FT-680-018 }\end{array}$ \\
\hline $\begin{array}{l}\text { RAH-RCl-1 } \\
\text { Radiation alarm } \\
\text { high }\end{array}$ & CASS & $\begin{array}{l}\text { High radiation } \\
\text { alarm at } 80 \mathrm{cps}\end{array}$ & $\begin{array}{l}\text { 92-day functional } \\
\text { test: } \\
\text { TF-FT-680-018 }\end{array}$ \\
\hline
\end{tabular}


Table 7-4. Monitoring Instrumentation for 242-A Steam Condensate System Waste Stream. (Hanford Site Stream Code ASC) (3 sheets)

\begin{tabular}{|c|c|c|c|}
\hline Instrument type & $\begin{array}{l}\text { Physical } \\
\text { location }\end{array}$ & $\begin{array}{c}\text { Alarming or } \\
\text { diversion set } \\
\text { points }\end{array}$ & $\begin{array}{l}\text { Calibration type, } \\
\text { frequency, and } \\
\text { procedure number }\end{array}$ \\
\hline $\begin{array}{l}\text { RI-RCI-1 } \\
\text { SC sampler } \\
\text { radiation } \\
\text { indicator }\end{array}$ & $\begin{array}{c}\text { Control room } \\
\text { - MCS }\end{array}$ & $\begin{array}{l}\text { High radiation } \\
\text { a)arm at } 80 \mathrm{cps}\end{array}$ & $\begin{array}{l}\text { Daily verification: } \\
\text { TF-OR-OFR-001 } \\
\text { 92-day functional } \\
\text { test: } \\
\text { TF-FT-680-018 }\end{array}$ \\
\hline $\begin{array}{l}\text { LEL-RCl-1 } \\
\text { Weir level low } \\
\text { element }\end{array}$ & Tank C-103 & $\begin{array}{l}\text { Weir level low } \\
\text { alarms at } 17 \text { in. } \\
\text { below top } \\
\text { of tank }\end{array}$ & $\begin{array}{l}\text { Operational check: } \\
\text { (12-mo) } \\
7-G N-42\end{array}$ \\
\hline $\begin{array}{l}\text { LYL-RCI-1 } \\
\text { Weir level Low } \\
\text { alarm switch }\end{array}$ & Tank C-103 & $\begin{array}{l}\text { Weir level 1ow } \\
\text { alarms at } 17 \mathrm{in} . \\
\text { below top } \\
\text { of tank }\end{array}$ & $\begin{array}{l}\text { System test: } \\
(12-\mathrm{mo}) \\
7-\mathrm{GN}-42 \\
\text { PSCP-6-011 }\end{array}$ \\
\hline $\begin{array}{l}\text { LSL-RC1-1 } \\
\text { Weir box level } \\
\text { low alarm }\end{array}$ & $\begin{array}{c}\text { Control room } \\
- \text { MCS }\end{array}$ & $\begin{array}{l}\text { Weir level 1ow } \\
\text { alarms at } 17 \text { in. } \\
\text { below top } \\
\text { of tank }\end{array}$ & $\begin{array}{l}\text { System Test: } \\
(12-\mathrm{mo}) \\
7-\mathrm{GN}-42\end{array}$ \\
\hline $\begin{array}{l}\text { LEL-C103-1 } \\
\text { Weir box overflow } \\
\text { trap level } \\
\text { element }\end{array}$ & $\begin{array}{l}\text { Basement of } \\
\text { condenser room } \\
\text { Tank C-103 } \\
\text { overflow trap }\end{array}$ & N/A & $\begin{array}{l}\text { Precal./cert. } \\
\text { functional test: } \\
(12-\mathrm{mo}) \\
7-\mathrm{GN}-38\end{array}$ \\
\hline $\begin{array}{l}\text { LYL-C103-1 } \\
\text { Weir box overflow } \\
\text { trap level relay }\end{array}$ & Control room & $N / A$ & $\begin{array}{l}\text { Precal./cert. } \\
\text { functional test: } \\
(12-\mathrm{mo}) \\
7-G N-38\end{array}$ \\
\hline $\begin{array}{l}\text { FQI-RC1-D } \\
\text { Diverted SC } \\
\text { totalizer } \\
0-99999 \mathrm{gal} / \mathrm{min}\end{array}$ & MCS & $N / A$ & $N / A$ \\
\hline $\begin{array}{l}\text { FQI-RCINM } \\
\text { Weir box flow } \\
\text { totaiizer } \\
0-99999 \mathrm{gal} / \mathrm{min}\end{array}$ & MCS & $N / A$ & $N / A$ \\
\hline $\begin{array}{l}\text { FQIC-RCl } \\
\text { RCl sampler } \\
\text { controller } \\
0-100 \mathrm{gal} / \mathrm{min}\end{array}$ & MCS & $N / A$ & $N / A$ \\
\hline
\end{tabular}


Table 7-4. Monitoring Instrumentation for 242-A Steam Condensate System Waste Stream. (Hanford Site Stream Code ASC) (3 sheets)

\begin{tabular}{|l|c|c|c|}
\hline \multicolumn{1}{|c|}{ Instrument type } & $\begin{array}{c}\text { Physical } \\
\text { location }\end{array}$ & $\begin{array}{c}\text { Alarming or } \\
\text { diversion set } \\
\text { points }\end{array}$ & $\begin{array}{l}\text { Calibration type, } \\
\text { frequency, and } \\
\text { procedure number }\end{array}$ \\
\hline $\begin{array}{l}\text { FAL-RC1-1 } \\
\text { Steam condensate: } \\
\text { flow-rate alarm: } \\
\text { high and low }\end{array}$ & CASS & N/A & N/A \\
\hline $\begin{array}{l}\text { FI-RC1-1 } \\
\text { SC flow to } \\
\text { SC basin } \\
\text { 0 to 104 gal/min }\end{array}$ & MCS & $\begin{array}{l}\text { Indicates SC flow } \\
\text { to retention } \\
\text { basins }\end{array}$ & $\begin{array}{l}\text { Overall } \\
\text { calibration: } \\
12 \text {-mo }\end{array}$ \\
\hline $\begin{array}{l}\text { FT-RCl-1 } \\
\text { SC elec. flow } \\
\text { transmitter }\end{array}$ & $\begin{array}{l}\text { 1st floor of } \\
\text { condenser room }\end{array}$ & N/A & $\begin{array}{l}\text { Overall } \\
\text { calibration: } \\
\text { (12-mo) } \\
\text { PSCP-6-188 }\end{array}$ \\
\hline
\end{tabular}

NOTE: CASS = computer automated surveillance system.

$\mathrm{cpm}=$ counts per minute.

$\mathrm{cps}=$ counts per second.

MCS = monitor control system

$S C=$ steam condensate. 
WHC-EP-0466-1

This page intentionally left blank. 


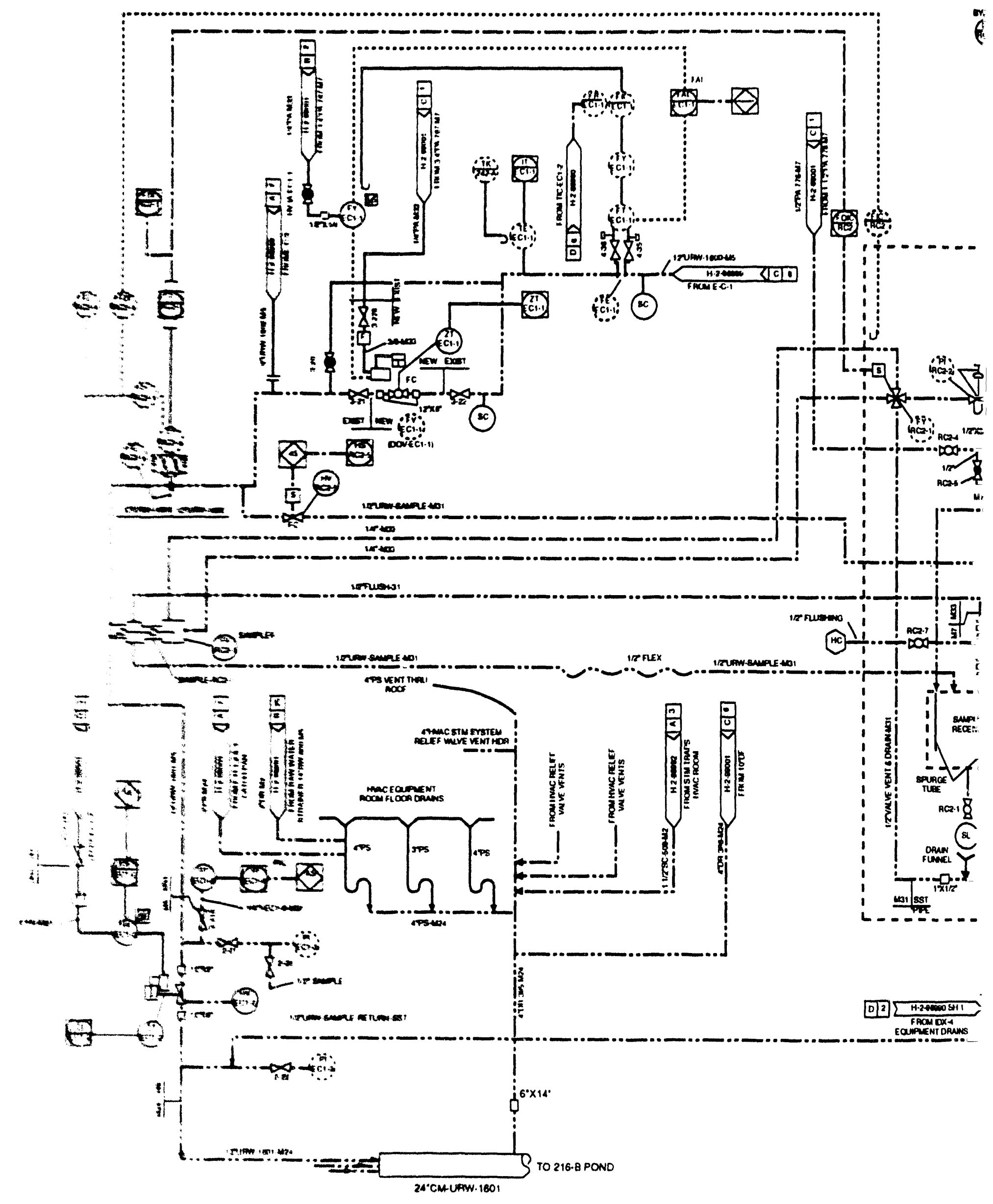


WHC-EP-0466-1

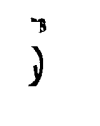
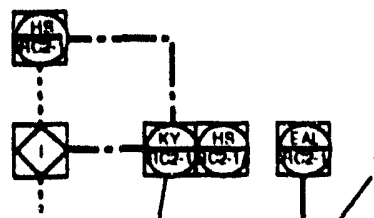

i

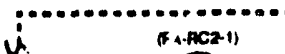

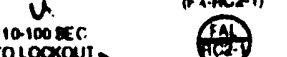

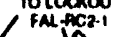

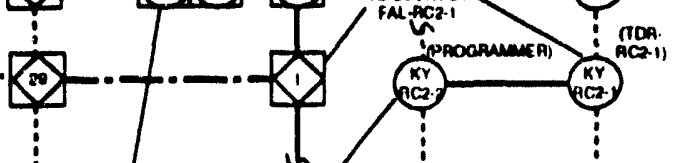

10)

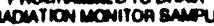
CEL ROA S MEATHETAOA

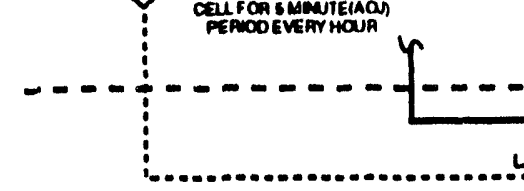

(FHC2-2) (fHCall

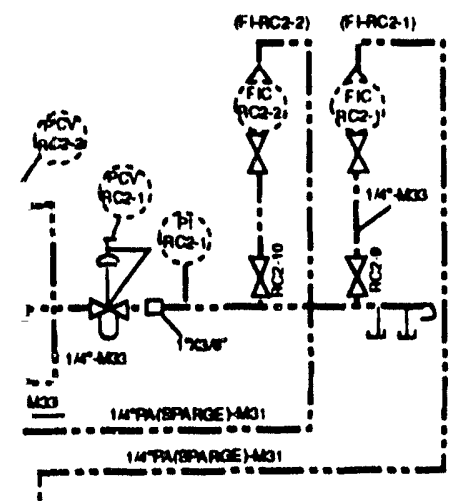

r

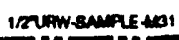

(Evacin)

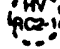

OMERT "E

ircumsampre

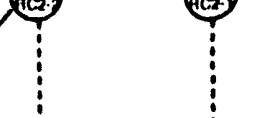

Figure 7-2. P\&ID Used Raw Water System.

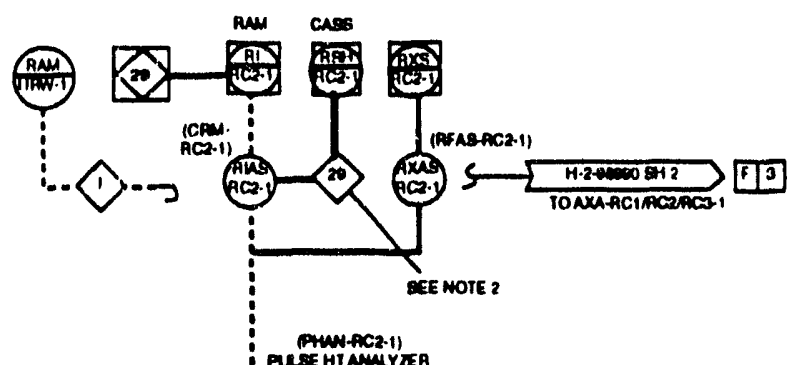

Axia.

(a)

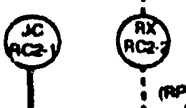

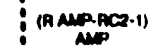

inpamanace.1

ax
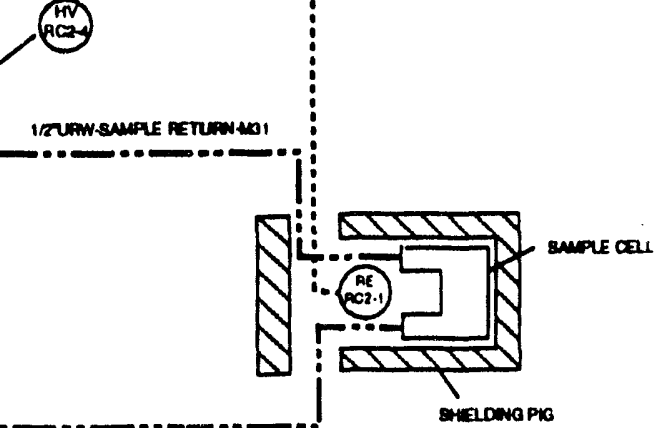

PATUTLON MOENITOH 
7.1.2.5 Steam Condensate Instrumentation. Radiation information is monitored on the MCS by radiation indicator RI-RCI-1. A count-rate meter is selfcontained with a range of 10 to $1.0 \times 10^{+6} \mathrm{cpm}( \pm 2.0 \%)$ on an adjustable logarithmic scale. Radiation alarms are activated at $80 \mathrm{cps}$ on increasing radiation. Table 7-4 displays the instrumentation related to the sampling/monitoring systems for the steam condensate stream. Instrument locations, calibration frequencies, and alarming or diversion set points are included in this matrix. Drawing No. H-2-98993 (Figure 7-3) is an instrument flow diagram for the steam condensate system. 
WHC-EP-0466-1

This page intentionally left blank. 


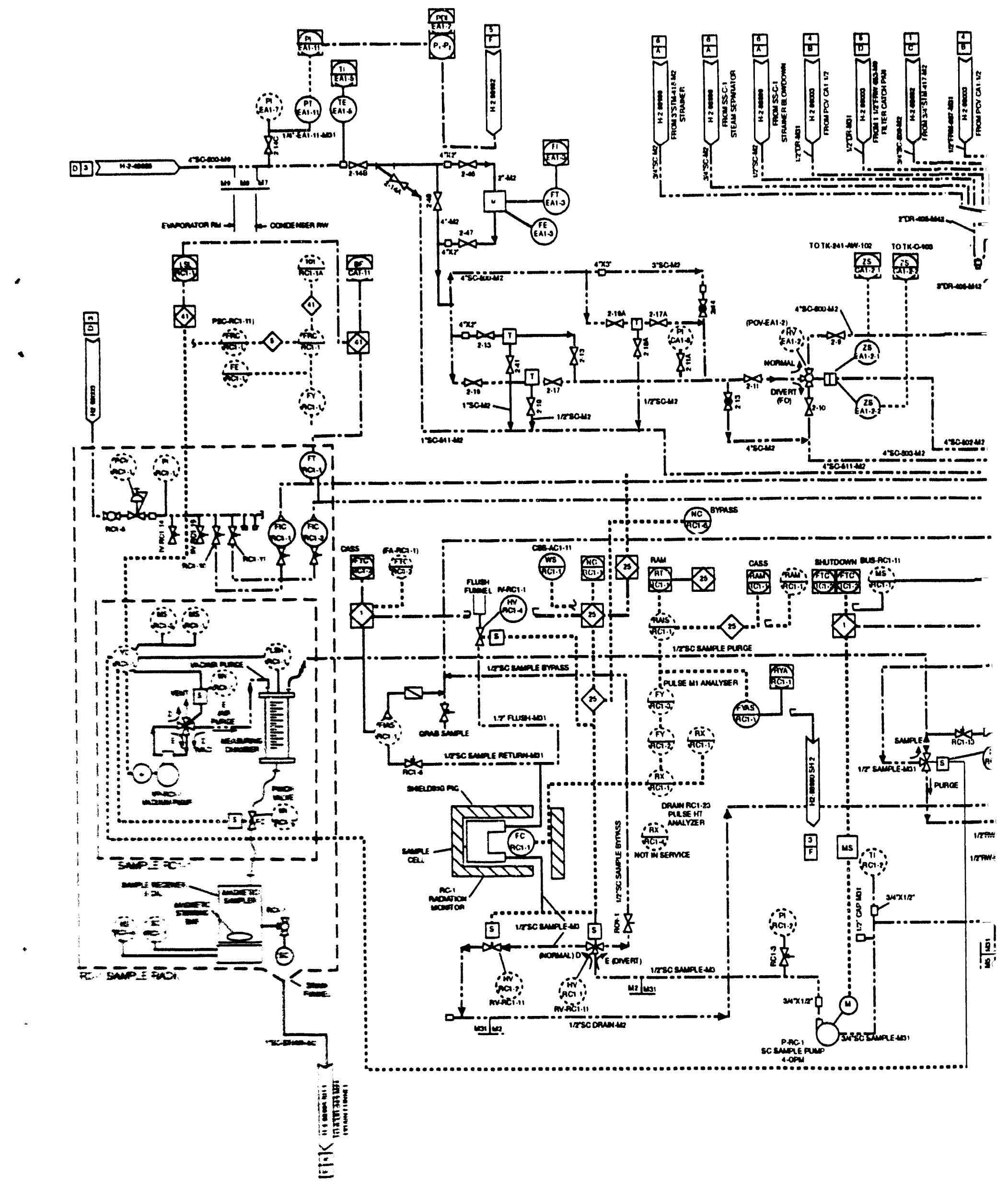




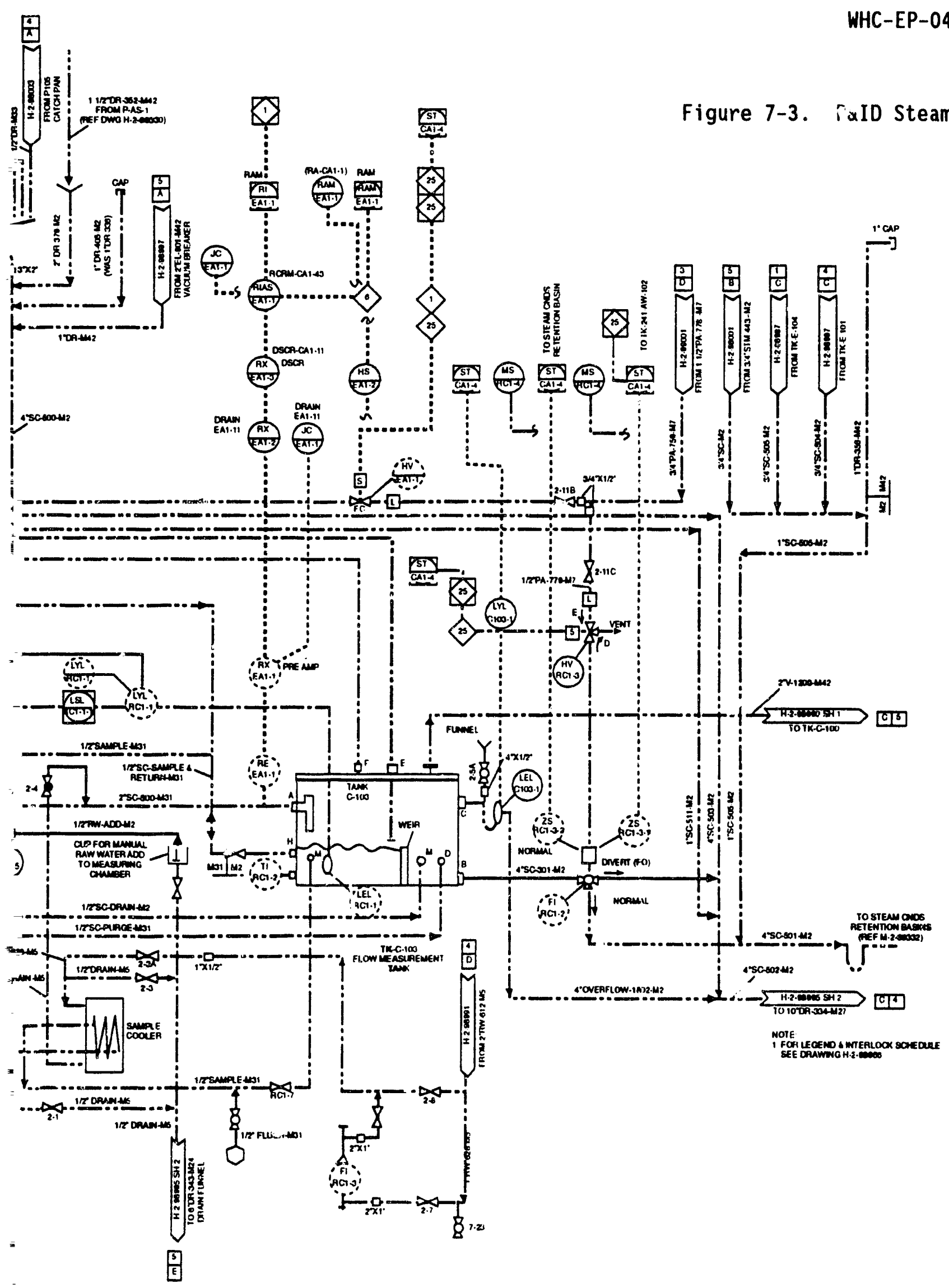

23301012.1 
WHC-EP-0466-1

\subsection{HISTORICAL MONITORING/SAMPLING DATA FOR EFFLUENT STREAMS}

\subsection{NORMAL CONDITIONS}

This section provides a brief summary of pertinent historical data accumulated under normal operating conditions. These data are used to verify that the projected effluent characteristics are defensible.

\subsubsection{Vessel Vent}

Radionuclide effluent emission data for the vessel vent stack are presented in Table 8-1. The data contained within this table were obtained from the following sources.

- 1984, 1985, and 1986 Average Release Concentration: reference-WHC-SD-WM-SAR-023, 242-A Evaporator Safety Analysis Report (WHC 1988a)

- 1987 Average Release Concentration: reference--WHC-EP-0141, Westinghouse Hanford Company Effluent Discharges and Solid Waste Management Report for 1987: 200/600/1100 Areas (WHC 1988d)

- 1988 Average Release Concentration: reference--WHC-EP-0141-1, Westinghouse Hanford Company Effluent Discharges and Solid Waste Management Report for 1988: 200/600 Areas (WHC 1988e)

- 1989 Stack Release Concentration/Quantity: reference-WHC-EP-0141-2, Westinghouse Hanford Company Effluent Discharges and Solid Waste Management Report for 1989: 200/600 Areas (WHC 1990a).

No data exists on airborne releases for CYs 1991 - 1992 because the facility did not operate. However, liquid effluent data are available for CYs 1991 - 1992.

\subsubsection{Building Ventilation}

Table 8-2 contains radionuclide effluent emission data for the building ventilation stack. These data were obtained from the following sources.

- 1984, 1985, and 1986 Average Release Concentration: reference-WHC-SD-WM-SAR-023, 242-A Evaporator Safety Analysis Report

- 1987 Average Release Concentration: reference--WHC-EP-0141, Westinghouse Hanford Company Effluent Discharges and Solid Waste Management Report for 1987: 200/600/1100 Areas

- 1988 Average Release Concentration: reference--WHC-EP-0141-1, Westinghouse Hanford Company Effluent Discharges and Solid Waste Management Report for 1988: 200/600 Areas. 
Table 8-1. Stack 296-A-22 Gaseous Radioactive Effluent Emissions Data.

\begin{tabular}{|c|c|c|c|c|c|c|}
\hline Emission & 1984 & 1985 & 1986 & 1987 & 1988 & 1989 \\
\hline \multirow{3}{*}{$\begin{array}{c}\text { Total } \\
\text { volume } \\
\text { (L) }\end{array}$} & $7.7 E+09$ & $9.7 E+09$ & $9.4 E+09$ & $1.02 E+10$ & $1.03 E+10$ & $4.81 E+09$ \\
\hline & $(\mu \mathrm{Ci} / \mathrm{mL})$ & $(\mu \mathrm{C} \mathrm{i} / \mathrm{mL})$ & $(\mu \mathrm{Ci} / \mathrm{mL})$ & $(\mu \mathrm{Ci} / \mathrm{mL})$ & $(\mu \mathrm{Ci} / \mathrm{mL})$ & $(\mu \mathrm{Ci} / \mathrm{mL})$ \\
\hline & (Ci) & (Ci) & (Ci) & (Ci) & (Ci) & (Ci) \\
\hline \multirow[t]{2}{*}{ Alpha } & $1.9 E-14$ & $3.5 \mathrm{E}-15$ & $4.6 E-15$ & $3.5 E-15$ & $4.0 E-15$ & $3.5 E-15$ \\
\hline & $1.4 E-7$ & $3.4 E-8$ & $4.32 \mathrm{E}-8$ & $3.57 \mathrm{E}-8$ & $4.13 E-08$ & $1.68 \mathrm{E}-08$ \\
\hline \multirow[t]{2}{*}{ Beta } & $4.0 E-12$ & $9.3 E-13$ & $2.1 E-12$ & $2.8 E-14$ & $6.49 \mathrm{E}-13$ & $2.04 E-12$ \\
\hline & $3.1 E-5$ & $9.0 E-6$ & $1.97 \mathrm{E}-5$ & $2.82 \mathrm{E}-7$ & $6.69 E-06$ & $9.81 E-06$ \\
\hline${ }^{241} \mathrm{Am}$ & & & & & c & c \\
\hline \multirow[t]{2}{*}{${ }^{137} \mathrm{Cs}$} & & $8 E-15^{*}$ & $1 E-14 *$ & $8 E-15$ & $6 E-15$ & $9.32 E-15$ \\
\hline & & & & 9.81 E-06 & $6.18 \quad E-08$ & $4.5 E-08$ \\
\hline \multirow[t]{2}{*}{${ }^{129} I$} & \multirow[t]{2}{*}{ ND } & \multirow[t]{2}{*}{ ND } & \multirow[t]{2}{*}{ ND } & $5.5 E-12$ & $2 E-11$ & $1.57 E-11$ \\
\hline & & & & & $2.1 E-04$ & $7.6 \mathrm{E}-05$ \\
\hline${ }^{131} I$ & ND & ND & $\overline{N D}$ & & & \\
\hline${ }^{239,240} \mathrm{Pu}$ & & & & & c & C \\
\hline \multirow[t]{2}{*}{${ }^{106} \mathrm{Ru}$} & \multirow[t]{2}{*}{$\overline{N D}$} & \multirow[t]{2}{*}{ ND } & \multirow[t]{2}{*}{$\overline{N D}$} & $3.5 \mathrm{E}-13$ & $2 E-10$ & $1.21 E-10$ \\
\hline & & & & & $2.1 E-3$ & $5.8 \quad E-04$ \\
\hline${ }^{103} \mathrm{Ru}$ & ND & $\overline{N D}$ & ND & $4 E-14$ & & \\
\hline \multirow[t]{2}{*}{${ }^{113} \mathrm{Sn}$} & \multirow[t]{2}{*}{ ND } & \multirow[t]{2}{*}{ ND } & \multirow[t]{2}{*}{ ND } & $8.5 E-14$ & $4 E-13$ & $3.61 \mathrm{E}-13$ \\
\hline & & & & & $4.12 E-06$ & $1.7 E-06$ \\
\hline \multirow[t]{2}{*}{${ }^{89,90} \mathrm{Sr}$} & & $4 E-14 *$ & $2 E-15 *$ & $3.75 \mathrm{E}-15$ & $3 E-15$ & $3.56 E-15$ \\
\hline & & & & & $3.1 \quad E-08$ & $1.7 E-08$ \\
\hline \multirow[t]{2}{*}{${ }^{125} \mathrm{Sb}$} & \multirow[t]{2}{*}{ ND } & \multirow[t]{2}{*}{ ND } & $1.0 E-11 *$ & $3 E-13$ & 2. $E-12$ & $1.63 \mathrm{E}-12$ \\
\hline & & & $9.4 E-5$ & & $2.1 E-5$ & $7.9 E-06$ \\
\hline
\end{tabular}

NOTE: 1. Stack was not operational in 1990 or 1991.

2. $N D=$ not detected.

3. $\quad c=$ analysis is not necessary (as determined from inventory, effluent history, and/or gross alpha/beta analyses).

4. *Values were obtained from documents numbered RHO-HS-SR-85-13P (RHO 1986), RHO-HS-SR-86-13 (RHO 1987b), and RHO-HS-SR-86-2 4QGAS P (RHO 1987a) 
Table 8-2. Stack 296-A-21 Gaseous Radioactive Effluent Emissions Data.

\begin{tabular}{|c|c|c|c|c|c|c|c|c|}
\hline Emission & 1984 & 1985 & 1986 & 1987 & 1988 & 1989 & 1990 & 1991 \\
\hline \multirow{3}{*}{$\begin{array}{l}\text { Total } \\
\text { volume } \\
(L)\end{array}$} & $2.4 E+11$ & $2.8 E+11$ & $2.8 E+11$ & $2.8 E+11$ & $2.59 E+11$ & $2.90 E+11$ & $2.90 E+11$ & $3.0 E+11$ \\
\hline & \multirow{2}{*}{$(\mu \mathrm{Ci} / \mathrm{mL})$} & \multirow{2}{*}{$(\mu \mathrm{Ci} / \mathrm{mL})$} & \multirow{2}{*}{$(\mu \mathrm{Ci} / \mathrm{mL})$} & $(\mu \mathrm{Ci} / \mathrm{mL})$ & $(\mu \mathrm{Ci} / \mathrm{mL})$ & $(\mu \mathrm{Ci} / \mathrm{mL})$ & $(\mu \mathrm{Ci} / \mathrm{mL})$ & $(\mu \mathrm{Ci} / \mathrm{mL})$ \\
\hline & & & & (ci) & (ci) & (Ci) & (ci) & (ci) \\
\hline \multirow[t]{2}{*}{ Alpha } & \multirow[t]{2}{*}{$3.9 E-15$} & \multirow[t]{2}{*}{$3.5 E-15$} & \multirow[t]{2}{*}{$3.5 E-15$} & $3.5 E-15$ & $3.5 E-15$ & $3.5 E-15$ & $8.3 E-16$ & $1.6 E-12$ \\
\hline & & & & $18-6$ & $9.08 \mathrm{E}-7$ & $1.02-06$ & ND & $4.9 \mathrm{E}-04$ \\
\hline \multirow[t]{2}{*}{ Beta } & \multirow[t]{2}{*}{$5.1 E-14$} & \multirow[t]{2}{*}{2.7 E-13 } & \multirow[t]{2}{*}{1.7 E-14 } & 1.2 E-14 & 1.2 E- 14 & $1.20 \mathrm{E}-14$ & $3.2 \mathrm{E}-14$ & $3.8 E-13$ \\
\hline & & & & $3.4 \mathrm{E} 6$ & $3.11 \mathrm{E}-6$ & $3.49 \mathrm{E}-06$ & $9.5 \mathrm{E}-06$ & $1.1 \mathrm{E}-04$ \\
\hline \multirow{2}{*}{$241_{\mathrm{Am}}$} & \multirow{2}{*}{ a } & \multirow{2}{*}{$\mathbf{a}$} & \multirow{2}{*}{ a } & 2.2 E-14 & a & $2.06 E-15$ & $<2.1 E-15$ & $<2.3 E-15$ \\
\hline & & & & $\theta$ & 8 & 5.94807 & No & ND \\
\hline \multirow{2}{*}{$239,240 \mathrm{Pu}$} & \multirow{2}{*}{$\mathbf{a}$} & \multirow{2}{*}{$\mathbf{a}$} & \multirow{2}{*}{ a } & 1.5 E-15 & a & $1.03 E-15$ & $<1.1 E-15$ & $<3.5$ E-15 \\
\hline & & & & $a$ & $a$ & 2.97 E-07 & ND & ND \\
\hline
\end{tabular}

NOTE: $a=$ no analysis done.

ND = none detected.

- 1989 Stack Release Concentration/Quantity: reference--

WHC-EP-0141-2, Westinghouse Hanford Company Effluent Discharges and Solid Waste Management Report for 1989: 200/600 Areas.

- 1990 Stack Release and Average Concentration: reference-WHC-EP-0527, Environmental Releases for Calender Year 1990 (WHC 1991j).

- 1991 Stack Release and Average Concentration: reference-- WHC-EP0527-1, Environmental Releases for Calendar Year 1991 (WHC 1992k).

\subsubsection{Steam Condensate}

Radionuclide effluent release data for the 242-A Evaporator steam condensate stream are compiled in Table 8-3. These data were taken from the following referenced documents.

- For 1987/1988/1989 values: reference--WHC-EP-0141/-1/-2, Westinghouse Hanford Company Effluent Discharges and Solid Waste Management Report for 1987/1988/1989: 200/600 Areas

- For 1984/1985/1986 values: reference--WHC-SD-WM-SAR-023, 242-A Evaporator Safety Analysis Report.

- For 1990 values: reference--WHC-EP-0527, Environmental Releases for Calendar Year 1990 (WHC 1991j).

- For 1991 values: reference--WHC-EP-0527-1, Environmental Releases for Calendar Year 1991 (WHC 1992k) 
Table 8-3. Steam Condensate Radionuclide Effluent Release Data.

\begin{tabular}{|c|c|c|c|c|c|c|c|c|}
\hline Effluent & 1984 & 1985 & 1986 & 1987 & 1988 & 1989 & 1990 & 1991 \\
\hline \multirow{3}{*}{$\begin{array}{l}\text { Total } \\
\text { volume } \\
(L)\end{array}$} & $6.6 E+07$ & $8.5 E+07$ & $6.8 E+07$ & $4.9 \varepsilon+07$ & $6.55 E+07$ & $1.70 \mathrm{E}+07$ & $4.1 E+06$ & $3.5 E+05$ \\
\hline & \multirow{2}{*}{$(\mu \mathrm{Ci} / \mathrm{mL})$} & \multirow{2}{*}{$(\mu \mathrm{Ci} / \mathrm{mL})$} & \multirow{2}{*}{$(\mu \mathrm{Ci} / \mathrm{mL})$} & $(\mu \mathrm{Ci} / \mathrm{mL})$ & $(\mu C i / m L)$ & $\left(\mu C i / m_{L}\right)$ & $\mu \mathrm{Ci} / \mathrm{mL}$ & $\mu \mathrm{Ci} / \mathrm{mL}$ \\
\hline & & & & (Ci) & (Ci) & (ci) & (Ci) & (Ci) \\
\hline \multirow[t]{2}{*}{ Alpha } & \multirow[t]{2}{*}{5.3 E-09 } & \multirow[t]{2}{*}{9.1 E-09 } & \multirow[t]{2}{*}{4.7 E-09 } & \multirow[t]{2}{*}{3 E-09 } & 3 E-09 & 2.1 E-09 & 2.0 E-08 & $1.4 \varepsilon=09$ \\
\hline & & & & & $2 E-04$ & $3,6 \mathrm{E}-05$ & $8.5 \mathrm{E}-05$ & $4.8 \mathrm{E}-07$ \\
\hline \multirow[t]{2}{*}{ Beta } & \multirow[t]{2}{*}{2.6 E-08 } & \multirow[t]{2}{*}{$4.8 E-08$} & \multirow[t]{2}{*}{$8.5 E-08$} & \multirow[t]{2}{*}{$1 E-08$} & $6 \mathrm{E}-08$ & 3.7 E-08 & 1.5 E-07 & 1.3 E-08 \\
\hline & & & & & $4 E-03$ & $6.4 E-04$ & $6.4 E_{0} 04$ & $4.7 \mathrm{E}-06$ \\
\hline \multirow[t]{2}{*}{$\overline{3_{H}}$} & \multirow[t]{2}{*}{$8.3 E-06$} & \multirow[t]{2}{*}{$1.2 E-04$} & \multirow[t]{2}{*}{$2.7 E-05$} & \multirow[t]{2}{*}{2 E-06 } & $4 E-05$ & 7.4 E-07 & 9.1 E-07 & $2.2 E-06$ \\
\hline & & & & & $3 E+00$ & $1.3 E-02$ & $3.8 \mathrm{E}-03$ & $7.5 \mathrm{E}-04$ \\
\hline \multirow[t]{2}{*}{$241_{A m}$} & & & & & c & 2.5 E-08 & 2.7 E-08 & $<2.2$ E-08 \\
\hline & & & & & c & $4.2 \mathrm{E}-04$ & $1,1 \mathrm{E}-04$ & ND \\
\hline${ }^{137} \mathrm{cs}$ & \multirow[t]{2}{*}{ ND } & \multirow[t]{2}{*}{ ND } & \multirow[t]{2}{*}{ ND } & \multirow[t]{2}{*}{6 E-08 } & 7 E-08 & 5.2 E-08 & $7.6 E-08$ & $<5.8 E-08$ \\
\hline & & & & & 5 E-03 & $8.8 \mathrm{E}-04$ & $3,1 \mathrm{E}-04$ & No \\
\hline $147 \mathrm{Pm}$ & HD & ND & ND & & & & $c$ & c \\
\hline $129_{1}$ & & & ND & & c & c & c & c \\
\hline \multirow[t]{2}{*}{ Uranium } & \multirow[t]{2}{*}{ ND } & \multirow[t]{2}{*}{ ND } & \multirow[t]{2}{*}{ ND } & & c & 2.9 E-09 & 1.4 E-09 & 8.0 E-10 \\
\hline & & & & & c & $4.9 \mathrm{E}-05$ & $5.6 \mathrm{E}-06$ & $2.8 E-07$ \\
\hline \multirow[t]{2}{*}{$239,240 \mathrm{Pu}$} & & & & & c & $1.3 E-08$ & $1.1 E-08$ & $<1.1 E-08$ \\
\hline & & & & & $c$ & $2.2 E-04$ & $4.7 \mathrm{FO} 0 \mathrm{~S}$ & ND \\
\hline \multirow[t]{2}{*}{$89,90 \mathrm{Sr}$} & \multirow[t]{2}{*}{ ND } & \multirow[t]{2}{*}{ ND } & \multirow[t]{2}{*}{ ND } & \multirow[t]{2}{*}{$2 E-08$} & $2 E-08$ & 1.5 E-08 & $2.9 E-08$ & $1.9 E-08$ \\
\hline & & & & & 1 E-03 & $2.6 \mathrm{E}-04$ & 1.2 E-04 & 6.7 E-06 \\
\hline
\end{tabular}

NOTE: $N D=$ not detected.

$c=$ analysis is not necessary (as determined from inventory, effluent history, and/or gross alpha/beta analyses). 


\subsubsection{Cooling Water}

Table 8-4 contains the radioactive effluent release data used to calculate the radionuclide source terms for the used cooling water waste stream. These data were obtained from the following sources.

- For 1987/1988/1989 values: reference--WHC-EP-0141/-1/-2, West inghouse Hanford Company Effluent Discharges and Solid Waste Management Report for 1987/1988/1989: 200/600 Areas

- For 1984/1986/1986 values: reference--WHC-SD-WM-SAR-023, 242-A Evaporator Safety Analysis Report.

Because the 242-A Evaporator was not operating from 1989 to the present, there was no cooling water discharge from the facility to report for 1990 or 1991 .

Additional data for the alpha and beta concentrations potentially contained within the cooling water are provided by WHC-EP-0342, Addendum 21, 242-A Evaporator Cooling Water Stream-Specific Report (WHC 1990b). These values are $1.59 \times 10^{-09} \mu \mathrm{Ci} / \mathrm{mL}$ for alpha and $3.19 \times 10^{-08} \mu \mathrm{Ci} / \mathrm{mL}$ for beta.

\subsection{UPSET CONDITIONS}

Upset conditions that occurred in the past and are relevant to future operations at the facility are presented in the following paragraphs. Each applicable event is discussed briefly. The discussion provides a description of each event and lists the type and amount of material involved. The pathway of any release and the resulting monitoring/sampling data obtained during the event are also provided.

A thorough examination of any documented unusual events was conducted. The following are the events that are relevant to this FEMP.

1. On December 9, 1989, approximately 16 oz of nitric acid leaked in the AMU room from the decontamination tank (E-104). The CERCLA RQ is $4.54 \mathrm{~kg}(10 \mathrm{lb})$. The leakage was from a valve on the tank. The leakage drained down the drain in the AMU room and ultimately to the evaporator feed tank (TK-102-AW). It was neutralized and cleaned up within $15 \mathrm{~min}$.

2. On December 7, $1989,0.53$ lb of nitric acid or NOX was discharged to the environment via heating of the decontamination tank (E-104). The fumes were discharged out of the tank vent header, which exits outside, north of the building. Drager tube samples were taken to determine the leak concentration. The amount that leaked was calculated in Internal Memo 13331-89-482 from Waste Concentration Process Engineering Unit, dated December 13, 1989, subject: Nitric "Acid Released During 242-A Evaporator Flush" (WHC 1989c). This memo also calculated the equivalent release that would have occurred at room temperature. This release, over a $24-h$ period, equates to $9.5 \times 10^{-03} \mathrm{lb} / \mathrm{d}$. The CERCLA RQ is $10 \mathrm{lb} / \mathrm{d}$. 
Table 8-4. Cooling Water Radioactive Effluent Release Data.

\begin{tabular}{|c|c|c|c|c|c|c|}
\hline Effluent & 1984 & 1985 & 1986 & 1987 & 1988 & 1989 \\
\hline \multirow{3}{*}{$\begin{array}{l}\text { Total } \\
\text { volume } \\
\text { (L) }\end{array}$} & $2.9 E+09$ & $3.5 E+09$ & $3.7 E+09$ & $5.35 E+09$ & $6.34 E+09$ & $1.89 E+09$ \\
\hline & \multirow{2}{*}{$(\mu \mathrm{Ci} / \mathrm{mL})$} & \multirow{2}{*}{$(\mu \mathrm{Ci} / \mathrm{mL})$} & \multirow{2}{*}{$(\mu \mathrm{Ci} / \mathrm{mL})$} & \multirow{2}{*}{$(\mu \mathrm{Ci} / \mathrm{mL})$} & $(\mu \mathrm{Ci} / \mathrm{mL})$ & $(\mu \mathrm{Ci} / \mathrm{mL})$ \\
\hline & & & & & (Ci) & (Ci) \\
\hline \multirow[t]{2}{*}{ Alpha } & \multirow[t]{2}{*}{$4.4 E-09$} & \multirow[t]{2}{*}{$6.9 E-09$} & \multirow[t]{2}{*}{$5.8 E-09$} & \multirow[t]{2}{*}{$3 E-09$} & $2 E-09$ & 2.0 E-09 \\
\hline & & & & & $2 E-02$ & $3.8 \mathrm{E}-03$ \\
\hline \multirow[t]{2}{*}{ Beta } & \multirow[t]{2}{*}{$2.5 E-08$} & \multirow[t]{2}{*}{$2.5 E-08$} & \multirow[t]{2}{*}{$9.4 E-08$} & \multirow[t]{2}{*}{$3 E-08$} & $4 E-08$ & 1.1 E-08 \\
\hline & & & & & $3 E-01$ & $2.0 \mathrm{E}-02$ \\
\hline \multirow[t]{2}{*}{${ }^{3} \mathrm{H}$} & \multirow[t]{2}{*}{ ND } & \multirow[t]{2}{*}{$3.1 E-06$} & \multirow[t]{2}{*}{$1.1 E-05$} & \multirow[t]{2}{*}{$5 E-05$} & $2 E-05$ & $5.2 E-07$ \\
\hline & & & & & $1 \mathrm{E}+02$ & 9.8 E-01 \\
\hline \multirow[t]{2}{*}{${ }^{241} \mathrm{Am}$} & & & & & \multirow[t]{2}{*}{ c } & $3.3 \mathrm{E}-08$ \\
\hline & & & & & & $6.3 \mathrm{E}-02$ \\
\hline \multirow[t]{2}{*}{${ }^{137} \mathrm{Cs}$} & \multirow[t]{2}{*}{ ND } & \multirow[t]{2}{*}{ ND } & \multirow[t]{2}{*}{ ND } & \multirow[t]{2}{*}{$5 E-08$} & $6 E-08$ & 5.1 E-08 \\
\hline & & & & & $4 E-01$ & $9.6 \mathrm{E}-02$ \\
\hline \multirow[t]{2}{*}{$239,240 \mathrm{Pu}$} & & & & & \multirow[t]{2}{*}{ c } & $1.7 \mathrm{E}-08$ \\
\hline & & & & & & $3.3 \quad E-02$ \\
\hline \multirow[t]{2}{*}{${ }^{89,90} \mathrm{Sr}$} & \multirow[t]{2}{*}{ ND } & \multirow[t]{2}{*}{ ND } & \multirow[t]{2}{*}{ ND } & \multirow[t]{2}{*}{$2 E-08$} & $2 E-08$ & $1.6 \mathrm{E}-08$ \\
\hline & & & & & $1 E-01$ & $3.1 \quad E-02$ \\
\hline
\end{tabular}

NOTE: ND = not detected.

$c=$ aralysis is not necessary (as determined from inventory, effluent history, and/or gross alpha/beta analyses). 
3. On August 31,1987 , process condensate that was high (greater than CERCLA RQ 1 imits) in $\mathrm{NH}_{4} \mathrm{OH}$ was released to the $216-\mathrm{A}-37-1 \mathrm{crib}$. The release was caused by processing CRW waste high in $\mathrm{NH}_{3}$. The evaporator was shut down as a result. Levels varied from $0.07 \mathrm{~mol} / \mathrm{L}$ to $0.3 \mathrm{~mol} / \mathrm{L}$. In addition, the stack exceeded the $\mathrm{NH}_{3}$ CERCLA limits. Release amounts were calculated at 135 ib out the stack and 1,580 ib to the crib.

4. On September 25,1989 , a 5 to $50 \%$ separable organics layer was discovered in Tank $\mathrm{C}-100$. The tank was flushed (back to the tank farms) to remove the organics.

5. On July 31, 1984, process condensate that was over administrative limits in total beta and ${ }^{90} \mathrm{Sr}$ was discharged to the $216-\mathrm{A}-37-1 \mathrm{crib}$.

6. On July 25, 1980, high radiation readings in the vessel vent initiated alarms and interlocks, which resulted in a shutdown of the evaporator process. It is believed that contaminated steam vented through a dry seal loop on the steam condensate weir overflow and entered the vessel vent stack past the HEPA filters. The contaminated steam was generated by the pump room sump jetting operation. The seal loop is now filled weekly via the maintenance tickler system. 
WHC-EP-0466-1

This page intentionally left blank. 
WHC-EP-0466-1

\subsection{SAMPLING ANALYSIS}

This chapter provides information on the sample exchange processes, chain of custody procedures, and laboratory analytical procedures for the 242-A Evaporator facility effluent streams.

\subsection{EFFLUENT SAMPLE EXCHANGE AND ANALYTICAL LABORATORY PROCEDURES}

This section explains the sample exchange process for the effluent streams at the 242-A Evaporator facility, the analyses instructions given to the laboratory, what happens to the analyses results, and, in general, what happens to the samples at the laboratories.

\subsubsection{Vessel Vent and Building Ventilation Sample Exchange Process}

The sample exchange for the vessel vent and building ventilation systems is accomplished by the facility HP group. The samples are placed in colored envelopes. The color chosen depends on the sample type and purpose. The HP procedure that describes these envelopes is Operational Health Physics Procedure No. 2.1.6, Rev 0, "Air Sample Envelopes," and is contained in WHC-IP-0692, Health Physics Procedures Manual (WHC 1992g).

9.1.1.1 Exchanging Silver Zeolite Cartridges. Silver zeolite cartridges are exchanged in accordance with the 200 Area Health Physics Procedure No. 5.2.2.5, Rev 1, "Silver Zeolite Monitor/Change-Out Program At 241-AW Tank Farm And The 242-A Evaporator." This procedure is contained in WHC-IP-0692. The following discusses the silver zeolite cartridge exchange process.

The silver zeolite cartridges are monitored as follows:

- Before an ASF transfer

- Every $8 \mathrm{~h}$ during an ASF transfer

- At the end of an ASF transfer

- Every $24 \mathrm{~h}$ during nontransfer conditions

- Every $2 \mathrm{~h}$ if abnormal radiation levels are detected or if radiation readings increase more than $16 \mathrm{mR} / \mathrm{h}$ in $8 \mathrm{~h}$. In this case the cartridges are changed out. Two-hour monitoring continues until the radiation buildup decreases to less than $3 \mathrm{mR} / \mathrm{h}$ in each $2-\mathrm{h}$ check. At this point the $8-\mathrm{h}$ monitoring schedule is resumed.

The silver zeolite cartridges are exchanged as follows.

- When the cartridges have been in the sample for one week. For weekly routine sample exchange, a standard sample envelope is used. The envelope is delivered to the 222-S Laboratory within $8 \mathrm{~h}$. 
- When radiation readings indicate a buildup of more than $15 \mathrm{mR} / \mathrm{h}$ within the last $8 \mathrm{~h}$. For samples that have been changed because of high radiation readings, the sample is placed in a red-bordered envelope and delivered immediately to the 222-S Laboratory.

- When requested by operations management.

When silver zeolite sample cartridges (used for exhaust stack effluent sampling) are exchanged, they are placed in white sample envelopes and delivered to the 222-5 Laboratory for analyses. The sample cartridge exchange sequence of events is as follows.

1. A fresh white sample envelope is prepared furnishing the following information:

- Sample cartridge EDP code

- Sample location

- HPT's name and payroll number

- Date and time that the new cartridge will be installed.

2. The fresh sample cartridge is labeled with the applicable EDP code.

3. At this point, the following information is completed on the sample envelope that was left when the previous cartridge was installed:

- The date and time that the cartridge is removed

- The gas flow totalizer (the sample flow totalizer) reading

- The rotameter (the sample flow-rate indicator) reading

- The vacuum (sample obstruction indicator) reading

- The removing HPT's name and payroll number.

4. The cartridge holder is opened and the filter cartridge is carefully removed.

5. The used sample cartridge is placed in a small sample bag and the bag is sealed with a fold of tape.

6. The bagged, used sample cartridge is placed in the sample envelope.

7. The envelope is secured with a pair of rubber bands.

8. The secured envelope is placed in a second sample bag, which is then fastened with a strip of tape.

9. The fresh sample cartridge is installed in the cartridge holder, which is then closed.

10. The system rotameter flow is adjusted to the proper airflow.

11. The rotameter, flow totalizer, and vacuum readings are all recorded on the fresh sample envelope. 
12. The record sample head is tested for leaks.

13. The sample is transported to the laboratory. Before this is accomplished the following is done.

- Dose rate and contamination surveys are performed on the wrapped sample cartridge.

- Any dose readings found are indicated on a signed and dated surveyed-for-shipment sticker that is attached to the outer sample bag.

- The sample is placed in a shielded container, if necessary, so that any surface dose rates are less than the maximum allowable on the Routine Radioactive Shipping Record for the OHP (Operational Health Physics) vehicle.

14. Any applicable sample exchange information is recorded on the Scheduled Radiation Survey Report. Any system discrepancies are reported to the cognizant OHP supervisor or designee, in writing, on a Don't Say It -- Write It (DSI) form.

\subsubsection{Exchanging Record Sample Filters. Record sample filters are} exchanged in accordance with the Health Physics Procedure No. 5.2.2.7, Rev 2, "Operation of Gaseous Effluent Sampling and Monitoring Systems." This procedure is contained in WHC-IP-0692 (WHC 1992g). This section describes the record sample filter exchange process.

If at all possible, record air samples are left running for a full $168 \mathrm{~h}$ (7-day week), to ensure a representative sample.

1. A white air sample envelope is prepared.

2. A 47-mm sample filter is prepared for exchange. The EDP code and the date are written along the outside edge.

3. The following information is recorded in the space provided on the white sample envelope left in the sample cabinet when the record sample was last installed:

- Date

- Time

- HPT's name and payroll number

- Rotameter reading

- Vacuum reading

- Gas-meter totalizer reading

- Timer (counter) reading.

4. The sample holder is opened, the halves of the sample holder are separated, and the sample is inserted into the sample envelope.

5. The sample in the envelope is surveyed for any gross activity levels. Any activity levels are recorded on the back side of the sample envelope. 
6. The record sample holder is inspected for system operability.

7. The record sample timer is reset.

8. The freshly prepared sample filter is applied to the holder screen and the sample holder is reassembled.

9. The following information is recorded in the space provided on the white sample envelope, which is left in the sample cabinet for the next sample exchange:

- EDP code

- Date

- Time

- HPT's name and payroll number

- Rotameter reading

- Vacuum reading

- Gas-meter totalizer reading.

10. The operability inspection is performed again.

11. The sample is prepared for delivery to the 222-S Counting Laboratory.

9.1.1.3 Exchanging Continuous Air Monitor Filters. The CAM filters are exchanged in accordance with the Health Physics Procedure No. 5.2.2.7, Rev 2, "Operation of Gaseous Effluent Sampling and Monitoring Systems." This procedure is contained in WHC-IP-0692 (WHC 1992g). The following section describes the CAM filter exchange process.

1. Operability inspection is performed on the CAM system.

2. Buff colored air sample envelopes are prepared for each CAM in the system.

3. For each CAM, a 47-mm sample filter is prepared for exchange. The location (or sample code number) and date are written along the outside edge.

4. The rotameter reading is recorded in the space provided on the buff envelope that was left in the cabinet on the last sample exchange day.

5. The CAM sample filters are exchanged. The CAMs' rubber " 0 " rings are inspected during the exchange.

6. The required data are entered on the fresh buff sample envelope.

7. The operability inspection is completed.

8. The activity levels of the samples are surveyed and logged on the appropriate air sample log for that facility. If survey results indicate a higher than normal count rate, (as indicated by a 
comparison with the previous week's sample survey results) the CAM sample filters are held for further decay counting or laboratory analyses.

9.1.1.4 Sample Data Examination and Delivery to the 222-S Laboratory. Sample data examination and delivery to the 222-S Laboratory are conducted in accordance with the Health Physics Procedure No. 5.2.2.7, Rev 2, "Operation of Gaseous Effluent Sampling and Monitoring Systems." This procedure is contained in WHC-IP-0692 (WHC 1992g). The following section describes this examination and delivery.

1. All effluent record samples are sent to the cognizant HP field office for data inspection by the HP supervisor (or designee) before they are delivered to the 222-S Laboratory for analyses.

2. The HP supervisor inspects the sample data on each envelope and verifies the accuracy of the following data (listed in the order appearing on the sample envelope).

- EDP Code No.--Must be correct for the listed location.

- Location--Must specify the sample location.

- Date ON--Must indicate the day the sample was installed.

- Time ON--Must indicate the actual time that the sample was installed, not the time that the HPT started to make the inspection/exchange rounds. All the sample envelopes are inspected to ensure that the "ON" times indicate proper chronological order.

- Signature/Payroli No. ON--Must be legible.

- Date OFF--Must indicate the day the sample was removed. Should be a 7-d sample run unless otherwise required (exhauster shutdown, sample system maintenance) or approved by Westinghouse Hanford Environmental Protection (e.g., special sample pull or short or long work week because of a holiday).

- Time OFF--Must indicate the actual time that the sample was removed, not the time that the HPT started the inspection. All the sample envelopes are inspected to ensure that the "OFF" times indicate proper chronological order.

- Signature/Payroll No. OFF--Must be legible.

- Timer OFF--Must indicate $168 \pm 1 \mathrm{~h}$ unless sample interval was shortened because of conditions listed for "DATE OFF."

- Gas Meter/Flow Totalizer $\mathrm{NN}_{3}$ and OFF--Must indicate a total sample flow of 550 to $600 \mathrm{~m}^{3}$ (assuming a nominal $2 \mathrm{ft}^{3} / \mathrm{min}$ 
flow) for the 7-d sample period. For modified sample runs, appropriate values $\left(-81 \mathrm{~m}^{3} / \mathrm{d}\right.$ or $\left.3.4 \mathrm{~m}^{3} / \mathrm{h}\right)$ are used to compensate.

- Rotameter $\mathrm{ON}$ and $\mathrm{OFF}$--The $\mathrm{ON}$ reading must be correct for the sample location as determined by the sample flow rate necessary to maintain isokineticity with the stack flow. The OFF reading should indicate approximately the same flow as the oN reading when allowance for filter restriction is accounted for.

- Vacuum ON and OFF--The ON reading is consistent (not substantially higher than normal) with readings of previous weeks. The OFF reading must be greater than the oN reading.

- Blank Data Spaces--Data must be complete for all equipment installed at that sample location. For installations not incorporating that particular instrument, the applicable data space must be marked $N / A$.

3. The supervisor or designee records the sample data on the Health Physics Effluent Record Sample Log applicable to that EDP code sample location. The HP supervisor initials the completed entry, certifying its correctness.

4. If the above data requirements are not met, the HP supervisor returns the sample envelope to the HPT for correction during the shift the sample was removed. If necessary, the supervisor consults with the HPT that originally installed the sample to resolve the data discrepancy.

5. The HP supervisor documents, in the HP field log book, any substandard sampler system performance noted in the above data examination as follows:

- Gas meter/flow totalizer readings of less than what would be expected from the recorded rotameter reading and total sampling time for the sample interval. Expected readings are calculated by the following formula:

$\left(X \mathrm{ft}^{3} / \mathrm{min} \times .0283 \mathrm{~m}^{3} / \mathrm{ft}^{3} \times Y \mathrm{~h}\right.$ sampled $\left.\times 60 \mathrm{~min} / \mathrm{h}\right) \pm 10 \%$

- Timer readings of less than $168 \pm 1 \mathrm{~h}$ when stack shutdown or modified sample exchange has not occurreu.

- Excessively high vacuum "ON" readings.

6. The HP supervisor schedules the necessary maintenance (replacement or calibration) of the flow totalizer or repair of the sampler system if the measured volume of the sample averages less than $400 \mathrm{~m}^{3} /$ wk for three successive sample periods. 
- Environmental Protection is notified of the above discrepancy when discovered and of the date and time that calibration/repairs are compieted.

- Replacement/calibration of the flow totalizer requires a special notation in the gas meter totalizer box on the new sample envelope, such as "new gas meter on," the installed reading, and the reason for the sample exchange.

7. All applicable "Sample Chain of Custody" documentation is completed as required by the 222-S Laboratory.

8. The samples are packaged for shipment and transported to the 222-S Laboratory.

9. The samples are checked into the laboratory for counting in accordance with their sample check-in or "Chain of Custody" requirements. Any required documentation is completed and copies are returned to the HP field office for reference.

9.1.1.5 Laboratory Sample Analysis Instructions. Each effluent sample type is assigned a specific number by the Environmental Protection group. This number is used to track the analysis of each stream. The codes for the airborne effluent streams at the 242-A Evaporator are shown in Table 9-1.

Table 9-1. Sample Electronic Data Processing Codes.

\begin{tabular}{|l|l|l|}
\hline EDP Code & \multicolumn{1}{|c|}{ Sample type } & \multicolumn{1}{c|}{ Sample location } \\
\hline E645 & Record sampler & 296-A-21 Building ventilation \\
\hline E646 & Alpha CAM & 296-A-21 Building ventilation \\
\hline E991 & Beta/gamma CAM & 296-A-21 Building ventilation \\
\hline E643 & Record sampler & 296-A-22 Vessel ventilation \\
\hline E001 & Silver zeolite cartridge & 296-A-22 Vessel ventilation \\
\hline E002 & Silver zeolite cartridge & $296-A-22$ Vessel ventilation \\
\hline E465 & Alpha CAM & 296-A-22 Vessel ventilation \\
\hline E642 & Beta/gamma CAM & $296-A-22$ Vessel ventilation \\
\hline
\end{tabular}

It is also the responsibility of the Environmental Protection group to supply the analytical laboratory with appropriate instruction concerning which analyses should be conducted for each sample. These instructions are updated annually. For 1991 the instructions to the laboratories were as follows:

- To analyze the record sampler in the building ventilation stack $(296-\mathrm{A}-21)$ for ${ }^{239} \mathrm{Pu},{ }^{240} \mathrm{Pu},{ }^{89} \mathrm{Sr},{ }^{90} \mathrm{Sr}$, gross alpha, and gross beta

- To analyze the record sampler in the vessel ventilation stack (291-A-22) for ${ }^{89} \mathrm{Sr}^{\circ},{ }^{90} \mathrm{Sr}$, gross alpha, and gross beta 
- To analyze the silver zeolite cartridges (both) in the vessel
ventilation stack $(291-\mathrm{A}-22)$ for ${ }_{129} \mathrm{I},{ }_{131} \mathrm{I},{ }^{125} \mathrm{Sb},{ }^{113} \mathrm{Sn},{ }^{103} \mathrm{Ru}$, and ${ }^{106} \mathrm{Ru}$.

9.1.1.6 Laboratory Analysis. This section provides a brief description of what becomes of the various sample types on receipt at the laboratory.

The record sample is designated as the sample of record. This sample is held for $7 \mathrm{~d}$ in the laboratory to allow the short-lived radioisotopes to decay. These samples are then counted for alpha and beta readings. These readings are reported to the Environmental Protection group and the Health and Safety group responsible for the facility. These samples are then stored. Once each quarter, these samples are gathered, dissolved, and an isotopic analysis is performed. The results of these analyses are reported to the Environmental Protection group.

The CAM samples are not treated as record samples unless requested. Only the CAM filters from the room-monitoring CAMs are sent to the laboratory. Those from the stacks are monitored by the Health Physics group.

The silver zeolite samples are not held either. They are analyzed and reported the next day to the Environmental Protection group.

9.1.1.7 Laboratory Procedures. The analytical laboratory procedures will be supplied in the 222-S Laboratory FEMP. In general, the following procedures apply:

- L0-150-133 - Directs holding specific samples for $7 \mathrm{~d}$ to allow short-lived radionuclides to decay

- LA-288-101 - The procedure for analyzing for silver zeolite cartridges

- LA-508-110 - The procedure for counting air samples

- LA-508-106 - The procedure for reducing/computerizing data.

The following procedures are also used on selected stack air filter samples composited on a quarterly basis; the analyses depends on the sample point:

\begin{tabular}{|c|c|c|}
\hline $\begin{array}{l}\text { LA-549-134 } \\
\text { LA-548-142 } \\
\text { LA-549-112 } \\
\text { LA-220-103 } \\
\text { LA-943-123 } \\
\text { LA-613-111 } \\
\text { LA-943-123 }\end{array}$ & $\begin{array}{l}- \\
- \\
-\end{array}$ & $\begin{array}{l}\text { Compositing } \\
\text { Gamma energy analysis } \\
\text { Dissolution } \\
89 / 90 \mathrm{Sr} \\
{ }^{239 / 240} \mathrm{Pu} \\
{ }^{147} \mathrm{Pm} \\
{ }^{241} \mathrm{Am} \\
\text { Uranium. }\end{array}$ \\
\hline
\end{tabular}


The following procedures are also available for nonradionuclide analyses:

$\begin{array}{ll}\text { - } & \text { LA-533-101 - Nitrate } \\ \text { - LA-344-105 - Total organic carbon. }\end{array}$

9.1.1.8 Laboratory Detection Limits For Airborne Radionuclide Releases. Table 9-2 provides the minimum quantifiable activities for specific radionuclides as measured in air samples that are changed weekly.

Assumptions used to develop these limits are as follows:

- Airflow through the sampler is $2 \mathrm{ft}^{3} / \mathrm{min}$ and the samples are exchanged weekly

- Plutonium, americium, and strontium are measured from particulate filters

- Iodine components require specific absorption cartridges (e.g., silver impregnated zeolites), and the entire cartridge is counted.

Table 9-2. Radionuclide Detection Limit.

\begin{tabular}{|l|c|}
\hline \multicolumn{1}{|c|}{ Radionuclide } & $\begin{array}{c}\text { Minimum concentration } \\
\left(\mathrm{pC} i / \mathrm{cm}^{3}\right)\end{array}$ \\
\hline${ }^{239},{ }^{240} \mathrm{Pu}$ & $1.0 \mathrm{E}-08$ \\
\hline${ }^{249} \mathrm{Am}$ & $2.0 \mathrm{E}-08$ \\
\hline${ }^{90} \mathrm{Sr}$ & $3.0 \mathrm{E}-08$ \\
\hline${ }^{129} \mathrm{I}$ & $2.0 \mathrm{E}-06$ \\
\hline${ }^{131} \mathrm{I}$ & $1.0 \mathrm{E}-07$ \\
\hline${ }^{125} \mathrm{Sb}$ & $1.0 \mathrm{E}-06$ \\
\hline${ }^{113} \mathrm{Sn}$ & $2.0 \mathrm{E}-07$ \\
\hline${ }^{103} \mathrm{Ru}$ & $1.0 \mathrm{E}-07$ \\
\hline${ }^{106} \mathrm{Ru}$ & $1.0 \mathrm{E}-06$ \\
\hline
\end{tabular}

\subsubsection{Steam Condensate Sampling Process}

Plant Operating Procedure T0-630-040, "Sample/Drain 242-A Steam Condensate," (WHC 1990h) provides instructions for sampling the 242-A steam condensate from the sample receiver tank $\mathrm{RCl}$ and filling and draining the steam condensate basins. After the sampling is complete, the samples are taken to the 222-S Environmental Laboratory where they are checked for total alpha and total beta. If the total alpha is less than $1.0 \times 10^{-03} \mu \mathrm{Ci} / \mathrm{L}$ and the total beta is less than $3.0 \times 10^{-04} \mu \mathrm{Ci} / \mathrm{L}$, the condensate is drained to the 216-B-3 Pond. The following is a brief discussion of this process. 
Steam condensate samples are taken as soon as possible after one retention basin is filled and the flow is diverted to another retention basin. These samples are taken from the RCl sampler located on the second level of the condenser room. Tank Farm Plant Engineering may request additional samples.

If the 242-A Evaporator is operating, a 2- $L$ volume of composite sample is taken ( 2 each in $1-L$ bottles). If the process is shut down or is shutting down, a 4-L volume of compusite sample is taken (4 each in $1-L$ bottles). One additional liter is taken for a process control sample.

The sample bottles are checked for contamination using a beta/gamma radiation counter. Sample numbers for the ASC composite sample and ASC process control sample are obtained from the Laboratory Customer Computer System (LCCS) at the 242-A Evaporator. Tags are attached to each sample bottle. The following information is placed on the tags:

- Date: The day and year

- Time: The time the sample was taken

- Sample number:

- Type of sample: Process control or composite

- Retention basin sampled (if applicable): The number of the basin

- Amount of sample: Number of liters.

Next the 242-A Sample Log Data Sheet is completed with all the same information except the amount of sample. The samplers are surveyed by the HPTs and released for delivery to the 222-S Laboratory.

The results of the analysis are obtained from the 222-S Laboratory or from the LCCS. The results and the time of day they were obtained are recorded in the Sample Log Data Book. If the results are below the specified limits, the retention basin is drained.

The retention basin may be sampled at the direction of supervision.

\subsubsection{Cooling Water Sampling Process}

A procedure is being written that will provide instructions for sampling the used cooling water from the 242-A Evaporator via the receiver tank RC2. When the evaporator is operating, cooling water is sampled daily to ensure that the activity is below limits and that the condenser tubes are not leaking. These limits are total alpha less than $1.0 \times 10^{-03} \mu \mathrm{Ci} / \mathrm{L}$ and total beta less than $3.0 \times 10^{-04} \mu \mathrm{C} / \mathrm{L}$. The cooling water is discharged to the 216-B-3 Pond. Any detected contamination requires a full evaporator shutdown. The following is a brief discussion of the sampling process.

The cooling water is sampled daily from the RC2 sampler system located on the first floor of the condenser room. A $250-\mathrm{mL}$ sample bottle is filled with the ACW composite sample and a $1-L$ bottle is filled with the ACW sample. The bottles are surveyed with a Geiger-Müeller instrument. Unique sample 
numbers are obtained from the LCCS in the 242-A control room. Labels are filled out and affixed to each bottle at the time of sampling. The following information is completed on the tags:

- Date: the day, month, and year

- Time: the time of day that the sample was taken

- Sample identification number:

- Person collecting the sample

- Type of sample: ACW composite or ACW.

The HPTs are requested to survey the samples to rolease them for delivery to the 222-S Laboratory. The released sample containers are bagged and rebagged. The samples are placed in a cooler containing ice. The cooler becomes part of the sampling package and has tamper evident tape placed over its opening.

A logbook containing information pertinent to sampling activities is maintained. Entries are to contain the sample point, sample number, container volumes, date \& time of collection, field measurements, any field observations, transportation information, and signatures of personnel responsible for observations. The Sampling and Mobile Laboratory will control and maintain the logbook.

\subsubsection{Sample Analysis for 242-A Liquid Effluents}

The constituents to be analyzed are detailed in the sample analysis plans (WHC 1992a, 1992b) for the two liquid streams. The constituents to be analyzed are listed in Table 9-3. The analyte list is based on 40 CFR 264, Appendix IX and Table A-1 of WHC-SD--QAPP-011 REV.1, Liquid Effluent Sampling Quality Assurance Project Plan (QAPjP) (WHC 1992C). Additional analyses have been added, based on permitting requirements. Quality assurance objectives including the analytical method, precision, accuracy, and completeness are detailed in the QAPJP (WHC 1992C).

\subsection{SAMPLING AND DATA CHAIN OF CUSTODY}

Chain of custody on environmental samples is accomplished via the Health Physics procedure No. 6.6.1.7, Rev 0, "Chain of Custody Procedures, " found within WHC-IP-0692 (WHC 1992g). This procedure is not specifically required to be followed by the procedures used to exchange the 242-A Evaporator facility's effluent stream samples. This procedure is, however, followed for changing the particulate and nonparticulate air sample filters for environmental samplers, or, in other words, the samples taken at the various ambient air sampling stations set up in the 100 and 200 areas at the Hanford Site.

The following definition applies.

A sample is in a person's "custody" if:

(i) It is in one's actual possession 
Table 9-3. Sample Analyte List for 242-A Liquid Effluents.

\begin{tabular}{|c|c|}
\hline Analytes & Analys is method \\
\hline Total methods by ICP & $\begin{array}{l}\text { EPA Method } 3010 / 6010 \text { - analyte list as specified in } \\
\text { the method. Samples will be unfiltered unless } \\
\text { turbid. }\end{array}$ \\
\hline $\begin{array}{l}\text { Total metals by graphite furnace atomic absorption: } \\
\text { antimony } \\
\text { arsenic } \\
\text { chronium } \\
\text { beryllium } \\
\text { cadmium } \\
\text { lead } \\
\text { thallium } \\
\text { mercury }\end{array}$ & $\begin{array}{l}3020 / 7041 \\
3020 / 7060 \\
3020 / 7191 \\
3020 / 7091 \\
3020 / 7131 \\
3020 / 7421 \\
3020 / 7841 \\
3020 / 7470 \text { (cold vapor) }\end{array}$ \\
\hline $\begin{array}{l}\text { Volatile organics by gas chromatography - mass } \\
\text { spectroscopy (GC-MS) }\end{array}$ & $\begin{array}{l}\text { EPA Method } 8240 \text { (gc/ms - capillary colum lpurge and } \\
\text { trap]) include all analytes listed in the method. }\end{array}$ \\
\hline $\begin{array}{l}\text { Semi-Volatile organics by gas chromatography - mass } \\
\text { spectroscopy }\end{array}$ & $\begin{array}{l}\text { EPA Method } 8270 \text { (gc/ms - capillary column) includes } \\
\text { all analytes listed in the method. }\end{array}$ \\
\hline Polychlorinated biphenyls (PCBS) gas chromatography & $\begin{array}{l}\text { EPA Method } 3510 / 8080 \text { or } 3520 / 8080 \cdot \text { clean-up via } \\
\text { Method } 3620\end{array}$ \\
\hline $\begin{array}{l}\text { Total recoverable oil and grease (gravimetric, } \\
\text { separatory fummel extraction) }\end{array}$ & EPA Method 9070 \\
\hline $\begin{array}{l}\text { Total organic carbon (oxidation, infrared, or flame } \\
\text { ionization detector) }\end{array}$ & EPA Method 9060 \\
\hline $\begin{array}{l}\text { Total organic halogens (carbon adsorption, } \\
\text { micocoulometric - titration detector) }\end{array}$ & EPA Method 9020 \\
\hline Total phenols & EPA Method 420 \\
\hline Common anions by column chromatography & $\begin{array}{l}\text { EPA Method } 9056 \text { of } 300 \text { series. All analyte } \\
\text { specififed by this method are targeted. }\end{array}$ \\
\hline Amenable cyanide & \\
\hline Ammoni a & EPA Method 350.5 \\
\hline $\begin{array}{l}\text { Secondary water quality parameters and other } \\
\text { parameters of interest } \\
\text { pH } \\
\text { Specific conductance/total dissolved solids } \\
\text { Chemical oxygen demand } \\
\text { Biological oxygen demand } \\
\text { Alkal inity } \\
\text { Fecal col iforms } \\
\text { Total col iform }\end{array}$ & $\begin{array}{l}\text { EPA Method } 9040 \\
\text { EPA Method } 9040 \\
\text { EPA Method } 410 \\
\text { EPA Method } 405.1 \\
\text { EPA Method 305.1 } \\
\text { Method SM 908C } \\
\text { Method SM 908A }\end{array}$ \\
\hline $\begin{array}{l}\text { Radiochemical analysis } \\
28 \uparrow_{\mathrm{al}} \text { alpha and beta } \\
106 \mathrm{Pu} \text { and }{ }^{137} \mathrm{Cs} \\
90 \mathrm{Ru}\end{array}$ & $\begin{array}{l}\text { EPA Method } 9310(\mathrm{SH}-846) \\
\text { EPA Method } 00-07 \\
\text { Gamna spectrometry } \\
\text { EPA Method SR-05 }\end{array}$ \\
\hline
\end{tabular}


(ii) It is in one's view, after being in one's physical possession

(iii) It is in one's physical possession and then locked up so that no one can tamper with it

(iv) It is kept in a secured area, restricted to authorized personnel only.

\subsubsection{Chain of Custody Sample Collection, Handling, and Identification}

The number of persons involved in collecting and handling samples is kept to a minimum. Field records are completed at the time the sample is collected and are signed or initialed, including the date and time, by the sample collector(s). Field records contain the following information:

- Unique sampling or log number

- Date and time

- Source of sample (including name, location, and sample type)

- Preservative used

- Analysis required

- Name of collector(s)

- Pertinent field data (e.g., pH and chlorine residual)

- Serial numbers on seals and transportation cases.

One member of the sampling team is appointed field custodian. Samples are turned over to the field custodian by the team members who collected the samples. The field custodian documents each transaction and the sample remains in his/her custody until it is shipped to the laboratory.

Each sample is identified by affixing either a pressure-sensitive gummed label or a standardized tag on the container. This label contains the sample identification number, data and time of collection, source, preservative used (if applicable), analysis required, and the collector's initials. If a label is not available, the same information is recorded on the sample container legibly and with waterproof ink.

The sample container is then placed in a transportation case, along with the chain of custody record form, pertinent field records, and analysis request form as needed. The transportation case is sealed or locked. The use of a transportation case that is sealed or locked eliminates the need for close control of individual samples. However, on those occasions when the use of a chest is inconvenient, the collector seals the cap of the individual sample container in a way that any tampering would be easy to detect.

When samples are composited over a period of time, unsealed samples are transferred from one custodian to the next. The transferring custodian (transferor) lists the samples and the oncoming custodian (transferee) signs the 1ijt. The transferee either transfers the samples to another custodian or delivisrs them to a laboratory person, who signs for the samples. 


\subsubsection{Transfer of Custody and Shipment}

When samples are transferred, the transferee must sign and record the date and time on the chain of custody record. Custody transfers made to a sample custodian in the field account for each sample (samples may be transferred as a group). Each person who takes custody must fill in the appropriate section of the chain of custody record. To minimize the custody records, the number of custodians in the chain of possession is minimized.

The field custodian is responsible for properly packaging and dispatching samples to the appropriate laboratory. This responsibility includes completing, dating, and signing the appropriate portion of the chain of custody record.

All packages sent to the laboratory are accompanied by the chain of custody record and other pertinent forms. A copy of these forms is retained by the originating office.

Samples to be shipped are packed so as not to break and the package sealed or locked so that any tampering can be readily detected.

\subsubsection{U.S. Department of Energy Analytical and Laboratory Guidelines}

The analytical and laboratory procedures for the FEMP activities are identified in the Quality Assurance Project Plan for the Facility Effluent Monitoring Plan Activities (WHC-EP-0446-1) (WHC 1992f). General requirements for laboratory procedures, data analyses, and statistical treatment are addressed in the QAPJP.

Additional procedural references also are included in the 222-S Laboratory FEMP.

The 222-S Laboratory on the Hanford Site has one program plan and two project plans to address applicable quality requirements related to sample analysis. These plans are as follows:

- WHC-SD-CP-QAPP-003, Quality Assurance Program P7an for the Chemical Analysis of Environmental Samples (Moss 1990)

- WHC-SD-CP-QAPP-001, Analytical Chemistry Services Laboratories Quality Assurance Plan (Svancara 1991)

- WHC-SD-CP-QAPP-002, Quality Assurance Project Plan for the Chemical Analysis of Highly Radioactive Mixed Waste Samples in Support of Environmental Activities on the Hanford Site (WHC 1989d).

The elements in Tables 9-1 and 9-2 are identified in Environmental Regulatory Guide for Radiological Effluent Monitoring and Environmental Survei?lance (DOE 1991). These elements also are addressed in the 222-S Laboratory FEMP. 
The RCRA protocol liquid effluent sampling, associated with the LES, is not part of the FEMPs. The $Q A$ requirements for the sampling analys is $p l a n s$ associated with the LES are identified in the latest version of WHC-SD-WM-QAPP-011, Rev 1, Liquid Effluent Sampling Quality Assurance Project Plan (WHC 992C). Sampling will be performed according to the SAP (see Section 7.1). The SAPs have been prepared pursuant to the Tri-Party Agreement (Ecology et al. 1991) and are available for review. 
Table 9-4. Laboratory Procedures.

\begin{tabular}{|c|c|}
\hline Element & Documentation \\
\hline Sample identification system & To be provided when complete \\
\hline Procedures preventing crosscontamination & $\begin{array}{l}\text { Contained in 222-s Laboratory Analytical } \\
\text { Procedures, (ident ified in AAP jP WHC-EP-0446 } \\
\text { Table 8-1) }\end{array}$ \\
\hline Documeritation of methods & $\begin{array}{l}\text { Contained in 222-s Laboratory Analytical } \\
\text { Procedures, (identified in QAP JP WHC-EP-0446 } \\
\text { Table 8-1) }\end{array}$ \\
\hline Gamma emitting radionuclides & $\begin{array}{l}\text { Contained in } 222-5 \text { Laboratory Analytical } \\
\text { Procedures, } \\
\text { Table } 8-1 \text { ) }\end{array}$ \\
\hline Calibration & $\begin{array}{l}\text { Contained in } 222-5 \text { Laboratory Analytical } \\
\text { Procedures, }{ }_{1} \text { (ident if ied in QAP jP HHC-EP-0446 } \\
\text { Table 8-1) }\end{array}$ \\
\hline Handling of samples & $\begin{array}{l}\text { Contained in } 222-5 \text { Laboratory Analytical } \\
\text { Procedures, }{ }_{1} \text { (identified in OAP jP WHC-EP-0446 } \\
\text { Table 8-1) }\end{array}$ \\
\hline Analys is method and capabilities & $\begin{array}{l}\text { Contained in 222-s Laboratory Analytical } \\
\text { Procedures, (identified in OAP jP WHC-EP-0446 } \\
\text { Table 8-1) }\end{array}$ \\
\hline Gross alpha, beta, and gamma measurements & $\begin{array}{l}\text { Contained in 222-5 Laboratory Analytical } \\
\text { Procedures, }{ }_{1} \text { (ident ified in OAP jP WHC-EP-0446 } \\
\text { Table 8-1) }\end{array}$ \\
\hline Direct gamma-ray spectrometry & $\begin{array}{l}\text { Contained in 222-S Laboratory Analytical } \\
\text { Procedures, }{ }_{1} \text { (ident ified in QAP jP WHC-EP-0446 } \\
\text { Table } 8-1 \text { ) }\end{array}$ \\
\hline Beta counters & $\begin{array}{l}\text { Contained in 222-s Laboratory Analytical } \\
\text { Procedures, }{ }_{1} \text { (ident ified in QAP jP WHC-EP-0446 } \\
\text { Table 8-1) }\end{array}$ \\
\hline Alpha-energy analysis & $\begin{array}{l}\text { Contained in 222-s Laboratory Analytical } \\
\text { Procedures, (ident ified in QAP JP WHC-EP-0446 } \\
\text { Table } 8-1 \text { ) }\end{array}$ \\
\hline Radiochemical separation procedures & $\begin{array}{l}\text { Contained in 222-s Laboratory Analytical } \\
\text { Procedures, (identified in QAP JP WHC-EP-0446 } \\
\text { Table } 8-1 \text { ) }\end{array}$ \\
\hline Reporting of results & $\begin{array}{l}\text { Contained in 222-S Laboratory Analytical } \\
\text { Procedures, (identified in QAP JP WHC-EP-0446 } \\
\text { Table } 8-1 \text { ) }\end{array}$ \\
\hline Counter calibration & $\begin{array}{l}\text { Contained in 222-S Laboratory Analytical } \\
\text { Procedures, } \text { (ident ified in QAP JP WHC-EP-0446 }_{\text {Table B-1) }}\end{array}$ \\
\hline Intercalibration of equipment and procedures & $\begin{array}{l}\text { Contained in } 222-5 \text { Laboratory Analytical } \\
\text { Procedures, (identified in QAP JP WHC-EP-0446 } \\
\text { Table B-1) }\end{array}$ \\
\hline Counter background & $\begin{array}{l}\text { Contained in } 222-5 \text { Laboratory Analytical } \\
\text { Procedures, } \text { (ident ified in QAP jP, WHC-EP-0446 }_{\text {Table } 8-1 \text { ) }}\end{array}$ \\
\hline Quality assurance & $\begin{array}{l}\text { Contained in 222-S Laboratory Analyt ical } \\
\text { Procedures, } \text { (ident ified in QAP JP, WHC-EP-0446 } \\
\text { Table } 8-1 \text { ) }\end{array}$ \\
\hline
\end{tabular}

QAPjP = Quality Assurance Project Plan.

WHC. 1992, quality Assurance Froject Plan for Facility Effluent Monitoring Plan Activities, WHC-EP-0446, Westinghouse Hanford Company, Richland, Washington. 
Table 9-5. Data Analyses and Statistical Treatment.

\begin{tabular}{|l|l|}
\hline \multicolumn{1}{|c|}{ Element } & \multicolumn{1}{|c|}{ Documentation } \\
\hline $\begin{array}{l}\text { Summary of data and statistical treatment } \\
\text { requirements }\end{array}$ & $\begin{array}{l}\text { Contained in 222-S Laboratory } \\
\text { Analytical Procedures (ident ified } \\
\text { in QAPjP, WHC-EP-0446 Table 8-1) }\end{array}$ \\
\hline $\begin{array}{l}\text { Variability of effluent and environmental } \\
\text { data }\end{array}$ & $\begin{array}{l}\text { Contained in 222-S Laboratory } \\
\text { Analytical Procedures (ident ified } \\
\text { in QAPjP, WHC-EP-0446 Table 8-1) }\end{array}$ \\
\hline $\begin{array}{l}\text { Summarization of data and testing for } \\
\text { outliers }\end{array}$ & $\begin{array}{l}\text { Contained in 222-S Laboratory } \\
\text { Analyt ical Procedures (identified } \\
\text { in QAPjP, WHC-EP-0446 Table 8-1) }\end{array}$ \\
\hline $\begin{array}{l}\text { Treatment of significant figures } \\
\text { Parent-decay product relationships }\end{array}$ & $\begin{array}{l}\text { Contained in 222-S Laboratory } \\
\text { Analyt ical Procedures (identified } \\
\text { in QAPjP, WHC-EP-0446 Table 8-1) }\end{array}$ \\
\hline $\begin{array}{l}\text { Comparisons to regulatory or } \\
\text { administrative control standards and } \\
\text { control data }\end{array}$ & $\begin{array}{l}\text { Contained in 222-S Laboratory } \\
\text { in QAPjP, WHC-EP-0446 Table 8-1) }\end{array}$ \\
\hline $\begin{array}{l}\text { Quality assurance } \\
\text { Analytical Procedures (identified } \\
\text { in QAPjP, WHC-EP-0446 Table 8-1) }\end{array}$ \\
\hline $\begin{array}{l}\text { Contained in 222-S Laboratory } \\
\text { Analytical Procedures (identified } \\
\text { in QAPjP, WHC-EP-0446 Table 8-1) }\end{array}$ \\
\hline
\end{tabular}

${ }^{1}$ WHC, 1992, Quality Assurance Project Plan for Facility Effluent Monitoring Plan Activities, WHC-EP-0446, Westinghouse Hanford Company, Richl and, Washington. 
WHC-EP-0466-1

This page intentionally left blank. 


\subsection{NOTIFICATIONS AND REPORTING}

Notifications and reporting of specific events related to environmental releases and/or events involving effluents and/or hazardous materials shall be made in accordance with DOE Orders 5400.1 (DOE 1990a) and 5000.3A.

Implementation of the orders is accomplished via Management Requirements and Procedures Manual (MRP) WHC-CM-1-3, 5.14, (WHC 1992h). Specific implementation, where required, is included in the appropriate facility's "Occurrence Categorization, Notification and Reporting" procedure. Implementation of environmental limits and requirements is found in the ECM, WHC-CM-7-5 (WHC 1992i).

\subsection{REQUIREMENTS}

\subsubsection{Occurrence Identification and Immediate Response}

Each employee shall identify events and conditions and shall notify management promptly of such occurrences by

- Calling 811 if immediate help such as fire, ambulance, or patrol is required

- Calling 3-3800 (the Patrol Operations Center) if assistance other than fire, ambulance, or patrol is required

- Notifying, after requesting necessary outside assistance, tne supervisor, who shall notify the facility manager, the building emergency director, and the Occurrence Notification Center $(6-2900)$.

Operations personnel shall take appropriate immediate action to stabilize or return the facility/operation to a safe condition. The oversight organizations shall notify their RL counterparts of the event after receiving notifications from, and discussing the event with, the facility manager.

\subsubsection{Occurrence Categorization}

Occurrences (environmental) shall be categorized as soon as practical using the following specific criteria for radioactive and hazardous materials release. These categorizations should be made within $2 \mathrm{~h}$ of identification. occurrences shall be categorized by their seriousness. If categorization is not clear, the occurrence initially shall be categorized at the higher level being considered. The occurrence categorization then shall be either evaluated, maintained, or lowered as information becomes available. 


\subsection{OCCURRENCE CATEGORIZATION}

\subsubsection{Radioactive Releases}

\subsubsection{Emergency.}

- Any release of radioactive material to controlled or uncontrolled areas in concentrations which, if averaged over a 24-h period, would exceed 5,000 times the DCG.

- Any release of radioactive material offsite that is not a normal monitored release and could reasonably be expected to result in an annual dose or dose commitment greater than 500 mrem to any member of the general population.

10.2.1.2 Unusual Occurrence.

- Release of radionuclide material that violates environmental requirements in permits, regulations, or DOE standards as determined by Westinghouse Hanford Environmental Protection.

- Any other release below emergency levels that requires immediate reporting to regulatory agencies or triggers outside agency specific action levels as determined by Westinghouse Hanford Environmental Protection.

\subsubsection{Off-Normal.}

- Any release of radionuclides that is not a normally monitored release.

- Any discovery of radionuclides where they are not expected (e.g., storm sewers, sanitary sewers, etc.) and for which no immediate explanation is available.

- Any statistically significant increase in normally monitored releases of radionuclides to an uncontrolled area.

- Any release of radionuclides that will be reported to an outside agency (excluding normal reporting) but is not classified as an unusual occurrence.

- Any controlled and monitored gaseous radionuclide release exceeding a Westinghouse Hanford administrative control value on an annual basis or 10 times the administrative control value on a weekly basis.

- Any controlled and monitored (instantaneous) gaseous radionuclide release exceeding 5,000 times the DCG during any 4-h period. 
- Any controlled and monitored liquid radionuclide releases exceeding the Westinghouse Hanford-established administrative control value on an annual basis or two times that value on a monthly or weekly basis.

- Any controlled and monitored liquid radionuclide release exceeding 5,000 times DCG instantaneously.

\subsubsection{Hazardous Substances Releases}

\subsubsection{Emergency.}

- Any actual or potential release of material to the environment that results in or could result in significant offsite consequences (i.e., need to relocate people, major wildlife kills, woodland degradation, aquifer contamination, or the need to secure downstream water supply intakes, etc.).

\subsubsection{Unusual Occurrence.}

- Release of a hazardous substance, regulated pollutant, or oil that exceeds a reportable quantity, federal permits, DOE standards, or levels requiring immediate reporting to outside agencies as determined by Westinghouse Hanford Environmental Protection.

\subsubsection{3 offnormal.}

- Any unmonitored release of hazardous substance or regulated pollutant as determined by Westinghouse Hanford Environmental Protection.

- Any statistically significant increase of hazardous substance in normally monitored releases.

- Any discovery of toxic or hazardous substance where it is not expected.

- Any release of hazardous substance or oil that is not classified as an unusual occurrence but will be reported to outside agencies (excluding normal reporting) as determined by Westinghouse Hanford Environmental Protection.

\subsubsection{Discovery of Radioactive or Hazardous Material \\ Contamination Due to U.S. Department of Energy Operations}

\subsubsection{Emergency.}

- Discovery of contamination that could result in significant consequences (i.e., exceeding safe exposure limits to workers or public). 


\subsubsection{Unusual Occurrence.}

- Discovery of offsite contamination due to DOE operations that does not represent an immediate threat to the public.

- Any discovery of groundwater contamination not previously known or suspected.

\subsubsection{Off-Normal.}

- Discovery of any onsite contamination that is not previously known or expected and is attributable to DOE operations.

\subsubsection{Agreement/Compliance Activities}

\subsubsection{Unusual Occurrence.}

- Any agreement, compliance, remediation, permit-mandated activity, or notification received fron a relevant regulatory agency specifying that a site plan is not satisfactory, or that a site is considered not to be in compliance with schedules or requirements.

- Any occurrence under any agreement or compliance area that requires notification of an outside agency within $4 \mathrm{~h}$ or less, or triggers an outside regulatory agency action level, or otherwise indicates specific interest/concern from such agencies.

\subsubsection{Off-Normal.}

- Any occurrence under any agreement of compliance area that will be reported to outside agencies in a format other than routine monthly or quarterly reports.

- Any changes to existing agreements or permit-mandated activities.

- Development of new agreements or permit-mandated activities. 


\subsection{INTERFACE WITH THE OPERATIONAL ENVIRONMENTAL SURVEILLANCE PROGRAM}

\subsection{DESCRIPTION}

The sitewide Environmental Monitoring Plan (EMP), as described in the FEMP management plan (WHC 1991d), consists of two distinct but related components: environmental surveillance conducted by PNL and effluent monitoring conducted by Westinghouse Hanford. The responsibilities for these two portions of the EMP are delineated in a Memorandum of Understanding (PNL/WHC 1989). Environmental surveillance, conducted by PNL, consists of surveillance of all environmental parameters to demonstrate compliance with regulations. Effluent monitoring includes both in-line and facility effluent monitoring, as well as near-field (near-facility) operational environmental monitoring. Projected EDEs, reported in this FEMP, are the products of inline effluent monitoring. Near-field monitoring is required by Part 0 , "Environmental Monitoring," Environmental Compliance Manual (WHC 1992i), and procedures are described in Operational Environmental Monitoring (WHC 1988C).

\subsection{PURPOSE}

The purpose of near-field (operational environmental) monitoring is to determine the effectiveness of environmental controls in preventing the unplanned spread of contamination from facilities and sites operated by Westinghouse Hanford for DOE. Effluent monitoring and reporting, monitoring of surplus and waste management units, and monitoring near-field environmental media are, therefore, conducted by Westinghouse Hanford for the purposes of: controlling operations, determining the effectiveness of facility effluent controls, measuring the adequacy of containment at waste transportation and disposal units, detecting and monitoring upset conditions, and evaluating and upgrading effluent monitoring capabilities.

\subsection{BASIS}

Near-field environmental surveillance is conducted to (1) monitor employee protection; (2) monitor environmental protection; and (3) ensure compliance with local, state, and federal regulations. Compliance with parts of DOE Orders 5400.1, General Environmental Protection Program (DOE 1990a); 5400.5 , Radiation Protection of the Public and the Environment (DOE 1990b); 5484.1, Protection, Safety, and Health Protection Information Reporting System (DOE 1981); 5820.2A, Radioactive Waste Management (DOE 1988); and DOE/EH-0173T, Environmental Regulatory Guide for Radiological Effluent Monitoring and Environmental Surveillance (DOE 1991), are addressed through this activity.

\subsection{MEDIA SAMPLED AND ANALYSES PERFORMED}

Procedure protocols for sampling, analysis, data handling, and reporting are specified in WHC-CM-7-4 (WHC 1988C). Media include ambient air, surface water, groundwater, external radiation dose, soil, sediment, vegetation, and 
animals at or near active and inactive facilities and/or waste sites.

Parameters monitored include the following, as needed: $\mathrm{pH}$, water temperature, radionuclides, radiation exposure, and hazardous constituents. Animals that are not contaminated, as determined by a field instrument survey, are released at the capture location.

\subsection{LOCATIONS}

Samples are collected from known or suspected effluent pathways (e.g., dowriwind of potential releases, liquid streams, or proximal to release points). To avoid duplication, Westinghouse Hanford relies on existing sample locations where PNL has previously established sample sites (e.g., air samplers in the 300 Area). There are 38 air samplers ( 4 in the 100 Area and 34 in the 200/600 Areas), 35 surface water sample sites (22 in the 100 Area and 13 in the 200/600 Areas), 110 groundwater monitoring wells (20 in the 100 Area, 89 in the 200/600 Areas, and 1 in the 300/400 Areas), 299 external radiation monitor points [182 survey points and 41 thermoluminescent dosimeter (TLD) sites in the 100 Area, 61 TLD sites in the 200/600 Areas, and 15 TLD sites in the 300/400 Areas], 157 soil sample sices (32 in the 100 Area, 110 in the 200/600 Areas, and 15 in the 300/400 Areas), and 95 vegetation sample sites (40 in the 100 Area, 40 in the 200/600 Areas, and 15 in the $300 / 400$ Areas). Animal samples are collected at or near facilities and/or waste sites. Specific locations of sample sites are found in WHC-CM-7-4 (WHC 1988c).

Additionally, surveys to detect surface radiological contamination, scheduled in WHC-CM-7-4 (WHC 1988C), are conducted near and on liquid waste disposal sites (e.g., cribs, trenches, drains, retention basin perimeters, pond perimeters, and ditch banks), solid waste disposal sites (e.g., burial grounds and trenches), unplanned release sites, tank farm perimeters, stabilized waste disposal sites, roads, and firebreaks in the operations areas. There are 391 sites in the operations areas (100 in the 100 Area, 273 in the $200 / 600$ Areas, and 18 in the 300/400 Areas) where radiological surveys are conducted.

\subsection{PROGRAM REVIEW}

The near-field (operational environmental) monitoring program will be reviewed at least annually to determine that the appropriate effluents are being monitored and that the monitor locations are in positions that best determine potential releases.

\subsection{SAMPLER DESIGN}

Sampler design (e.g., air monitors) will be reviewed at least biannually to determine equipment efficiency and compliance with current EPA and industry [e.g., ANSI and American Society for Testing and Materials (ASTM)] standards. 


\subsection{COMMUNICATION}

The Operations and Engineering Contractor and the Research and Development Contractor will compare and communicate results of their respective monitoring programs at least quarterly and as soon as possible under upset conditions.

\subsection{REPORTS}

Results of the near-field operational environmental monitoring program are published in the document series Westinghouse Hanford Company Environmental Surveillance Annual Report (WHC 1988e). Results of routine radiological surveys are published in the document series WHC-SP-0665, Quarterly Environmental Radiological Survey Summary (Huckfeldt 1992). The radionuclide values in these reports are expressed in curies, or portions thereof, for each radionuclide per unit weight of sample (e.g., picocuries per gram) or in field instrument values (e.g., counts per minute) rather than EDE, which is calculated as the summation of the products of the dose equivalent received by specified tissues of the body and a tissue-specific weighing factor. 
WHC-EP-0466-1

This page intentionally left blank. 


\subsection{QUALITY ASSURANCE}

Quality Assurance is an essential portion of the FEMP effort. WHC-E.P-0536, Quality Assurance Program Plan for Radionuclide Airborne Emissions Monitoring (WHC 1991h), was prepared to meet the QA performance requirements of 40 CFR, part 61, Appendix B, Method 114.

\subsection{PURPOSE}

This $Q A P I$ an describes the quality assurance requirements associated with implementing FEMPs. The plan identifies the FEMP activities and assigns the appropriate quality assurance requirements defined by the Westinghouse Hanford Quality Assurance Manual, WHC-CM-4-2 (WHC 1989f). This QA Plan shall be consistent with the requirements in DOE Order 5700.6C, "Quality Assurance" (DOE 1991b). In addition, QA requirements in 40 CFR 60, Appendix $A$, "Reference Methodologies" (EPA 1986b) shal1 be considered when performing monitoring calculations and establishing monitoring systems.

\subsection{OBJECTIVE}

The objective of this $\mathrm{plan}$ is to provide a documented QA plan describing QA requirements for the 242-A Evaporator Facility.

\subsection{REQUIREMENTS}

A quality assurance project plan (QAPjP) (WHC 1992f) has been developed to implement the overal1 QA program requirements defined by WHC-CM-4-2 (WHC 1989f). The QAPJP applies specifically to the field activities, laboratory analyses, and continuous monitoring performed for al1 FEMPs conducted by Westinghouse Hanford. Plans and procedures referenced in the QAPJP are available for regulatory review on request by the direction of the Westinghouse Hanford Environmenta1 Assurance Manager. A QAPP for radioactive airborne emissions was prepared (WHC 1991h) to address the QA elements of 40 CFR 61 and was submitted to the EPA.

\subsection{FACILITY-SPECIFIC REQUIREMENTS}

The QAPJP includes a list of analytes of interest and analytical methods for liquid effluent monitoring at the Hanford Site. The analytes of interest applicable to the 242-A Evaporator have been identified in the QAPJP. The airborne effluent analytes of interest and analytical methods also are included in the QAPJP. Procedures are performed by health physics personnel and are referenced in the health physics procedures manual (WHC 1992g). 
WHC-EP-0466-1

This page intentionally left blank. 


\subsection{INTERNAL AND EXTERNAL PLAN REVIEW}

DOE Order 5400.1, "General Environmental Protection Program," Chapter IV.4 (DOE 1990b) requires the FEMP to be reviewed annually and updated every $3 \mathrm{yr}$. The FEMP should be reviewed and updated as necessary after each major change or modification in the facility processes, facility structure, ventilation and liquid collection systems, monitoring equipment, waste treatment, or a significant change to the safety analysis reports.*

Facility operators will have to assess that no changes have occurred in operations that would require new testing semiannually. Although the renort is based on the calendar year, the emission limits apply to any period of 12 consecutive months. Westinghouse Hanford Environmental Protection prepares an annual effluent discharges report for each area on the Hanford Site that covers both airborne and liquid release pathways (WHC 1990a). In addition, a report on the air emissions and compliance to the Clean Air Act of 1977 (NESHAP) is prepared by Westinghouse Hanford Environmental Protection for the $\mathrm{RL}$ for submittal to EPA as well as DOE Headquarters (DOE-RL 1992).

Facility management will obtain approval from the Effluent and Emissions Monitoring group for all changes to the FEMPS, including those generated in the annual review and update. In addition, $Q A$ and Regulatory Analysis shall review the FEMP.

* Facility management is responsible for ensuring that the reviews and updates are performed. Records retention shall be in accordance with the QAPP. 
WHC-EP-0466-1

This page intentionally left blank.

9

1 


\subsection{EFFLUENT MONITORING/SAMPLING ASSESSMENT}

The purpose of this chapter is threefold and accomplishes the following:

1. This chapter assesses compliance of the facility effluent monitoring/sampling systems with the regulatory requirements, the referenced standards, and DOE orders.

2. Secondly, this chapter addresses any exemptions for which application has been made.

3. Finally, this chapter addresses system upgrades required for compliance.

\subsection{COMPLIANCE ASSESSMENT}

Regulatory compliance assessments are conducted within this section for the gaseous and liquid streams at the 242-A Evaporator facility. Point-bypoint comparisons with applicable regulations are accomplished for each of the streams identified in this FEMP.

\subsubsection{Regulations Governing Airborne Emissions}

Airborne emissions of radioactive materials from DOE-controlled facilities at the Hanford Site are subject to 40 CFR Part 61, National Emissions Standards for Hazardous Air Pollutants (NESHAPs) (EPA 1991b) as stated in DOE Order 5400.5, Radiation Protection of the Public and the Environment (DOE 1990b), and DOE Order 5400.1, Chapter IV, Environmental Monitoring Requirements (DOE 1990a). The list of hazardous air pollutants regulated under the NESHAPs is provided in Subpart A, General Provisions. The specific emissions standards and monitoring requirements for radionuclides are contained in Subpart H, National Emission Standards for Emissions of Radionuclides Other Than Radon From Department of Energy Facilities. Subpart $H$ covers all DOE operations that emit radionuclides other than radon to the air, except for facilities subject to 40 CFR Part 191, Subpart B (EPA 1991d), and 40 CFR Part 192 (EPA 1991e).

Title 40 CFR Part 61 (EPA 1991b), Subpart H, presents detailed requirements for emissions monitoring and test procedures (61.93), compliance and reporting (61.94), record keeping requirements (61.95), and exemptions from the reporting and testing requirements of 40 CFR Part 61.10 (61.97). Radionuclide emission rates from stacks and vents must be measured at ali release points that have the potential to discharge radionuclides into the air in quantities that could cause an EDE in excess of $1 \%$ of the standard of $10 \mathrm{mrem} / \mathrm{yr}$ specified in 40 CFR 61.92 . This standard establishes the continuous monitoring and measurement requirement at $0.1 \mathrm{mrem} / \mathrm{yr}$.

To determine compliance with the radionuclide emission standard specified in 40 CFR 61.92 (EPA 1991b), radionuclide emissions must be determined and the

*A mrem is $1 / 1000$ of a rem. 
potential EDE values to members of the public from particular release points must be calculated. This was accomplished in Chapter 4 of this FEMP for the 296-A-22 stack (Section 4.2.1.1, Table 4-2) and for the 296-A-21 stack

(Section 4.2.1.2, Table 4-5). If the EDE at a particular release point is in excess of $1 \%$ of the standard $(>0.1 \mathrm{mrem} / \mathrm{yr})$, radionuclide emission

measurements must be accomplished as specified in 40 CFR 61.93 (b) (4)(i).

Table 4-2 shows that the potential offsite EDE contribution from the

$296-\mathrm{A}-22$ stack $(0.13 \mathrm{mrem} / \mathrm{yr})$ is in excess of the specified $0.1 \mathrm{mrem} / \mathrm{yr}$. In addition, Table 4-5 shows that the potential offsite EDE contribution from the 296-A-21 stack (0.26 mrem/yr) is in excess of the specified $0.1 \mathrm{mrem} / \mathrm{yr}$.

Therefore, radionuclide emission measurements must be accomplished on the 242-A Evaporator vessel vent (296-A-22) and building vent (296-A-21) stacks in conformance with the requirements of 40 CFR 61.93 (b).

The 40 CFR 61.93 (b)(4)(i) also specifies that, relative to release points potentially providing an offsite EDE in excess of $1 \%$ of the standard, all radionuclides that could contribute greater than $10 \%$ of the potential EDE for each specific release point shall be measured. The determination of these radionuclides was also accomplished in Chapter 4 (Tables 4-2 \& 4-5). For the vessel vent stack, the only $>10 \%$ contributor is ${ }^{100} \mathrm{Ru}$. For the building vent stack, the $>10 \%$ contributors are ${ }^{241} \mathrm{Am}$ and $239,240 \mathrm{Pu}$.

40 CFR 61.93 (b) (2) (iii) (EPA 1991b) specifies that radionuclides shall be collected and measured using procedures based on the principles of measurements described in 40 CFR 61, Appendix B, Method 114. These methods are part of the laboratory procedures and are addressed in Chapter 9 of this FEMP, in the FEMP associated with the laboratory (WHC 1991i), and in section 14.1.2.7 of this chapter.

The requirement specified by 40 CFR 61.93 (b)(2)(iv) that a QA program shall be conducted that meets the performance requirements described in 40 CFR 61, Appendix B, Method 114, is addressed in Chapter 12.0 and in Section 14.1.2.7 of this chapter.

\subsubsection{Gaseous Streams Point-By-Point Compliance Assessment}

The following is a point-by-point comparison of the 242-A Evaporator with applicable parts of 40 CFR 61, Subpart $H$, and other referenced guidelines for stacks 296-A-22 and 296-A-21. Comparison information concerning Hanford stacks in general was taken from WHC-EP-0542, 242-A Evaporator Comparison With 40 CFR 61, Subpart $H$, and Other Referenced Guidelines For Stack 296-A-22 (WHC 1991g).

\subsubsection{40 CFR 61, SUBPART H: Comparison to 242-A Evaporator Stacks}

61,92 Standard. Emissions of radionuclides to the ambient air from Department of Energy facilities shall not exceed those amounts that would cause any member of the public to receive in any year an effective dose equivalent of $10 \mathrm{mrem} / \mathrm{yr}$.

Dose calculations for atmospheric radionuclide releases from the Hanford Site for calendar years (CY) 1990 and 1991 were performed by Pacific Northwest Laboratory (PNL) using the approved U.S. Environmental 
Protection Agency (EPA) CAP-88 computer model. Emissions from discharge points in the Hanford Site 100, 200,300, 400, and 600 areas were calculated based on results of analyses of periodic sampling conducted at the discharge points. These calculated emissiors were provided for inclusion in the CAP-88 model by area and by individual facility for those facilities having the potential to contribute more than $10 \%$ of the Hanford Site total or to result in an impact of greater than $0.1 \mathrm{mrem}$ per year to the maximally exposed individual. Also included in the assessment of offsite dose modeling are the measured radioactive emissions from all Westinghouse Hanford stacks that have routine monitoring performed. Record sampling systems have been installed on all stacks and vents that use exhaust fans to discharge air that may potentially carry airborne radioactivity. Estimation of activity from ingrowth of long-lived radioactive progeny is not included in the CAP-88 mode1; therefore, the Hanford Site GENII code (Napier et a1. 1988) was used to supplement the CAP- 88 dose calculations. When the dose to the maximally exposed individual located in the Ringold area was calculated, the effective dose equivalent from combined Hanford Site radioactive airborne emissions was shown to be $9.3 \mathrm{E}-03 \mathrm{mrem}$ in 1990 and $6.8 \mathrm{E}-03$ in 1991. These values were reported in the annual air emissions reports prepared for the Hanford Site (DOE-RL 1991, DOE-RL 1992). Not inciuded in these values was data from 296-A-22 stack, as it was not operating during those time periods.

61.93 Emission monitoring and test procedures

(a) To determine compliance, radionuclide emissions shall be determined and effective jose equivalent values calculated using EPA approved sampling procedures, computer models CAP-88 or AIRDOS-PC, or other procedures for which EPA has granted prior approval.

Dose calculations for atmospheric radionuclide releases from the Hanford Site for calendar years (CY) 1990 and 1991 were performed by Pacific Northwest Laboratory (PNL) using the approved U.S. Environmental Protection Agency (EPA) CAP-88 computer model. Emissions from discharge points in the Hanford Site $100,200,300,400$, and 600 areas were calculated based on results of analyses of periodic sampling conducted at the discharge points. These calculated emissions were provided for inclusion in the CAP-88 model by area and by individual facility for those facilities having the potential to contribute more than $10 \%$ of the Hanford Site total or to result in an impact of greater than 0.1 mrem per year to the maximally exposed individual. Also included in the assessment of offsite dose modeling are the measured radioactive emissions from all Westinghouse Hanford stacks that have routine monitoring performed. Record sampling systems have been installed on all stacks and vents that use exhaust fans to discharge air that may potentially carry airborne radioactivity. Estimation of activity from ingrowth of long-lived radioactive progeny is not included in the CAP-88 model; therefore, the Hanford Site GENII code (Napier et al. 1988) was used to supplement the CAP-88 dose calculations. When the dose to the maximally exposed individual located in the Ringold area was calculated, the effective dose equivalent from combined Hanford Site radioactive airborne emissions was shown to be $9.3 \mathrm{E}-03 \mathrm{mrem}$ in 1990 and 6.8E-03 in 1991. These values were reported in the annual air emissions 
reports prepared for the Hanford Site (DOE-RL 1991, DOE-RL 1992). Not included in these values was data from 296-A-22 stack, as it was not operating during those time periods.

(b) Stacks shall be measured in accordance with the following requirements or other procedures for which EPA has granted prior approval:

(1) Effluent flow rate measurements shall be made using the following:

(i) Reference Method 2 of Appendix A to part 60 for large stacks.

296-A-22: The defining criteria for large stacks is stacks that have a cross-sectional diameter greater than $0.30 \mathrm{~m}$ (12 in) or $0.071 \mathrm{~m}^{2}\left(113 \mathrm{in}^{2}\right)$ in cross-sectional area. This circular stack has an $0.20-m-(8-i n-)$ diameter cross-section and, therefore the requirements of Reference Method 2C, Determination of Stack Gas Velocity and Volumetric Flowrate in Small Stacks or Ducts (Standard Pitot Tube) apply. The apiaratus, procedure, calibration, calculations, and bibliography are the same as in Method 2, except as noted in Method 2C. A determination of compliance is provided in the point-by-point compliance section "METHOD 2C" (Section 14.1.2.3 of this chapter).

296-A-21: This circular stack has a diameter of $1.06 \mathrm{~m}$ (42-in) and therefore meets the defining criteria for a large stack. Reference Method 2 is applicable. A determination of compliance is provided in the point-by-point compliance section "METHOD 2" (Section 14.1.2.2 of this chapter).

(iii) Frequency of measurements shall depend upon the variability of the effluent flow rate. For variable flow rates, cont inuous or frequent flow rate measurements shall be made. for relatively constant flow rates only periodic measurements are necessary.

296-A-22: A flowrate with a variability of less than $\pm 20 \%$ has been defined at the Hanford Site as being relatively constant. This criterion is specified in SD-WM-CR-016, Design Criteria: FY 1985 200 Area Stack Sampler-Monitor System Upgrade. From flow rate data collected between September 1987 and January 1991, it can be shown that the flowrate for this stack varies by $+15 \%$ and $-17 \%$. The flowrate measurement is, therefore, taken periodically (quarterly).

296-A-21: A flowrate with a variability of less than $\pm 20 \%$ has been defined at the Hanford Site as being relatively constant. This criterion is specified in SD-WM-CR-016, Design Criteria: FY 1985 200 Area Stack Sampler-Monitor System Upgrade (RHO, 1984). From flow rate data collected between September 1987 and August 1991, it can be shown that the flowrate for this stack varies by $+17 \%$ and $-25 \%$. Therefore, by Hanford Site criteria, the flowrate is variable. The flowrate measurement is taken periodically (quarterly), but should be taken frequently or continuously.

NOTE: Constant flow is defined in 40 CFR, Part 60, Appendix A, Method 1A, Section 2.1.2 as "within 10 percent". By this criterion, frequent or continuous measurement of stack flow should be made on both Stacks 296-A-21 and 296-A-22. 
(2) Radionuclides shall be directly monitored or extracted, collected and measured using the following:

(i) Reference Method 1 of Appendix A part 60 shall be used to select monitoring or sempling sites.

296-A-22: Method 1 applies to large stacks. The defining criterion for large stacks is stacks that have a cross-sectional diameter greater than $0.30 \mathrm{~m}$ (12 in) or $0.071 \mathrm{~m}^{2}\left(113 \mathrm{in}^{2}\right)$ in crosssectional area. This circular stack has an $0.20-m-(8-i n-)$ diameter cross-section and, therefore the requirements of Reference Method 1A, Sample and Velocity Transverses For Stationary Sources With Small Stacks or Dict:, apply. The applicability, principle, and procedure are the same as in Method 1, except as noted in Method 1A. A determination of compliance is provided in the pointby-point compliance Section 14.1.2.5, "METHOD 1A".

296-A-21: This circular stack has a diameter of $1.06 \mathrm{~m}$ (42 in) and therefore meets the defining criteria for a large stack. Reference Method 1 is appiicable. A determination of compliance is provided in the point-by-point compliance Section 14.1.2.4, "METHOD 1".

(ii) The efflucit stream shall be directly monitored continuously with an in-line detector or representative samples of the effluent stream shall be withdrawn cont inuously from the sampling site following the guidance of ANSI N13.1-1969 (including Appendix A of ANSI N13.1).

Both stacks possess effluent monitoring/sampling systems that continuously withdraw samples from the sampling sites. The degree to which the guidance provided in ANSI N13.1-1969 is followed, and, hence, the representativeness of the samples is analyzed in the point-by-point compliance Section 14.1.2.6, "ANSI N13.1-1969".

(3) When impractical to measure as in $(b)(1)$ or to monitor or sample as in (b)(2), see this section for further requirements.

(4) (i) Radionuclide emission measurements shall be made at all release points which have a potential to discharge radionuclides into the air in quantities which could cause an effective dose equivalent (EDE) in excess of $1 \%$ of the standard. All radionuclides which could contribute greater than $10 \%$ of the potential EDE for a release point shall be measured. For other release points with potential to release radionuclides, periodic confirmatory measurements shall be made.

296-A-22: Table 4-2 lists specific radionuclide contributions to the potential EDE for the 242-A Evaporator Vessel Vent stack. The only radionuclide that exceeds $1 \%(0.1 \mathrm{mrem})$ of the standard is ${ }^{106} \mathrm{Ru}(0.13 \mathrm{mrem}) .{ }^{106} \mathrm{Ru}$ is collected on silver zeolite cartridges, which are gathered weekly for laboratory analysis. Based on the evaluation in Chapter 4 of this FEMP, the only radionuclide that could contribute greater than $10 \%$ of the potential EDE for the Vessel Vent stack is ${ }^{125} \mathrm{Sb} .{ }^{125} \mathrm{Sb}$ is collected on filter media that are exchanged weekly. Laboratory analys is is conducted to specifically measure ${ }^{125} \mathrm{Sb}$. Other radionuclides that are measured specifically in this stack are ${ }^{137} \mathrm{Cs},{ }^{129} \mathrm{I},{ }^{113} \mathrm{Sn},{ }^{89} \mathrm{Sr}$, and ${ }^{90} \mathrm{Sr}$.

296-A-21: Table 4-5 lists specific radionuclide contributions to the potential EDE for the 242-A Evaporator Building Vent stack. The only radionuclide that exceeds $1 \%(0.1 \mathrm{mrem})$ of the standard is 
${ }^{241} \mathrm{Am}(0.25 \mathrm{mrem})$. Based on the evaluation in Chapter 4 of this FEMP, ${ }^{249} \mathrm{Am}$ is al so the only radionuclide that could contribute greater than $10 \%$ of the potential EDE for the Building Vent stack. ${ }^{241} \mathrm{Am}$ is collected on filter media that are exchanged weekly. Laboratory analysis is conducted to specifically measure ${ }^{24} \mathrm{Am}$. other radionuclides that are measured specifically in this stack are ${ }^{239} \mathrm{Pu}$ and ${ }^{240} \mathrm{Pu}$.

(ii) In evaluating the potential of a release point to discharge radionuclides into the air for the purposes of this section, the estimated rad release rates shall be based on the discharge of the effluent stream that would result if all pollution control equipment did not exist, but the facility operations were otherwise normal.

Tables 4-2 and 4-5 tabulate the potential resultant offsite dose, as well as the contributing percentage, for specific radionuclides emitted from the 296-A-22 and 296-A-21 stacks, respectively. These values were calculated with the pollution control equipment removed, but the facility operations otherwise normal. The pollution control is identified as the high-efficiency particulate air (HEPA) fiiters. To account for the loss of HEPA filtration, a factor of 3000 was used to increase emission data. The CAP-88 conversion factors were used to calculate offsite doses. Note that iodine is gaseous and, therefore, would not be contained by the HEPA filters. In other words, the emissions would be the same for iodine with or without the HEPA filters.

\subsection{Comol iance and reporting.}

(a) Compliance with this standard shall be determined by calculating the highest EDE to any member of the public at any offsite point where there is a residence, school, business, or office. Each facility shall submit an annual report to both EPA HQ and Regional by June 30 which includes monitoring results and dose calculations required by 61.43 (a) for the previous calendar year.

The Ringold location was chosen several years ago as the area where the offsite dose from all air pathways would be the highest for the maximally exposed individual (MEI) for the Hanford Site. The selection of Ringold was made because nearly all of the dose from air releases in recent years has been contributed by radionuclides from the PlutoniumUranium Extraction (PUREX) Plant stack. The Ringold area is the closest farming area to the PUREX Plant, and it realistically matches the assumption that the MEI diet consists of $100 \%$ home-grown food. The Ringold area has historically been capable of producing all of the items in the MEI diet with the possible exception of cereal grain. The Ringold area lies very nearly in the path of the prevailing winds from the 200 East area. The atmospheric dispersion factor $(X / Q)$ at Ringold is historically within $10 \%$ to $20 \%$ of the maximum offsite $X / Q$ value associated with 200 Areas releases. The maximum value usually occurs in an adjacent sector where there is no farming.

The U.S. Department of Energy Field Office, Richland (RL) provided the annual report for CY 1991 (DOE-RL 1992) to U.S. Department of Energy Headquarters, Environmental Protection Agency Region $X$ personnel, and Washington Department of Health personnel in compliance with the regulatory deadline. 
(b) The annual report shall also include: (Future annual reports will also address the following requirements.)

(1) Name and location of facility.

RL-92-30, Pages 1-6 through 1-29. Hanford Site summary is discussed on Pages 1-1 through 1-5.

(2) List of radioactive materials used at the facility.

RL-92-30, Table 2-1 on pages 2-2 through 2-10.

(3) Description of handling and processing of rad materials at the facility.

RL-92-30, Pages 1-6 through 1-29.

(4) List of the stacks and vents or other points where radioactive materials are released to the atmosphere.

RL-92-30, Pages 1-6 through 1-29.

(5) A description of the effluent controls that are used on each stack, vent, or other release point and an estimate of the efficiency of each control device.

RL-92-30, Table 2-1 on Pages 2-2 through 2-10.

(6) Distances from the points of release to the nearest residence, school, business or office and the nearest farms producing vegetables, milk and meat.

RL-92-30, Tables 3-2, 3-3, in Section 3. These tables show the CAP-88 Dose Estimates for the Offsite Individual at Ringold Exposed to Radionuclide Emissions from Hanford Site During 1990. Please also refer to explanatory remarks for 61.94 above.

(7) The values used for all other input parameters for the computer models (meteorological data) and the source of these data.

Input parameters are shown in Table 2-1, Pages 2-2 through 2-10 of $\mathrm{RL}-92-30$. Annual average dispersion factors around $100,200,300$, and 400 Areas during 1991 are given in Tables 3-5 through 3-9 of $\mathrm{RL}-92-30$. These tables use site-specific measurements of the occurrence frequencies for wind speed, wind direction, and atmospheric stability. The products of the dispersion models are annual average dispersion factors $\left(X / Q^{\prime}\right.$, in units of $\mathrm{Ci} / \mathrm{m}^{3} \mathrm{per} \mathrm{Ci} / \mathrm{s}$ or $\mathrm{s} / \mathrm{m}^{3}$ ) that, when combined with annual average release rates, will predict average radionuclide air concentrations for the year.

(8) A brief description of all construction and modifications which were completed in the calendar year for which the report is prepared, but for which the requirement to apply for approval to construct or modify was waived under 61.96 .

RL-92-30, Section 3.5.1, discusses the "Purgewater Storage and Treatment Facility Modification", for which approval to construct or modify was waived under 40 CFR Part 61.96 . 
(9) Each report shall be signed and dated by a corporate officer or public official in charge of the facility and containing a declaration of belief of accuracy and truth of the report.

RL-92-30, page 3-13, signed by John D. Wagoner, Manager, Field Office-Richland (U.S. Department of Energy). following the noncompliance annual report. Monthly reports shall also include:

The Hanford Site is in compliance with 61.96; hence, this section is not applicable.

This information is not classified; hence, this section is not applicable.

\subsection{Recordkeeping requirements.}

All facilities must maintain records documenting the source of input parameters including the results of all measurements, calculations, analytical methods, and procedure for determining EDE. Sufficient information to allow an independent auditor to verify the accuracy should be kept. The records must be kept at the site for at least five years and must be made available upon request to an authorized representative.

The records mentioned above are maintained at the Hanford Site for the required period as a minimum.

61.96 Apolications to construct or modify.

This requirement is not applicable to the 242-A evaporator.

61.97 Exemption from the reporting and testing requirements of 40 CFR 61.10 .

All facilities designated under subpart $H$ are exempt from the reporting requirements of 40 CFR 61.10.

\subsubsection{40 CFR 60, APPENDIX A, REFERENCE METHOD 2: Comparison to Stack 296-A-21}

1.0 Principle and Appl icability

1.1 Principle. The average gas velocity in a stack is determined from the gas density and from measurement of the average velocity head with a Type $S$ (Stausscheibe or reverse type) pitot tube.

A standard pitot tube is used as provided for in Section 2.1 of this Reference Method 2.

1.2 Applicability. This method is applicable for measurement of the average velocity of a gas stream and for quantifying gas flow.

This procedure is not applicable at measurement sites which fail to meet the criteria of Method 1. Section 2.1. Also, the method cannot be used for direct measurement in cyclonic or swirling gas streams; Section 2.4 of Method 1 shows how to determine cyclonic or swirling flow conditions. When unacceptable conditions exist, al ternative procedures, subject to the approval of the Administrator, U.S. Environmental Protection Agency, must be employed to make accurate flow rate determinations; examples of such alternative procedures are: (1) to install straightening vanes; (2) to calculate the total volumetric flow rate stoichiometrically; or (3) to move to another measurement site at which the flow is acceptable. 
The compliance assessment of the current velocity measurement site for the 296-A-21 stack is addressed in Section 14.1.2.4 of this chapter.

\title{
Apoaratus
}

Specifications for the apparatus are given below. Any other apparatus that has been demonstrated (subject to approval of the Administrator) to be cupable of meeting the specifications will be considered acceptable.

2.1 Type $S$ pitot Tube. The Type $S$ pitot tube (Figure 2-1) shall be made of metal tubing (e.g., stainless steel). It is recommended that the external tubing diameter (dimension $D t$ Figure $2-2 b)$ be between 0.48 and 0.95 centimeter $(3 / 16$ and $3 / 8$ inch). There shall be an equal distance from the base of each leg of the pitot tube to its face-opening plane (dimensions PA and PB Figure 2-2b); it is recommended that this distance be between 1.05 and 1.50 times the external tubing diameter. The face openings of the pitot tube shall, preferably, be aligned as shown in Figure 2-2; however, slight misalignments of the openings are permissible (see Figure 2-3).

The Type S pitot tube shall have a known coefficient, determined as outlined in Section 4 . An identification number shs.ll be assigned to the pitot tube; this number shall be permanentiy marked or engraved on ine body of the tube.

\begin{abstract}
A standard pitot tube may be used instead of a Type $S$, provided that it meets the specifications of Sections 2.7 and 4.2: note, however, that the static and impact pressure holes of standard pitot tubes are susceptible to plugging in particulate-laden gas streams. Therefore, whenever a standard pitot tube is used to perform a traverse adequate proof must be furnished that the openings of the pitot tube have not plugged up during the traverse period; this can be done by taking a velocity head $\Delta P$ reading at the final traverse point, cleaning out the impact and static holes of the standard pitot tube by "back-purging" with pressurized $a i r$, and then taking another $\triangle P$ reading. If the $\triangle P$ readings made before and after the air purge are the same $( \pm 5$ percent), the traverse is acceptable. Otherwise, reject the run. Note that if $\Delta P$ at the final traverse point is unsuitably low, another point may be selected. If "back-purging" at regular intervals is part of the procedure, then comparative $\Delta P$ readings shall be taken, as above, for the last two back purges at which suitably high $\Delta P$ readings are observed.
\end{abstract}

An ASME design stainless steel standard pitot tube is used, which meets AMCA and ASHRAE specifications for maximum accuracy over a wide variety of flow conditions. The standard pitot tubes used for velocity traverses are Dwyer. Series 160 or equivalent and meet the criteria of Section 2.7. The pitot tubes used do not require calibration and they use a manufacturer's recommended coefficient value of "1". The pitot tubes are used in conjunction with a digital micromanometer. The internal program of the micromanometer uses unity as the baseline coefficient.

2.2 Differential Pressure Gauge. An inclined manometer or equivalent device is used. Most sampling trains are equipped with a 10-in. (water column) inclined-vertical manometer, having $0.01-i n$. $\mathrm{H}_{2} \mathrm{O}$ divisions on the $\mathrm{O}$-to 1 -in. inclined scale, and $0.1-\mathrm{in}$. $\mathrm{H}_{2} \mathrm{O}$ divisions on the 1-to 10-in? vertical scale. This type of manometer (or other gauge of equivalent sensitivity) is satisfactory for the measurement of $\triangle P$ values as low as $1.3 \mathrm{~mm}(0.05 \mathrm{in.}) \mathrm{H}_{2} \mathrm{O}$. However, a differential pressure gauge of greater sensitivity shall be used (subject to the approval of the Administrator), if any of the following is found to be true: (1) the arithmetic average of all $\Delta P$ readings at the traverse points in the stack is less than $1.3 \mathrm{~mm}(0.05 \mathrm{in}$. $) \mathrm{H}_{2} 0$; (2) for traverses of 12 or more points, more than 10 percent of the individual $\triangle P$ readikgs are below $1.3 \mathrm{~mm}\left(0.05 \mathrm{in.)} \mathrm{H}_{2} \mathrm{O}\right.$; (3) for traverses of fewer than 12 points, more than one $\Delta P$ reading is below $1.3 \mathrm{~mm}\left(0.05 \mathrm{in.}\right.$ ) $\mathrm{H}_{2} 0$. Citation 18 in section 6 describes commercially available instrumentation for the measurement of low-range gas velocities.

The device used is a digital micromanometer (Air-Neotronics Limited, Model MP20 SR) that has the capability of calculating and displaying corrected velocity readings, directly from pitot or total head probes, after density correction instructions are input into the built-in microcomputer. Using the Density Program, velocities can be displayed 
in any of 8 ranges spanning 300 to 20,000 feet per minute, resolving to $10 \mathrm{ft} / \mathrm{min}$. The instrument displays in any of 7 pressure scales, as follows:

\begin{tabular}{|c|c|c|c|}
\hline 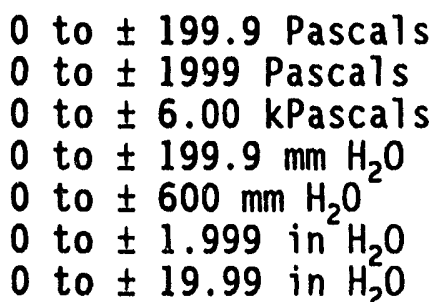 & $\begin{array}{c}\text { resolving } t \\
" \\
" \\
" \\
" \\
" \\
"\end{array}$ & $\begin{array}{l}\text { " } \\
\text { " } \\
" 1 \\
\text { " }\end{array}$ & $\begin{array}{l}0.1 \mathrm{~Pa} \\
1 \mathrm{~Pa} \\
0.01 \mathrm{kPa} \\
0.1 \mathrm{~mm} \mathrm{H} \mathrm{H}_{2} \mathrm{O} \\
1 \mathrm{~mm} \mathrm{H}_{2} \mathrm{O} \\
0.001 \mathrm{in} \mathrm{H}_{2} \mathrm{C} \\
0.01 \text { in } \mathrm{H}_{2} \mathrm{O}\end{array}$ \\
\hline
\end{tabular}

The instrument has negligible zero drift due to a built-in auto zeroing sequence that is initiated every 2 to 3 minutes. Span drift is typically $0.05 \%$ of range per ${ }^{\circ} \mathrm{C}$. The instrument is vibration and shock resistant. Currently, only velocity pressure readings are taken with the instrument.

As an alternative to criteria (1) through (3) above, the following calculation may be performed to determine the necessity of using a more sensitive differential pressure gauge:

(see equation 40 CFR Pt. 60 App. A, Meth. 2, page 645)

Not applicable.

If $T$ is greater than 1.05 , the velocity head data are unacceptable and a more sensitive differential pressure gauge must be used.

NOTE: If differential pressure gauges other than inclined manometers are used

(e.g. magnehelic gauges) their calibration must be checked after each test series. To check the calibration of a differential pressure gauge, compare $\Delta$ P readings of the gauge with those of a gauge-oil manometer at a minimum of three points, approximately representing the range of $\Delta P$ values in the stack. If, at each point, the values of $\Delta P$ as read by the differential pressure gauge and gauge-oil manometer agree to within 5 percent, the differential pressure gauge shall be considered to be in proper calibration. otherwise, the test series shall either be voided, or procedures to adjust the measured $\Delta P$ values and final results shall be used subject to the approval of the Administrator.

Digital micromanometer is self-calibrating.

2.3 Temperature Gauge. A thermocouple, liquid-filled bulb thermometer, bimetallic thermometer, mercury-in-glass thermometer, or other gauge, capable of measuring temperature to within 1.5 percent of the minimum absolute stack temperature shall be used. The temperature gauge shall be attached to the pitot tube such that the sensor tip does not touch any metal; the gauge shall be in an interference-free arrangement with respect to the pitot tube face openings (see Figure 2-1 and aiso Figure 2-7 in Section 4). Alternate positions may be used if the pitot tube-temperature gauge system is calibrated according to the procedure of Section 4. Provided that a difference of not more than 1 percent in the average velocity measurement is introduced, the temperature gauge need not be attached to the pitot tube; this al ternative is subject to the Approval of the Adninistrator.

A temperature gauge is not used in current practice.

2.4 Pressure Probe and Gauge. A piezometer tube and mercury- or water-filled U-tube manometer capable of measuring stack pressure to within $2.5 \mathrm{~mm}(0.1 \mathrm{in.}) \mathrm{Hg}$ is used. The static tap of a standard type pitot tube or one leg of a Type $S$ pitot tube with the face opening planes positioned parallet to the gas flow may also be used as the pressure probe.

Static pressure is not measured in current practice. 
2.5 Barometer. A mercury, aneroid, or other barometer capable of measuring atmospheric pressure to within $2.5 \mathrm{~mm} \mathrm{Hg}(0.1 \mathrm{in}$. $\mathrm{Hg}$ ) may be used. In many cases, the barometric reading may be obtained from a nearby National Weather Service station, in which case the station value (which is the absolute barometric pressure) shall be requested and an adjustment for elevation differences between the weather station and the sampling point shall be applied at a rate of minus $2.5 \mathrm{~mm}$ ( $0.1 \mathrm{in.)} \mathrm{Hg}$ per 30-meter (100 foot) elevation increase or vice-versa for elevation decrease.

\section{Barometric pressure is not measured in current practice.}

2.6 Gas Density Deternınation Equipment. Method 3 equipment, if needed (see Section 3.6 ), to determine the stack gas dry molecular weight, and Reference Method 4 or Method 5 equipment for moisture content determination; other methods may be used subject to approval of the Administrator.

\section{Gas density is not determined in current practice.}

2.7 Calibration Pitot Tube. When calibration of the Type $S$ pitot tube is necessary (see Section 4), a standard pitot tube is used as a reference. The standard pitot tibe shall, preferably, have a known coefficient, obtained either (1) directly from the National Bureau of Standards, Route 270, Quince Orchard Road, Gaithersburg, Maryland, or (2) by calibration against another standard pitot tube with an NBS-traceable coefficient. Alternatively, a standard pitot tube designed according to the criteria given in 2.7 .1 through 2.7 .5 below and illustrated in Figure 2-4 (see also Citations 7,8 , and 17 in Section 6) may be used. Pitot tubes designed according to these specifications will have baseline coefficients of about 0.99 \pm 0.01 .

Not necessary. Type S pitot tube is not used.

2.7.1 Hemispherical (shown in Figure 2-4), ellipsoidal, or conical tip.

2.7.2 A minimum of six diameters straight run (based upon $D$, the external diameter of the tube) between the tip and the static pressure holes.

2.7.3 A minimum of eight diameters straight run between the static pressure holes and the centerline of the external tube, following the 90 degree bend.

2.7.4 Static pressure holes of equal size (approximately 0.10 ), equally spaced in a piezometer ring configuration.

2.7.5 Ninety degree bend, with curved or mitered junction.

2.8 Differential Pressure Gauge for Type S Pitot Tube Calibration. An inclined manometer or equivalent is used. If the single-velocity calibration technique is employed (see Section 4.1.2.3), the calibration differential pressure gauge shall be readable to the nearest $0.13 \mathrm{~mm} \mathrm{H} O\left(0.005 \mathrm{in}\right.$. $\left.\mathrm{H}_{2} \mathrm{O}\right)$. For multivelocity calibration, the gauge shall be readable to the nearest $0.13 \mathrm{~mm} \mathrm{H}_{2} O$ ? $0.005 \mathrm{in}$. $\left.\mathrm{H}_{2} \mathrm{O}\right)$ for $\triangle \mathrm{P}$ values between 1.3 and $25 \mathrm{~mm} \mathrm{H}_{2} \mathrm{O}(0.05$ and $1.0 \mathrm{in}$. $\left.\mathrm{H}_{2} \mathrm{O}\right)$, and to the nearest $1.3^{2} \mathrm{~mm} \mathrm{H}_{2} \mathrm{O}\left(0.05\right.$ in. $\left.\mathrm{H}_{2} \mathrm{O}\right)$ for $\triangle \mathrm{P}$ values above $25 \mathrm{~mm} \mathrm{H} \mathrm{H}_{2} \mathrm{O}$ $\left(1.0\right.$ in. $\left.H_{2} 0\right)$. A special, more sensitive gauge will be required to read aP values below $1.3 \mathrm{~mm} \mathrm{H}_{2} \mathrm{O}^{2}\left[0.05\right.$ in. $\left.\mathrm{H}_{2} \mathrm{O}\right]$ ' (see Citation 18 in Section 6).

Not necessary. Type S pitot tube is not used.

3.0 Procedure

3.1 Set up the apparatus as shown in Figure 2-1. Capillary tubing or surge tanks installed between the manometer and pitot tube may be used to dampen $\Delta p$ fluctuations. It is recommended, but not required that a pretest leak-check be conducted as follows: (1) blow through the pitot impact opening until at least $7.6 \mathrm{~cm}(3 \mathrm{in}.) \mathrm{H}_{2} \mathrm{O}$ velocity pressure registers on the manometer; then, close off the impact opening. The pressure shall remain stable for at least 15 seconds; (2) do the same for the static pressure side, except using suction to obtain the minimum of $7.6 \mathrm{~cm}\left(3 \mathrm{in}\right.$.) $\mathrm{H}_{2} \mathrm{O}$. Other leak check procedures, subject to the approval of the Administrator, may be used. 
Figure 2-1 demonstrates a type $S$ pitot tube manometer assembly. The Tank Farm Vent and Balance group uses a siandard pitot tube as allowed for in Section 2.1 of Method 2. Capillary tubing or surge tanks are not used. No leak checks are accomplished.

3.2 Level and zero the manometer. Because the manometer level and zero may drift due to vibrations and temperature changes, make periodic checks during the traverse. Record all necessary data as shown in the example data sheet (Figure 2-5).

Not applicable. The digital micromanometer has negligible zero drift due to a built-in auto zeroing sequence that is initiated every 2 to 3 minutes. Span drift is typically $0.05 \%$ of range per ${ }^{\circ} \mathrm{C}$. The instrument is vibration and shock resistant.

3.3 Measure the velocity head and temperature at the traverse points specified by Method 1. Ensure that the proper differential pressure gauge is being used for the range of $\Delta \mathrm{P}$ values encountered (see Section 2.2). If it is necessary to change to a more sensitive gauge, do so, and remeasure the $\Delta P$ and temperature readings at each traverse point. Conduct a post-test leak-check (mandatory), as described in Section 3.1 above, to validate the traverse run.

Only velocity pressure is measured in current procedure. No temperature readings are taken. The digital micromanometer possesses sufficient accuracy. Post-test leak-checks are not conducted.

3.4 Measure the static pressure in the stack. One reading is usually adequate.

No static pressure reading is taken.

3.5 Determine the atmospheric pressure.

No atmospheric pressure reading is taken.

3.6 Determine the stack gas dry molecular weight. For combustion processes or processes that emit essentially $\mathrm{CO}_{2}, \mathrm{O}_{2}$ CO and $\mathrm{H}_{2}$ use Method 3. For processes emitting essentially air, an analysis need hot be conducted; use a dry molecular weight of $\mathbf{2 9 . 0}$. For other processes, other methods, subject to the approval of the Adninistrator, must be used.

Not applicable.

3.7 Obtain the moisture content from Reference Method 4 (or equivalent) or from Method 5.

Currently, no moisture content determination is made. It has not been determined if Method 4 has ever been used on Hanford Site stacks, but moisture content is addressed briefly in RHO-CD-1092, 200 Area Stack Sampler-Monitor Systems Upgrade: Generic Systems Applications, (RHO 1980a). The stack sample transfer lines are wrapped with heat tracing designed to keep the line at a constant $37.8^{\circ} \mathrm{C}\left(110^{\circ} \mathrm{F}\right)$. It is assumed that the heat trace is used to control moisture content. However, it is not known if the dew point of this stream has ever been determined and if this temperature will adequately protect the sample collection.

3.8 Determine the cross-sectional area of the stack or duct at the sampling location. Whenever possible, physically measure the stack dimensions rather than using blueprints. 
This is accomplished via known diameters. Physical measurements are not possible becallse of radiation hazards. This stack is $42 \mathrm{in.}$ in diameter.

\subsection{Calibration}

4.1 Type $S$ Pitot Tube.

Not applicable. Standard pitot tube is used.

\subsubsection{Type S Pitot Tube Assemblies.}

Not applicable. Standard pitot tube is used.

4.1.2 Calibration Setup. If the Type 5 Pitot tube is to be calibrated....

Not applicable. Standard pitot tube is used.

4.1.3 Calibration Procedure.

Not applicable. Standard pitot tube is used.

\subsubsection{Calculations.}

Not applicable. Standard pitot tube is used.

\subsubsection{Special considerations.}

Not applicable. Standard pitot tube is used.

4.1.6 Field Use and Recalibration.

Not applicable. Standard pitot tube is used.

4.2 Standard pitot tube (if applicable). If a standard pitot tube is used for the velocity traverse, the tube shall be constructed according to the criteria of Section 2.7 and shall be assigned a baseline coefficient value of 0.99 . If the standard pitot tube is used as part of the assembly, the tube shall be in an interference-free arrangement (subject to the approval of the Administrator).

Standard pitot tubes currently in use meet the criteria of Section 2.7. The manufacturer (Dwyer) recommends using a baseline coefficient of unity, which will produce a more conservative volumetric flow rate calculation than a coefficient of 0.99 . Currently, the calculation of volumetric flow rate, as presented in this Method 2 (using pitot tube coefficient, static pressure, barometric pressure, moisture content and temperature) is not conducted.

4.3 Temperature Gauges. After each field use, calibrate dial thermometers, liquid-filled bulb thermometers, thermocouple-potent ometer systems, and other gauges at a temperature within 10 percent of the average absolute stack temperature. For temperatures up to $405^{\circ} \mathrm{C}\left(761^{\circ} \mathrm{F}\right)$ use an ASTM mercury-in-glass reference thermometer, or equivalent, as a reference; alternatively, either a reference thermocouple and potentiometer (calibrated by NBS) or thermometric fixed points, e.g., ice bath and boiling water (corrected for barometric pressure) may be used. For temperatures above $405^{\circ} \mathrm{C}\left(761^{\circ} \mathrm{F}\right)$, use an NBS-calibrated reference thermocouple-potentiometer system or an alternate reference, subject to the approval of the Administrator.

1f, during calibration, the absolute temperatures measured with the gauge being calibrated and the reference gauge agree within 1.5 percent, the temperature data taken in the field shall be 
considered valid. Otherwise, the pollutant emission test shall either be considered invalid or adjustments (if appropriate) of the test results shall be made, subject to the approval of the Administrator.

Temperature gauges are not currently employed in the flow rate determinations for this stack.

4.4 Barometer. Calibrate the barometer used against a mercury barometer.

A barometer is not currently employed in the flow rate determinations for this stack.

5.0 Calculations

Carry out calculations, retaining at least one extra decimal figure beyond that of the acquired data. Round of figures after final calculation.

These calculations are not conducted for the 296-A-21 stack because the necessary parameters are not measured. Instead, traverse velocity pressures are converted to feet per minute flow rates, summed and averaged, and then converted to a total cubic feet per minute stack flow rate. Corrections are not made for temperature, pressure, moisture content or probe calibration coefficients.

\subsubsection{40 CFR 60, APPENDIX A, REFERENCE METHOD 2C: Comparison to Stack 296-A-22}

$1.0 \quad$ Principle and Applicability

1.1 Applicability.

1.1.1 The applicability of this method is identical to Method 2, except this method is limited to stationagy source stacks or ducts less than about 0.30 meters ( 12 in.) in diameter or $0.071 \mathrm{~m}^{2}\left(113 \mathrm{in}^{2}\right)$ in cross-sectional area, but, equal to or greater than about 0.10 meter (4 in.) in diameter or $0.0081 \mathrm{~m}^{2}\left(12.57 \mathrm{in}^{2}\right)$ in cross-sectional area.

296-A-22 has a known diameter of $0.20 \mathrm{~m}$ ( $8 \mathrm{in})$. Method $2 \mathrm{C}$ is the applicable stack flow measurement method.

1.1.2 The apparatus, calculations, and bibliography are the same as in Method 2, Sections 2 , $3,4,5$, and 6 except as noted in the following sections.

1.2 Principle. The average gas velocity in a stack or duct is determined from the gas density and from measurement of velocity heads with a standard pitot tube.

$2.0 \quad$ Apparatus

2.1 Standard Pitot Tube (instead of Type S). Use a standard pitot tube that meets the specifications of section 2.7 of Method 2. Use a coefficient value of 0.99 unless it is calibrated against another standard pitot tube with a NBS-traceable coefficient.

An ASME design stainless steel standard pitot tube that meets AMCA and ASHRAE specifications for maximum accuracy over a wide variety of flow conditions is used. The standard pitot tubes used for velocity traverses are Dwyer. Series 160 or equivalent and meet the criteria of Section 2.7 . The pitot tubes used do not require calibration and they use a manufacturer's recommended coefficient value of "l". The pitot 
tubes are used in conjunction with a digital micromanometer. The internal program of the micromanometer uses unity as the baseline coefficient.

2.2 Alternate Pitot Tube. A modified hemispherical-nosed pitot tube which features a shortened stem and enlarged impact and static pressure holes, may be used. This pitot tube is useful in liquid drop-laden gas streams when a pitot "back purge" is ineffective. Use a coefficient value of 0.99 unless the pitot is cal ibrated as mentioned in section 2.1 above.

Not applicable to 296-A-22.

Additional apparatus from Section 2 of Method 2

2.2 Differential Pressure Gauge. An inclined manometer or equivalent device is used. Most sampling trains are equipped with a 10-in. (water column) inclined-vertical manometer, having $0.01-$ in. $\mathrm{H}_{2} \mathrm{O}$ divisions on the $0-$ to $1-$ in. inclined scale, and $0.1-i n$. $\mathrm{H}_{2} \mathrm{O}$ divisions on the 1- to 10-ih. vertical scale. This type of manometer (or other gauge of equivalent sensitivity) is satisfactory for the measurement of $\triangle P$ values as (OW as $1.3 \mathrm{~mm}\left(0.05 \mathrm{in}\right.$.) $\mathrm{H}_{2} \mathrm{O}$. However, a differential pressure gauge of greater sensitivity shall be used (subject to the approval of the Administrator), if any of the following is found to be true: (1) the arithmetic average of all $\triangle P$ readings at the traverse points in the stack is less than $1.3 \mathrm{~mm}$ ( 0.05 in.) $\mathrm{H}_{2} \mathrm{O}_{\mathrm{i}}$ (2) for traverses of 12 or more points, more than 10 percent of the individual $\Delta P$ readings are below $1.3 \mathrm{~mm}(0.05 \mathrm{in.}) \mathrm{H}_{2} \mathrm{O}$; (3) for traverses of fewer than 12 points, more than one $\triangle P$ reading is below $1.3 \mathrm{~mm}\left(0.05^{2} \mathrm{in}\right.$.) $\mathrm{H}_{2} \mathrm{O}$. Citation 18 in section 6 describes commercially available instrumentation for the measurement of low-range gas velocities.

The device used is a digital micromanometer (Air-Neotronics Limited, Model MP20 SR) that has the capability of calculating and displaying corrected velocity readings, directly from pitot or total head probes, after density correction instructions are input into the built-in microcomputer. Using the Density Program, velocities can be displayed in any of 8 ranges spanning 300 to 20,000 feet per minute, resolving to $10 \mathrm{ft} / \mathrm{min}$. The instrument displays in any of 7 pressure scales, as follows:

\begin{tabular}{|c|c|c|c|}
\hline 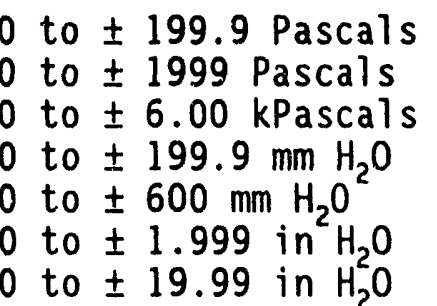 & $\begin{array}{c}\text { resolving t } \\
\text { " } \\
\text { " } \\
\text { " } \\
\text { " }\end{array}$ & $\begin{array}{l}\text { to } \\
\text { " } \\
" \\
" \\
"\end{array}$ & $\begin{array}{l}0.1 \mathrm{~Pa} \\
1 \mathrm{~Pa} \\
0.01 \mathrm{kPa} \\
0.1 \mathrm{~mm} \mathrm{H} \mathrm{H}_{2} \mathrm{O} \\
1 \mathrm{~mm} \mathrm{H}_{2} \mathrm{O}^{-} \\
0.001 \text { in } \mathrm{H}_{2} \mathrm{O} \\
0.01 \text { in } \mathrm{H}_{2} \mathrm{O}\end{array}$ \\
\hline
\end{tabular}

The instrument has negligible zero drift due to a built-in auto zeroing sequence that is initiated every 2 to 3 minutes. Span drift is typically $0.05 \%$ of range per ${ }^{\circ} \mathrm{C}$. The instrument is vibration and shock resistant. Currently, only pressure readings are taken with the instrument.

As an alternative to criteria (1) through ( 3 ) above, the following calculation may be performed to determine the necessity of using a more sensitive differential pressure gauge:

(see equation 40 CFR Pt. 60 App. A, Meth. 2, page 645)

Not applicable.

If $T$ is greater than 1.05, the velocity head data are unacceptable and a more sensitive differential pressure gauge must be used. 
NOTE: If differential pressure gauges other than inclined manometers are used

(e.g. magnehelic gauges) their cal ibration must be checked after each test series. To check the calibration of a differential pressure gauge, compare $\Delta P$ readings of the gauge with those of a gauge-oil manometer at a minimum of three points, approximately representing the range of $\Delta P$ values in the stack. If, at each point, the values of $\Delta P$ as read by the differential pressure

gauge and gauge-oil manometer agree to within 5 percent, the differential pressure gauge shall be considered to be in proper calibration. Otherwise, the test series shall either be voided, or procedures to adjust the measured $\triangle P$ values and final results shall be used subject to the approval of the Administrator.

Digital micromanometer is self-calibräting.

2.3 Teiperature Gaugc. A thermocouple, liquid-filled bulb thermometer, bimetallic thermometer, mercury-in-glass thermometer, or other gauge, capable of measuring temperature to within 1.5 percent of the minimum absolute stack temperisture shall be used. The temperature gauge shall be attached to the pitot tube such that the sensor tip does not touch any metal; the gauge shall be in an interference-free arrangement with respect to the pitot tube face openings (see Figure 2-1 and also figure 2-7 in Section 4). Al zernate positions may be used if the pitot tube-temperature gauge system is calibrated according to the procedure of Sertion 4. Provided that a difference of not more than 1 percent in the average velocity measurement is introduced, the temperature gauge need not be attached to the pitot tube; this al ternative is subject to the Approval of the Administrator.

\section{A temperature gauge is r.ot used in current practice.}

2.4 Pressure Prode and Gauge. A piezometer tube and mercury- or water-filled U-tube manometer corable of measuring stac's pressure to within $2.5 \mathrm{~mm}(0.1 \mathrm{in}$.) $\mathrm{Hg}$ is used. The static tap of a standard type pitot tube or one leg of a Type $S$ pitot tube with the face opening planes posirisied parallel to the gas flow may also be used as the pressure probe.

\section{Static pressure is not measured in current practice.}

2.5 Baroneter. A mercury, aneroid, or other barometer capable of measuring atmospheric pressure to within $2.5 \mathrm{~mm} \mathrm{Hg}(0.1 \mathrm{ir}$. . $\mathrm{Hg})$ may be used. In many cases, the barometric reading may be obtained from a nearby Hational Weather Service station, in which case the station value (wifich is the absolute barometric pressure) shall be requested and an adjustment for elevation differences between the weatier station and the sampling point shall be applied at a rate of minus $2.5 \mathrm{~mm}(0.1 \mathrm{in.}) \mathrm{Hg}$ per 30-meter (100 foot) elevation increase or vice-versa for eievation decrease.

\section{Barometric pressure is not measured in current practice.}

2.6 Gas Derisity Determination Equipment. Method 3 equipment, if needed (see Section 3.6 ), to determine the stack gas diy molecular weight, and Reference Method 4 or Method 5 equipment for moisture content determination; other methods may be used subject to approval of the Adninistrator.

\section{Gas density is not determined in current practice.}

2.7 Calibration Pilot Tube. When calibration of the Type $S$ pitot tube is necessary (see Section 4), a standard pitot tube is used as a reference. The standard pi tot tube shall, preferaoly, have a known coefficient, obtained either (1) directly from the National Bureau of Standards, Route 270, Quince Orchard Road, Gaithersburg, Maryland, or (2) by calibration against another standard pitot tube with an NBS-traceable coefficient. Alternatively, a standard pitot tube designed according to the criteria given in 2.7.1 through 2.7 .5 below and illustrated in figure 2-4 (see also citations 7,8 , and 17 in Section 6) may be used. Pitot tubes designed according to these specifications will have basel ine coefficients of about $0.98 \pm 0.01$.

Not necessary. Type $S$ pitot tube is not used.

2.7.1 Hemispherical (shown in Figure 2-4), ellipsoidal, or conical tip.

2.7.2 A minimum of six diameters straight run (based upon $D$, the external dianeter of the tube) between the tip and the static pressure holes. 
2.7.3 A minimum of eight diameters straight run between the static pressure holes and the centerline of the external tube, following the 90 degree bend.

2.7.4 Static pressure holes of equal size (approximately 0.10 ), equally spaced in a piezometer ring configuration.

2.7.5 Ninety degree bend, with curved or mitered junction.

2.8 Differential Pressure Gauge for Type S Pitot Tube Calibration. An inclined manometer or equivalent is used. If the single-velocity calibration technique is employed (see Section 4.1.2.3), the calibration differential pressure gauge shall be readable to the nearest $0.13 \mathrm{~mm} \mathrm{H}_{2} \mathrm{O}\left(0.005 \mathrm{in}\right.$. $\left.\mathrm{H}_{2} \mathrm{O}\right)$. For multivelocity calibration, the gauge shall be readable to the nearest $0.13 \mathrm{~mm} \mathrm{H}_{2} \mathrm{O}$ ? $0.005 \mathrm{in}$. $\left.\mathrm{H}_{2} \mathrm{O}\right)$ for $\Delta \mathrm{P}$ values between 1.3 and $25 \mathrm{~mm} \mathrm{H}_{2} \mathrm{O}(0.05$ and $1.0 \mathrm{in}$. $\mathrm{H}_{2} \mathrm{O}$ ), and to the nearest $1.3^{2} \mathrm{~mm} \mathrm{H}_{2} \mathrm{O}\left(0.05 \mathrm{in}\right.$. $\left.\mathrm{H}_{2} \mathrm{O}\right)$ for $\Delta \mathrm{P}$ values above $25 \mathrm{~mm} \mathrm{H}_{2} \mathrm{O}$ ( 1.0 in. $\left.H_{2} 0\right)$. A special, more sensitive gauge will be required to read $A P$ values below $1.3 \mathrm{~mm} \mathrm{H}_{2} \mathrm{O}^{2}\left[0.05\right.$ in. $\left.\mathrm{H}_{2} \mathrm{O}\right]$ ( (see Citation 18 in Section 6 ).

Not necessary. Type $S$ pitot tube is not used.

\subsection{Procedure}

Follow the general procedures in Section 3 of Method 2, except conduct the measurements at transverse points specified in Method 1A. The static and impact pressure holes of a standard pitot tube are susceptible to plugging in PM-laden gas streams. Therefore, the tester must furnish proof that the openings of the pitot tube have not plugged during the transverse period; this proof can be obtained by first recording the velocity head ( $\Delta p$ ) reading at the final transverse point, then cleaning out the impact and static holes of the pitot tube by "backpurging" with pressurized air, and final $y$ by recording another $\Delta p$ reading at the final transverse point. If the $\Delta p$ reading made after the air purge is within $5 \%$ of the reading during the transverse, then the transverse is acceptable. Otherwise, reject the rur. Note that if the $\Delta p$ at .the final transverse point is so low as to make this determination too difficult, then another transverse point may be selected. If "back-purging" at regular intervals is part of the procedure, then take comparative $\Delta p$ readings, as above, for the last two back purges at which suitable high $\Delta p$ readings are observed.

"Back-purging" is not accomplished; however, there is confidence that the stream is not PM laden because of the double HEPA filter system in place before the velocity measurement location.

\section{Procedure from Section 3 of Method 2}

3.1 Set up the apparatus as shown in figure 2-1. Capillary tubing or surge tanks installed between the manometer and pitot tube may be used to dampen $\Delta p$ fluctuations. It is recommended, but not required, that a pretest leak-check be conducted, as follows: (1) blow through the pitot impact opening unt il at least $7.6 \mathrm{~cm}(3 \mathrm{in.}) \mathrm{H}_{2} \mathrm{O}$ velocity pressure registers on the manometer; then, close off the impact opening. The pressare shall remain stable for at least 15 seconds; (2) do the same for the static pressure side, except using suction to obtain the minimum of $7.6 \mathrm{~cm}$ ( $3 \mathrm{in}$.) $\mathrm{H}_{2} \mathrm{O}$. Other leak check procedures, subject to the approval of the Administrator, may be used.

Figure 2-1 demonstrates a type $S$ pitot tube manometer assembly. The Tank Farm Vent and Balance group uses a standard pitot tube as allowed for in Section 2.1 of Method 2. Capillary tubing or surge tanks are not used. No leak checks are accomplished.

3.2 Level and zero the manometer. Because the manometer level and zero may drift due to vibrations and temperature changes, make periodic checks during the traverse. Record all necessary data as shown in the example data sheet (Figure 2-5).

Not applicable. The digital micromanometer has negligible zero drift due to a built-in auto zeroing sequence that is initiated every 2 to 3 minutes. Span drift is typically $0.05 \%$ of range per ${ }^{\circ} \mathrm{C}$. The instrument is vibration and shock resistant. 
3.3 Measure the velocity head and temperature at the traverse points specified by Method 1. Ensure that the proper differential pressure gauge is being used for the range of $\Delta P$ values encountered (see Section 2.2). If it is necessary to change to a more sensitive gauge, do so, and remeasure the $\triangle P$ and temperature readings at each traverse point. Conduct a post-test leak-check (mandatory), as described in Section 3.1 above, to validate the traverse run.

Only velocity pressure is measured in current procedure. No temperature readings are taken. The digital micromanometer possesses sufficient accuracy. Post-test leak checks are not conducted.

3.4 Measure the static pressure in the stack. One reading is usually adequate.

No static pressure reading is taken.

3.5 Determine the atmospheric pressure.

No atmospheric pressure reading is taken.

3.6 Determine the stack gas dry molecular weight. For combustion processes or processes that emit essentially $\mathrm{CO}_{2}, \mathrm{O}_{2}, \mathrm{CO}$ and $\mathrm{N}_{2}$, use Method 3 . For processes emitting essentially air, an analysis need hot be conducted; use a dry molecular weight of 29.0. For other processes, other methods, subject to the approval of the Administrator, must be used.

Not applicable.

3.7 Obtain the moisture content from Reference Method 4 (or equivalent) or from Method 5.

No moisture content determination is made.

3.8 Determine the cross-sectional area of the stack or duct at the sampling location. Whenever possible, physically measure the stack dimensions rather than using blueprints.

This is accomplished via known diameters. Physical measurements are not possible because of radiation hazards. This stack is 8 in. in diameter.

Calibiations and Calculations from Sections 4 and 5 of Method 2

\subsection{Calibration}

4.1 Type S Pitot Tube.

Not applicable. Standard pitot tube is used.

\subsubsection{Type $S$ Pitot Tube Assemblies.}

Not applicable. Standard pitot tube is used.

4.1.2 Calibration Setup. If the Type $S$ Pitot tube is to be calibrated.....

Not applicable. Standard pitot tube is used.

\subsubsection{Calibration Procedure.}

Not applicable. Standard pitot tube is used.

\subsubsection{Calculations.}

Not applicable. Standard pitot tube is used. 
4.1.5 Special considerations.

Not applicable. Standard pitot tube is used.

4.1.6 Field Use and Recalibration.

Not applicable. Standard pitot tube is used.

4.2 Standard pitot tube (if applicable). If a standard pitot tube is used for the velocity traverse, the tube shall be constructed according to the criteria of section 2.7 and shal! be assigned a basel ine coefficient value of 0.99 . If the standard pitot tube is used as part of the assembly, the tube shall be in an interference-free arrangement (subject to the approval of the Administrator).

Standard pitot tubes currently in use meet the criteria of Section 2.7. The manufacturer (Dwyer) recommends using a baseline coefficient of unity, which will produce a more conservative volumetric flow rate calculation than a coefficient of 0.99 . Currently, the calculation of volumetric flow rate, as presented in this Method 2 (using pitot tube coefficient, static pressure, barometric pressure, moisture content and temperature) is not conducted.

4.3 Temperature Gauges. After each field use, calibrate dial thermometers, liquid-filled bulb thermometers, thermocouple-potent iometer systems, and other gauges at a temperature within 10 percent of the average absolute stack temperature. For temperatures up to $405^{\circ} \mathrm{C}\left(761^{\circ} \mathrm{F}\right)$ use an ASTM mercury-in-glass reference thermometer, or equivalent, as a reference; alternatively, either a reference thermosouple and potentiometer (calibrated by NBS) or thermometric fixed points, e.g., ice bath and boiling water (corrected for barometric pressure) may be used. For temperatures above $405^{\circ} \mathrm{C}\left(761^{\circ} \mathrm{F}\right)$, use an NBS-calibrated reference thermocouple-potentiometer system or an alternate reference, subject to the approval of the Administrator.

If, during calibration, the absolute temperatures measured with the gauge being calibrated and the reference gauge agree within 1.5 percent, the temperature data taken in the field shall be considered valid. Otherwise, the pollutant emission test shall either be considered invalid or adjustments (if appropriate) of the test results shall be made, subject to the approval of the Administrator.

Temperature gauges are not currently employed in the flow rate determinations for this stack.

4.4 Barometer. Calibrate the barometer used against a mercury barometer.

A barometer is not currently employed in the flow rate determinations for this stack.

\subsection{Calculations}

Carry out calculations, retaining at least one extra decimal figure beyond that of the acquired data. Round off figures after final calculation.

These calculations are not conducted for the 296-A-21 stack because the necessary parameters are not measured. Instead, traverse velocity pressures are converted to feet-per-minute flow rates, summed and averaged, and then converted to a total-cubic-feet-per-minute stack flow rate. Corrections are not made for temperature, pressure, moisture content or probe calibration coefficients. 


\subsubsection{40 CFR 60, APPENDIX A, REFERENCE METHOD 1: Comparison to Stacks} 296-A-21 and 296-A-22

40 CFR 61.93 (b)(2)(i) states that "Reference Method 1 of Appendix A part 60 shall be used to select monitoring or sampling sites." For small stacks, Reference Method $1 A$ is used.

1.0 Principle and Applicability

1.1 Principle. To aid in the representative measurement of pollutant emissions and/or total volumetric flow rate from a stationary source, a measurement site where the effluent stream is flowing in a known direction is selected, and the cross-section of the stack is divided into a number of equal areas. A traverse point is then located within each of these equal areas.

1.2 Applicability. This method is applicable to flowing gas streams in ducts, stacks, and flues. The method cannot be used when: (1) flow is cyclonic or swirling (see section 2.4); (2) a stack is smaller than about 0.30 meter (12 in.) in diameter, or $0.079 \mathrm{~m}^{2}\left(113 \mathrm{in.}{ }^{2}\right)$ cross-sectional area; or (3) the measurement site is less than two stack or duct diameters downstream or less than a half diameter upstream from a flow disturbance.

296-A-21: This circular stack has a 1.07-m- (42-in-) diameter and, therefore, falls under the requirements of this Reference Method 1. 296-A-22: This circular stack has a diameter smaller than the $0.30 \mathrm{~m}$ (12 in) applicability criteria. Its diameter is only $0.20 \mathrm{~m}$ ( 8 in) and, therefore, falls under the requirements of Reference Method 1A. A point-by-point comparison of this stack with the requirements of Reference method $1 A$ is accomplished in Section 14.1.2.5 of this Chapter.

The requirements of this method must be considered before construction of a new facility from which emissions will be measured; failure to do so may require subsequent alterations to the stack or deviation from the standard procedure. Cases involving variants are subject to approval by the Administrator, U.S. Environmental Protection Agency.

$2.0 \quad$ Procedure

2.1 Selection of Measurement site. Sampling or velocity measurement is performed at a site located at least eight stack or duct diameters downstream and two diameters upstream from any flow disturbance such as a bend, expansion, or contraction in the stack, or from a visible flame. If necessary, an alternative location may be selected, at a position at least two stack or duct diameters downstream and a half diameter upstream from any flow disturbance. For a rectangular cross section, an equivalent diameter (De) shall be calculated from the following equation to determine the upstream and downstream distances:

$$
D_{e}=\frac{2 L W}{L+W}
$$

$L+W$ where $L=$ length $W=$ width.

An alternative procedure is available for determining the acceptability of a measurement location not meeting the criteria above. This procedure, determination of gas flow angles at the sampling points and comparing the results with acceptability criteria, is described in Section 2.5.

296-A-21 Velocity Measurement Site: The location used for building ventilation flow measurement is not on the stack. The location is approximately $61 \mathrm{~cm}(2 \mathrm{ft})$ from the fan on the rectangular duct transition boot leading to the stack. The transition boot is $0.61 \mathrm{~m} \times 0.61 \mathrm{~m}$ (24 in $\times 24$ in) square at the fan end and joins the stack at a $45^{\circ}$ angle. One equivalent duct diameter computes to be 
$1.2 \mathrm{~m}(4 \mathrm{ft})$. Therefore, the location does not meet the measurement site criteria because it is too close to the fan. Five measurements across the duct are taken from each of six equally-spaced ports on the side of this duct work.

296-A-21 Particulate Sampling Site: The building ventilation stack is approximately $6.7 \mathrm{~m}(22 \mathrm{ft})$ high. The fan section enters the stack approximately $3.0 \mathrm{~m}(10 \mathrm{ft})$ abuve the pad. The sampling probe is located approximately $1 \mathrm{~m}$ ( $42 \mathrm{in.}$ ) below the top of the stack and approximately $2.7 \mathrm{~m}$ (106 in) above the fan section entry. A flow measurement pitot tube enters the stack through a port approximately $61 \mathrm{~cm}(2 \mathrm{ft})$ above the 10-ft fan section. The sample probe location is, therefore, $2 \mathrm{~m}$ (78 in.) above the pitot tube. The stack diameter is $1 \mathrm{~m}(42 \mathrm{in.})$. Therefore, the sample probe is:

- $(78 / 42=1.8) 1.8$ duct diameters downstream of the flow disturbance presented by the pitot tube.

- $(106 / 42=2.5) 2.5$ duct diameters from the flow disturbance presented by the fan section entry.

- $(42 / 42=1) 1$ duct diameter upstream from the top of the stack.

The sample probe location requirement is not met (minimum of two duct diameters downstream from any flow disturbance).

2.2 Determining the Number of Traverse Points.

\subsubsection{Particulate traverses.}

Not applicable.

2.2.2 Velocity (Non-Particulate) Traverses. When velocity or volumetric flow rate is to be determined (but not particulate matter), the same procedure as that for particulate traverses (Section 2.2.1) is followed, except that Figure 1-2 may be used instead of Figure 1-1.

From Figure 1-2 of Method 1, a minimum of 16 velocity traverse points are needed for determining the volumetric flow rate. 30 velocity traverse points are taken in the fan section. Although this is a sufficient number of traverse points, the velocity measurement site is noncompliant.

2.3 Cross-sectional Layout and Location of Traverse Points.

2.3.1 Circular stacks. Locate the traverse points on two perpendicular diameters according to Table 1-2 and the example shown on figure 1-3. Any equation (for examples, see Citations 2 and 3 in the Bibliography) that gives the same values as those in Table 1-2 may be used in lieu of Table $1-2$.

Velocity traverses are not currently conducted on the circular stack section.

For particulate traverses, one of the diameters must be in a plane containing the greatest expected concentration variation, e.g., after bends, one diameter shall be in the plane of the bend. This requirement becomes less critical as the distance from the disturbance increases; therefore, other diameter locations may be used, subject to approval of the Administrator. 
In addition for stacks having diameters greater than $0.61 \mathrm{~m}(24 \mathrm{in.})$ no troverse points shall be located within 2.5 cent imeters (1.00 in.) of the stack walls; and for stack diameters equal to or less than $0.61 \mathrm{~m}$ ( $24 \mathrm{in.)}$, no traverse points shall be located within $1.3 \mathrm{~cm}(0.50 \mathrm{in.})$ of the stack walls. To meet these criteris, observe the procedures given below.

2.3.1.1 Stacks With Diameters Greater Than $0.61 \mathrm{~m}(24 \mathrm{in.})$. When any of the traverse points as located in Section 2.3 .1 fall within $2.5 \mathrm{~cm}(1.00 \mathrm{in.})$ of the stack walls, relocate them away from the stack walls to: (1) a distance of $2.5 \mathrm{~cm}(1.00 \mathrm{in.})$; or (2) a distance equal to the nozzle inside diameter, whichever is larger. These relocated traverse points (on each end of a diameter) shall be the "adjusted" traverse points.

Whenever two successive traverse points are combined to form a single adjusted traverse point, treat the adjusted point as two separate traverse points, both in the sampling (or velocity measurement) procedure, and in recording the data.

2.3.1.2 Stacks With Diameters Equal to or Less Than $0.61 \mathrm{~m}(24 \mathrm{in.})$. Follow the procedure in section 2.3.1.1, noting only that any "adjusted" points should be relocated away from the stack walls to: (1) a distance of $1.3 \mathrm{~cm}(0.50 \mathrm{in.})$; or (2) a distance equal to the nozzle inside diameter, whichever is larger.

2.3.2 Rectangular stacks. Determine the number of traverse points as explained in Sections 2.1 and 2.2 of this method. From Table 1-1, determine the grid configuration. Divide the stack cross-section into as many equal rectangular elemental areas as traverse points, and then locate a traverse point at the centroid of each equal area according to the example in Figure $1-4$.

Not applicable. 296-A-21 is not a rectangular stack.

If the tester desires to use more than the minimum number of traverse points, expand the "minimum number of traverse points" matrix (see Table 1-1) by adding the extra traverse points along one or the other or both legs of the matrix; the final matrix need not be balanced. For example, if a $4 \times 3$ "minimum number of points" matrix were expanded to 36 points, the final matrix could be $9 \times 4$ or $12 \times 3$, and would not necessarily have to be $6 \times 6$. After constructing the final matrix, divide the stack cross-section into as many equal rectangular, elemental areas as traverse points, and locate a traverse point at the centroid of each equal area.

The situation of traverse points being too close to the stack walls is not expected to arise with rectangular stacks. If this problem should ever arise, the Administrator must be contacted for resolution of the matter.

2.4 Verification of Absence of Cyclonic flow. In most stationary sources, the direction of stack gas flow is essentially parallel to the stack walls. However, cyclonic flow may exist (1) after such devices as cyclones and inertial demisters following venturi scrubbers, or (2) in stacks having tangential inlets or other duct configurations which tend to induce swirling; in these instances, the presence or absence of cyclonic flow at the sampling location must be determined. The following techniques are acceptable for this determination.

\section{The verification of the presence or absence of cyclonic flow has not} been made.

Level and zero the manometer. Connect a Type S pitot tube to the manometer. Position the Type $S$ pitot tube at each traverse point, in succession, so that the planes of the face openings of the pitot tube are perpendicular to the stack cross-sectional plane; when the Type $S$ pitot tube is in this position, it is at " $0^{\circ}$ reference." Note the differential pressure (AP) reading at each traverse point. If a null (zero) pitot reading is obtained at $0^{\circ}$ reference at a given traverse point, an acceptable flow condition exists at that point. If the pitot reading is not zero at $0^{\circ}$ reference, rotate the pitot tube (up to $\pm 90^{\circ}$ yaw angle), until a null reading is obtained. Carefully determine and record the value of the rotation angle $(a)$ to the nearest degree. After the null technique has been applied at each traverse point, calculate the average of the absolute values of $\alpha_{i}$ assign a values of $0^{\circ}$ to those points for which no rotation was required, and include these in the overall average. If the average value of $a$ is greater than $20^{\circ}$, the overall flow condition in the stack is unacceptable and alternative methodology, subject to the approval of the Aciministrator, must be used to perform accurate sample and velocity traverses. 
The alternative procedure described in section 2.5 may be used to determine the rotetion angles in lieu of the procedure described above.

2.5 Alternative Measurement site Selection Procedure. This alternative applies to sources there measurement locations are less than 2 equivalent stack or duct dianeters downstream or less than $1 / 2$ duct diameter upstrean from a flow disturbance. The alternative should be limited to ducts larger than $24 \mathrm{in.}$ in diameter where blockage and wall effects are minimal.

A directional flow sensing probe is used to measure pitch and yaw angles of the gas flow at 40 or more traverse points; the resultant angle is calculated and compared with acceptable criteria for mean and standard deviation.

An alternative measurement site evaluation has not been conducted for the 296-A-21 stack.

\subsubsection{40 CFR 60, APPENDIX A, REFERENCE METHOD 1A: Comparison to Stack 296-A-22}

\subsection{Applicability and Principle}

1.1 The applicability and principle of this method are identical to Method 1, except this method's applicability is limited to stacks or ducts less than about 0.30 meters ( 12 in.) in diameter or $0.071 \mathrm{~m}^{2}$ (113 in. ${ }^{2}$ ) in cross-sectional asea, but equal to or greater than about 0.10 meter (4 in.) in diameter or $0.0081 \mathrm{~m}^{2}\left(12.57 \mathrm{in.}^{2}\right.$ ) in cross-sectional area.

The vessel vent stack is $20.3 \mathrm{~cm}$ ( 8 in.) in diameter, therefore this method is applicable for the determination of a velocity measurement site and for the determination of the required number of velocity traverse points.

1.2 In these small diameter stacks or ducts, the conventional Method 5 stack assembly (consisting of a Type $S$ pitot tube attached to a sampling prabe, equipped with a nozzle and thermocouple) blocks a significant portion of the cross section of the duct and causes inaccurate measurements. Therefore, for particulate matter (PM) sampling in small stacks or ducts, the gas velocity is measured using a standard pitot tube downstream of the actual emission sampling site. The straight run of duct between the PM sampling and velocity measurement site allows the flow profile, temporarily disturbed by the presence of the sampling probe, to redevelop and stabilize.

1.3 The cross-sectional layout and location of transverse points and the verification of absence of cyclonic flow are the same as in Method 1, Section 2.3 and 2.4, respectively. Differences from Method 1, except as noted, are given below.

\subsection{Procedure}

2.1 Selection of Sampling and Measuring sites.

2.1.1 PM Measurements. Select a PM sampling site located preferably at least 8 equivalent stack or duct diameters downstream and 10 equivalent diameters upstream from any flow disturbances such as bends, expansion, or contractions in the stack, or from a visible flame. Next locate the velocity site 8 equivalent diameters downstream of the PM sampling site. If such locations are not available, select an alternate PM sampling site that is at least 2 equivalent stack or duct diameters downstream and 2 and $1 / 2$ stack diameters upstream from any flow disturbances. Then, locate the velocity measurement site 2 equivalent stack diameters downstream from the sampling site. follow Section 2.1 of Method 1 for calculating equivalent diameters for a retangular cross section.

The sample probe location within the vessel vent stack is located on the fourth floor of the condenser room. The closest flow disturbances are as follows:

- The sample return line enters the stack approximately $0.61 \mathrm{~m}$ $(2 \mathrm{ft})$ upstream of the probe location. This equates to three stack diameters. 
The elbow in the vessel vent that takes the stack outside the building is approximately $1.4 \mathrm{~m}$ (56 in.) downstream of the probe. This equates to seven stack diameters.

The sample probe location does not meet the preferred criterla of Method 1A, Section 2.1.1, but does meet the alternative location criteria. The alternative requires a larger number of traverses be taken.

The port available for use in periodic stack velocity measurements is located on the fourth floor of the condenser room, $0.30 \mathrm{~m}(1 \mathrm{ft})$ above the sampler probe. This location is $1.1 \mathrm{~m}$ ( $44 \mathrm{in})$ below the flow disturbance presented by the elbow that directs the flow outside the building. In stack diameters, these distances place this location at one and one-half stack diameters downstream of the probe and five and one-half stack diameters upstream of the elbow.

The velocity measurement location does not meet the preferred criteria of Method 1A, Section 2.1.1, but does meet the alternative location criteria. The alternative requires a larger number of traverses be taken.

\subsection{Determining the Number of Traverse Points}

2.2.2 PM Sampling (Steady Flow) or Velocity Measurements. Use Figure 1-2 of Method 1 to determine the number of traverse points, following the same procedure used for PM traverses as described in section 2.2.1 of Method 1. When the optimum duct diameter location criteria can be satisfied, the minimum number of traverse points required is eight for circular ducts and nine for rectangular ducts.

From Figure 1-2 of Method 1, 16 velocity traverse points are needed across the cross-section of the 296-A-22 stack. Currently, 16 traverse points are not used.

Method 1, Section 2.3 Cross-sectional Layout and Location of Traverse Points.

2.3.1 Circular Stacks. Locate the traverse points on two perpendicular diameters according to Table 1-2 and the example shown on Figure 1-3. Any equation (for examples, see Citations 2 and 3 in the Bibliography) that gives the same values as those in Table 1-2 may be used in lieu of Table 1-2.

Velocity traverses are not currently conducted on two perpendicular diameters on the 296-A-22 stack.

For particulate traverses, one of the diameters must be in a plane containing the greatest expeciced concentration variation, e.g., after bends, one diameter shall be in the plane of the bend. This requirement becomes less critical as the distance from the disturbance increases; therefore, other diameter locations may be used, subject to approval of the Administrator.

In addition for stacks having diameters greater than $0.61 \mathrm{~m}(24 \mathrm{in.}$ ) no traverse points shall be located within 2.5 centimeters (1.00 in.) of the stack walls; and for stack diameters equal to or less than $0.61 \mathrm{~m}(24 \mathrm{in.})$, no traverse points shall be located within $1.3 \mathrm{~cm}(0.50 \mathrm{in.})$ of the stack walls. To meet these criteria, observe the procedures given below.

2.3.1.1 Stacks With Diameters Greater Than $0.61 \mathrm{~m}(24 \mathrm{in.})$. When any of the traverse points as located in Section 2.3 .1 fall within $2.5 \mathrm{~cm}$ ( $1.00 \mathrm{in}$.) of the stack walls, relocate them away from the stack walls to: (1) a 
distance of $2.5 \mathrm{~cm}(1.00 \mathrm{in.})$; of (2) a distance equal to the nozzle inside diemeter, whichever is larger. These relocated traverse points (on each end of a diameter) shall be the "adjusted" traverse points.

Whenever two successive traverse points are combined to form a single adjusted traverse point, treat the adjusted point as two separate traverse points, both in the sampling (or velocity measurement) procedure, and in recording the data.

2.3.1.2 Stacks With Diameters Equal to or Less Than $0.61 \mathrm{~m}(24 \mathrm{in.})$. Follow the procedure in section 2.3.1.1, noting only that any "odjusted" points should be relocated away from the stack walls to: (1) distance of $1.3 \mathrm{~cm}(0.50 \mathrm{in.}) ;$ or (2) a distance equal to the nozzle inside dianeter, whichever is larger.

2.3.2 Rectangular stacks. Determine the number of traverse points as explained in sections 2.1 and 2.2 of this method. From Table 1-1, determine the grid conifiguration. Divide the stack cross-section into as many equal rectangular elemental areas as traverse points, and then locate a traverse point at the centroid of each equal area according to the exemple in Figure 1.4 .

Not applicable. 296-A-22 is not a rectangular stack.

If the tester desires to use more than the minimum number of traverse points, expand the "minimum number of traverse points" matrix (see Table 1-1) by adding the extra traverse points along one or the other or both legs of the matrix; the final matrix need not be balanced. For example, if a $4 \times 3$ "minimum number of points" matrix were expanded to 36 points, the final matrix could be $9 \times 4$ or $12 \times 3$, and would not necessarily have to be $6 \times 6$. After constructing the final matrix, divide the stack cross-section into as many equal rectangular, elemental areas as traverse points, and locate a traverse point at the centroid of each equal area.

The situation of traverse points being too close to the stack walls is not expected to arise with rectangular stacks. If this problem should ever arise, the Acministrator must be contacted for resolution of the matter.

2.4 Verification of Absence of Cyclonic flow. In most stationary sources, the direction of stack gas flow is essentially parallel to the stack walls. However, cyclonic flow may exist (1) after such devices as cyclones and inertial demisters following venturi scrubbers, or (2) in stacks having tangential inlets or other duct contigurations which tend to induce swirling; in these instances, the presence or absence of cyclonic flow at the sampling location must be determined. The following techniques are acceptable for this determination.

The verification of the presence or absence of cyclonic flow has not been made.

Level and zero the manometer. Connect a Type $S$ pitot tube to the manometer. Position the Type $S$ pitot tube at each traverse point, in succession, so that the planes of the face openings of the pitot tube are perpendicular to the stack cross-sectional plane; when the Type $S$ pitot tube is in this position, it is at " $0^{\circ}$ reference." Note the differential pressure $\left(\triangle P\right.$ ) reading at each traverse point. "If a null (zero) pitot reading is obtained at $0^{\circ}$ reference at a given traverse point, an acceptable flow condition exists at that point. If the pitot reading is not zero at $0^{\circ}$ reference, rotate the pitot tube (up to $\pm 90^{\circ}$ yaw angle), until a null reading is obtained. Carefullv determine and record the value of the rotation angle $(a)$ to the nearest degree. After the null technique has been apol ied at each traverse point, calculate the average of the absolute values of $\alpha_{i}$ assign $\alpha$ values of $0^{\circ}$ to those points for which no rotation was required, and include these in the overall average. If the average value of $a$ is greater than $20^{\circ}$, the overall flow condition in the stack is unacceptable and alternative methodology, subject to the approval of the Administrator, must be used to perform accurate sample and velocity traverses.

The alternative procedure described in section 2.5 may be used to determine the rotation angles in lieu of the procedure described above.

2.5 Alternative Measurement Site Selection Procedure. This alternative applies to sources where measurement locations are less than 2 equivalent stack or duct diameters downstream or less than $1 / 2$ duct diameter upstream from a flow disturbance. The alternative should be limited to ducts larger than $24 \mathrm{in}$. in diameter where blockage and wall effects are minimal. A directional flow sensing probe is used to measure pitch and yaw angles of the gas flow at 40 or more traverse points; the resultant angle is calculated and compared with acceptable criteria for mean and standard deviation. 
An alternative measurement site evaluation has not been conducted for the 296-A-22 stack.

14.1.2.6 ANSI N13.1-1969: Comparison with Stacks 296-A-21 and 296-A-22

ANSI M13.1-1969. Guide to Samoling Airborne Rodioactive Materials in Nuclear Facillities

4.2.1.2 Semoling from ouct or Exhaust Stack Sampling point should be a minimum of five diameters (or 5 times the major dimension for rectangular ducts) downstream from abrupt changes in flow direction or prominent transitions.

296-A-21 Particulate Sampling Site: The building ventilation stack is approximately $6.7 \mathrm{~m}(22 \mathrm{ft})$ high. The fan section enters the stack approximately $3.0 \mathrm{~m}(10 \mathrm{ft})$ above the pad. The sampling probe is located approximately $1 \mathrm{~m}$ ( $42 \mathrm{in}$.) below the top of the stack and approximately $2.7 \mathrm{~m}$ (106 in) above the fan section entry. A flow measurement pitot tube enters the stack through a port approximately $61 \mathrm{~cm}(2 \mathrm{ft})$ above the $10-\mathrm{ft}$ fan section. The sample probe location is, therefore, $2 \mathrm{~m}$ ( $78 \mathrm{in}$.) above the pitot tube. The stack diameter is $1 \mathrm{~m}(42 \mathrm{in.})$. Therefore, the sample probe is :

- $\quad(78 / 42=1.8) 1.8$ duct diameters downstream of the flow disturbance presented by the pitot tube.

- $\quad(106 / 42=2.5) 2.5$ duct diameters from the flow disturbance presented by the fan section entry.

- $\quad(42 / 42=1) 1$ duct diameter upstream from the top of the stack.

The sample probe location requirement is not met (minimum of five duct diameters downstream from major flow disturbances). However, 40 CFR $\$ 61.93$ (a) (2)(i) requires use of 40 CFR 60, Appendix A, Method 1 to determine site selection. Refer to Section 14.1.2.4 for assessment.

296-A-22 Particulate Sampling Site: The sample probe location within the vessel vent stack is located on the fourth floor of the condenser room. The closest flow disturbances are as follows:

- The sample return line enters the stack approximately $0.61 \mathrm{~m}$ $(2 \mathrm{ft})$ upstream of the probe location. This equates to three stack diameters.

- The sample probe is approximately $2.46 \mathrm{~m}$ (97 in) above the fan 4"-to-8" transition. This equates to about 12 duct diameters.

- The elbow in the vessel vent that takes the stack outside the building is approximately $1.4 \mathrm{~m}$ (56 in.) downstream of the probe. This equates to seven stack diameters.

Therefore, the sample probe location is more than five duct diameters downstream of any abrupt changes in flow direction or 
prominent transitions. However, 40 CFR $\$ 61.93$ (a)(2)(i) infers use of 40 CFR 60, Appendix A, Method 1A to determine site selection. Refer to Section 14.1.2.5 for assessment.

4.2.2 Samples should be representative with respect to physical and chemical composition of airstream.

Particle size studies are currently under way. This study is under the direction of the Environmental Protection group.

4.3.1 Sensitivity and accuracy of the analytical or counting method will determine the minimum volume of air which must be sampled to obtain the requisite accuracy and precision of results.

The minimum volume of air has been established as that which passes through the sampling system at 2.2 CFM in one week's time $(22,176 \mathrm{cu} \mathrm{ft})$.

4.3.2 If possible, the sample should be large enough to permit $1 / 10$ the permissible level to be determined with reliability.

The frequency of the record sample filter and silver zeolite cartridge exchange follows:

- If at all possible, record air samples are left running for a full 168-hour ( 7 days) week to ensure a representative sample.

- The silver zeolite cartridges are exchanged as follows:

- When the cartridges have been in the sample for 1 week.

- When radiation readings indicate a buildup of greater than $16 \mathrm{mR} /$ hour within the last 8 hours.

- When requested by operations management.

5.2.2 Airborne particulate matter should be evaluated and characterized at regular intervals and before any anticipated process change.

See response under ANSI N13.1-1969, Section 4.2.2.

5.2.2.1 Appropriate filtration should be chosen for sampling.

47-mm Versapor 3000 or equivalent air sample filters are used for the record sampler. This filter is a membrane filter good for collecting $0.3-\mu \mathrm{m}$ size particles with a collection efficiency of $95.8 \%$.

5.2.2.1.7 Filter holders and support should be chosen for proper chemical compatibility, mechanical strength, sealing, and ease of operation in changing filters. Sample air movers should have the capability of delivering the necessary air flow against the resistance of the sampling system.

The record sample holder is described as follows:

- Large outside diameter with knurled outer ring for ease of opening.

- Rubber "0" ring gaskets used to seal the sample holder. 
- Fine mesh screen behind the sample filter to keep the sample a constant distance from the inlet.

- Sample vacuum side is connected by a flexible line for ease of access.

Proper location and choice of flow measurement device and flow rate control is important.

The record sample vacuum system consists of the following components:

- Rotameter (FI): Reads out in SCFH or CFM of air flow through the sample paper. Certified Accurate to $\pm 10 \%$ @ 2.2 SCFM. Operating range: 0.0 to 3.0 SCFM $\pm 5 \%$.

- Gas Meter Totalizer (FIQ): Industry Standard gas meter. Reads out in $\mathrm{m}^{3}$. Measures the total volume of air pulled through the sample filter. Certified Accurate to $\pm 5 \%$ @ 2.2 SCFM.

- Flow Alarm Switch (FAS): Trips an alarm at the loss of flow (@1.25 CFM) due to vacuum pump failure and/or sample filter clogging. Accurate to within $\pm 10 \%$.

- Vacuum Line to the Vacuum Pump (Tygon): Equipped with a standard quick-disconnect for connection to al ternative pumps and for sample filter retrieval.

- Stack Flow Switch: Controls a "switched" power outlet providing power to the record sample vacuum pump. Automatically shuts down the record sample vacuum pump when the stack fans cease operation.

- Record Sample Timer: Provides integrated timing of power supplied to the "switched" power outlet. Resettable five-digit to 99999. Normally reset to zero when the record sample is exchanged. Certified accurate to $\pm 1 \%$.

5.3 Airborne radioactive gases or volatile materials should be sampled by an appropriate method if present.

296-A-22: Silver zeolite cartridges are used and are designed to collect volatile radionuclides ${ }^{129} \mathrm{I},{ }^{131} \mathrm{I},{ }^{125} \mathrm{Sb},{ }^{113} \mathrm{Sn},{ }^{103} \mathrm{Ru}$, and ${ }^{106} \mathrm{Ru}$. Westinghouse Hanford uses two manufacturers at this time:

SAIC/RADECO

10373 Roselle Street

San Diego, CA 92121

Tel: (619) 458-3831

or

HI-Q Environmental Products Co

PO Box 2847

LaJolla, Ca 92038-2847

Tel: (619) 270-9675 
The gross filter efficiency of a silver zeolite cartridge is based on the particular absorbed/adsorbed radionuclide being evaluated and the porosity of the filter. For uses at the Hanford Site (i.e., ruthenium, iodine) the efficiency is $99.2 \%$ to $99.98 \%$ (taken from Table $0-2$ of Air Sampling Instruments, ACGIH, 7 th edition, 1989).

Ammonia releases are continuously monitored on this stack.

296-A-21: The monitoring/sampling system for the building vent stack does not have silver zeolite cartridges for monitoring volatile radionuclides because they are not expected to be present within the secondary containment of the building. Air sampling and monitoring stations are located throughout the building for the detection of ammonia and high radionuclide concentrations (refer to Section 4.1.1.2 of this FEMP).

Appendix A: Guides for Sampling from Ducts and stacks

A1. Minimization of the length and bends of sample delivery lines will contribute to representative sampling.

As specified on drawings sample tubing $(1.0 \mathrm{in.} 00 \times 0.065$ wall SST (OMML), is installed with a minimum number of bends using a minimum bend radius of $10 \mathrm{in.}(25.4 \mathrm{~cm})$. Sample lines are kept as short as practically possible.

A2. Selection of sampling position along a stack.

See response under ANSI N13.1-1969, Section 4.2.1.2.

A3.1 Velocity and flow distribution should be known for the sampling point, and particle and gaseous composition should be representative.

Particle size studies are explained in the response under ANSI N13.1-1969, Section 4.2.2. Velocity measurements are accomplished by Procedure 7-GN-56, Airflow Capacity and Distribution Tests.

296-A-22: The vessel ventilation exhauster nominally delivers $19.82 \mathrm{~m}^{3} / \mathrm{min}\left(700 \mathrm{ft}^{3} / \mathrm{min}\right)$ at $25.4 \mathrm{~cm}$ (10 in.) of water gauge. Stack flow rates are measured quarterly using Hanford Maintenance Procedure 7-GN-56, Airflow Capacity and Distribution Tests (WHC 1989a). The following information, obtained from stack flow rate measurement data, demonstrates the flow rate within the vessel vent stack.

- The average of 115 stack flow measurements taken between September 1987 and January 1991 was computed to be $723 \mathrm{ft}^{3} / \mathrm{min}$.

- The maximum of these 115 measurements was $829 \mathrm{ft}^{3} / \mathrm{min}$.

- The minimum of these 115 measurements was $598 \mathrm{ft}^{3} / \mathrm{min}$.

Comparison of these measurements to Table $A 1$ in the Standard shows that the flow is turbulent. The ANSI Standard states in Section A3.3.2 that "as the flow becomes more turbulent, the velocity (profile) becomes 
more nearly uniform across the duct". The closest flow disturbances are described under Method 1A in Section 14.1.2.5 of this chapter.

296-A-21: The bujlding ventilation stack has a nominal volumetric flow rate of $19,300 \mathrm{ft}^{3} / \mathrm{min}$. Stack flow rates are measured quarterly using Hanferd Maintenance Procedure 7-GN-56, Airflow Capacity and Distribution Tests (WHC 1989a). The following information, obtained from stack flow rate measurement data, demonstrates the flow rate within the building vent stack.

- The average of 13 quarterly stack flow measurements taken between September 1987 and August 1991 was computed to be $18,970 \mathrm{ft}^{3} / \mathrm{min}$.

- Thr maximum of these 13 measurements was $22,106 \mathrm{ft}^{3} / \mathrm{min}$.

- The minimum of these 13 measurements was $14,294 \mathrm{ft}^{3} / \mathrm{min}$.

Comparison of these measurements to Table Al in the Standard shows that the flow is turbulent. The ANSI Standard states in Section A3.3.2 that "as the flow becomes more turbulent, the velocity (profile) becomes more nearly uniform across the duct". The closest flow disturbances are described under Method 1 in Section 14.1.2.4 of this Chapter.

A3.2 A multiole number of withdrawal points each represeiting approximately equal areas based on the duct or stack dimensions is desirable.

296-A-22: The probe has two nozzles centered in equal annular areas. This is as recommended in this section of the ANSI Standard for this size stack ( 8 in.).

296-A-21: The probe has five nozzles centered in equal annular arkas. This is the correct number of probes recommended in this section of the ANSI Standard for this size stack (42 in).

A3.3 The velocity distribution across the duct or stack must be known, preferably through direct velocity traverses at the section chosen for the sampling station. The velocity distribution must be known in order to establish the rate of sample withdrawal to maintain isokinetic flow for the sample probe and to determine the integrated flow of radioactive material through the system from the sample taken.

The velocity distribution is not known. However, it is known that the stack flow is turbulent (see response under $A 3.1$ ). As stated in the ANSI Standard, Section A3.3.2, "as the flow becomes more turbulent, the velocity becomes more nearly uniform across the duct."

296-A-22: Based on a uniform velocity profile, and on the probe nozzle sizes, it can be shown thi the sampling probe draws an isokinetic sample, under ideal conditions, at a stack flow rate of $775 \mathrm{ft}^{3} / \mathrm{min}$. The average of 115 stack flow measurements taken between September 1987 and January 1991 was computed to be $723 \mathrm{ft}^{3} / \mathrm{min}$.

296-A-21: Based on a uniform velocity profile, and on the probe nozzle sizes, it can be shown that the sampling probe draws an isokinetic sample, under ideal conditions, at a stack flow rate of $29,801 \mathrm{ft}^{3} / \mathrm{min}$. 
The averaye of 13 quarterly stack flow measurements taken between September 1987 and August 1991 was computed to be $18,970 \mathrm{ft}^{3} / \mathrm{min}$.

13.4 Sumpling probe configuration is recommended by figures in this standard, with minimum radius bends and precisely tapered proke end edges.

In general any bend or curvature in the probe and sample lines should be designed to have a curvature of at least five times the inside diameter of the line or probe.

The diameters and radii of the vessel vent sampler probe nozzles as well as the minimum recommended curvature radii are detailed in Table 14-1, Vessel Vent Sampler Probe Design. The table shows that the curvature radius requirement is satisfied for the vessel vent stack.

Table 14-1. Vessel Vent Sampler Probe Design.

\begin{tabular}{|c|c|c|c|c|}
\hline Probe & Location & $\begin{array}{c}\text { Diameter } \\
\text { (in.) }\end{array}$ & $\begin{array}{c}\text { Design } \\
\text { curvature } \\
\text { radi } \\
\text { (in.) }\end{array}$ & $\begin{array}{c}\text { Minimm recommended } \\
\text { curvature } \\
\text { radi } \\
\text { (in.) }\end{array}$ \\
\hline A & Middle & $0.452-0.454$ & 3.75 & $2.26-2.27$ \\
\hline B & Outside & $0.553-0.555$ & 5 & $2.77-2.78$ \\
\hline
\end{tabular}

The diameters and radii of the building vent sampler probe nozzles as well as the minimum recommended curvature radi $i$ are detailed in Table 14-1, Vessel Vent Sampler Probe Design. As can be seen, probes $A, B, D$, and $E$ are each borderline cases for meeting the curvature radius requirement.

Table 14-2. Building Ventilation Sampler Probe Design.

\begin{tabular}{|c|c|c|c|c|}
\hline Probe & Location & $\begin{array}{c}\text { Dianeter } \\
\text { (in.) }\end{array}$ & $\begin{array}{c}\text { Design } \\
\text { curvature } \\
\text { radii } \\
\text { (in.) }\end{array}$ & $\begin{array}{c}\text { Minimum } \\
\text { recommended } \\
\text { curvature } \\
\text { radii } \\
\text { (in.) }\end{array}$ \\
\hline A and E & Outside & $0.302-0.304$ & $1.625-1.375$ & $1.51-1.52$ \\
\hline$B$ and D & Next to outside & $0.266-0.268$ & $1.625-1.375$ & $1.33-1.34$ \\
\hline C & Middle & $0.201-0.203$ & $1.625-1.375$ & $1.005-1.015$ \\
\hline
\end{tabular}

B1. In every case where sampling delivery lines are required, an evaluation should be made of particle deposition in these lines. The principal mechanisms by which particles are deposited are gravity settling and brownian diffusion when the flow is laminar, and by turbulent deposition when the flow is turbulent. Sampling line length should be kept to a minimum length. An estimate of the fraction of particles deposited in sampling lines under various conditions should be made using the experimental data presented in this appendix.

The estimate has not been accomplished. See explanation under ANSI N13.1-1969, Section 4.2.2 above. Particle size and density are not known. However, an estimate may be made by using Table B-3 in the ANSI Standard together by assuming, due to turbulent flow, 
that losses due to gravity settling and Brownian diffusion are insignificant. This estimate is done in the following section B4.

B2. Gravity Deposition: From the equations in this section and from the data in Table B-1, one can determine the relative importance of gravity settling of particles in the bottom of the tubirg. This phenomenon occurs only when the flow is laminar in nature.

The flow in the sample lines has been determined to be turbulent.

B3. Brownian Diffusion: Velocities must be kept high enough to avoid appreciable losses by Bromian diffusion.

The sample velocity within the tubing is substantially high enough to avoid the effects of Brownian diffusion. The flow is turbulent and as explained in the ANSI standard, Section BI, "The principle mechanisms by which particles are deposited are... by turbulent deposition when the flow is turbulent."

B4. Turbulent Deposition: Particles carried in turbulent flow will be deposited on the talls of a conduit to a greater or lesser degree, depending on particle size and density, the average velocity of the air, and the diameter and length of the conduit.

Particle size and density are not known. However, an estimate may be made by using Table B-3 in the ANSI Standard together with the following facts and assumptions:

- The sampling line is $2.2 \mathrm{~cm}$ in diameter.

- The sampling line length is less than $500 \mathrm{~cm}$.

- The HEPA filters remove all particles greater in size than $0.3 \mu \mathrm{m}$.

- The flow rate is greater than $1000 \mathrm{~cm}^{3} / \mathrm{s}$.

The resulting fraction of particles lost in the sampling line as determined from this table is less than 0.01 . The density of the particles do not affect this result.

B5. Deposition in Elbows in Sample Delivery Lines: Elbows in sampling lines should be avoided if at all possible. When required, the bend radius of the elbow should be as long as practical, and design flow rates through any line containing an elbow should be kept low. When possible, the sampler installation should allow for probe removal in order to evaluate the losses in the probe entry elbow and to permit cleaning.

The probes are not removed for cleaning at the present time. There are elbows in the sampling lines but the bend radii are kept greater than 5 tube-diameters. The flow is not kept low, the flow is turbulent.

\subsubsection{40 CFR 61, APPENDIX B, METHOD 114: Comparison With Stacks 296-A-22 and 296-A-21}

1.0 Purpose and Background

This method provides the requirements for: (1) Stack monitoring and sample collection methods appropriate for radionuclides; (2) radiochemical methods which are used in determining the amounts of radionuclides collected by the stack sampling and; (3) quality assurance methods which are conducted in conjunction with these measurements. These methods are appropriate for emissions for stationary sources. A list of references is provided. 
Many different types of facilities release radionuclides into air. These radionuclides differ in the chemical and physical forms, half-lives and type of radiation emitted. The appropriate combination of semple extraction, collection and analysis for an individual radionuclide is dependent upon many interrelated factors including the mixture of other radionuclides present. Because of this wide range of conditions, no single method for monitoring or sample collection and analysis of a radionuclide is applicable to all types of facilities. Therefore, a series of methods based on "principles of measurement" are described for monitoring and sample collection and analysis thich are applicable to the measurement of radionuclides found in effluent streams at stationary sources. This approach provides the user with the flexibility to choose the most appropriate combination of monitoring and sample collection and analysis methods which are applicable to the affluent strean to be measured.

Monitoring and sample collection methods are described based on "principles of monitoring and sample collection" which are applicable to the measurement of radionuclides from effluent streams at stationary sources. Radionuclides of most elements will be in the particulate form in these effluent streans and can be readily collected using a suitable filter media. Radionuclides of hydrogen, oxygen, carbon, nitrogen, the noble gases and in some circumstances iodine will be in the gaseous form. Radionuclides of these elements will require either the use of an in-line or off-line monitor to directly measure the radionuclides, or suitable sorbers, condensers or bubblers to collect the radionuclides.

2.1 Radionuclides as Particulates. The extracted effluent stream is passed through a filter media to remove the particulates. The filter must have a high efficiency for removal of sub-micron particles. The guidance in ANSI N13.1-1969 shall be followed in using filter media to collect particulates (incorporated by reference-see $\$ 61.18$ ).

See response under ANSI N13.1-1969, Section 5.2.2.1 above.

\subsection{Radionuclides as Gases.}

Silver zeolite cartridges are used on the 296-A-22 sampling system. These cartridges are designed to collect ${ }^{129} \mathrm{I},{ }^{131} \mathrm{I},{ }^{125} \mathrm{Sb},{ }^{193} \mathrm{Sn},{ }^{103} \mathrm{Ru}$, and ${ }^{106} \mathrm{Ru}$.

\subsection{Radionuclide Analysis Methods}

A series of methods based on "principles of measurement" are described which are applicable to the analysis of radionuclides collected from airborne effluent streams at stationary sources. These methods are applicable only under the conditions stated and within the limitations described.

Some methods specify that only a single radionuclide be present in the sample or the chemically separated sample. This condition should be interpreted to mean that no other radionuclides are present in quantities which would interfere with the measurement.

Also identified (Table 1 ) are methods for a selected list of radionuclides. The listed radionuclides are those which are most commonly used and which have the greatest potential for causing dose to members of the public. Use of methods based on principles of measurement other than those described in this section must be approved in advance of use by the Administrator. For radionuclides not listed in Table 1, any of the described methods may be used provided the user can demonstrate that the applicability conditions of the method have been met.

The type of method applicable to the analys is of a radionuclide is dependent upon the type of radiation emitted, i.e., alpha, beta or gamma. Therefore, the methods described below are grouped according to principles of measurements for the analysis of alpha, beta and gamma emitting radionuclides.

\subsection{Methods for Alpha Emitting Radionuclides}

\subsubsection{Method A-1, Radiochenistry-Alpha Spectrometry.}

Principle: The element of interest is separated from other elements, and from the sample matrix using radiochemical techniques. The procedure may involve precipitation, ion exchange, or solvent extraction. Carriers (elements chemically similar to the element of interest) may be used. The element is deposited on a planchet in a very thin film by electrodeposition or by coprecipitation on a very small amount of carrier, such as lanthanum fluoride. The deposited element is then counted with an alpha spectrometer. The activity of the nuclide of interest is measured by the number of alpha counts in the appropriate energy region. A correction 
for chemical yield and counting efficiency is made using a standardized radioactive nuclide (tracer) of the same element. If a radioactive tracer is not available for the element of interest, a predetermined chemical yield factor may be used.

Applicability: This method is applicable for determining the activity of any alpha-emitting radionucl ide, regardless of what other radionuclides are present in the sample provided the chemical separation step produces a very thin sample and removes all other radionuclides which could interfere in the spectral region of interest. APHA-605(2), ASTM-D-3972(13).

The method used involves dissolution (LA-549-112), chemical separation (LA-943-123), electrodeposition (LA-542-101), followed by alpha spectrometry (LA-508-051). It meets ail the requirements of the EPA-suggested method. This is used for analyzing ${ }^{241} \mathrm{Am},{ }^{238} \mathrm{Pu}$, and ${ }^{259,240} \mathrm{Pu}$ in the air filter samples. The activities of these nuclides are determined by direct comparison with the recoveries of (National Institute of Standards and Technology ([NIST] traceable) ${ }^{243} \mathrm{Am}$ and ${ }^{236} \mathrm{Pu}$ tracers.

\subsubsection{Method A-2, Radiochemistry-Alpha Counting.}

Principle: The element of interest is separated from other elements, and from the sample matrix using radiochemistry. The procedure may involve precipitation, ion exchange, or solvent extraction. Carriers (elements chemically similar to the element of interest) may be used. The element is deposited on a planchet in a thin film and counted with a alpha counter. A correction for chemical yield (if necessary) is made. The alpha count rate measures the total activity of all emitting radionuclides of the separated element.

Applicability: This method is applicable for the measurement of any alpha-emitting radionuclide, provided no other alpha emitting radionuclide is present in the separated sample. It may also be applicable for determining compliance, when other radionuclides of the separated element are present, provided that the calculated emission rate is assigned to the radionuclide which could be present in the sample that has the highest dose conversion factor. IDO-12096(18).

Because the tracer technique is used in the separation process, this method is not used for air filter analysis.

\subsubsection{Method A-3, Direct Alpha Spectrometry.}

Principle: The sample, collected on a suitable filter, is counted directly on an alpha spectrometer. The sample must be thin enough and collected on the surface of the filter so that any absorption of alpha particle energy in the sample or the filter, which would degrade the spectrum, is minimal.

Applicability: This method is applicable to simple mixtures of alpha emitting radionuclides and only when the amount of particulates collected on the filter paper are relatively small and the alpha spectra is adequately resolved. Resolutions should be $50 \mathrm{keV}$ (FWHM) or better, ASTM-D-3084(16).

The method used follows the procedure L0-150-133, then LA-508-110 for total alpha counts, and finally LA-508-051 for alpha spectrometry. It partially meets the requirements of the EPA method. This method is usually used for emergency air samples. The sample is counted on the alpha counter of known efficiency to obtain the total alpha counts. In the alpha energy analysis (AEA), the relative peak fractions of different alpha emitters identified in the sample are determined. The peak fractions are then used to correct the 
total alpha counts and thus determine the activities of individual alpha nuclides present in the sample.

\subsubsection{Method A-4, Direct Alpha Counting (Gross alpha determination).}

Principle: The sample, collected on a suitable filter, is counted with an alpha counter. The sample must be thin enough so that self-absorption is not significant and the filter must be of such a nature that the particles are retained on the surface.

Applicability: Gross alpha determination may be used to measure emissions of specific radionuclides only (1) when it is known that the sample contains only a single radionuclide, or the identity and isotopic ratio of the radionuclides in the sample are well known, and (2) measurements using either Method A-1, A-2 or A-5 have shown that this method provides a reasonably accurate measurement of the emission rate. Gross alpha measurements are applicable to unidentified mixtures of radionuclides only for the purposes and under the conditions described in section 3.7. APHA-601(3), ASTM-D-1943(10).

The method used follows the procedure LA-508-110 or LA-508-114. It meets all of the requirements stated in the EPA-suggested method.

\subsubsection{Method A-5, Chemical Determination of Uranium.}

Uranium: Uranium may be measured chemically by either colorimetry or fluorometry. In both procedures, the sample is dissolved, the uranium is oxidized to the hexavalent form and extracted into a suitable solvent. Impurities are removed from the solvent layer. For colorimetry, dibenzoylmethane is added, and the uranium is measured by the absorbance in a colorimeter. For fluorometry, a portion of the solution is fused with a sodium fluoride-lithium fluoride flux and the uranium is determined by the ultraviolet activated fluorescence of the fused disk in a fluorometer

Applicability: This method is applicable to the measurements of emission rates of uranium when the isotopic ratio of the uranium radionuclides is well known.

ASTM-E318(15), ASTM-D-2907(14).

Total uranium is determined by procedure LA-925-107. The laser-induced kinetic phosphorescence analyzer is an improvement over the old fluorometric method for uranium determination. It is highly sensitive (lower detection level of $50 \mathrm{ppt}$ is quite possible) because the laser frequency is used specifically for excitation of uranium atoms. It is faster and produces quality numbers. Quality can also be monitored during analysis. It exceeds the requirements mentioned in the EPA method.

\subsubsection{Method A-6, Radon-222-Cont inuous Gas Monitor.}

Principle: Radon-222 is measured directly in a continuously extracted sample stream by passing the air stream through a calibrated scintillation cell. Prior to the scintillation cell, the air stream is treated to remove particulates and excess moisture. The alpha particles from radon-222 and its decay products strike a zinc sulfide coating on the inside of the scintillation cell producing light pulses. The light pulses are detected by a photomultiplier tube which generates electrical pulses. These pulses are processed by the system electronics and the read out is in pCi/l of radon-222.

Applicability: This method is applicable to the measurement of radon-222 in effluent streams which do not contain significant quantities of radon-220. Users of this method should calibrate the monitor in a radon calibration chamber at least twice per year. The background of the monitor should also be checked periodically by operating the instrument in a low radon environment. EPA 520/1-89-009(24).

Not applicable at the 222-S Laboratory. 
WHC-EP-0466-1

\subsubsection{Method A-7, Radon-222"Alpha Track Detectors}

Principle: Radon-222 is measured directly in the effluent stream using alpho track detectors (ATD). The alpha particles emitted by radon-222 and its decay products strike a small plastic strip and produce submicron damage tracks. The plastic strip is placed in a caustic solution that accentuates the damage tracks which are counted using a microscope or automatic counting system. The number of tracks per unit orea is corrected to the radon concentration in air using a conversion factor derived from data generated in a radon calibration facility.

Applicability: Prior approval from EPA is required for use of this method. This method is only applicable to effluent streams which do not contain significant quantities of radon-220, unless special detectors are used to discriminate against radon 220 . This method may be used only when ATDs have been demonstrated to produce data comparable to data obtained with Method A-6. Such data should be submitted to EPA when requesting approval for the use of this method. EPA 520/1-89-009(24).

Not applicable; direct monitoring of ${ }^{222} \mathrm{Rn}$ is not performed at the 222-S Laboratory.

3.2 Methods for Gaseous Beta Emitting Radionuclides.

3.2.1 Method B-1, Direct Counting in Flow-Through Ionization Chambers.

Principle: An ionization chamber containing a specific volume of gas which flows at a given flow rate through the chamber is used. The sample (effluent stream sample) acts as the counting gas for the chamber. The activity of the radionuclide is determined from the current measured in the ionization chamber.

Applicability: This method is applicable for measuring the activity of a gaseous beta emitting radionuclide in an effluent stream that is suitable as a counting gas, when no other beta-emitting nuclides are present. DOE/EP-0096(17), NCRP-58(23).

Not applicable; not performed.

3.2.2 Method B-2, Direct Counting with In-line or off-line Beta Detectors.

Principle: The beta detector is placed directly in the effluent stream (in-line) or an extracted sample of the effluent stream is passed through a chamber containing a beta detector (off-line). The activities of the radionuclides present in the effluent stream are determined from the beta count rate, and a knowledge of the radionuclides present and the relationship of the gross beta count rate and the specific radionuclide concentration.

Applicability: This method is applicable only to radionuclides with maximum beta particle energies greater then $0.2 \mathrm{MeV}$. This method may be used to measure emissions of specific radionuclides only when it is known that the sample contains only a single radionuclide or the identity and isotopic ratio of the radionuclides in the effluent stream are well known. Specific radionuclide analys is of periodic grab samples may be used to identify the types and quantities of radionuclides present and to establish the relationship between specific radionuclide analyses and gross beta count rates.

This method is applicable to unidentified mixtures of gaseous radionuclides only for the purposes and under the conditions described in Section 3.7 .

Not applicable; not performed.

3.3 Methods for Non-Gaseous Beta Emitting Radionuclides.

\subsubsection{Method B-3, Radiochemistry-Beta Counting.}

Principle: The element of interest is separated from other elements, and from the sample matrix by radiochemistry. This may involve precipitation, distillation, ion exchange, or solvent extraction. Carriers (elements chemically similar to the element of interest) may be used. The element is deposited on a planchet, and counted with a beta counter. Corrections for chemical yield and decay (if necessary) are made. The beta count rate determines the total activity of all radionuclides of the separated 
- lement. This method may also involve the radiochemical separation and counting of a daughter element, after a suitable period of ingrowth, in which case it is specific for the parent nuclide.

Apolicability: This method is applicable for measuring the activity of any beta-emitting radionuclide, with a maximum energy greater than $0.2 \mathrm{MeV}$, provided no other radionuclide is present in the separated sample. APHA-608(5).

The method used for determining ${ }^{89} \mathrm{Sr},{ }^{90} \mathrm{Sr} /{ }^{90} \mathrm{Y}$ in air filter samples is carried out using procedures LA-549-112 (dissolution) and LA-220-103 (for chemical separation), followed by procedure LA-508-11l (total beta counting). The laboratory method certainly meets the requirements stated above.

\subsubsection{Method B-4, Direct Beta Counting (Gross beta determination).}

Principle: The sample, collected on a suitable filter, is counted with a beta counter. The sample must be thin enough so that self-absorption corrections can be made.

Applicability: Gross beta measurements are applicable only to radionuclides with maximum beta particle energies greater than $0.2 \mathrm{MeV}$. Gross beta measurements may be used to measure emissions of specific radionuclides only (1) when it is known that the sample contains only a single radionuclide, and (2) measurements made using Method B-3 show reasonable agreement with the gross beta measurement. Gross beta measurements are applicable to mixtures of radionuclides only for the purposes and under the conditions described in section 3.7. APHA-602(4), ASTM-D-1890(11).

For gross beta determination, procedure LA-508-110 or LA-508-114 is followed. It satisfies the method requirements.

3.3.3 Method B-5, Liquid Scintillation Spectrometry.

Principle: An al iquot of a collected sample or the result of some other chemical separation or processing technique is added to a liquid scintillation "cocktail" which is viewed by photomultiplier tubes in a liquid scintillation spectrometer. The spectrometer is adjusted to establish a channel or "window" for the pulse energy appropriate to the nuclide of interest. The activity of the nuclide of interest is measured by the counting rate in the appropriate energy channel. Corrections are made for chemical yield where separations are made.

Applicability: This method is applicable to any beta-emitting nuclide when no other radionuclide is present in the sample or the separated sample provided that it can be incorporated in the scintillation cocktail. This method is also applicable for samples which contain more than one radionuclide but only when the energies of the beta particles are sufficiently separated so that they can be resolved by the spectrometer. This method is most applicable to the measurement of low-energy beta emitters such as tritium and carbon-14. APHA.609(6), EML LV-539-17(19).

This method is used for determining ${ }^{147} \mathrm{Pm}$ in air filter samples (LA-549-112 for dissolution, LA-613-111 for chemical separation, LA-548-11] for incorporating into scintillation cocktail, and LA-508-121 for liquid scintillation counting). This is also used for determination of ${ }^{14} \mathrm{C}$ (LA-348-101, LA-548-111, and LA-508-121, sequentially) and ${ }^{3} H$ (LA-218-112, LA-548-111, and LA-508-121, sequentially) in gas samples. This method satisfies all of the requirements. 


\subsection{Gemma Emitting Radionuclides}

\subsubsection{Method G-1. High Resolution Gamma Spectronetry.}

Principle: The sample is counted with a high resolution gamma detector, usually ither Ge(Li) or a high purity Ge detector, connected to a multichannel analyzer or computer. The gamme emitting radionuclides in the sample are measured from the gamme count rates in the energy regions characteristic of the individual radionuclide. Corrections are made for counts contributed by other radionuclides to the spectral regions of the radionuclides of interest. Radio-chemical separations may be made prior to counting but ore usually not necessary.

Applicability: This method is applicable to the measurement of any gamm emitting radionuclide with gamma energies greater than $20 \mathrm{keV}$. It can be applied to complex mixtures of radionuclides. The samples counted may be in the form of particulate filters, absorbers, liquids or gases. The method may also be applied to the analysis of gaseous gamma emitting radionuclides directly in an effluent strean by passing the stream through a chamber or cell containing the detector. ASTM-3649(9), $100-12096(18)$.

Hanford's method uses gamma ray spectroscopy with high resolution germanium detectors and follows procedure LA-508-052. It meets all the requirements explained in the EPA method.

3.4.2 Method G-2, Low Resolution Gamma Spectrometry.

Principle: The sample is counted with a low resolution gamma detector, a thallium activated sodium iodide crystal. The detector is coupled to a photomultiplier tube and connected to a multichannel analyzer. The gamma emitting radionuclides in the sample are measured from the gamma count rates in the energy regions characteristic of the individual radionuclides. Corrections are made for counts contributed by other radionuclides to the spectral regions of the radionuclides of interest. Radiochemical separation may be used prior to counting to obtain less complex gama spectra if needed.

Applicability: This method is applicable to the measurement of gamma emitting radionuclides with energies greater than $100 \mathrm{keV}$. It can be applied only to relatively simple mixtures of gamma emitting radionuclides. The samples counted may be in the form of particulate filters, absorbers, liquids or gas. The method can be applied to the analysis of gaseous radionuclides directly in an effluent stream by passing the gas stream through a chamber or cell containing the detector. ASTM-D-2459(12), EMSL-LV-0539-17(19).

Not applicable because this method is not used in air filter analysis.

\subsubsection{Method G-3, single Channel Gamma Spectrometry.}

Principle: The sample is counted with a thallium activated sodium iodide crystal. The detector is coupled to a photomultiplier tube connected to a single channel analyzer. The activity of a gamma emitting radionuclide is determined from the gamma counts in the energy range for which the counter is set.

Applicability: This method is applicable to the measurement of a single gamma emitting radionuclide. It is not applicable to mixtures of radionuclides. The samples counted may be in the form of particulate filters, absorbers, liquids or gas. The method can be applied to the analysis of gaseous radionuclides directly in an effluent stream by passing the gas stream through a chamber or cell containing the detector.

Not applicable because this technique is not used in air filter analysis. 
3.4.4 Method G-4, Gross Gemma Counting.

Principle: The sample is counted with a gams detector usually a thallium activated sodium iodine crystal. The detector is coupled to a photomultiplier tube and gamme rays above a specific threshold energy level are counted.

Applicability: Gross gamma measurements may be used to measure emissions of specific radionuclides only when it is known that the sample contains a single radionuclide or the identity and isotopic ratio of the radionuclides in the effluent stream are well known. When gross gamma measurements are used to determine emissions of specific radionuclides periodic measurements using Methods G-1 or G-2 should be made to demonstrate that the gross gamma measurements provide rellable emission data. This method may be applied to analysis of gaseous radionuclides directly in an effluent stream by placing the detector directly in or adjacent to the effluent stream or passing an extracted sample of the effluent stream through a chamber or cell containing the detector.

Not applicable.

3.5 Counting Methods. All of the methods with the exception of Method A-5 involve counting the radiation emitted by the radionuclide. Counting methods applicable to the measurement of alpha, beta and garma radiations are listed below. The equipment needed and the counting principles involved are described in detail in ASTM-3648(8).

\subsubsection{Alpha Counting:}

- Gas Flow Proportional Counters. The alpha particles cause ionization in the counting gas and the resulting electrical pulses are counted. These counters may be windowless or have very thin windows.

- Scintillation Counters. The alpha particles transfer energy to a scintillator resulting in a production of light photons which strike a photomultiplier tube converting the light photons to electrical pulses which are counted. The counters may involve the use of solid scintillation materials such as zinc sulfide or liquid scintillation solutions.

- Solid-State Counters. Semiconductor materials, such as silicon surface-barrier p-n junctions, act as solid ionization chambers. The alpha particles interact which the detector producing electron hole pairs. The charged pair is collected by an applied electrical field and the resulting electrical pulses are counted.

- Alpha spectrometers. Semiconductor detectors used in conjunction with multichannel analyzers for energy discrimination.

Alpha proportional counters (home-built chambers with EG\&G ORTEC electronics), window-type gas flow proportional counters (some having automatic sample changer), surface-barrier scilidstate detectors connected to a multichannel analyzer (MCA) (Series 85, Jupiter system manufactured by Canberra Industries, Inc.) are used for air filter analysis in 222-S Laboratory. The laboratory equipment meets the EPA specifications.

\subsubsection{Beta Counting:}

- Ionization Chambers. These chambers contain the beta-emitting nuclide in gaseous form. The ionization current produced is measured.

- Geiger-Muller (GM) Counters-or Gas Flow Proportional Counters. The beta particles cause ionization in the counting gas and the resulting electrical pulses are counted. Proportional gas flow counters which are 


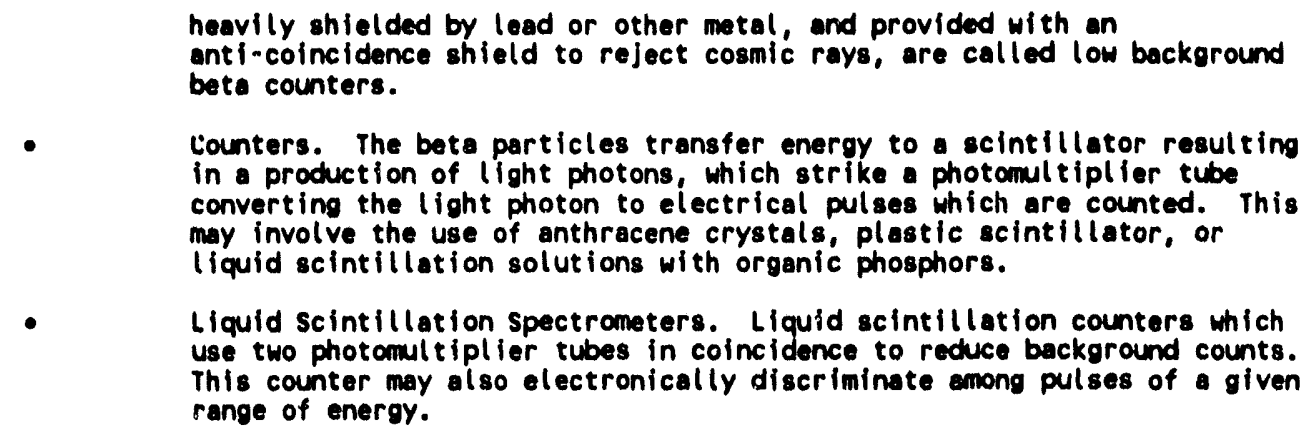

heavily shielded by lead or other metal, and provided with an anti-colncidence shield to reject cosmic rays, are called low background

Window-type gas flow proportional counter (some having an automatic sample changer) liquid scintillation spectrometers manufactured by Beckman Instruments, Inc., are used for analysis. The laboratory counting equipment meets the requirements.

\subsubsection{Gamma Counting:}

- Low-Resolution Gamma Spectrometers. The gama rays interact with thallium activated sodium iodide or cesium iodide crystal resulting in the release of light photons which strike a photomultiplier tube converting the light pulses to electrical pulses proportional to the energy of the gamma ray. Multi-channel analyzers are used to separate and store the pulses according to the energy absorbed in the crystal.

High-Resolution gamma Spectrometerc. Gamma rays interact with a lithium-drifted (Ge(Li)) or high-purity germanium (HPGe) semiconductor detectors resulting in a production of electron-hole pairs. The charged pair is collected by an applied electrical field. A very stable low noise preamplifier amplifies the pulses of electrical charge resulting from the gamma photon interactions. Multichannel analyzers or computers are used to separate and store the pulses according to the energy absorbed in the crystal.

single Channel Analyzers. Thallium activated sodium iodide crystals used with a single window analyzer. Pulses from the photomultiplier tubes are separated in a single predetermined energy range.

High-resolution gamma detectors (high purity Ge detectors for both low and high energies) from EG\&G ORTEC and Princeton Gamma Tech, well-type pure Ge detectors connected to MCA (Canberra's Jupiter system) are available and used for air filter analysis. The laboratory equipment exceeds the EPA requirements.

3.5.4 Calibration of Counters. Counters are calibrated for specific radionuclide measurements using a standard of the radionuclide under either identical or very similar conditions as the sample to be counted. For garma spectrometers a series of standards covering the energy range of interest may be used to construct a calibration curve relating gamm energy to counting efficiency.

In those cases where a standard is not available for a radionuclide, counters may be calibrated using a standard with energy characteristics as similar as possible to the radionuclide to be measured. For gross alpha and beta measurements of the unidentified inixtures of radionuclides, alpha counters are calibrated with a natural uranium standard and beta counters with a cesium-137 standard. The standard must contain the same weight and distribution of solids as the samples, and be mounted in an identical manner. If the samples contain variable amounts of solids, calibration curves relating weight of solids present to counting efficiency are prepared. standards other than those prescribed may be used provided it can be shown that such standards are more applicable to the radionucl ide mixture measured. 
A mixed gamma standard (NIST traceable) emitting various gamma-rays ranging from 59 to $1850 \mathrm{keV}$ is used, using vendorsupplied calibration software, for constructing efficiency versus energy calibration curves for different geometrical configurations used in gamma analysis. The calibration procedure for gamma ray spectrometer is documented in LQ-508-003. The calibration procedure used meets the EPA criteria for gamma ray spectroscopic analysis.

For calibration of beta detectors for ${ }^{90} \mathrm{Sr} /{ }^{90} \mathrm{Y}$ analysis, procedure LQ-508-002 is used in conjunction with LQ-508-005. It meets the requirements of the EPA-suggested method. A method standard also is used to check the performance and calibration of the detector.

For calibration of alpha/beta proportional counters, the procedure LQ-508-002 is carried out. It partially deviates from the EPA requirements. For gross alpha and gross beta measurements, our instruments are calibrated with ${ }^{241} \mathrm{Am}$ and ${ }^{60} \mathrm{Co}$ standards, respectively. The reasons for choosing the ${ }^{241} \mathrm{Am}$ standard for alpha calibration are as follows:

- It is commonly found in the main stack air samples.

- Alpha counting efficiency usually is the same for other alpha emitters that also are found in the air stack samples

- The ${ }^{241} \mathrm{Am}$ standard also can be checked independently by gamma analysis.

The reason for using the ${ }^{60} \mathrm{Co}$ standard for beta calibration is the lower counting efficiency with ${ }^{60} \mathrm{Co}$ (beta $\max =317 \mathrm{keV}$ ) compared to those with ${ }^{137} \mathrm{Cs}$ (beta $\max =511 \mathrm{keV}$ ) and ${ }^{90} \mathrm{Sr}$ (beta $\max =546 \mathrm{keV}$ ). Consequently, it will generate conservative numbers in our analysis.

The calibration curves relating weight of solids present to counting efficiencies are not done in alpha/beta analysis, but currentiy are being evaluated.

3.6 Radiochemical Methods for Selected Radionuclides. Methods for a selected list of radionuclides are listed in Table 1 . The radionuclides listed are those which are most commonly used and which hove the greatest potential for causing doses to members of the public. For radionuclides not listed in Table 1, methods based on any of the applicable "principles of measurement" described in section 3.1 through 3.4 may be used.

The air samples from the main stacks are well characterized, Some of the radionuclides ident ified ${ }^{241} \mathrm{Am},{ }^{238} \mathrm{Pu},{ }^{239,240} \mathrm{Pu},{ }^{90} \mathrm{Sr},{ }^{134} \mathrm{Cs}$, ${ }^{137} \mathrm{Cs},{ }^{144} \mathrm{Ce},{ }^{4{ }^{7}} \mathrm{Pm},{ }^{14} \mathrm{C},{ }^{3} \mathrm{H}$, and $\left.{ }^{13} \mathrm{I}\right)$ are listed in Table 1 of Method 114 (EPA 1991a) and are analyzed according to the approved methods given in the table. 0ther radionuclides $\left({ }^{95} \mathrm{Nb},{ }^{95} \mathrm{Zr}\right.$, ${ }^{129} \mathrm{I}$, ${ }^{106} \mathrm{Rh} /{ }^{106} \mathrm{Ru},{ }^{113} \mathrm{Sn},{ }^{125} \mathrm{Sb}$, and ${ }^{103} \mathrm{Ru}$ ) not listed in the table are analyzed by the methods outlined in Method 114, depending on the 
type of emitted radiations. It is important to note here that the nuclides ${ }^{95} \mathrm{Zr},{ }^{95} \mathrm{Nb}$, and ${ }^{103} \mathrm{Ru}$ have nearly decayed to nondetectable levels because no product is being produced.

3.7 Applicability of Gross Alpha and Beta Measurements to Unidentified Mixtures of Radionuclides. Gross alpha and beta measurements may be used as a screening measurement as a part of an emission measurement program to identify the need to do specific radionuclide analyses or to confirm or verify that unexpected radionuclides are not being released in significant quantities.

Gross alphe (Method A-4) or gross heta (Methods B-2 or B-4) measurements may also be used for the purpose of comparing the measured concentrations in the effluent stream with the limiting "Concentration Levels for Environmental Compl iance" in Table 2 of Appendix $E$. For unidentified mixtures, the measured concentration value shall be compared with the lowest environmental concentration limit for any radionuclide which is not known to be absent from the effluent stream.

This is not applicable because the air effluents from the Hanford Site main stacks are well characterized. However, gross alpha and beta analyses for weekly and daily air samples are routinely performed in the 222-S Laboratory before starting specific radionuclide analyses. Following this practice, the facility can verify a significant release of a radionuclide into the air so corrective actions to minimize radionuclide emission into the environment can be taken promptly by facility personnel. The gross alpha and beta results from analysis are compared to those listed in the appendix of DOE Order 5400.5 (DOE 1990b) for compliance.

\subsection{Quality Assurance Methods}

WHC-EP-0536, Quality Assurance Program Plan for Radionuclide Airborne Emissions Monitoring (WHC 1991h), was prepared to address many of the requirements of Method 114. The Environmental Protection (EP) group prepared a future quality assurance project plan (QAPjP) for the facility.

Each facility required to measure their radionuclide emissions shall conduct a quality assurance program in conjunction with the radionuclide emission measurements. This program shall assure that the emission measurements are representative, and are of known precision and accuracy and shall include administrative controls to assure prompt response when emission measurements indicate unexpectedly large emissions. The program shall consist of a system of policies, organizational responsibilities, written procedures, data quality specifications, audits, corrective actions and reports. This quality assurance program shall include the following program el ements:

4.1 The organizational structure functional responsibilities, levels of authority and lines of communications for all activities related to the emissions measurement program shall be identified and documented.

See Section 6.2 of WHC-EP-0536 (WHC 1991h) for the organizational structure.

4.2 Adninistrative controls shall be prescribed to ensure prompt response in the event that emission levels increase due to unplanned operations.

WHC-CM-4-12 (WHC 1992d), Section 1.14, REV 0, "Alarm Response and Management." Provides guidance and sets requirements for managing the responses to alarms that are the responsibility of Occupational Health and Safety (OHS). This practice is applicable to all members of OHS. Area OHS managers shall ensure that all members of their organizations are aware of and adhere to this practice. 
WHC-CM-4-12, Section 2.1, REV 0, "Radiological Problem Reporting Program." The radiological problem reporting program provides a documented record of observed radiological problems, a mechanism for reporting these problems to management for action, a capability to track and monitor the progress of the planned corrective actions, and a database for assessing trends in radiological program performance and needed actions.

WHC-CM-4-12, Section 12.1, REV 1, "Emergency Response." An emergency is a sudden, unexpected event requiring immediate response to mitigate impacts to people, property, or the environment. When radioactive material is involved, Health Physics (HP) plays a major role in evaluating, controlling, and recovering from the event. To perform this function, HP personnel receive training to respond to a variety of emergency situations. The HP procedures are written to provide guidelines to respond to emergencies. Together, the training and the written procedure detail the HP Emergency Response Program.

Emergency Response. The HP personnel are, in many situations, the first to respond to a radiological emergency. The ability to assess and evaluate the situation and take immediate steps to minimize the effects of the event is crucial for controlling the emergency. The HP personnel must use their training and experience to make good decisions during the initial response to an emergency.

An emergency response may be initiated by personnel observing the event, alarms, the Patrol Operation Center or the Emergency Control Center(s) once they are manned. For a planned response, HP personnel shall be in teams of at least two. Out of necessity (e.g., backshift response), one member could be an Operations person, or other emergency service person such as fire or patrol. A rapid response is required; however, no undue risks should be taken nor should employee personnel safety be compromised. The type of emergency determines the level of planning for HP response. For example, a continuous air monitor (CAM) alarm or a small radioactive spill requires little planning for the initial response. However, when an emergency causes a facility evacuation, preplanning (e.g., stay time, entry route, etc.) and approval of the Building/Facility Emergency Director is necessary for a re-entry.

Although HP personnel respond to an emergency using basic guidelines, an area/facility may have specific procedures that have priority over these guidelines.

WHC-IP-0692 (WHC 1992g), Section 12.1.2.3, REV 2, "Effluent Exhaust CAM Alarm Response." This procedure estabi ishes the standard method of handling samples from, and response to alarms at, effluent exhaust 
WHC-EP-0466-1

$\mathrm{CAM}^{*}$ systems. This procedure describes the steps and material necessary to exchange, perform fielo concentration calculations, and submit suspect samples for "rush" or "red envelope" analysis when responding to alarms on effluent exhaust CAM systems.

WHC-IP-0692, Section 12.1.6, REV 1, "Stack Effluent Release Response." This procedure establishes guidelines for responding to a potential or actual release of radioactive material through exhaust stacks. The procedure describes the immediate actions to respond to an exhaust CAM stack alarm (i.e., CAM monitoring downstream or upstream of the final filtration).

WHC-IP-0692, Prociedure No. 12.2.1, REV 2, "Emergency Response Air Sampling." This procedure establishes the instruction and guidelines for air sampling in an emergency situation. The procedure describes the steps for sampling air both inside and outside facilities when a release of radioactive material is suspected.

WHC-IP-0692, Section 12.2.3, REV 0, "Health Physics Emergency Response Team." This procedure provides the organizational structure, responsibilities, and steps for an initial emergency response for the HP Emergency Response Team (ERT) and the HP Technician (HPT) Field Survisy Teams. The HP ERT and the HPT Field Survey Teams may be requested to resoond to an emergency when it is deemed that an environmental reiease of radioactive material may extend beyond the control of a facility or outside the roundaries of the Hanford Site. These teams will have monitoring responsibilities only outside the boundaries of the event site.

WHC-IP-0692, Section 12.2.4, REV 2, "Emergency Radioactive PIume Tracking." This procedure establishes the instructions to track a plume created from a radioactive material release to the environment. This procedure describes the steps to track and determine if a radioactive beta-gamma plume is at ground level or at an elevated level.

Notifications and reporting of specific events related to environmental releases and events involving effluents or hazardous materials are reporte. via instruction given in WHC-CM-5-7, Tank Farms, Grout, and Solid Waste Management Administration Manual, Section 1.22, "Tank Farms Occurrence Reporting and Processing of Operations Information." This procedure establishes and implements specific criteria and requirements for the identification, categorization, notification, and reporting of occurrences at the tank farms, as required by WHC-CM-1-3, MRP 5.14, "Occurrence Reporting and Processing of Operational Information."

\footnotetext{
"The CAM serves as a warning device to alert personnel to releases that exceed normal operating parameters. A CAM collects particulates on a filter monitored continuously by a radiation detector. The CAM filter may be used as a backup for the record sample.
} 
4.3 The sample collection and analysis procedures used in measuring the emissions shall be described including where applicable:

4.3.1 Identification of sampling sites and number of sampling points, including the rationale for site selections.

See response under Method 1, Section 2.1: Selection of Measurement Site and under ANSI N13.1-1969, Appendix A, Section A3.2.

4.3.2 A description of sampling probes ant representativeness of the samples.

See response under ANSI N13.1-1969, Appendix A, Sections A3.1 and A3.2.

\footnotetext{
4.3.3 A description of any continuous monitoring systems used to measure emissions, including the sensitivity of the system, calibration procedures and frequency of calibration.
}

Not applicable; emissions are not monitored continuously.

4.3.4 A description of the sample collection systems for each radionuclide measured, including frequency if collection, calibration procedures and frequency of calibration.

See response in Sections 14.1.2.4 and 14.1.2.6 of this Chapter.

4.3.5 A description of the laboratory analysis procedures used for each radionuclide measured, including frequency of analys is calibration procedures and frequency of calibration.

- Total alplia/total beta activity is determined by procedure LA-508-110 or LA-508-114 on weekly samples, and occasionally on daily air samples, per collection point. The calibration procedure is documented in LQ-508-002. It is done only when deemed necessary by a responsible scientist. The counting system is recalibrated only in case of (1) major repairs or adjustments to the power supply or detector or (2) calibration shift as indicated by the instrument control standards. The performance of the counting systems is checked by running the instrument control standards $\left({ }^{147} \mathrm{Pm}\right.$ for low-energy beta , ${ }^{80} \mathrm{Co}$ for mid-energy beta, ${ }^{37} \mathrm{Cs}$ for high-energy beta, and ${ }^{241} \mathrm{Am}$ for alpha activity) separately. When a batch of air filter samples is run, all the performance standards and the background (for counting frequency refer to L0-150-115) al so are run with it. To verify that the counting system is working properly, the standard values from analys is should fall within the administrative limits set according to appropriate quality assurance program plans (QAPP).

- The laboratory method used for analysis of alpha emitters $\left({ }^{241} \mathrm{Am},{ }^{238} \mathrm{Pu}\right.$, and ${ }^{239}, 240 \mathrm{Pu}$ ) involves various steps (LA-549-112 for dissolution, LA-943-123 for chemical separation, LA-542-10). for electrodeposition, and LA-508-051 for final alpha spectrometry). The analys is of alpha emitters is done on a quarterly composite of weekly/daily air filter samples. The energy resolution and calibration of the AEA system over the energy range of 4 to $6 \mathrm{MeV}$ are checked once a month by the preventive maintenance (PM) procedure 2S18006. Efficiency 
calibration of the AEA is not needed in our analysis method because direct comparison of the sample with recoveries of the tracers $\left({ }^{243} \mathrm{Am}\right.$ and $\left.{ }^{236} \mathrm{Pu}\right)$ is made to determine the activities of the radionuclides present in the sample. To carry out the sample analysis, AEA system performance is checked once every 24 hours for alpha energy shift with a certified mixed alpha source standard. Each alpha energy peak identified in the standard must fall within administratively assigned certain channels $(+10)$ on the MCA. For counting frequency of performance check standards, procedure L0-150-115 is referred to. The recovery of the radionuclides and the calibration of the system are checked on a batch basis by running a method standard under the identical conditions as the sample.

- The laboratory method used for determining beta activity $\left({ }^{89} \mathrm{Sr},{ }^{90} \mathrm{Sr} /{ }^{90} \mathrm{Y}\right)$ consists of a dissolution step (LA-549-112), chemical separation (LA-220-103), and total beta counting (LA-508-111). Analysis is done on a quarterly composite of weekly/daily air filter samples per collection point. The calibration procedure LQ-508-002 (for window-type gas flow proportional counter) is used in conjunction with LQ-508-005 (for mother/daughter case, i.e., ${ }^{90} \mathrm{Sr} /{ }^{90} \mathrm{Y}$ in growth calibration). It is performed only when the responsible scientist finds it necessary. The reasons are the same as stated for total alpha/total beta. The performance of the counting system is checked once per shift by running instrument control standards $\left({ }^{60} \mathrm{Co},{ }^{137} \mathrm{Cs}\right.$, and ${ }^{147} \mathrm{Pm}$ for beta activity). The complete procedure for the ${ }^{90} \mathrm{Sr} /{ }^{90} \mathrm{Y}$ analysis in the sample is carried out with a method standard (several filter papers spiked with ${ }^{90} \mathrm{Sr},{ }^{147} \mathrm{Pm},{ }^{60} \mathrm{Co},{ }^{241} \mathrm{Am},{ }^{239} \mathrm{Pu}$, and $\left.U\right)$ provided by the 222-SA Standard Laboratory) on a batch basis. This checks the overall performance of our method. The chemical yield is determined by using appropriate carrier.

- Determination of beta activity $\left({ }^{147} \mathrm{Pm},{ }^{14} \mathrm{C}\right.$, and $\left.{ }^{3} \mathrm{H}\right)$ involves processing (LA-549-112 and $L A-613-111$ for ${ }^{147} \mathrm{Pm}, L A-348-101$ for ${ }^{14} \mathrm{C}$, and $\left(A-218-112\right.$ for $\left.{ }^{3} \mathrm{H}\right)$, mounting in scintillation cocktail (LA-508-111), and finally, liquid scintillation counting (LA-508-121). The ${ }^{147} \mathrm{Pm}$ analys is is done on quarterly composites of weekly/daily air filter samples. The ${ }^{14} \mathrm{C}$ and ${ }^{3} \mathrm{H}$ analyses are done on biweekly gas samples. For calibration, the quality assurance (QA) section of procedure LA-508-121 is referenced. The calibration of the instrument is checked by the manufacturer's supplied sources $\left({ }^{14} \mathrm{C}\right.$ and $\left.{ }^{3} \mathrm{H}\right)$ and its software.

For ${ }^{147} \mathrm{Pm}$ analysis, the method standard is run once per quarter. The method standard is always run with a batch of samples for ${ }^{3} \mathrm{H}$ and ${ }^{14} \mathrm{C}$ analysis. The results of the method standard checks the overall performance, including the calibration of the counting system. The instrument calibration check is done a minimum of once a week (refer to L0-150-115). 
- For analysis of gamma emitters ${ }^{95} \mathrm{Nb},{ }^{95} \mathrm{Zr},{ }^{134} \mathrm{Cs},{ }^{137} \mathrm{Cs}$, and ${ }^{144} \mathrm{Ce}$ the procedure LA-508-052 is followed. Analys is is done on quarterly composites of weekly/ daily air filter samples. For analys is of volatile radionuclides $\left({ }^{129} \mathrm{I},{ }^{131} \mathrm{I},{ }^{106} \mathrm{Rh} /{ }^{106} \mathrm{Ru},{ }^{113} \mathrm{Sn}\right.$, ${ }^{25 b}$, and ${ }^{103} \mathrm{Ru}$ ) collected weekly on silver zeolite cartridge, the procedure $L A-288-101$ is used in conjunction with procedure LA-508- 052. Calibration of the gamma ray spectrometer is done with the procedure documented in LQ-508-003 using a (NIST traceable) certified mixed gamma ray standard. It is carried out only when it is deemed necessary by a responsible scientist. To check efficiency and energy calibration daily, the performance of each detector of the GEA system over the whole energy range is done once every shift by running a mixed gamma standard consisting of ${ }^{241} \mathrm{Am}$ for low energy, ${ }^{137} \mathrm{Cs}$ for mid energy, and ${ }^{60} \mathrm{Co}_{0}$ for high energy. The results of each of these radionuclides should fall within the administrative limits set according to the appropriate QAPP to continue analys is of samples. The daily performance results are documented. Minor adjustments of the electronics (i.e., fine gain, pole zero of the amplifiers, lower level discriminator of analog-to-digital converter, etc.) are done from time to time when necessary for proper energy calibration. Whenever a minor electronic adjustment is done on a detector, it is followed by analysis of a performance standard. For a major shift in the calibration, the system is then thoroughly calibrated using LQ-508-003.

- The content of the 222-S Laboratory's procedures, test plans, supporting documents, and drawings provide a sufficient level of detail to allow trained personnel to produce quality results safely. Laboratory procedures are controlled as required by WHCCM-5-4, Section 5.4, "Analytical Laboratory Procedures." The specific content of laboratory procedures is defined by its author, based on accepted methods such as 40 CFR 61, Appendix $B$, Method 114 (EPA 1991a). The content must be agreed to by the peer and technical reviewers. While authors are responsible for the specific content of their procedures, they address the topics below.

Summary - MANDATORY - A short description or abstract of the procedure containing enough information to distinguish it from other procedures.

Applications - MANDATORY - Defines the scope and purpose of the specific procedure. This section may be combined with the following element under the title "Applications and Limitations."

Limitations - MANDATORY - Briefly describes those areas in which the procedure is not applicable. A statement of accuracy and precision will be given where appropriate.

Quality Control Protocol - Procedures used to support environmental projects that have specific quality control requirements. For these procedures, the source of the quality control requirements 
will be identified. The samples or project that this element applies to will be identified. The following information is typical of quality control requirements: frequency and type of calibration, reagent blank analysis, spike sample analysis, and duplicate sample analysis.

Impact Level Identifier - MANDATORY - An impact level will be identified for each procedure following WHC-CM-1-3, MRP 5.43, with a brief basis of determination statement. This MRP lists several descriptive paragraphs delineating what constitutes an Impact Level $1,2,3$, or 4 activity. The following parts of MRP 5.43 cover most analytical laboratory procedures.

1. Section 5, Paragraph 6, Part c., Impact Level 3 - work authorization documentation associated with work involving occupational hazards not covered by approved procedure, such as operational safety assessments, radiation work permits, or industrial safety standards.

2. Section 5, Paragraph 6, Part c., Impact Level 4 Documentation for any activity not classed as Impact Level 1 , 2 , or 3 .

The laboratories' procedures are usually specific to one activity. These activities are well defined using common scientific instrumentation and equipment operated in an acceptable manner. The chemicals and materials used are normally small quantities with limited potential for environmental or personnel safety impact. In general, the equipment used in the laboratory is not classified as Safety Class 3 or higher.

Safety - MANDATORY - The procedure must identify applicable safety hazards.

The following documents identify Westinghouse Hanford safety requirements:

- WHC-CM-4-3, Volume 1-3, Industrial Safety

- WHC-CM-4-10, Radiation Protection

- WHC-CM-4-15, Radiation Work Requirements and, Work Permits Manua 7

- WHC-CM-4-29, Nuclear Criticality Safety.

Supporting document WHC-SD-CP-LB-003, Safety in the Analytical Laboratory, is the laboratory general safety document. The authors must review safety requirements and include safety warnings appropriate to the actions directed by the procedure.

Reagents - If the procedure requires analytical reagents, a list of reagents will be provided. The MSDS number will be placed in brackets by each chemical name. Reagent makeup, storage container requirements, unique storage needs, shelf-life requirements, special labeling, and special preparation steps will be included. 
Special notations for any known or suspected carcinogen as listed on WHC-CM-4-3, Volume 2, Table 1, "WHC Master Carcinogen List," will be made on the reagent list.

Reagent preparation described fully in other current Westinghouse Hanford documentation may be included by reference.

Equipment - Special equipment needs will be listed. Standard hood or glovebox equipment is assumed to be available at the work station and does not need to be listed. The fabrication of offstandard equipment will be referenced or described in this section.

Procedure Steps - MANDATORY - A step-by-step description of operations necessary to perform the task will be presented in a logical and sequentially numbered order or an assignment of responsibilities. CAUTIONS and WARNINGS notations will be included for the applicable safety hazard before the action is described. Steps with potential for criticality specification violation will be identified. Explanatory "Notes" may be included for clarification of the process.

Calculations - Calculations required to complete the work will be described in this section. Examples with sample values may be included. All combined factors will be fully described and units noted.

Calibrations - When calibrations are required, a description of how to carry out required calibrations will be given.

Discussion - A discussion of the theoretical aspects of the procedure. Brief identification of unique characteristics and interfaces to aid in troubleshooting may be included.

References - A reference list of published information to provide technical basis for the procedure may be included.

The mandatory topics are addressed in both procedures. However, the laboratories have technical, analytical, and administrative procedures. Non-mandatory topics are included if appropriate to the activity covered by the procedure.

The calibrations of all laboratory instruments are controlled by he Laboratory Instrument Calibration Control System (LICCS)

(WHC-CM-5-4, Section 8.2). The LICCS documents the requirements for and the performance of calibration activities for each analytical instrument or measurement device.

4.3.6 A description of the sample flow rate measurement systems or procedures, including calibration procedures and frequency of calibration.

A sampler probe draws air from the vessel vent stack at a flow rate of $2.93 \mathrm{~L} / \mathrm{sec}\left(6.2 \mathrm{std} \mathrm{ft}^{3} / \mathrm{min}[\mathrm{scfm}]\right)$. The sampler probe incorporates the use of two nozzles for sampling the stack flow (reference drawing $\mathrm{H}-2-69316$, Instrumentation Arrangement 
Elevations and Details, Instrumentation Arrangement Elevations and Details [AEC 1974]). A sample transport line extends from the probe connection flange to the monitoring instruments located on shelves near the stack. The sample transport line is heat traced (operating at $43{ }^{\circ} \mathrm{C}\left[110^{\circ} \mathrm{F}\right]$ ) to inhibit condensation of moisture and resultant sample flow retardation by maintaining the temperature above the dew point. The sample transport line was selected and installed in a manner designed to minimize particle loss attributed to gravity settling, turbulent impaction, and electrostatic effects. The run lengths, bend radii, and tube transition severity of the sample transport line are minimized to the extent practical. The bend radii are at least 10 times the inside diameter of the transport line. The sample air flows into the vessel vent radiation monitoring system instrumentation rack. Within the rack, the sample stream passes through a flow splitter and is divided into two parts.

1. One part passes through a record sample filter. The record sampler collects effluent particulates on a 47-mm-diameter filter. They are exchanged weekly and evaluated for gross alpha and beta activities by laboratory analysis. The record sampler provides an indication of the amount and concentrations of radioactive particulates being discharged. The record samples provide the basis for reporting the amount and concentration of radionuclides released to the environment. These reports are forwarded to all appropriate organizations and agencies.

From there, the record sample loop passes through two silver zeolite cartridge filters. These filters collect volatile radionuclides. Silver zeolite filters are designed to collect ${ }^{129} \mathrm{I},{ }^{131} \mathrm{I},{ }^{125} \mathrm{Sb},{ }^{113} \mathrm{Sn},{ }^{103} \mathrm{Ru}$, and ${ }^{106} \mathrm{Ru}$. The cartridge filters are exchanged and sent to the laboratory weekly.

Downstream of the filters the record sample loop passes in turn through a flow meter, a flow integrator indicator (totalizer), a pressure indicator, a flow regulator, and a vacuum return pump. The record sampling system has sample flowrate indicating (local and remote) and totalizing $(2.2 \mathrm{scfm} \pm 10 \%)$ capabilities. The flow rate regulator is provided to maintain a constant flow rate through the collection filter assembly to compensate for filter loading effects. Audible and yisible alarm signals indicating low sample flow ( $\leq 1.25 \mathrm{ft}^{3} / \mathrm{min}[\mathrm{cfm}]$ ) are provided locally (bell and beacon) and remotely on the monitor and control system (MCS) in the 242-A control room. The record sample flow rate $(2.2 \mathrm{scfm} \pm 5 \%)$ is sized to provide optimum samples for laboratory analysis.

2. The second part of the sample stream is divided into two more streams by another flow splitter. 
a. One portion passes through a beta-gamma CAM equipped with remote (control room) and local alarms. The CAM (RM-VV-2) continuously monitors particulate matter buildup on a 47-mm-diameter filter paper for the detection and measurement of beta and gamma radiation. The filter paper is collected weekly and analyzed for gross beta and gamma readings.

b. The second portion passes through an alpha CAM, which is similar to the beta-gamma CAM. It is equipped with remote (control room) and local alarms. This CAM (RM VV-1) continuously monitors for alpha radionuclide buildup on 47-mm-diameter sample filter papers. Filter papers are collected weekly and analyzed for gross alpha concentration.

The CAM loops (beta/gamma and alpha) within the 296-A-22 stack effluent monitoring system have flow rate indicating and regulating capabilities. A flow rate regulator is provided on each loop to maintain a constant flow rate through the collection filter assembly to compensate for filter loading effects. The CAM systems have local readout count-rate meters and remote recording capability in the control room (on the MCS). Audible and visible al arms, including high airborne radiation, instrument malfunction, and low sample flow indications, are provided locally and on the MCS in the 242-A control room. In addition, high stack radiation and high stack alpha radiation alarms are annunciated on the computer automated surveillance system (CASS). An exhaust alpha monitor failure alarm is also tied to the CASS. An elapsed time meter is interlocked with the stack blower fan operation to provide a measure of exhaust stack operation times. The record sample vacuum pump is ganged to exhaust fan operation via a switched receptacle in the system cabinet. The CAM vacuum pumps operate continuously via the unswitched receptacle in the cabinet.

Independent vacuum pumps are provided for each loop of the system. Redundant vacuum systems are not furnished, but failure annunciation (low flow rates) is provided and checked periodically to demonstrate operability.

Each loop of the sample stream, after passing through its particular sampler/monitor, and flow control system is pumped by individual vacuum pumps through a line that discharges back into the vessel vent stack.

The record sample holder is described as follows:

- Large outside diameter with knurled outer ring for ease of opening

- Rubber "0" ring gaskets used to seal the sample holder

- $\quad$ Fine mesh screen behind the sample filter to keep the sample a constant distance from the inlet 
- Sample vacuum side is connected by a flexible line for ease of access.

The record sample vacuum system consists of the equipment described below.

- Rotameter: Reads out in std $\mathrm{ft}^{3}$ /hour (SCFH) or cfm of air flow through the sample paper. Certified accurate to $\pm 10 \%$ at $2.2 \mathrm{scfm}$. Operating range: 0.0 to $3.0 \mathrm{scfm} \pm 5 \%$.

- Gas meter totalizer: Industry standard gas meter. Reads out in cubic meters. Measures the total volume of air pulled through the sample filter. Certified accurate to $\pm 5 \%$ at $2.2 \mathrm{scfm}$.

- Flow alarm switch: Trips an alarm at the loss of flow (at $1.25 \mathrm{cfm}$ ) due to vacuum pump failure and/or sample filter clogging. Accurate to within $\pm 10 \%$.

- Vacuum line to the vacuum pump: Equipped with a standard quick disconnect for connection to alternative pumps and for sample filter retrieval.

- Stack flow switch: Controls a "switched" power outlet providing power to the record sample vacuum pump.

Automatically shuts down the record sample vacuum when the stack fans cease operation.

- Record sample timer: Provides integrated timing of power supplied to the "switched" power outlet. Resettable 5-digit timer to 99999 . Normally reset to zero when the record sample is exchanged. Certified accurate to $\pm 1 \%$.

Calibration and inspection of the system are accomplished using the following schedule:

\begin{tabular}{ll} 
Procedure & Frequency \\
\hline PROC 5.2.2.6 & Week1y \\
PSCP-3-002 & Month1y \\
PSCP-3-003 & Monthly \\
PSCP-4-007 & 6 Months \\
PSCP-4-091 & 6 Months \\
PSCP-6-029 & 6 Months \\
PSCP-7-001 & 6 Months
\end{tabular}

The titles of these procedures are as follows:

- $\quad$ Gaseous Effluent Sampling and Monitoring System Operability Inspection," Health Physics Procedure 5.2.2.6, REV 2 
- Maintenance Engineering Services Calibration Procedure, "Eberline Beta Air Monitor, Models AMS-3, AMS-3A, And 700300," Calibration Procedure PSCP-3-002

- Maintenance Engineering Services Calibration Procedure, "Eberline Alpha-4, -5, and 5A," Calibration Procedure PSCP-3-003

- Maintenance Engineering Services Calibration Procedure, "Rockwell Type Gas Meter," Calibration Procedure PSCP-4-007

- Maintenance Engineering Services Calibration Procedure, "Pressure and Vacuum Gauges," Calibration Procedure PSCP-4-091

- Maintenance Engineering Services Calibration Procedure, "Chem-Tec Adjustable Floiv Switch Model 500," Calibration Procedure PSCP-6-029

- Maintenance Engineering Services Calibration Procedure, "Air Rotameter," Calibration Procedure PSCP-7-001.

4.3.7 A description of the effluent flow rate measurement procedures, including frequency of measurements, calibration procedures and frequency of calibration.

For the vessel vent, flow measurements are accomplished quarterly via Procedure 7-GN-56. The port available for use is located on the fourth floor of the condenser room, $1 \mathrm{ft}$ above the sampler probe. This location is 44 in. below the flow disturbance presented by the elbow that directs the flow outside the building. In equivalent stack diameters, these distances place this location at 1.5 downstream and 5.5 upstream.

4.4 The objectives of the quality assurance program shall be documented and shall state the required precision, accuracy and completeness of the emission measurement data including a description of the procedures used to assess these parameters. Accuracy is the degree of agreement of a measurement with a true or known value. Precision is a measure of the agreement among individual measurements of the same parameters under similar conditions. Completeness is a measure of the amount of data obtained compared to the amount expected under normal conditions.

The accuracy of analyses is checked using percent recovery. The evaluation of blind or known check standards provides the percent recovery.

For both blind and known check standards, percent recovery is calculated by the following equation:

$$
P=100 \cdot \frac{R}{S_{t}}
$$

Where:

$P=$ Percent recovery

$\mathrm{R}=$ Measured or recovered analyte concentration in the check standard 
$S_{t}=$ Concentration of analyte in the check standard.

The laboratories do not use manual W. A. Shewhart control charts (Shewhart 1931). The Laboratory Measurement Control System (LMCS) is a software package designed for support of management quality control decisions. Each analytical measurement system has different control parameter requirements based on the use of specific standards. The LMCS program provide a performance versus limits control chart for each standard. The average percent recovery (P) or 100\%, depending on the method, marks the center of the limit. The upper and lower boundaries of the limits are multiples of the standard deviation $(\sigma)$ of the average percent recovery. The laboratory manager approves the LMCS 1 imits, defined as $P \pm n \sigma$, where $n$ is a positive number. The values for $P$ and $\sigma$ are performance based. In generaT, management sets the warning limits at $2 \sigma$ and the control limits at $3 \sigma$ or their equivalent.

When the LMCS identifies an out-of-control method, it automatically initiates corrective action. The system issues an off-standard condition report (OSCR). The scientist in charge of the method must discover and resolve the problem to close out the OSCR. Until the OSCR has been cleared, personnel cannot perform any analyses by this method. After the scientist has resolved the problem, personnel evaluate all analyses performed since the last in-control point.

The laboratories assess precision by examining the results from split samples or laboratory duplicates. Percent relative difference measures the precision of analyses. Percent relative difference is computed by the following equation:

$$
R D=100 \cdot \frac{S_{d}}{X}
$$

Where:

$\mathrm{RD}=\quad$ Percent relative difference

$S_{f}=\quad$ The standard deviation estimate of the duplicate data set

The arithmetic mean (average) of the duplicate data set.

The initial QA objective for completeness of analyses in the laboratories is $90 \%$. This means that the goal is to produce usable analytical data for a minimum of $90 \%$ of the analyses requested on all samples submitted to the laboratory. The laboratory evaluates actual performance against the $90 \%$ objective. If the laboratory performance drops below this limit, management initiates corrective action. This action shall identify and correct those activities within the laboratory that have caused the drop in performance. The objectives are documented in the Quality Assurance Project Plan for Radioactive Airborne Emissions Data Compilation and Reporting, WHC-EP-0528 (WHC 1992m). 
4.5 A quality control progrem shall be established to evaluate and track the quality of the emissions measurement data against preset criteria. The progran should include where applicable system of replicates, spiked semples, split samples, blanks and control charts. The number and frequency of such quality control checks shall be identified.

The samples analyzed under this program consist of mounts made from preparation of stack filters. Each sample collection point produces only one sample, which is sent to the laboratory for analysis. No replicate samples are available. Repeat measurement of individual samples are made at the discretion of the scientist in charge.

As a type of process control sample, stack filters are not subject to matrix effects and radionuclide spikes are not ysed. However, tracer elements ${ }^{243} \mathrm{Am}$ and ${ }^{236} \mathrm{Pu}$ support the analys is of ${ }^{241} \mathrm{Am},{ }^{238} \mathrm{Pu}$, and ${ }^{239}, 240 \mathrm{Pu}$ in the quarterly composite of weekly filter samples.

The laboratory does not split samples. There is no guarantee that the distribution of material on the filter will be homogenous. Because of this, no subsampling procedure, such as splitting, can be assured of producing two representative portions. Also, splitting the sample in effect dilutes the sample, which would adversely effects the method detection limits.

Formal blanks are not available for these analysis. However, before a batch of samples is analyzed, the background of the counting instrument is checked. This background check as made on each planchet and planchet holder.

Control charts and standards used in support of these analyses are described in Section 4.4 .

4.6 A sample tracking system shall be established to provide for positive identification of samples and data through all phases of the sample collection, analysis and reporting system. Sample handling and preservation procedures shall be established to maintain the integrity of samples during collection, storage and analysis.

\section{Refer to Section 9.2 of this FEMP.}

4.7 Periodic internal and external audits shall be performed to monitor compliance with the quality assurance program. These audits shall be performed in accordance with written procedures and conducted by personnel who do not have responsibility for performing any of the operations being audited.

Refer to Section 7.0 of WHC-EP-0536.

4.8 A corrective action program shall be established including criteria for when corrective action is needed, what corrective action will be taken and tho is responsible for taking the corrective action.

Refer to Section 8.0 of WHC-EP-0536.

4.9 Periodic reports to responsible management shall be prepared on the performance of the emissions measurements program. These reports should include assessment of the quality of the data, results of audits and description of corrective actions.

Refer to Section 9.0 of WHC-EP-0536.

4.10 The quality assurance program should be documented in a quality assurance project plan which should address each of the above requirements. 


\section{WHC-EP-0466-1}

The quality assurance program addressing stack 296-A-22 will be documented in a future QAPJP.

\subsubsection{Summary of Gaseous Effluent Sampling/Monitoring Deficiencies}

\subsubsection{Vessel Vent (296-A-22)}

Based on federal regulations, referenced guidelines, and applicable DOE orders, the following deficiencies are noted with the 242-A Evaporator Vessel Vent stack (296-A-22):

- "Frequent or continuous" flow rate measurement is required, rather than "periodic", because the flow rate varies by more than 10 percent.

- Neither stack temperature, stack static pressure, atmospheric pressure, stack moisture content, nor stack gas density, all necessary variables for the accurate calculation of volumetric flow rate, are measured or determined in the current stack flow measurement procedure.

- Neither pretest leak checks (recommended) nor post test leak checks (required) are accomplished in the current stack flow measurement procedure.

- The calculation of volumetric flow rate, as presented in 40 CFR, Part 60, Appendix A, Method 2, is currently not conducted. Corrections are not made for temperature, pressure, or probe calibration coefficients.

- The minimum required number of velocity measurement traverses is not met.

- Velocity traverses are not currently conducted on two perpendicular diameters.

- The verification of the presence or absence of cyclonic flow at the measurement site has not been made.

- Particle size studies have not been completed.

\subsubsection{Building Vent (296-A-21)}

Based on federal regulations, referenced guidelines, and applicable DOE orders, the following deficiencies are noted with the 242-A Evaporator Building Vent stack (296-A-21):

- "Frequent or continuous" flow rate measurement is required, rather than "periodic", because the flow rate varies by more than 10 percent. 
- Neither stack temperature, stack static pressure, atmospheric pressure, stack moisture content, nor stack gas density, a 11 necessary variables for the accurate calculation of volumetric flow rate, are measured or determined in the current stack flow measurement procedure.

- Neither pretest leak checks (recommended) nor post test leak checks (required) are accomplished in the current stack flow measurement procedure.

- The calculation of volumetric flow rate, as presented in 40 CFR, Part 60, Appendix A, Method 2, is currently not conducted. Corrections are not made for temperature, pressure, or probe calibration coefficients.

- The minimum required number of velocity measurement traverses is not met.

- Velocity traverses are not currently conducted on two perpendicular diameters.

- The velocity measurement location is noncompliant.

- The verification of the presence or absence of cyclonic flow at the measurement site has not been made.

- The sample probe location requirements are not met.

- $\quad$ Probe nozzles are not tapered at $30^{\circ}$ as specified in DOE orders.

- The sampler probe is not designed to withdraw an isokinetic sample.

- Particle size studies have not been completed.

\subsubsection{Regulations Governing Liquid Effluent Strearis}

Regulations governing liquid effluents at the Hanford Site are described in Section 3.4 of Chapter 3. The sampling and monitoring design criteria based on these regulations are listed in Section 6.2.2 of Chapter 6 .

\subsubsection{Liquid Streams Sampling/Monitoring Compliance Assessment}

\subsubsection{Cooling Water Monitoring Compliance Assessment}

The used raw-water stream monitoring system serves the purpose of determining whether the stream has come into contact with dangerous waste sources in the 242-A Evaporator process. The 242-A Evaporator condensers are designed and operated to ensure that the cooling water within the condenser tubes is at a greater pressure than the waste constituents being condensed. Therefore, contamination is unlikely. Shutdown of the 242-A Evaporator is required if radiation exceeds a specified level. A high radiation reading on the cooling water stream is not anticipated and no diversion capability is 
directly associated with this monitor. The used raw-water system has no diversion capabilities because the potential for contamination is low. The used raw water EMS meets the required criteria siecified in Section 6.2.2.

\subsubsection{Steam Condensate Monitoring Compliance Assessment}

The steam condensate EMS serves the purpose of determiring whether the stream has come into contact with dangerous waste sources in the 242-A Evaporator process. The 242-A Evaporator is designed and operated to ensure that in any areas where steam may be contaminated by dangerous waste constituents the steam is at a greater pressure than these constituents. Therefore, contamination is unlikely. The steam condensate EMS meets tive required criteria specified in Section 6.2.2.

\subsubsection{Miscellaneous Assessment/Comments}

Two additional assessments/comments are made here.

The first assessment/comment is on the sample probes in the stacks. The Generic Sampling/Monitoring criteria specifies that sample extraction probes shall be flange mounted to the stack to facilitate periodic removal, inspection, and cleaning activities (see Section 6.2.1.1). The probes are designed this way, but it could not be determined if the probes/nozzles are ever cleaned. Obviously, dirty probes/nozzles would hinder reliable sampling results. It is hereby recommended that a procedure be developed and implemented to accomplish this.

The final comment is on the source-term characterization. Because sufficient characterization of the waste in the 200 Area Tank Farms did not exist at the time this FEMP was developed, several referenced sources were used to derive a conservatively appropriate source term. This source term may vary from others (i.e, that presericed in the safety analysis report, the dangerous waste permit application). An attempt is currently underway to develors a consistent source term, but the general problem lies in the fact that there is not sufficient characterization of the waste within the tank farms to determine it accurately. Sufficient characterization has noi been accomplished in the past because of a lack of waste analysis plans. Waste analysis plans have now been developed, but have not been fully implemented.

\subsection{EXEMPTIONS}

RL's :nvironmental Restoration Division has submitted a request for approval of the existing radioactive air emission systems (including flow moasurement, sample collection, and sample analysis) as an alternative measurement method. This request was subsequently denied because of a lack of information (refer to letter June 3, 1991, from Gary 0'Neal to E. A. Bracken (EPA 1991a) 


\subsection{SYSTEA UPGRADES REQUIRED FOR COMPLIANCE}

To bring the 242-A Evaporator into compliance with the established criteria would require a redesign and relocation of the building ventilation sampling probe. Also, if effluent measuring is to be continued using the vent and balance procedure (reference Sections 14.1.1.1 and 14.1.2.1), a port must be placed on the stack to allow proper readings, and the method used may require modification, or at least approval from EPA. Currently, the flow measurement procedure is undergoing a complete rewrite to come into compliance with methods specified in the federal regulations.

Because flow rate within the stacks is variable, a continuous effluent flow-measuring device with stack flow totalizing capabilities should be placed in each stack. It is recommended, to maintain isokinetic sampling conditions, that automatic air-flow feedback control systems that adjust sampler flow by continuously measuring effluent flow be configured in the current sampling/monitoring systems. With systems such as these in place, only periodic (annual) confirmatory manual flow measurement would be required and the accuracy of the sampling/monitoring systems would be greatly enhanced. 
WHC-EP-0466-1

This page intentionally left blank. 


\subsection{SUMMARY AND CONCLUSIONS}

This document was developed because the calculated, potential offsite doses for the 242-A Evaporator Vessel Vent Stack and Building Vent Stack exceed $0.1 \mathrm{mrem} / \mathrm{yr}$. These values are presented in Tables 4-2 and 4-5. Consequently, an evaluation has been made within this document as to the adequacy of the sampling and monitoring systems for effluents of the facility.

The effluents covered were the following:

- Airborne vessel vent stream

- Airborne building ventilation stream

- Liquid steam condensate stream

- Liquid cooling water stream.

In general, all the sampling and monitoring systems are assessed as being adequate except for the building ventilation stack system and vessel vent stack system. 
WHC-EP-0466-1

This page intentionally left blank. 


\subsection{ATTACHMENTS}

\subsection{REFERENCES}

AEC, 1977, "Instrumentation Arrangement Elevations and Details," Drawing No. H-2-69316, Atomic Energy Commission.

ANSI, 1966, Practice for Occupational Radiation Exposure Records Systems ANSI N13.6 - 1966, American National Standards Institute, New York, New York.

ANSI, 1969, Guide to Sampling Airborne Radioactive Materials in Nuclear Facilities, ANSI N13.1 - 1969, American National Standards Institute, New York, New York.

ANSI, 1974, Specifications and Performance of On-Site Instrumentation for Continuously Monitoring Radioactivity in Effluents, ANSI N42.18-1974, American National Standards Institute, New York, New York.

ANSI, 1980, Performance Criteria for Instrumentation Used for Inplant Plutonium Monitoring, ANSI N317-1980, American National Standards Institute, New York, New York.

ARHCO, 1974, Procurement Specification for In-line Radiation Monitor System Building 242-A - Project B-100, B-100-P7, 242-A Evaporator-Crystallizer Facilities, Atlantic Richfield Hanford Company, Richland, Washington.

Beres, D. A., 1990, The Clean Air Act Assessment Package - 1988 (CAP-88). $A$ Dose and Risk Assessment Methodology for Radionuclide Emissions to Air, Vols. 1-3, U.S. Environmental Protection Agency, Washington, D.C.

Clean Air Act of 1977, as amended, 41 USC 7401, et seq.

Clean Water Act of 1977, as amended, 33 USC 1251, et seq.

Comprehensive Environmental Response, Compensation, and Liability Act of 1980 (CERCLA), 42 USC 9601, et seq.

DOE, 1981, Environmental Protection, Safety, and Health Protection Information Reporting Requirements, DOE Order 5484.1, U.S. Department of Energy, Washington, D.C.

DOE, 1988a, General Environmental Protection Program, DOE Order 5400.1, U.S. Department of Energy, Washington, D.C.

DOE, 1990a, Radioactive Waste Management, DOE Order 5820.2A, U.S. Department of Energy, Washington, D.C.

DOE, 1990b, Radiation Protection of the Public and the Environment, DOE Order 5400.5, U.S. Department of Energy, Washington, D.C. 
DOE, 1991a, Environmental Regulatory Guide for Radiological Effluent Monitoring and Environmental Surveillance, DOE/EH-0173T, U.S. Department of Energy, Washington, D.C.

DOE, 1991b, Quality Assurance, DOE Order 5700.6C, U.S. Department of Energy, Washington, D.C.

DOE-RL, 1990, 242-A Evaporator Dangerous Waste Permit Application, DOE/RL-90-42, U.S. Department of Energy Field Office, Richiand, Washington.

DOE-RL, 1991, Calendar Year 1990 Air Emissions Report for the Hanford Site, DOE/RL-91-10, U.S. Department of Energy-Richland Operations Office, Richland, Washington.

DOE-RL, 1992, Radionuclide Air Emissions Report for the Hanford Site, DOE/RL-92-30, U.S. Department of Energy-Richland Operations Office, Richland, Washington.

Ecology, 1990a, "Dangerous Waste Regulations," Washington Administrative Code, Chapter 173-303, as amended, Washington State Department of Ecology, 0lympia, Washington.

Ecology, 1990b, "Records, Monitoring, and Reporting," Washington Administrative Code, WAC 173-400-105, as amended, Washington State Department of Ecology, 01ympia, Washington.

Ecology, 1990c, "General Regulations of Air Pollution," Washington Administrative Code, Chapter $173-400$, as amended, Washington State Department of Ecology, 01ympia, Washington.

Ecology, 1990d, "National Pollutant Discharge Elimination System Permit Program," Washington Administrative Code, Chapter 173-220, Washington State Department of Ecology, Olympia, Washington.

Ecology, 1990e, "State Waste Discharge Permit Program," Washington Administrative Code, Chapter 173-216, as amended, Washington State Department of Ecology, O1ympia, Washington.

Ecology, 1990f, "Radiation Protection Air Emissions," Washington Administrative Code, Chapter 246-247, as amended, Washington State Department of Ecology, Olympia, Washington.

Ecology, 1990g, "Ambient Radionuclides," Washington Administrative Code, Chapter 173-480, as amended, Washington State Department of Ecology, 01 ympia, Washington.

Ecology, et al. 1991, Hanford Federal Facility Agreement and Consent Order, Volumes 1 and 2, Washington State Department of Ecology, U.S. Environmental Protection Agency, and U.S. Department of Energy, Olympia, Washington. 
EPA, 1986a, Test Methods for Evaluating Solid Waste: Physical/Chemical

Methods, SW-846, Third Edition, EPA Standard Method 0030, "Volatile Organic Sampling Train," U.S. Environmental Protection Agency, Office of Solid Waste, and Emergency Response, Washington, D.C.

EPA, 1986b, Reference Methodologies, Title 40, Code of Federal Regulations, Part 60, Appendix A, U.S. Environmental Protection Agency, Washington, D.C.

EPA, 1990, Quality Assurance Methods, Title 40, Code of Federal Regulations, Part 60, and Appendix A, "Reference Methodologies," U.S. Environmental Protection Agency, Washington, D.C.

EPA, 1991a, Letter from Gary 0'Neal, Director Air Toxics Division of U.S. Environmental Protection Agency to E. A. Bracken, Director, Environmental Restoration Division, U.S. Department of Energy, June 3, 1991.

EPA, 1991b, "National Emissions Standards for Hazardous Air Pollutants" (NESHAPS), as amended, Title 40, Code of Federal Regulations, Part 61, U.S. Environmental Protection Agency, Washington, D.C.

EPA, 1991c, "Designation, Reportable Quantities, and Notification", Title 40, Code of Federal Regulations, Part 302, as amended, U.S. Environmental Protection Agency, Washington, D.C.

EPA, 1991d, "Environmental Radiation Protection Standards for Management and Disposal of Spent Nuclear Fuel, High-Level and Transuranic Radioactive Waste," Title 40, Code of Federal Regulations, Part 191, U.S. Environmental Protection Agency, Washington, D.C.

EPA, 199le, "Health and Environmental Protection Standards for Uranium and Thorium Mill Tailings," Title 40, Code of Federal Regulations, Part 192, as amended, U.S. Environmental Protection Agency, Washington, D.C.

EPA, 1991f, "Approval and Promulgation of Implementation Plans," Title 40, Code of Federal Regulations, Part 52, as amended, U.S. Environmental Protection Agency, Washington, D.C.

EPA, 1991g, "National Interim Primary Drinking Water Regulations" (Safe Drinking Water Act), EPA-570/9-76/003, Title 40, Code of Federal Regulations, Part 141, U.S. Environmental Protection Agency, Washington, D.C.

EPA, 1991i, "Identification and Listing of Hazardous Waste," Title 40, Code of Federal Regulations, Part 261, as amended, U.S. Environmental

Protection Agency, Washington, D.C.

FR 1990, "Final Rule, Air Emission Standards Finalized for Hazardous Waste TSD Facilities," Federal Register, Vol. 55, No. 120, Thursday, June 21, 1990, Rules and Regulations 25455, U.S. Environmental Protection Agency, Washington, D.C. 
Huckfeldt, C. R., 1992, Quarterly Environmental Radiological Survey Summary Second Quarter 1991 100, 200, 300, and 600 Areas, WHC-SP-0665-02, Westinghouse Hanford Company, Richland, Washington.

ICRP, 1979, Limits on Intakes of Radionuclides by Workers, Publication 30 , International Commission on Radiological Protection, Elmsford, New York, July 1979.

Moss, S. S., 1990, Quality Assurance Program Plan for the Chemical Analysis of Environmental Samples, WHC-SD-CP-QAPP-003, Westinghouse Hanford Company, Richland, Washington.

Napier, B. A., R. A. Peloquin, D. L. Strenge, and J. V. Ramsdell, 1988, GENII - The Hanford Environmental Radiation Dosimetry Software System, PNL-6584, Vols. 1-3, Pacific Northwest Laboratory, Richland, Washington.

Nuclear Waste Policy Act of 1982, 42 USC 10101, et seq.

PNL/WHC, 1989, "Memorandum of Understanding," Pacific Northwest Laboratory and West inghouse Hanford Company, July, 1989, Richland, Washington.

Resource Conservation and Recovery Act of 1976, as amended, 42 USC 6901, et seq.

RHO, 1978a, Procurement Specification for Alpha Air Sampler/Monitor, HWS-10192, Rockwell Hanford Operations, Richland, Washington.

RHO, 1978b, Procurement Specification for Beta-Gamma Particulate Air Monitor, HWS-10193, Rockwe11 Hanford Operations, Richland, Washington.

RHO, 1980a, 200 Area Stack Sampler-Monitor Systems Upgrade: Generic Systems Applications, RHO-CD-1092, Rockwell Hanford Operations, Richland, Washington.

RHO, 1980b, Installation Criteria for the Generic Stack Monitoring System, RHO-MA-241, Rockwe11 Hanford Operations, Richland, Washington.

RHO, 1981, Test Procedure for Generic Design Exhaust Stack Sampler/Monitor Application to 200 Area Exhaust Stacks, Acceptance Test Procedure ATP-G-999-00010, Rev A-0, Rockwell Hanford Operations, Richland, Washington.

RHO, 1981a, Hanford Site Drawings $\mathrm{H}-2-92486$ through $\mathrm{H}-2-92504$, Rockwell Hanford Operations, Richland, Washington.

RHO, 1984, FY 1985200 Area Stack Sampler/Monitor Systems Upgrade, SD-WM-CR-016, Rockwe11 Hanford Operations, Richland, Washington.

RHO, 1985, Liquid Effluent Monitor Calibration for the 242-A Evaporator, SD-SQA-TI-003, Rockwell Hanford Operations, Richland, Washington.

RHO, 1986, Rockwell Hanford Operations Environmental Surveillance Annual Report: Calendar Year 1985, RHO-HS-SR-85-13P, Rockwell Hanford Operations, Richland, Washington. 
RHO, 1987a, Radioactivity in Gaseous Waste Discharged from the Separations Facilities During 1986, RHO-HS-SR-86-2-4QGAS P, Rockwe 11 Hanford Operations, Richland, Washington.

RHO, 1987b, Rockwell Hanford Operations Environmental Surveillance Annual Report: Calendar Year 1986, RHO-HS-SR-86-13P, Rockwel1 Hanford Operations, Richland, Washington.

SARA, 1986, Superfund Amendments and Reauthorization Act of 1986 (SARA). 42 USC 11001, et seq.

Svancara, G. B., 1991, Analytical Chemistry Services Laboratories Quality Assurance Plan, WHC-SD-CP-QAPP-001-ENG, Rev. 0, West inghouse Hanford Company, Richland, Washington.

UBC, 1991, Uniform Building Code, International Conference of Building officials, Whittier, California.

WAC, 1989, "Dangerous Waste Regulations," Washington Administrative Code, 173-303, Washington State Department of Ecology, Uiympia, Washington.

WAC, 1990a, "National Pollutant Discharge Elimination System Permit Program," Washington Administrative Code, 173-220, Washington State Department of Ecology, 0lympia, Washington.

WAC, 1990b, "State Waste Discharge Permit Program," Washington Administrative Code, 173-216, Washington State Department of Ecology, 01ympia, Washington.

WAC, 1991, "General Regulations for Air Pollution Sources," Washington Administrative Code, 173-400, Washington State Department of Ecology, Olympia, Washington.

Weast, 1976, The Handbook of Chemistry and Physics, 57 Edition, CRC Press, Inc., Cleveland, Ohio.

WHC Maintenance Engineering Services Procedures, Westinghouse Hanford Company, Richland, Washington.

- PSCP-3-002, "Eberline Beta Air Monitor, Models AMS-3, AMS-3A, And 700300."

- PSCP-3-003," Eberl ine Alpha-4, -5, and 5A."

- PSCP-4-007, "Rockwe11 Type Gas Meter."

- PSCP-4-091, "Pressure and Vacuum Gauges."

- PSCP-6-029, "Chem-. Tec Adjustable Flow Switch Model 500."

- PSCP-7-001, "Air Rotameter."

- PSCP-7-001, Rev 1, 1989, "Calibration Procedure, Air Rotameter."

WHC Controlled Manuals, Westinghouse Hanford Company, Richland, Washington.

- WHC-CM-1-3, Management Requirements and Procedures, as amended.

- WHC-CM-4-12, Health Physics Practices Manual, as amended.

- WHC-CM-5-7, Tank Farms, Grout, and Solid Waste Management Administration Manual. 
WHC, 1988a, 242-A Evaporator Safety Analysis Report, WHC-SD-WM-SAR-023, Westinghouse Hanford Company, Richland, Washington.

WHC 1988b, Operating Specifications for the Operation of the 242-A EvaporatorCrystallizer, OSD-T-151-00012, Westinghouse Hanford Company, Richland, Washington.

WHC, 1988c, Operational Environmental Monitoring, WHC-CM-7-4, Westinghouse Hanford Company, Richland, Washington.

WHC, 1988d, Westinghouse Hanford Company Effluent Discharges and Solid Waste Management Report for 1987: 200/600/1100 Areas, WHC-EP-0141, Westinghouse Hanford Company, Richland, Washington.

WHC, 1988e, Westinghouse Hanford Company Environmental Surveillance Annual Report: 200/600 Areas, Calendar Year 1987, WHC-EP-0145, Westinghouse Hanford Company, Richland, Washington.

WHC, 1989a, Airflow Capacity and Distribution Tests, Maintenance Engineering Services Maintenance Procedure, 7-GN-56, Rev 1, Westinghouse Hanford, Richland, Washington.

WHC, 1989b, Hazardous Waste Management, WHC-CM-5-16, Westinghouse Hanford Company, Richland, Washington.

WHC, 1989c, Internal Memo 13331-89-482; from Waste Concentration Process Engineering Unit; dated December 13, 1989; subject: Nitric Acid Released During 242-A Evaporator Flush.

WHC, 1989d, Internal Memo 12715-ASL-136; dated Apri1 6, 1989; from Analytical Systems Laboratories to C. M. Winkler; Tritium Content of the 242-A Evaporator Stack Gases.

WHC, 1989e, Westinghouse Hanford Company Effluent Discharges and Solid Waste Management Report for 1988: 200/600 Areas, WHC-EP-0141-1, Westinghouse Hanford Company, Richland, Washington.

WHC, 1989f, Westinghouse Hanford Company Quality Assurance Manual, WHC-CM-4-2, Westinghouse Hanford Company, Richland, Washington.

WHC, 1990a, Westinghouse Hanford Company Effluent Discharges and Solid Waste Management Report: 200/600 Areas, Calendar Year 1989, WHC-EP-0141-2, Westinghouse Hanford Company, Richland, Washington.

WHC, 1990b, 242-A Evaporator Cooling Water Stream-Specific Report, WHC-EP-0342, Addendum 21, Westinghouse Hanford Company, Richland, Washington.

WHC, 1990C, 242-A Evaporator Process Condensate Stream-Specific Report, WHC-EP-0342, Addendum 15, Westinghouse Hanford Company, Richland, Washington.

WHC, 1990d, 242-A Evaporator Steam Condensate Stream-Specific Report, WHC-EP-0342, Addendum 26, Westinghouse Hanford Company, Richland. 
WHC, 1990e, Functional Design Criteria for the 242-A Evaporator and Purex Plant Condensate Treatment Facility, WHC-SD-C018-FDC-001, Rev 1, Westinghouse Kanford Company, Richland, Washington.

WHC, 1990f, Internal Memo 1331-90-012; Dated January 8, 1990; From Waste Concentration Process Engineering; Subject: Notification of Continuous Release of Ammonia and Ammonia Hydroxide Hazardous Substances.

WHC, 1990g, Radiological Design Criteria, Section 10.0, REV 0, Sampling and Monitoring, WHC-CM-4-9, Westinghouse Hanford Company, Richland, Washington.

WHC, 1990h, Sample/Fill/Drain 242-A Steam Condensate, POP-T0-630-040, Westinghouse Hanford Company, Richland, Washington.

WHC, 1990i, Technical Basis Document, LERF Inventory Control OSR, WHC-SD-WM-TI-448, Rev 0, Westinghouse Hanford Company, Richiand, Washington.

WHC, 1991a, A Guide for Preparing Hanford Facility Effluent Monitoring Plans, WHC-EP-0438-1, Westinghouse Hanford Company, Richland, Washington.

WHC, 1991b, 242-A Evaporator Hazard Classification, WHC-SD-WM-PSE-008, Westinghouse Hanford Company, Richland, Washington.

WHC, 1991c, Internal Memo 76400-91-028, Rev 1, from Tank Farm Process Engineering, dated August 16, 1991; Subject: 242-A Evaporator Safety Analysis Report Bounding Source Term.

WHC, 1991d, Management Plan for Facility Effluent Monitoring Plan Activities, WHC-EP-0491, Westinghouse Hanford Company, Richland, Washington.

WHC, 1991e, Internal Memo 29510-091-002; Dated March 1, 1991; From Evaporator Restart SAR Development; Subject: Normal Operating Source Term For The 242-A Evaporator.

WHC, 1991f, Internal Memo 86132-91-MOA-006; Dated January 22, 1991; From Effluent Technology; Subject: Re-submittal of Data for Inclusion in the W-105 Functional Design Criteria.

WHC, 1991g, 242-A Evaporator Comparison With 40 CFR 61, Subpart H, and Other Referenced Guidelines For Stack 296-A-22, WHC-EP-0542, Westinghouse Hanford Company, Richland, Washington.

WHC, 1991h, Quality Assurance Program Plan for Radionuclide Airborne Emissions Monitoring, WHC-EP-0536, Westinghouse Hanford Company, Richland, Washington.

WHC, 1991i, Facility Effluent Monitoring Plan for the 222-S Laboratory, WHC-EP-0480, Westinghouse Hanford Company, Richland, Washington.

WHC, 1991j, Environmental Releases for Calendar Year 1990, WHC-EP-0527, Westinghouse Hanford Company, Richland, Washington. 
WHC, 1992a, 242-A Evaporator Steam Condensate Sampling and Analysis Plan, WHC-SD-WM-EV-079, REV 1, Westinghouse Hanford Company, Richland, Washington.

WHC, 1992b, 242-A Evaporator Cooling Water Sampling and Analysis Plan, WHC-SD-WM-EV-078, REV 1, Westinghouse Hanford Company, Richland, Washington.

WHC, 1992c, Liquid Effluent Sampling Quality Assurance Project Plan, WHC-SD-WM-QAPP-011 REV.1, West inghouse Hanford Company, Richland, Washington.

WHC, 1992d, Operational Health Physics Practices Manual, WHC-CM-4-12, RELEASE 25, Westinghouse Hanford Company, Richland, Washington.

WHC, 1992e, Sample Cooling Water from 242-A Via Receiver Carboy RC-2, T0-630-060, Westinghouse Hanford Company.

WHC, 1992f, Quality Assurance Project Plan for Facility Effluent Monitoring Plan Activities, WHC-EP-0446, Rev. 1, Westinghouse Hanford Company, Richland, Washington.

WHC, 1992g, Health Physics Procedures, WHC-IP-0692, Rev. 4, Westinghouse Hanford Company, Richland, Washington.

WHC, 1992h, Management Requirements and Procedures Manual, WHC-CM-1-3, Westinghouse Hanford Company, Richland, Washington.

WHC, 1992i, Environmental Compliance Manual, WHC-CM-7-5, Westinghouse Hanford Company, Richland, Washington.

WHC, 1992j, Management Policies, WHC-CM-1-1, Westinghouse Hanford Company, Richland, Washington.

WHC, 1992k, Environmental Releases for Calendar Year 1991, WHC-EP-0527-1, Westinghouse Hanford Company, Richland, Washington

WHC, 19921, 242-A Evaporator Comparison with 40 CFR 61, Subpart H, and Other Referenced Guidel ines for Stack 296-A-22, WHC-EP-0542, Westinghouse Hanford Company, Richland, Washington.

WHC, 1992m, Quality Assurance Project Plan for Radioactive Airborne Emissions Data Compilation and Reporting, WHC-EP-0528, Westinghouse Hanford Company, Richland, Washington. 
WHC-EP-0466-1

\section{DISTRIBUTION}

\section{Number of Copies}

OFFSITE

3

Westinghouse Idaho Nuclear Company

PO Box 4000

Idaho Falls, Idaho 83403

K. Kouri

\section{ONSITE}

7

U.S. Department of Energy

Field Office, Richland

G. M. Bell

R. F. Brich

S. S. Clark

E. B. Dagan

L. A. Huffman

S. D. Stites

Public Reading Room

A5-52

A5-55

A6-55

A5-19

A6-55

A5-19

A1-65

1

Hanford Environmental Health

Foundation

J. J. Maher

B2-75

2

Kaiser Engineers Hanford

B. J. Dixon

E3-33

D. R. Pratt

E3-33

8

Pacific Northwest Laboratory

W. J. Bjorklund

P7-68

T. D. Chikalla

P7-75

G. R. Hoenes

R. E. Jaquish

D. L. Klages

P7-78

$\mathrm{K} 1-30$

A. K. Stalker

P7-68

R. K. Woodruff

P7-60

K6-13

Technical Files

K1-11 
WHC-EP-0466-1

\section{DISTRIBUTION (continued)}

Number of Copies

ONSITE

71 Westinghouse Hanford Company

S. E. Albin

T1-06

R. L. Baker

S4-65

J. A. Bates

B2-19

H. L. Benny

G. T. Berl in

L7-09

J. C. Biagina

LO-18

D. L. Bjorklund

$56-30$

R. J. BIiss

S6-01

W. W. Bowen

B3-04

S. L. Brey

S6-65

T. D. Chikalla

T6-12

G. M. Crummel (5)

P7-75

L. P. Diediker (2)

$\mathrm{R} 1-51$

J. J. Dorian

$\mathrm{T} 1-30$

R. G. Egge

B. G. Erlandson

D. G. Farwick

T. P. Frazier (20)

H6-30

R2-77

H6-20

H4-16

K. A. Gano

$\mathrm{T} 1-30$

J. E. Geary

$\mathrm{X} 0-21$

R. D. Gustavson (5)

S5-14

K. A. Hadley

D. G. Hamrick

R. J. Julian

J. R. Kasper

R. J. Landon

G. J. LeBaron

C. D. Lucas

D. J. McBride

R1-51

R3-56

R1-51

T3-28

R2-50

H6-22

S6-19

X0-35

P. C. Miller

T5-54

G. J. Miskho

N2-04

M. R. Morton

R2-50

J. M. Nickels

R2 $-7 T$

R. J. Nicklas

H6-22

D. E. Rasmussen

R1-43

R. W. Szelmeczka

L4-30

L. W. Vance

D. J. Watson

T4-06

H4-16

X0-41

B. F. Weaver

T3-11

C. D. Woll am

S6-19

Document Processing and Distribution (2)

L8-15

Central Files

L8-04

Information Release Administration (3)

R1-08 

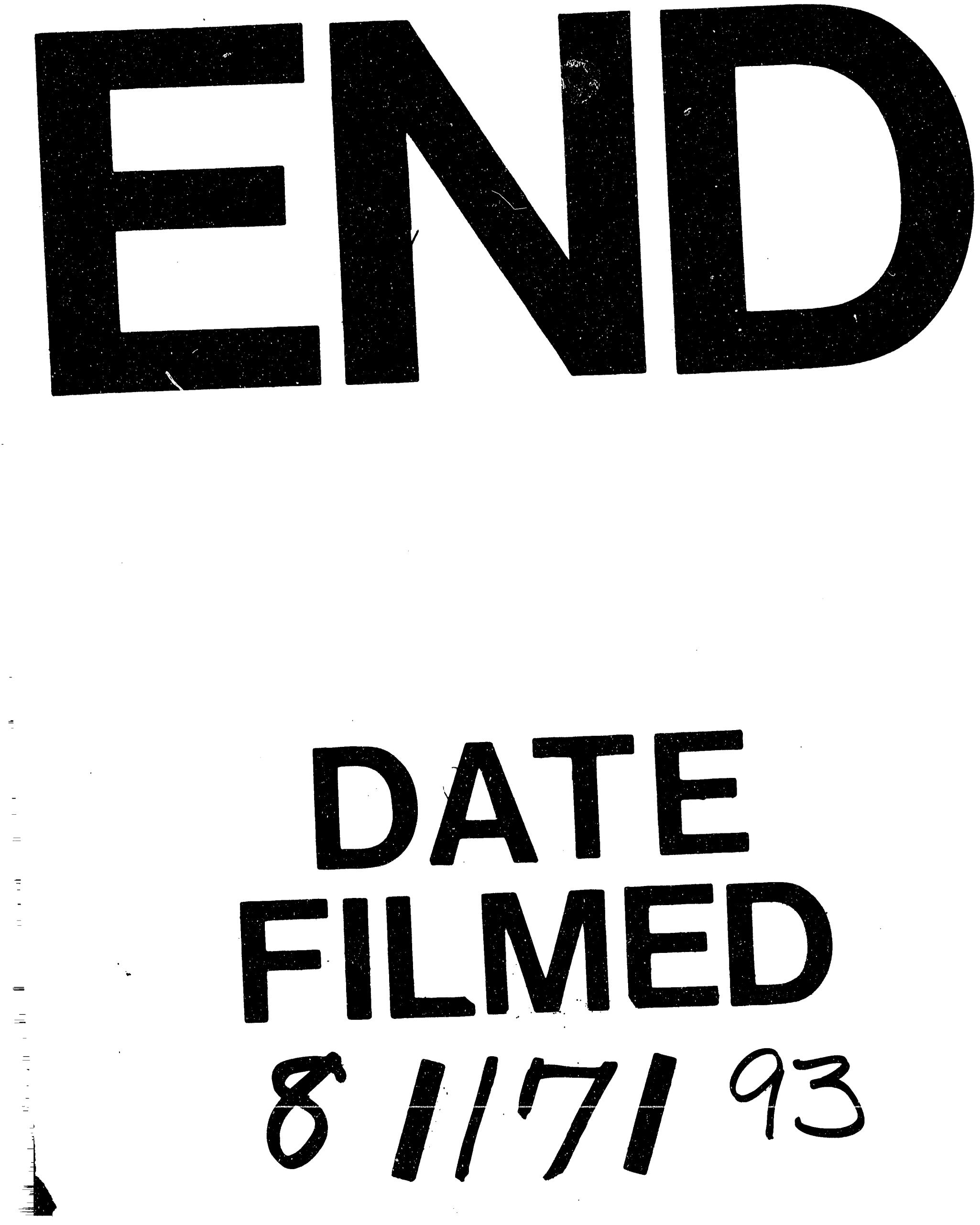
